\title{
WestVirginiaUniversity
}

THE RESEARCH REPOSITORY @ WVU

Graduate Theses, Dissertations, and Problem Reports

2009

\section{Examination of the use of assessment by accredited business schools}

Tracie M. Dodson

West Virginia University

Follow this and additional works at: https://researchrepository.wvu.edu/etd

\section{Recommended Citation}

Dodson, Tracie M., "Examination of the use of assessment by accredited business schools" (2009).

Graduate Theses, Dissertations, and Problem Reports. 2922.

https://researchrepository.wvu.edu/etd/2922

This Dissertation is protected by copyright and/or related rights. It has been brought to you by the The Research Repository @ WVU with permission from the rights-holder(s). You are free to use this Dissertation in any way that is permitted by the copyright and related rights legislation that applies to your use. For other uses you must obtain permission from the rights-holder(s) directly, unless additional rights are indicated by a Creative Commons license in the record and/ or on the work itself. This Dissertation has been accepted for inclusion in WVU Graduate Theses, Dissertations, and Problem Reports collection by an authorized administrator of The Research Repository @ WVU.

For more information, please contact researchrepository@mail.wvu.edu. 


\title{
Examination of the Use of Assessment by
} Accredited Business Schools

Tracie M. Dodson

Dissertation submitted to the College of Human Resources and Education at West Virginia University in partial fulfillment of the requirements for the degree of

\author{
Doctor of Education \\ in \\ Educational Leadership Studies \\ Elizabeth Jones, Ph.D., Chair \\ Jeffrey Godwin, Ph.D. \\ Ernest Goeres, Ph.D. \\ Sarah Selmer, Ph.D. \\ Sam Stack, Ph.D. \\ Richard Walls, Ph.D. \\ Department of Advanced Educational Studies \\ Morgantown, West Virginia
}

2009

Keywords: Assessment; Accreditation; School of Business; Best Practices Copyright 2009 Tracie M. Dodson 


\section{ABSTRACT \\ Examination of the Use of Assessment by \\ Accredited Business Schools}

Tracie M. Dodson

Assessment and accreditation are common topics in the literature of higher education. These two practices can impact an institution's ability to produce high quality students, graduates, and general success as an institution. Outcomes assessment is a method of measuring student learning as a result of the educational process. Accreditation seeks to provide external validation of the quality of a program and ensure that the public and other external constituents are aware of, and can depend on, a certain standard quality level.

In academic business units, there are three accreditation agencies. These organizations include the Association to Advance Collegiate Schools of Business (AACSB International), the Association of Collegiate Business Schools and Programs (ACBSP), and the International Assembly for Collegiate Business Education (IACBE).

Because business schools are increasingly encouraged to obtain accreditation, understanding the use and practice of assessment encouraged by the different accreditation bodies can provide valuable information and help shape future actions and decision making. This study reviewed the assessment practices of business schools, the relationship accreditation plays in their assessment efforts, and the extent that assessment practices vary based on their relationship with an accreditation body. Through this inquiry, a clearer understanding of assessment in accredited business schools was acquired.

The results of the study indicated that business schools are assessing students and are following the best practices of assessment overall. It also indicated that the practice of assessment has a positive relationship with the success of the business school. In comparing accrediting agencies, all agencies indicated that they are assessing students; however, there are statistically significant differences between accreditation bodies in specific practices. 


\section{ACKNOWLEDGEMENTS}

This research could not have been conducted, or completed, without the support of my family. In appreciation for their love and constant support, and for their time and understanding, I would like to acknowledge my husband, JR; my children, Hannah, Abbie, and Collin; my parents, Jim and Cindy; and my grandparents, Gene and Ramona. Words cannot express the level of gratitude and love I have for them.

I have also relied on the time and attention of past and present members of my committee and would like to acknowledge Elizabeth Jones, Ernest Goeres, Richard Walls, Dieter Schaupp, Jon Reed, Sarah Selmer, Sam Stack, and Jeff Godwin. I sincerely appreciate their feedback and willingness to serve as members of my committee. 


\section{TABLE OF CONTENTS}

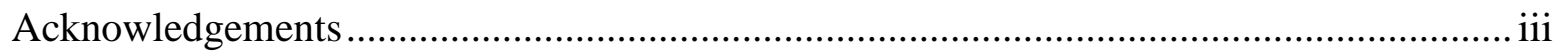

Table of Figures ....................................................................................................... vii

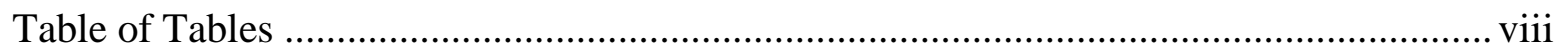

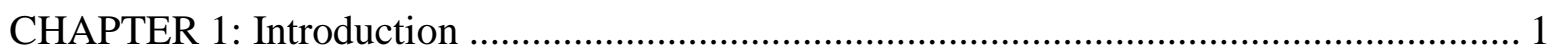

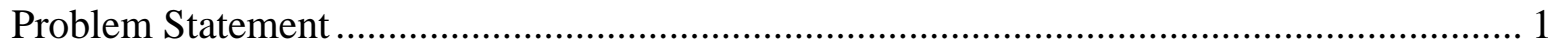

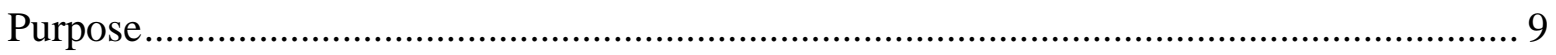

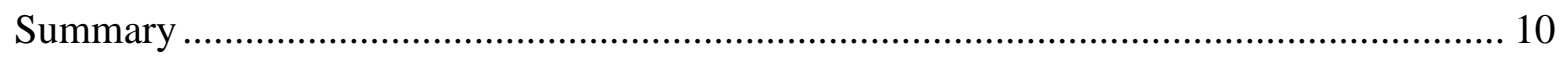

CHAPTER 2: Review of Relevant Literature........................................................... 11

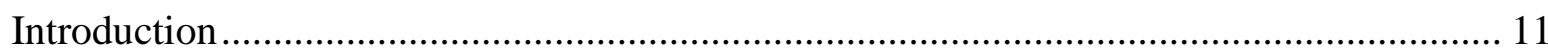

Purposes of Assessment and Learning Outcomes ................................................... 12

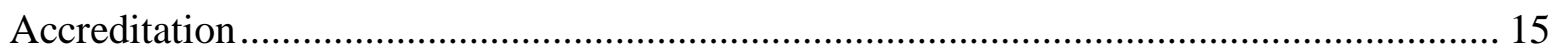

Assessment and Accreditation Connection......................................................... 17

Assessment Principles of Best Practice .................................................................. 19

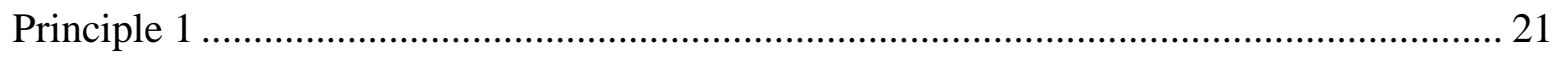

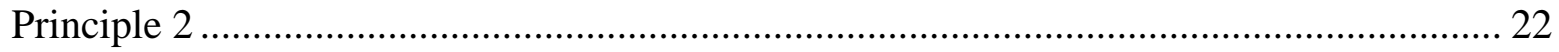

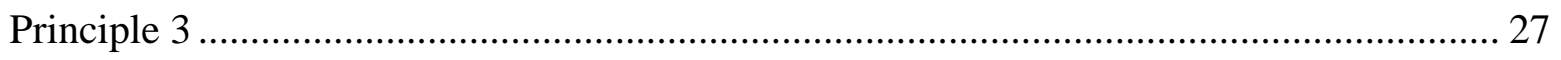

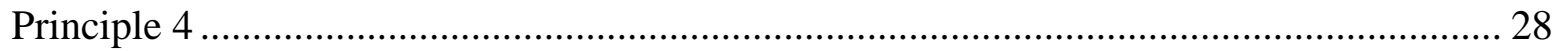

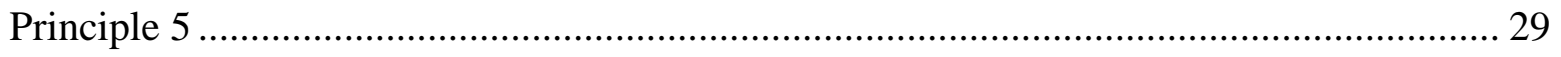

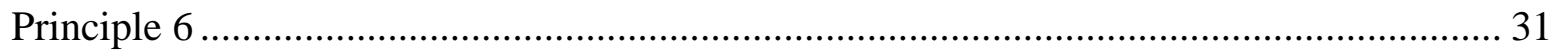

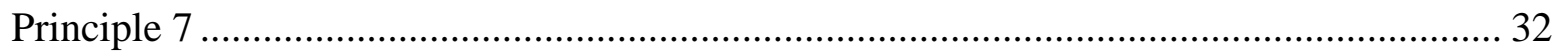

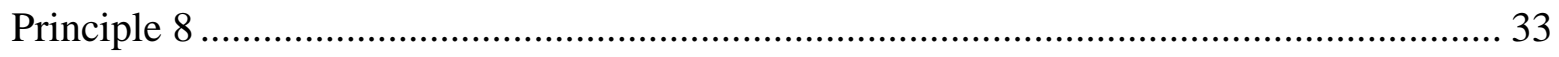

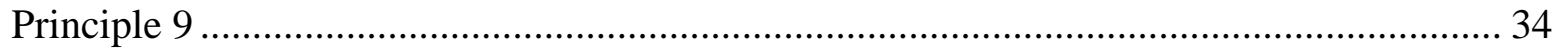




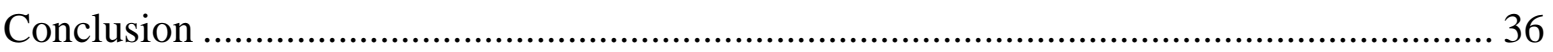

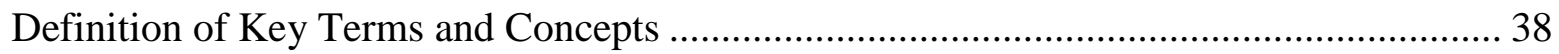

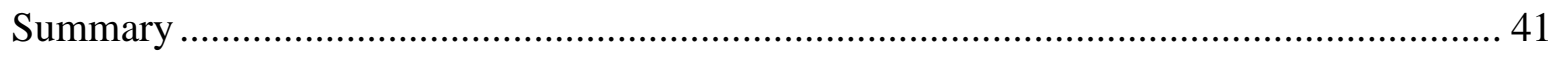

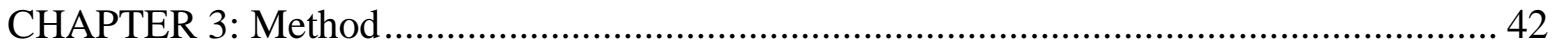

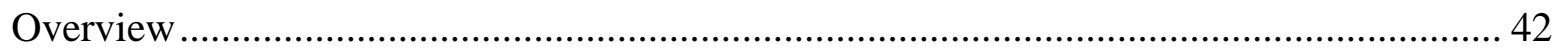

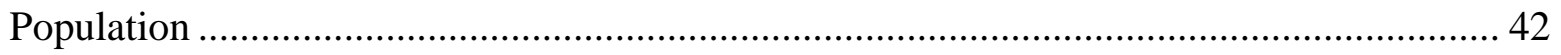

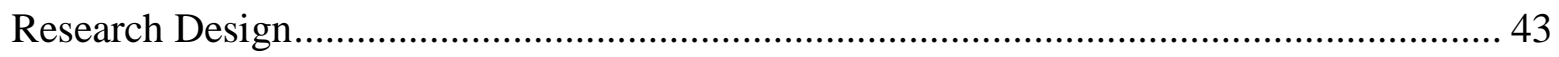

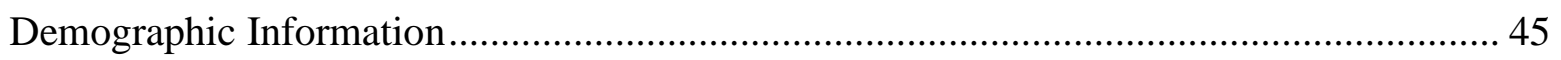

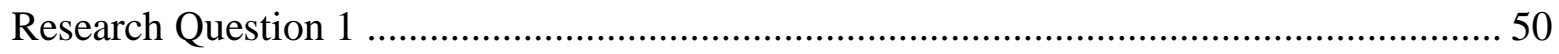

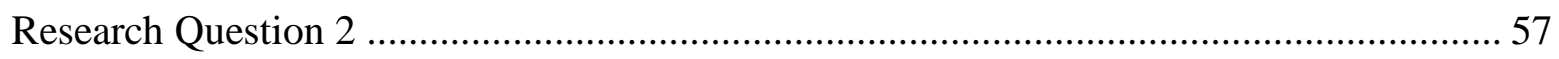

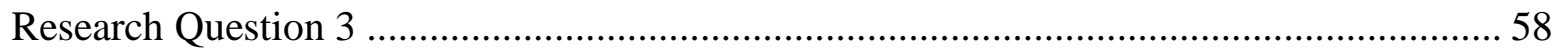

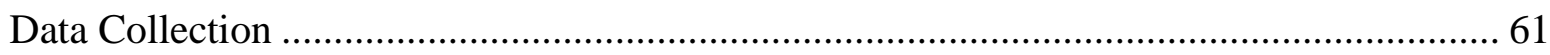

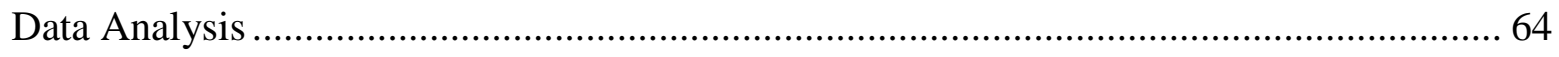

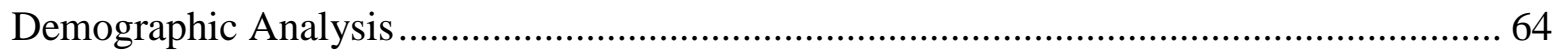

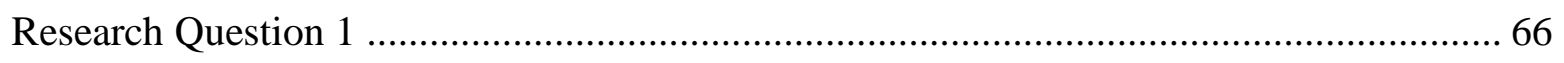

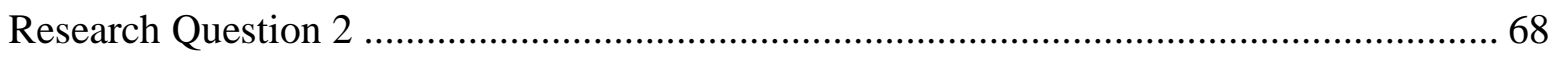

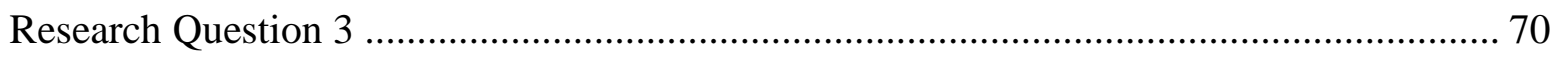

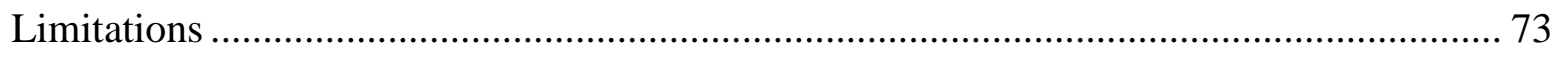

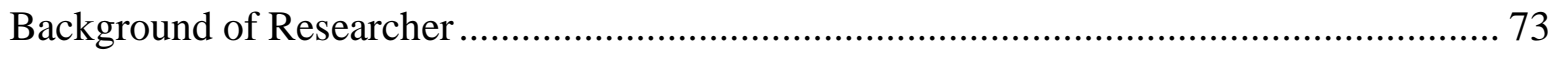

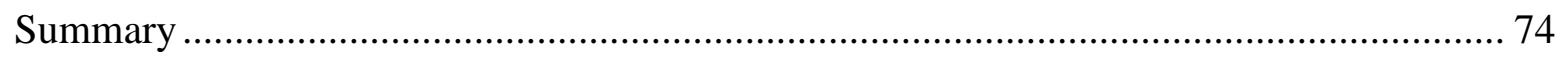

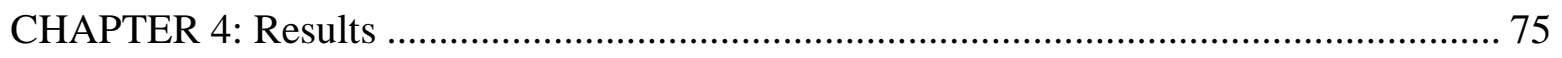

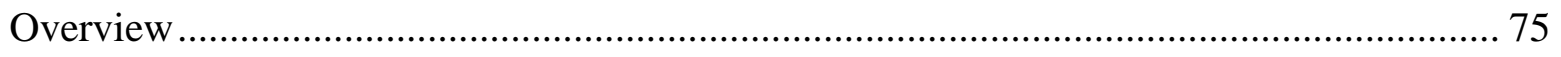

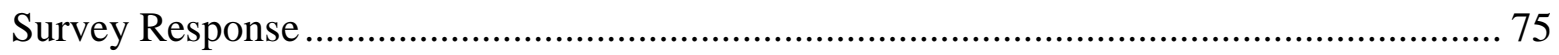




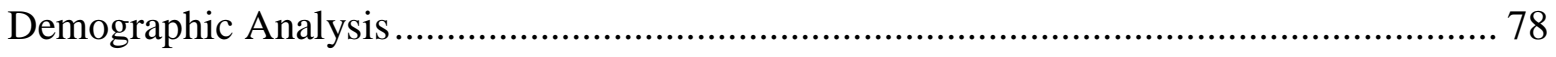

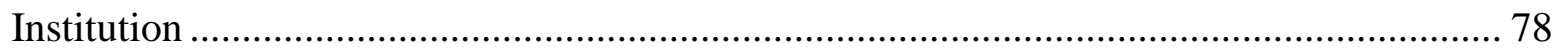

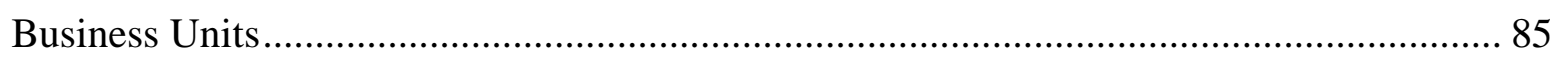

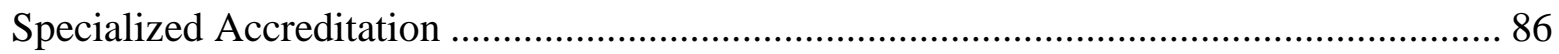

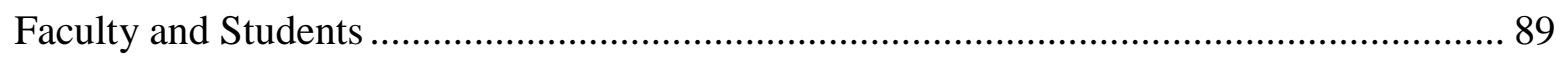

Research Question 1 .................................................................................. 107

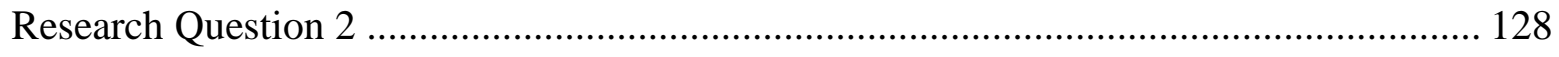

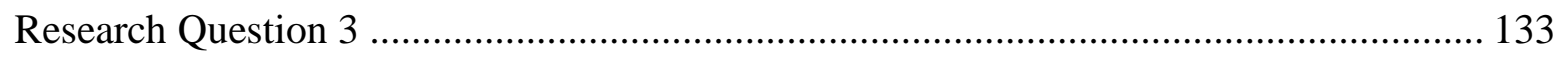

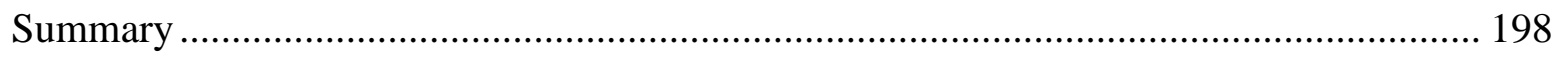

CHAPTER 5: Summary, Conclusions, Recommendations for Practice and

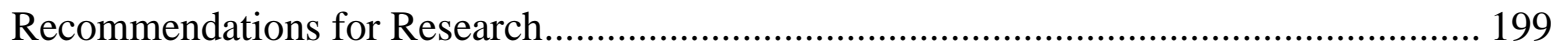

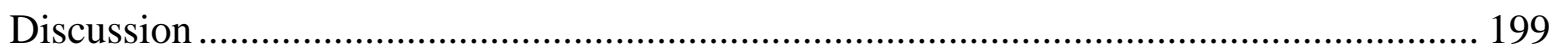

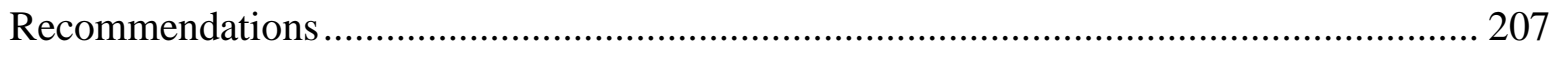

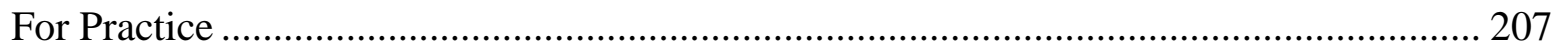

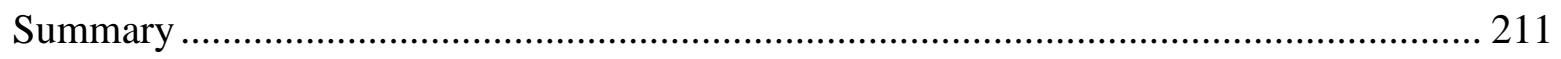

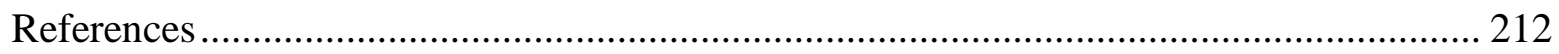

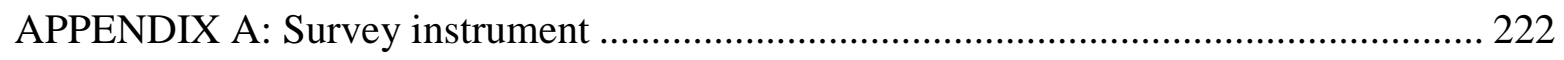

APPENDIX B: Sample pilot Study Letter ............................................................ 227

APPENDIX C: Pilot Survey Interview Questions ................................................ 229

APPENDIX D: Sample Survey Cover Letter ......................................................... 231 


\section{TABLE OF FIGURES}

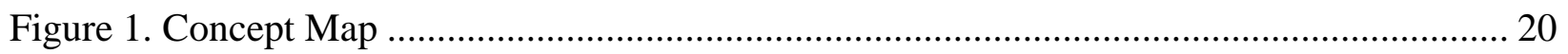

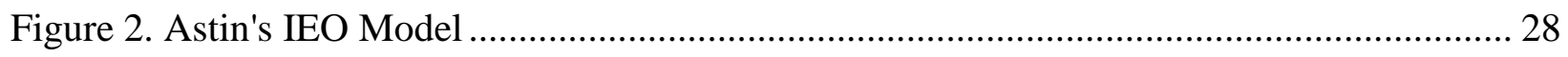

Figure 3. Huba and Freed's Assessment Process........................................................... 30

Figure 4. Regional Accreditation of Respondents ....................................................... 83 


\section{TABLE OF TABLES}

Table 1 Bloom's Taxonomy of Cognitive Objectives .............................................................. 14

Table 2 Middle States Direct and Indirect Assessment Examples ............................................. 26

Table 3 Survey Items by Research Question ........................................................................... 45

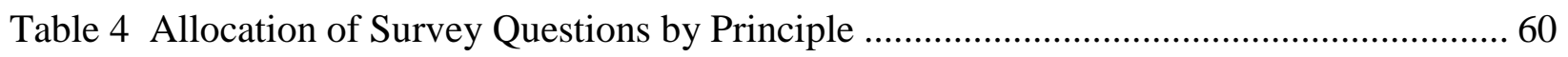

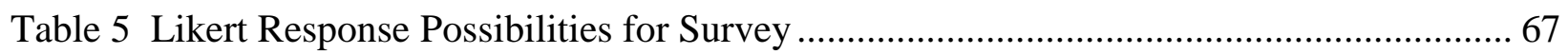

Table 6 Map of Corresponding Components in Correlations ....................................................... 69

Table 7 MANOVA Dependent Variable Question Sets ............................................................. 71

Table 8 All Survey Respondents by Accreditation Group........................................................ 77

Table 9 Business Units Included in Study by Accreditation Group ........................................... 78

Table 10 Frequency of Institution Year Founded by Accreditation ........................................... 78

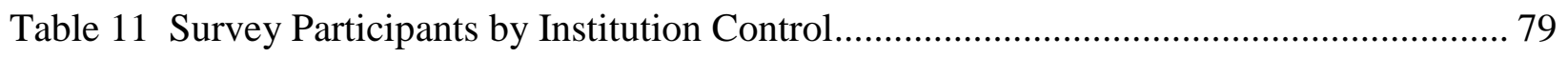

Table 12 Participant Institution Focus ………….............................................................. 80

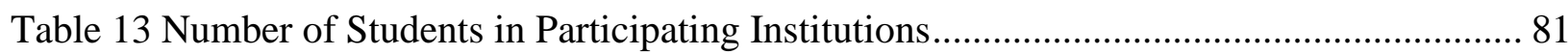

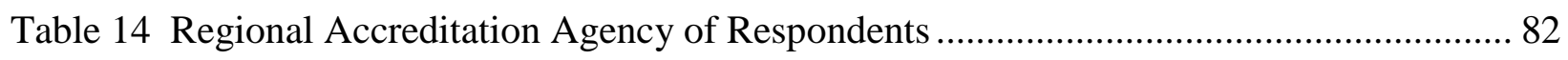

Table 15 Regional Institutional Accreditation Review Date ……………………....................... 84

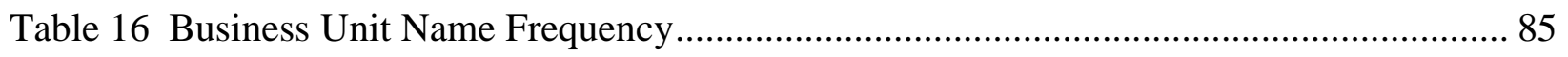

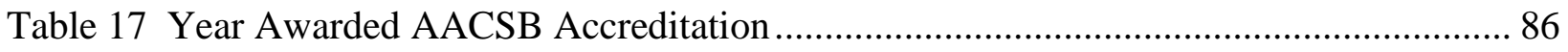

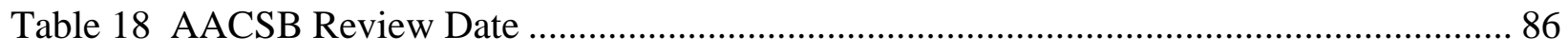

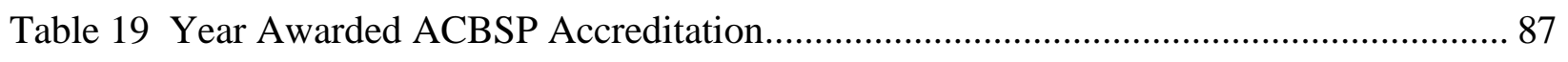

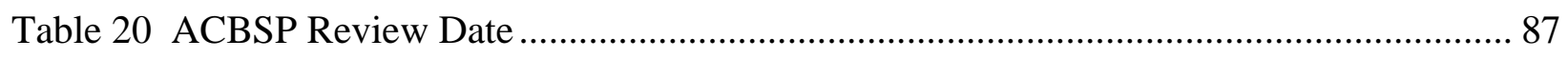

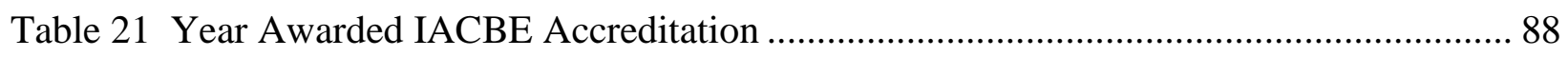

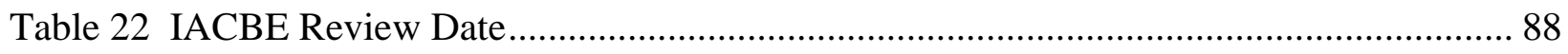


Table 23 Number of Full-Time Faculty Members in Business Units..................................... 90

Table 24 Number of Part Time Faculty Members in Business Units ..................................... 91

Table 25 Number of Students in Business Units ............................................................... 92

Table 26 Number of Business Graduates by Level ............................................................ 93

Table 27 Number of Responding Units Offering Degrees by Subject and Level .................... 94

Table 28 General Business Degree Specialization Areas ................................................. 95

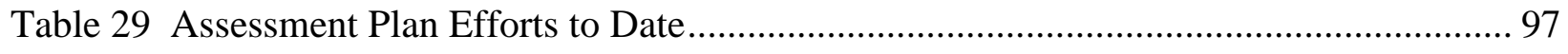

Table 30 Accreditation Plan Efforts by Accreditation Agency ........................................... 98

Table 31 Motivation for Assessment Plan Creation ...................................................... 101

Table 32 Aids Used to Facilitate Assessment Plan Development ...................................... 102

Table 33 Year Units Began Assessment Plan.................................................................. 103

Table 34 Reported Years of Assessment Plan Updates ................................................... 103

Table 35 Frequency of Computer Resource Usage in Assessment Monitoring ...................... 104

Table 36 Location of Assessment Discussions ............................................................. 105

Table 37 Method of Distribution of Assessment Results ................................................ 106

Table 38 Perceived Impact Accreditation has on Assessment Efforts ................................. 107

Table 39 Means of Questions Grouped by Principle ....................................................... 108

Table 40 Principle 1 - Institution and Unit Mission Reflection in Outcomes and Assessments 109

Table 41 Principle 2 - Use of Direct Assessment Methods............................................. 111

Table 42 Principle 2 - Use of Indirect Assessment Methods ........................................... 112

Table 43 Principle 2 - Indication that Learning is Multidimensional, Integrated, and Revealed in

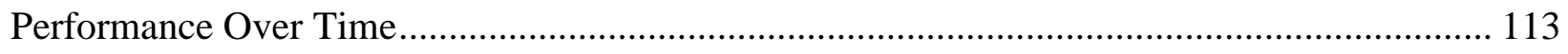

Table 44 Principle 3 - Extent Programs Have Clear, Explicitly Stated Purposes ................... 115 
Table 45 Principle 4 - Level of Attention Given to the Student Experiences that Lead to

Outcomes 117

Table 46 Principle 5 - Assessment as an Ongoing Process ............................................... 119

Table 47 Principle 6 - Assessment Collaboration Across Campus Community...................... 121

Table 48 Principle 7 - Assessment Impact on Items of Importance.................................... 123

Table 49 Principle 8 - Assessment as a Change Agent .................................................. 125

Table 50 Principle 9 - Assessment Accountability and Distribution of Assessment Information

Table 51 Frequency and Means of Success Factor Responses .......................................... 129

Table 52 Correlations of Success Factors and Assessment Principles ................................. 132

Table 53 Tukey’s HSD Test Homogeneous Subsets by Significantly Different Principle ....... 135

Table 54 Means of Principle 1 by Accreditation Agency .................................................. 136

Table 55 Principle 1 Mission Clarity in Assessments and Outcomes Univariate Test Results . 137

Table 56 Tukey's HSD Test of Multiple Comparisons Principle 1 ...................................... 138

Table 57 Means of Direct Assessments by Accreditation Agency..................................... 140

Table 58 Principle 2 Direct Assessment Univariate Test Results....................................... 143

Table 59 Tukey's HSD Test of Multiple Comparisons Principle 2a Direct Assessments........ 144

Table 60 Means of Indirect Assessments by Accreditation Agency .................................... 149

Table 61 Principle 2 Indirect Assessment Univariate Test Results .................................. 151

Table 62 Tukey's HSD Test of Multiple Comparisons Principle 2b ................................... 152

Table 63 Means of Principle 3 by Accreditation Agency ............................................... 157

Table 64 Principle 3 Univariate Test Results ............................................................... 158

Table 65 Means of Principle 4 by Accreditation Agency ................................................ 159 
Table 66 Means of Principle 5 by Accreditation Agency ...................................................... 160

Table 67 Principle 5 Univariate Test Results ...................................................................... 161

Table 68 Tukey's HSD Test of Multiple Comparisons Principle 5 .......................................... 162

Table 69 Means of Principle 6 by Accreditation Agency ........................................................... 164

Table 70 Principle 6 Univariate Test Results ....................................................................... 165

Table 71 Tukey's HSD Test of Multiple Comparisons Principle 6 ........................................... 166

Table 72 Means of Principle 7 by Accreditation Agency ......................................................... 168

Table 73 Means of Principle 8 by Accreditation Agency ....................................................... 169

Table 74 Principle 8 Univariate Test Results .................................................................. 170

Table 75 Tukey's HSD Test of Multiple Comparisons Principle 8 ………………………........ 171

Table 76 Means of Principle 9 by Accreditation Agency ...................................................... 174

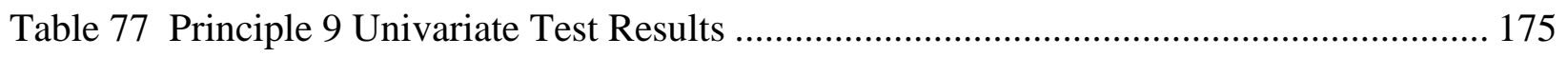

Table 78 Means of Assessment Commitment by Accreditation Agency .................................. 176

Table 79 Assessment Univariate Test Results ..................................................................... 177

Table 80 Tukey’s HSD Test of Multiple Comparisons Assessment ......................................... 178

Table 81 Means of Accreditation Commitment by Accreditation Agency ............................... 182

Table 82 Accreditation Commitment Univariate Test Results .............................................. 183

Table 83 Tukey's HSD Test of Multiple Comparisons Accreditation ..................................... 184

Table 84 Means of Revision Influences by Accreditation Agency .......................................... 187

Table 85 Revision Influence Univariate Test Results....................................................... 188

Table 86 Tukey's HSD Test of Multiple Comparisons Revision ................................................ 189

Table 87 Means of Success Factors by Accreditation Agency …………................................. 191

Table 88 Success Factors Univariate Test Results ………...................................................... 193 
Table 89 Tukey’s HSD Test of Multiple Comparisons Success........................................... 194 


\section{CHAPTER 1: INTRODUCTION}

\section{Problem Statement}

Business education in the United States is facing challenging demands, including the new pressures of globalization, economic uncertainties, ever-evolving technologies, and a changing student profile. Increasing globalization has led to global competition for students and faculty, the acknowledgment of differences in organizational and cultural values, and the emergence of new competitors. Rapid changes in the economy is reflected in the shifts in funding sources, including endowment inflation and state funding decreases, and has affected cost structure differences in delivery systems. Technological advances have changed how business organizations function, specifically with the exploding opportunities in e-business, which impose an increased need for speed and the ability to conduct business activity anytime, anywhere. Furthermore, business education is facing an increasing percentage of nontraditional students with specialized needs and a shortage of doctoral business graduates and faculty (AACSB, 2005; AACSB, 2002; Fields, 2006). In addition, some critics believe business schools in the United States are failing to provide an adequate education to students (Hubbard, 2006).

In 2003-2004, there were nearly 1.4 million bachelor's degrees awarded. Twenty-two percent $(307,100)$ of those degrees were awarded to business students. More degrees were awarded in business than in any other field of study. In fact, the field of business had over twice the number of majors than the next largest field, social sciences and History (U.S. Department of Education [USDE], 2006a). Given the large number of students in the business field, understanding the state of affairs in this area and identifying potential areas of improvements could have a significant impact on methods of improving not just business education, but higher education as a whole. 
Business schools must prepare students for employment beyond the traditional management skill set. After researching the state of business education, an AACSB Task Force (2002), found that:

Management education is shaped by many variables, including the needs and preferences of consumers of business education; the knowledge, abilities, and skills employers expect graduates to possess; the choice of providers available to those interested in pursuing management degrees; and the resources business schools need to serve their customers. These are among the variables that make up the context for management education, which is very different today than it was even as recently as the mid-1990s. (p. 6) Creating a visible statement of quality assurance, such as accreditation, allows prospective students and employers to see that the academic quality of the business program has met standards for excellence. In addition, accreditation assists programs in meeting the challenges that face business education (AACSB, 2005).

The definition of quality has been a topic of discussion since the time of Socrates and Plato (Sower \& Fair, 2005). Wergin (2003), in defining quality academic departments, claimed that the academic definition of quality has been what Garvin referred to as the transcendent view of quality. This interpretation implies that faculty recognize quality when they see it but cannot explain or define quality. Garvin (1984) asserted that quality is an "innate excellence” (p. 25). Consumers know that they want high quality goods. In this regard, an education is no different. Students will shop around and try to get what they feel is the best education or competitive edge. Institutions can no longer be complacent. They must respond to calls for improvement in “dramatic ways" (USDE, 2006b, p. ix.). Students are also considering leaving the United States 
for their business degrees, which widens the scope of competition to global capacities and intensifies competition among business academic units (AACSB, 2002).

The Secretary of Education's Commission on the Future of Higher Education stated in $A$ Test of Leadership: Charting the Future of U. S. Higher Education:

In this consumer-driven environment, students increasingly care little about the distinctions that sometimes preoccupy the academic establishment, from whether a college has for-profit or nonprofit status to whether its classes are offered online or in brick-and-mortar buildings. Instead, they care - as we do - about results. (USDE, 2006b, p. vii,)

One of the goals set forth by this Commission for higher education is to provide "highquality instruction" and to make education more affordable (USDE, 2006b, p. vii). The U. S. Secretary of Education created the Commission in 2005 and charged the Commission to examine four key areas: access, affordability, quality, and accountability. The Commission found that problem areas were compounded by the lack of information about quality and cost and a significant lack of accountability mechanisms. Although the Commission indicated that there has been increased attention to student learning by academic institutions and accreditation agencies, they feel more should be done in this area. The Commission recommended that "Postsecondary education institutions should measure and report meaningful students learning outcomes” (p. 23). The Commission found that "at a time when we need to be increasing the quality of learning outcomes and the economic value of a college education, there are disturbing signs that suggest we are moving in the opposite direction" (p. 12). The Commission also recommended that accreditation agencies make performance outcomes the core of their assessment (USDE, 2006b). 
The accountability movement in the1990s, following the assessment movement in the1980s, produced the link between accreditation and student outcomes assessment (Lubinescu, Ratcliff, \& Gaffney, 2001). The chronological appearance of the interest in assessment before accreditation meant that some accreditation bodies were examining assessment and working with their decision-making bodies to integrate outcomes assessment into their standards for accreditation as early as the 1980s (Davenport, 2001; Rice, 2006).

Assessment and accreditation share many overlapping goals and characteristics. A common criterion is that both examine the quality of education. Accreditation indicates that the institution or unit has met a high quality of standards set by the accrediting agency (Alstete, 2004; Baker, 2004; Council for Higher Education Accreditation [CHEA], 1996; Lubinescu, Ratcliff, \& Gaffney, 2001) and assessment seeks to improve the excellence of programs and institutions (Astin, 1991; Banta \& Associates, 2002; Huba \& Freed, 2000; Jones \& DiRichard, 2005; Palomba \& Banta, 2001). Today, both the accreditation and assessment movements are strong (Lubinescu, Ratcliff, \& Gaffney, 2001; Alstete, 2004). As Baker (2004) noted, "Assessment is not a fad, and it will not go away" (p. 31). In fact, as institutions strive to fulfill the recommendations of the U. S. Department of Education Commission, the link will grow stronger.

Although individually assessment and accreditation have been discussed extensively, there is little research and understanding of the connection between accreditation and assessment (Lubinescu, Ratcliff, \& Gaffney, 2001). Lubinescu et al. posited that the relationship between the two today focus on two questions:

1. How should student learning outcomes be demonstrated in the accreditation process? 
2. How should assessment information be used to show improvement in programs, services, and student learning?

Little assessment and accreditation research has delved into the disciplinary areas of higher education; however, disciplinary accreditors often provide a "strong and positive influence on assessment of student achievement in the major" (Palomba, 2002, p. 213).

Accreditation emerged as a national phenomenon in 1906 (Alstete, 2004) and assessment of collegiate learning as a particular application of educational and developmental psychology arose as early as the 1930s (Ewell, 2002); the two were not considered to be linked until over half a century later (Lubinescu, Ratcliff, \& Gaffney, 2001). Since its introduction, accreditation can be viewed as having three generations of growth and change. The current generation, which began in the late 1970s, is characterized by diverse quality standards among agencies, focused self-studies, coordinated evaluations, and other periodic reviews (Alstete, 2004). Assessment is "the systematic collection, review, and use of information about educational programs undertaken for the purpose of improving student learning and development" (Palomba \& Banta, 1999, p. 4). The current assessment and accreditation movements and the integration of the two activities can be traced back to the last 27 years.

The integration of assessment and accreditation has roots in a report by the Commission on Recognition of Post-Secondary Accreditation (CORPA) in 1979, about which Casey and Harris (1979) called for "accreditation teams to begin to look for evidence of student achievement used for the award of credit and degrees, and make judgments about the quality of the institution in light of the adjudged student achievement compared with degrees awarded" (cited in Alstete, 2004, p. 13). This connection was solidified further when, in 1988, secretary of education William Bennett, issued an executive order that required accrediting agencies to verify 
and assess student achievement (Wright, 2002). In the early 1990s, assessment began to focus on improving learning and teaching in higher education (Huba \& Freed, 2000). According to Ewell (1993), as accrediting bodies grow in influence and replace states as the primary external stimulus for institutional interest in assessment, the establishment of effective assessment programs becomes more crucial to the sustainability of a program or institution. Accreditation is recognized as a symbol that an organization has met high standards and assures quality and excellence in education. Assessment and accreditation are both premised on the importance of quality assurance in education and both strive to contribute to and enhance the educational enterprise (Lubinescu, Ratcliff, \& Gaffney, 2001). The Middle States Commission on Higher Education (2005) stated: "The fundamental question asked in the accreditation process is, 'Is the intuition fulfilling its mission and achieving its goals?' This is precisely the question that assessment is designed to answer, making assessment essential to the accreditation process" ( $\mathrm{p}$. 4).

For business administration programs, there are three organizations that can grant accreditation. These organizations are: The Association to Advance Collegiate Schools of Business (AACSB International); The Association of Collegiate Business Schools and Programs (ACBSP); and The International Assembly for Collegiate Business Education (IACBE).

AACSB was organized in 1916 and has been devoted to the promotion and improvement of business administration and management programs in colleges and universities since that time. The standards that AACSB currently uses to evaluate business schools were adopted in April 2003 and revised in January 2004 (AACSB, 2004). The Association of Collegiate Business Schools and Programs (ACBSP) was founded in 1988 with a teaching emphasis reflected in its accreditation standards. The current ACBSP standards were revised in June 2004 (ACBSP, 
2004a). The International Assembly for Collegiate Business Education (IACBE) was created as a response to a dislike of the prescriptive standards imposed by other agencies (IACBE, 2004). The IACBE uses outcomes assessment as its only measurement and requirement for accreditation (IACBE, 2004). Standards are the agreed upon levels of achievement that programs must meet to gain recognition by accrediting agencies; they are consensus documents (Davenport, 2001). Although the purpose of the standards is to set goals of excellence and to provide an opportunity and encouragement for programs to advance toward those goals, little evidence has been gathered about the relationship between accreditation standards and educational excellence in professional programs (Hagerty \& Stark, 1989).

AACSB, ACBSP, and IACBE, and all major accrediting bodies (Banta, 2005), require assessment. Very little research has examined assessment in business schools and the extent to which business programs utilize best practices in assessment. Given the requirement of assessment, it would seem logical that accredited business schools would engage in more assessment than those which are not accredited. In fact, this may not be the case. One study of Economics programs in 1990, found that business programs that were accredited by AACSB were less likely to have a stated assessment plan when compared to those without the AACSB recognition. Although not based on the research findings, a conclusion drawn from the study to explain this phenomenon was that the possibility that AACSB schools are more researchoriented and may tend to ignore assessment. The research did show that $62 \%$ of those surveyed were planning to increase their use of assessment efforts, although slightly more effort was predicted in non- accredited schools than in those with AACSB accreditation (McCoy, Chamberlain, \& Seay, 1994). 
This study sought to uncover information that might address the challenges faced by business schools in the United States. Business schools are seeking methods of improving the services and education that they offer to students, as well as their position in the academic market. This research focused on assessment and accreditation; both methods of indicating the quality of institutions and programs. Because of the lack of concise literature about assessment and accreditation in business schools, and especially the lack of any research that encompasses all three accrediting bodies for schools of business, the results of this study have the potential to provide great benefit to schools that are seeking to improve their programs or those that wish to know the levels of assessment activity in business schools across the nation. In addition, this study adds to the literature of education by providing the state of assessment in business schools. 


\section{Purpose}

The purpose of this study was to determine to what degree accredited business schools follow the best practices in assessment and identify the relationship of assessment to the success of a business school. Success, as it relates to educational achievement by departments, is defined in Chapter 3, but includes criteria related to students and graduates (i.e. graduation rates, internship or employer feedback, etc.). In addition, the study explored the potential differences in assessment standards and practices among the three accrediting bodies.

Through this inquiry, a clearer understanding of assessment in accredited business schools was acquired. The results of this research may be used by institutions and accrediting bodies to develop more effective assessment standards for accreditation and practical application. In addition, this study adds to the education literature on assessment and provides insight into discipline-specific practices in business education.

The following research questions were explored in this study:

1. To what degree do accredited business schools follow the best practices in assessment?

2. To what degree does assessment activity impact the success of business schools?

3. Is there a significant difference in outcomes assessment practices utilized by business schools according to their accrediting body (by IACBE, ACBSP, and AACSB)? 


\section{Summary}

This chapter has outlined the background of the problem, the significance of the study, and the research questions. Chapter 2 presents the review of literature related to assessment practices and principles, as well as the three accreditation bodies for business schools and their standards for assessment. Chapter 3 describes the research design that was used to explore the research questions including the research methods, which contain a description of the participants, data collection procedures, and analysis. The results of the research are presented in Chapter 4 and discussed and Chapter 5 discusses the results of the research and the conclusions that are drawn from the results. The Appendices contain the cover letter and the instrument completed by participating business schools. 


\section{CHAPTER 2: REVIEW OF RELEVANT LITERATURE}

\section{Introduction}

This chapter will review the literature relevant to the study. Assessment and accreditation will be explained in detail. A review of accreditation in business schools will show the level of accreditation awarded in the United States and the characteristics of accreditation. Then assessment will be examined, including the use of student learning outcomes. The assessment analysis in the literature review focuses on the best practices of assessment and their application in business schools. To accomplish this goal, research is based on a framework developed in 1996, under the auspices of the Association of American Higher Education (AAHE) Assessment Forum, with support from the Fund for the Improvement of Postsecondary Education and the Exxon Education Foundation. The AAHE (1992) Assessment Forum developed nine principles of good practice for assessment. These principles are the foundation on which many successful assessment plans are based. According to AAHE (1992), the nine principles are:

1. The assessment of student learning begins with educational values.

2. Assessment is most effective when it reflects an understanding of learning as multidimensional, integrated, and revealed in performance over time.

3. Assessment works best when the programs it seeks to improve have clear, explicitly stated purposes.

4. Assessment requires attention to outcomes but also and equally to the experiences that lead to those outcomes.

5. Assessment works best when it is ongoing not episodic.

6. Assessment fosters wider improvement when representatives from across the educational community are involved. 
7. Assessment makes a difference when it begins with issues of use and illustrates questions that people really care about.

8. Assessment is most likely to lead to improvement when it is part of a larger set of conditions that promote change.

9. Through assessment, educators meet responsibilities to students and to the public.

Each principle will be discussed further and substantiated by numerous assessment scholars.

Purposes of Assessment and Learning Outcomes

Jones and RiCharde (2005) noted that the "primary purpose of most assessment plans is the improvement of educational programs and student learning" (p. 4). In addition, Lambert and Lines (2000) described four purposes of assessment. The first, a formative role, is to provide feedback to teachers and students about progress and to support future learning. The second is a summative role, to provide information about the level of student achievement at points during and at the end of the education cycle, and is used often for the purpose of determining grades. The third is the certification role that provides a means for selecting or certifying by qualification. This serves as a potential checkmark that the individual or program achieved the desired outcome. Finally, the evaluation role focuses on making judgments concerning the effectiveness or quality of individuals and institutions in the system as a whole. Palomba and Banta (1999) indicated that assessment plans should measure what students know, can do, and value. The question, then, is, after we state what these students should know, do, and value, as well as define the learning outcomes, then how do we determine if these students have achieved the outcomes? 
Learning outcomes can be categorized by three domains developed by a group of education psychologists headed by Benjamin Bloom (1956). Bloom and his colleagues determined that there were three domains of student learning. These domains are:

Affective: Feelings, preferences, values.

Cognitive: Thinking, getting, evaluating, and synthesizing information.

Psychomotor: Physical and perceptual activities and skills.

Cognitive objectives can be organized using a taxonomy developed by Bloom. This taxonomy helps define development levels, including knowledge, comprehension, application, analysis, synthesis, and evaluation (see Table 1). 
Table 1

Bloom's Taxonomy of Cognitive Objectives

\begin{tabular}{|c|c|c|}
\hline Level & Definition & Action Words \\
\hline Knowledge & $\begin{array}{c}\text { Recognize or recall data or } \\
\text { information. }\end{array}$ & $\begin{array}{l}\text { arrange, define, duplicate, label, list, } \\
\text { memorize, name, order, recognize, } \\
\text { relate, recall, repeat, reproduce state }\end{array}$ \\
\hline Comprehension & $\begin{array}{l}\text { Understand the meaning, translation, } \\
\text { interpolation, and interpretation of } \\
\text { instructions and problems. State a } \\
\text { problem in one's own words. }\end{array}$ & $\begin{array}{l}\text { classify, describe, discuss, explain, } \\
\text { express, identify, indicate, locate, } \\
\text { recognize, report, restate, review, } \\
\text { select, translate }\end{array}$ \\
\hline Application & $\begin{array}{l}\text { Use a concept in a new situation or } \\
\text { unprompted use of an abstraction. } \\
\text { Applies what was learned in the } \\
\text { classroom into novel situations in } \\
\text { the work place. }\end{array}$ & $\begin{array}{l}\text { apply, choose, demonstrate, dramatize, } \\
\text { employ, illustrate, interpret, operate, } \\
\text { practice, schedule, sketch, solve, use, } \\
\text { write }\end{array}$ \\
\hline Analysis & $\begin{array}{l}\text { Separates material or concepts into } \\
\text { component parts so that its } \\
\text { organizational structure may be } \\
\text { understood. Distinguishes between } \\
\text { facts and inferences. }\end{array}$ & $\begin{array}{c}\text { analyze, appraise, calculate, } \\
\text { categorize, compare, contrast, } \\
\text { criticize, differentiate, discriminate, } \\
\text { distinguish, examine, experiment, } \\
\text { question, test }\end{array}$ \\
\hline Synthesis & $\begin{array}{l}\text { Builds a structure or pattern from } \\
\text { diverse elements. Put parts together } \\
\text { to form a whole, with emphasis on } \\
\text { creating a new meaning or structure. }\end{array}$ & $\begin{array}{l}\text { arrange, assemble, collect, compose, } \\
\text { construct, create, design, develop, } \\
\text { formulate, manage, organize, plan, } \\
\text { prepare, propose, set up, write }\end{array}$ \\
\hline Evaluation & $\begin{array}{l}\text { Make judgments about the value of } \\
\text { ideas or materials. }\end{array}$ & $\begin{array}{l}\text { appraise, argue, assess, attach, choose } \\
\text { compare, defend estimate, judge, } \\
\text { predict, rate, core, select, support, } \\
\text { value, evaluate }\end{array}$ \\
\hline
\end{tabular}


There are numerous methods to assess cognitive skills. Students in the lower levels of Bloom's taxonomy may complete multiple-choice exams to show their knowledge of principles within the business discipline. As students progress through the learning taxonomy, the assessment measure must change to reflect the level of learning. For example, students could not show on a multiple choice exam their ability to analyze a business problem; however, using a case study, students could write a reflective paper showing their skills in analyzing the business problem and their insights and understanding of the concepts of business.

Affective outcomes such as managing emotions, establishing identity, clarifying purpose, and developing integrity can be assessed through survey instruments. Survey instruments can provide insight into the development of personal and social aspects of students, whereas they may provide little to no insight into the students' mastery of skill sets (Palomba \& Banta, 1999). To assess psychomotor skills, a student may be observed performing a simulation or a selected skill (Jones, 2002). Most programs will have outcomes and assessments in each of the developmental categories just described (Palomba and Banta, 1999). Further discussion of assessment concepts and business school use of assessment practices is provided in the discussion of best practices in assessment.

\section{Accreditation}

As indicated in Chapter 1, there are three specialized accreditation agencies for schools of business in higher education. The first, and largest, is the Association to Advance Collegiate Schools of Business (AACSB). The AACSB is committed to the promotion and improvement of higher education in business administration and management (AACSB, 2004). The second agency, the Association of Collegiate Business Schools and Programs (ACBSP) has a teaching emphasis reflected in its June 2004 accreditation standards (ACBSP, 2004b). The newest agency 
is the International Assembly for Collegiate Business Education (IACBE). IACBE (2004) accreditation is based solely on outcomes assessment. Current standards of each agency have components for assessment of outcomes (AACSB, 2005; ACBSP, 2004b; IACBE, 2004). Earlier accreditation standards focused on inputs, rather than the outcomes. The accreditation status based on earlier standards was centered on questions concerning what was taught, rather than the effectiveness of the teaching; the number of doctoral-qualified faculty, rather than the quality of the teaching; and the amount of funds spent on facilities, rather than the impact the expenditures had on the quality of students' educational experiences (Henninger, 1994). The shift to student learning began with AACSB in the early 1970s. At that time, AACSB began a serious review of its standards and recognized the importance of outcomes assessment (Henninger, 1994).

The total number of schools with specialized accreditation for bachelor's programs is 785 (AACSB, 2006; ACBSP, 2006; IACBE, 2006). The largest specialized accreditation group is the AACSB with 477 schools that have received accreditation at the undergraduate level as of March 2006. Of these schools, only 42 have accreditation limited to the undergraduate degree alone. Over half of the AACSB schools (53\%) have accredited both the undergraduate and master's programs, whereas another $29.5 \%$ have accreditation at all three levels (undergraduate, master's and doctoral). Master's-only and master's-and-doctorate accredited institutions represent less than 5\% each of all AACSB accredited schools (AACSB, 2006).

The ACBSP accredits associate degree programs as well as bachelor's- and master'slevel programs. ACBSP is the only association that accredits associate-level programs. There are 18 schools that have both baccalaureate and associate accreditation; 140 of which have their four-year programs accredited, and 136 two-year only institutions (ACBSP, 2006). 
The IACBE has 150 accredited members and accredits schools offering bachelor's and master's degrees. The IACBE accreditation typically includes all program levels at an institution (IACBE, 2006). The business-oriented accreditation bodies have many similarities and many differences. Perhaps the most significant factor that the agencies have in common is that they each believe that assessment plans should vary significantly from campus to campus because assessment plans should be based on the program goals and the institutional mission (AACSB, 2005; ACBSP, 2004b; IACBE, 2004). Throughout the discussion of best practices in assessment, relevant highlights will be discussed to show each agency's view on the principle and its importance to business academic units.

\section{Assessment and Accreditation Connection}

As noted by Jones and RiCharde (2005), assessment results can be used for, and may be required by, accreditation agencies and state governments. The Council for Higher Education Accreditation (CHEA), whose responsibilities all relate to advancing the usefulness of accreditation in American higher education, has asserted that accreditation is built on assessment (CHEA, 1996). CHEA is not an accreditation agency; however, it recognizes accreditation agencies that successfully complete a review process. There are approximately 80 accrediting organizations in the United States (Eaton, 2006). These organizations are recognized by either CHEA or the United States Department of Education (USDE), or both (CHEA, 2006a). Recognition of accreditors in the United States requires scrutiny of the quality and effectiveness of accrediting organizations. CHEA seeks to assure that accrediting organizations contribute to maintaining and improving academic quality and is funded by institutional dues. The USDE seeks to assure that accrediting organizations contribute to maintaining the soundness of 
institutions and programs that receive federal funds. USDE recognition is funded by the U.S. Congress (Eaton, 2006).

CHEA (1996) has described accreditation as having the following characteristics:

- Accreditation involves judgments of quality and effectiveness of an institution/program against a set of expectations (standards, criteria).

- Accreditation is a form of non-governmental self-regulation as contrasted to compliance to state and/or federal rules, regulations, and codes.

- Accreditation is grounded in the institution's or program's mission, history, and sense of purpose.

- Accreditation acknowledges and respects the autonomy and diversity of institutions and programs.

- Accreditation provides assurance to the public that accredited institutions and programs meet or exceed established public expectations (standards) of quality.

- Accreditation is the responsibility of an external commission.

- Faculty involvement is essential to valid accreditation.

- Accreditation is conducted on a cyclic basis, usually 5-10 years. Shorter cycles are used when serious problems are noted.

- Accreditation recently has emphasized student learning and development as an important criterion of effectiveness and quality.

As has been stated in the May 2002 CHEA Chronicle, the "legitimacy of accreditation as a protector of academic quality in higher education is increasingly challenged in the absence of quality review that pays significant attention to outcomes" (CHEA, 2002). Currently, CHEA recognizes AACSB and ACBSP (CHEA, 2006b). IACBE is currently attempting to achieve 
CHEA recognition (CHEA, 2006c). They have been reviewed three times and are still working to correct issues and meet CHEA recognition standards, issues exist in the areas of public disclosure of student achievement data, public disclosure of accreditation status, processes for accreditation (single process for US and International institutions), and clarification of assessment's role in the accrediting standards (CHEA, 2009).

The current AACSB standards have a large section (22 pages out of the total 77 pages) dedicated to "Assurance of Learning" standards. This section gives schools guidance on how to create learning objectives and how to assess those goals (AACSB, 2005). The ACBSP standards provide an integrated approach to outcomes assessment. Because the ACBSP focus is on teaching, the standards focus on student learning. Each standard has some components of assessment, and one standard, "Measurement and Analysis of Student Learning and Performance" is dedicated to the outcomes assessment plan: "ACBSP believes that the learning outcomes of the education process are of paramount importance" (ACBSP, 2004, p. 19 ). Of the three accreditation associations for business, IACBE has the strongest focus on outcomes assessment. In fact, its Accreditation Process Manual boasted that it is "distinctly different" (IACBE. 2005, p. 1) because it defines business education excellence on the results of assessment of educational outcomes. In fact, it does not use the word "standards" to define its requirements; it focused on "expectations" (p. 1). Its primary focus for evaluating business schools is the outcomes assessment practices at that institution.

\section{Assessment Principles of Best Practice}

In this section, the assessment principles advocated by assessment scholars will be addressed. Figure 2.1 is the conceptual frameworkk that guides this study. 


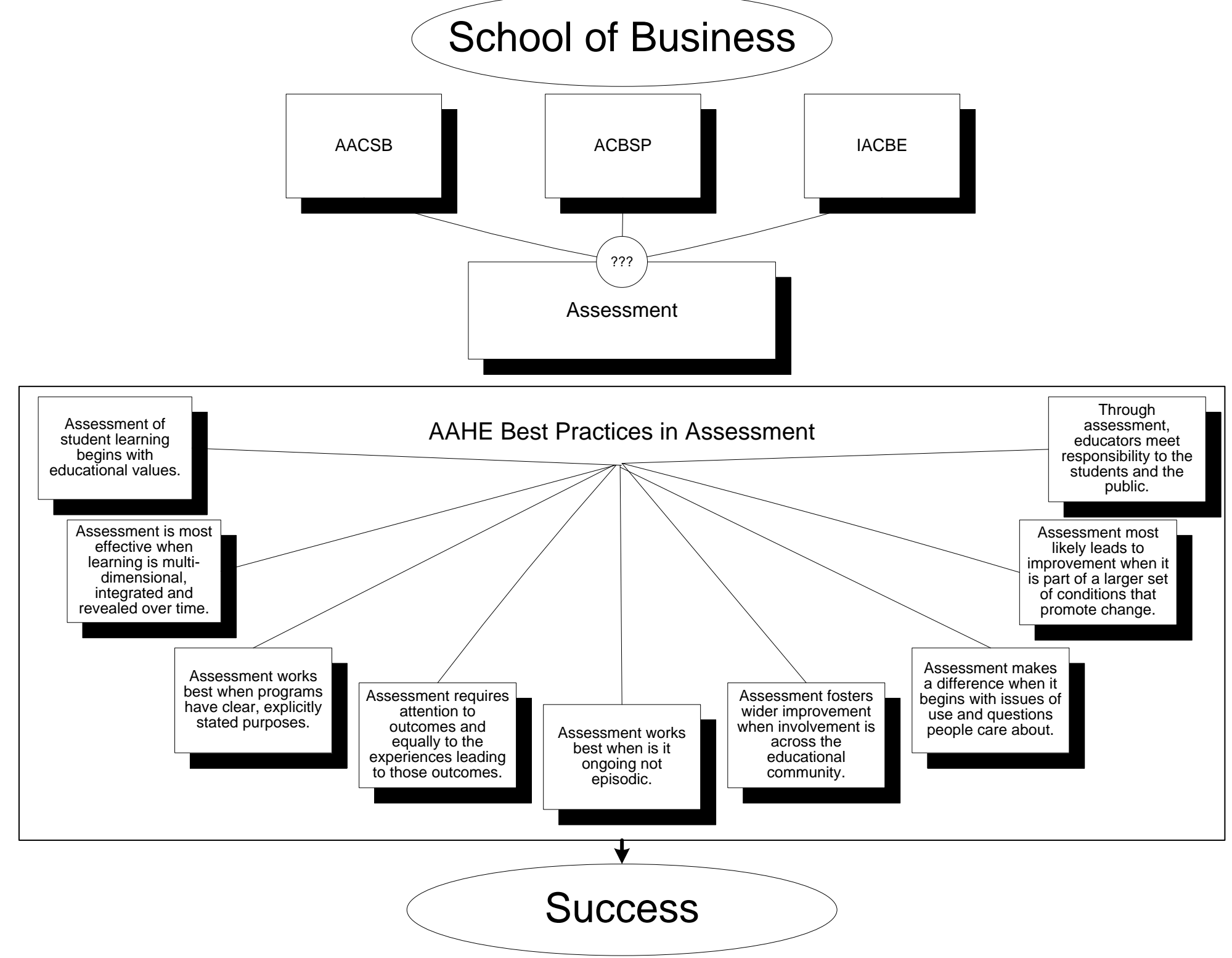

Figure 1. Concept Map 


\section{Principle 1}

The assessment of student learning begins with educational values. This first assessment practice requires institutions to consider and declare a vision of intended learning for students. This vision contains the essential features of the academic values of the institution. Should the development of these learning values be overlooked, the assessment effort will not be able to aid in the effort of improving the student learning. In its simplest form, this principle requires the assessment program to have stated values linked to the mission and vision of the institution. The assessment effort should not be the focus; assessment is the vehicle to improve the institution. This is an extremely important principle that considers the complete education of the student. The mission statement should be developed and updated periodically with input from all stakeholders and should state those items that the institution values. The mission and purpose serve as an institutional directive and provide a starting point for assessment (Banta, Lund, Black, \& Oblander, 1996). Palomba and Banta (1999) noted that to make assessment effective, "educators must be purposeful about the information they collect" (p. 4). Pike (2002) also notes that "What institutional experience tells us is that having goals for student learning is an essential part of effective assessment" (p. 133). This principle is also a fundamental component of accreditation.

In the October 5, 2005 edition of her bi-weekly publication, CHEA President Judith Eaton stated that "All accreditation starts with a mission. A mission-based approach means that expectations of the quality and performance of individual institutions are grounded in the purposes that each college and university had been created to serve" (Eaton, 2005). She further elaborated that although individual institutions should maintain autonomy, they retain a 
responsibility to provide academic opportunities and leadership mindful of the institution mission and constituents (Eaton, 2005).

All three accreditation agencies stress in their standards that stated learning outcomes should reflect the mission and values of the individual business unit, and that assessment efforts should seek a greater understanding of those objectives. These agencies also indicate that the student learning will be, and is expected to be, different at each institution because of the differences in the mission and vision (AACSB, 2005, ACBSP, 2004b, IACBE, 2005).

\section{Principle 2}

Assessment is most effective when it reflects an understanding of learning as multidimensional, integrated, and revealed in performance over time. The assessment plan must contain multiple methods of assessment including both direct and indirect measures. Direct assessment measures determine student learning and require students to apply their knowledge and skills as they complete an activity or instrument (Palomba \& Banta, 1999). Examples of direct assessment include "performances, creations, results of research or exploration, interactions within group problem solving, or responses to questions or prompts" (Maki, 2004, p. 88). Indirect assessments, like focus groups, interviews and surveys, ask students to reflect on their learning rather than to demonstrate their abilities (Palomba \& Banta, 1999).

The use of multiple measures is required to ensure the success of the assessment plan and gain an accurate understanding of the student learning taking place (Maki, 2002 \& 2004; Hernon \& Dugan, 2004; Banta, Lund, Black, \& Oblander, 1996). These efforts, although perhaps sometimes seemingly redundant, provide triangulation, which means that there are multiple instances that support a claim, and therefore provide a "richer portrayal of student learning" (Hernon, 2004, p. 150). 
Maki (2004) stated that assessment efforts may be quantitative or qualitative. Quantitative measures indicate an interpretative value of a numerical score, for example, the scoring of a multiple choice exam like the ETS Major Field Test in Business. Alternatively, qualitative efforts allow observations. Students and faculty can elaborate on the students' level of learning and interpret skills in a method that is more personal and, often, allows more insight to the level of learning. Using both qualitative and quantitative measures adds a "depth and breadth to interpretations of student learning" (Maki, 2004 p. 87). To determine which measurement to use, the outcome should be reviewed to determine which method lends itself to providing the needed data to examine the learning. Outcomes at lower levels of Bloom's cognitive taxonomy are often easier to quantify than those that require a higher level of cognitive ability. Showing the ability to know or perhaps define, at the lowest level, would be easier to quantify than the analysis of a case or the creation of a business plan, which would be considered a performance objective (Palomba \& Banta, 1999).

The use of the assessment data have value as it is discussed and used to refine a learning experience and does not have to be numerical. In fact, when these methods are combined, a more complete picture of the actual learning is made. For example, North Missouri State University uses a standardized test to assess student performance in business, but it also combined those results with other culminating experiences in the major, such as senior seminar courses or a thesis requirement and exit surveys (Mirchandani, Lynch, \& Hamilton, 2001). These multiple measures provide triangulation, and therefore provide a more comprehensive indication of student learning. 
Institutions may want to look at the commercially available assessment instruments as well as develop specific local instruments. The Educational Testing Service (ETS) offers a Major Field Test (MFT) in Business. ETS (2006) gave the following reasons for using its instrument:

- Meeting External Requirements: MFTs provide reliable documentation of performance for accreditation, strategic planning and performance-based funding.

- Benchmarking and Trend Analysis: Facilitates comparison of scores to measure student achievement, document program effectiveness and demonstrate program improvement over time.

- Developing and Improving Curricula: A variety of score reports allow for detailed curriculum review and evaluation.

- Assessing Student Achievement: Faculty and administrators can assess student level of achievement within a field of study compared to that of other students in their program and to the national comparative data.

Using one measure to examine student learning, even a comprehensive examination like the Major Field Test in Business, would not provide a complete understanding of learning. The results of a study called Educational Testing Service's Major Field Test in Business:

Implications for Assessment reinforced the need for multiple measures at every level of assessment and especially for program-level assessments (Mirchandani, Lynch, \& Hamilton, 2001). As Table 2 demonstrates, there are multiple assessment measures for each level of assessment. The assessment results are not just beneficial to the level that they are created for or intended to provide learning evidence. Results can provide additional, "meaningful" (Jones, 2002, p. 90), information to other levels. For example, King's College's Accounting program 
uses course-embedded assessments to determine the learning at the course level, as well as for its professional preparation program (Jones, 2002).

Indirect and direct measures can be used to measure course-level learning outcomes as well as program-level outcomes. In addition, these measures can provide useful information about the achievement of institutional level outcomes (see Table 2). AACSB (2005), ACBSP (2004b), and IACBE (2005) all recommended using multiple assessment measures to form an understanding of student learning. In fact, each agency has given examples of direct and indirect methods of assessment in their standards; for instance, all three agencies mention using projects and exams to assess student learning. 
Table 2

Middle States Direct and Indirect Assessment Examples

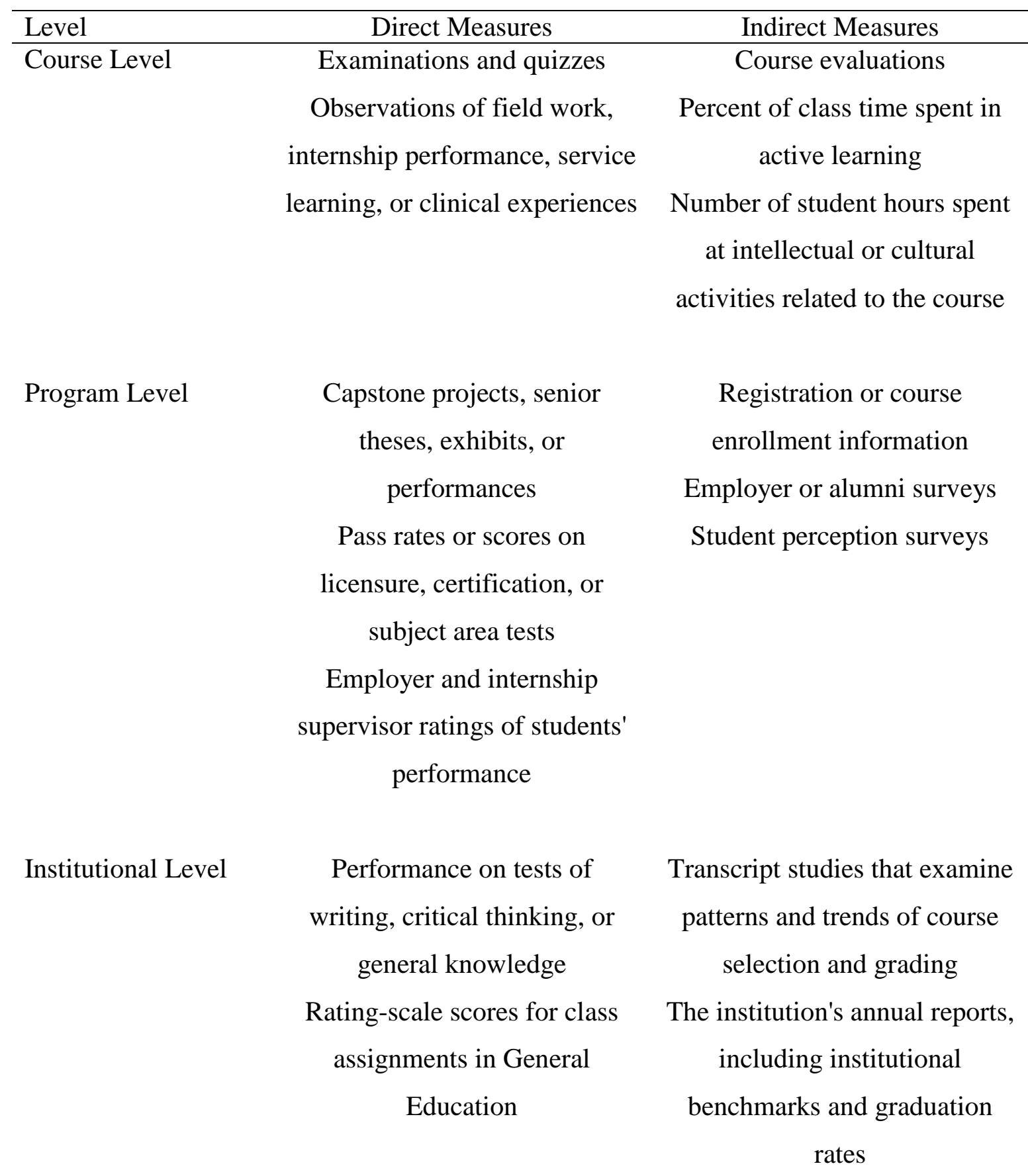

Note. From Middle States Commission on Higher Education (2004). 


\section{Principle 3}

Assessment works best when the programs it seeks to improve have clear, explicitly stated purposes. The assessment plan must have goals and those goals must be in line with the goals of the course, program, and university. The use of assessment should provide a collective means to discover the fit between institutional or programmatic expectations for student achievement and patterns of actual student achievement (Maki, 2002). For over 50 years, AACSB-accredited schools have struggled with core classes and stated purposes. These classes represent commonbody-of-knowledge (CBK) requirements for undergraduate business programs (Eldredge \& Galloway, 1983). The components of the core were detailed in AACSB standards. Although these standards did not prescribe all the courses, certain skill sets were expected to be covered. For example, accounting, management, and business policy were all listed as required items. These requirements set forth were implemented rather rapidly, showing the dedication of the recognized institutions.

In fact, in 1981 a study was mailed to 208 AACSB deans. Of the 203 returned, only five classes did not have a business policy course. This addition was a significant change, because as of 1931, there was essentially no business policy requirement (Eldredge \& Galloway, 1983). Since its implementation, the use of a policy course has traditionally been at the senior level (96.5\% of the 1983 Eldredge survey). The policy course is frequently the capstone experience in business degrees. Assessments such as this (at the end of the student's academic career) can provide an opportunity for summative assessment which helps the faculty and administration improve the program, but provide no opportunity for student to reflect on individual performance (Maki, 2002). 
In 2000, Texas A\&M created a course-embedded assessment program that had clear objectives and objective-specific questions integrated into assessments and assignments. The primary motivation for the program was the increased AACSB assessment emphasis (AACSB, 2003). Course-embedded assessments generally provide direct feedback to students and allow them to improve their individual skills (Palomba \& Banta, 1999). In addition, formative assessment data can be used to provide feedback and to make updates to the program (Terenzini, 1997). ACBSP and IACBE also require accredited members to state their assessment plans. ACBSP (2004b) requires business programs to have a process in place to set directions for student learning and program performance. IACBE (2005) requires the business unit to have a strategic plan that is driven by a clearly defined mission and broad-based goals

\section{Principle 4}

Assessment requires attention to outcomes, but also and equally to the experiences that lead to those outcomes. The outcomes and the experiences leading to the outcomes (both inside the classroom and as a result of their student life) should be considered. Using Astin's conceptual model for assessment (see Figure 2.2), the relationship among inputs and environments and experiences to the outputs is easily visualized.

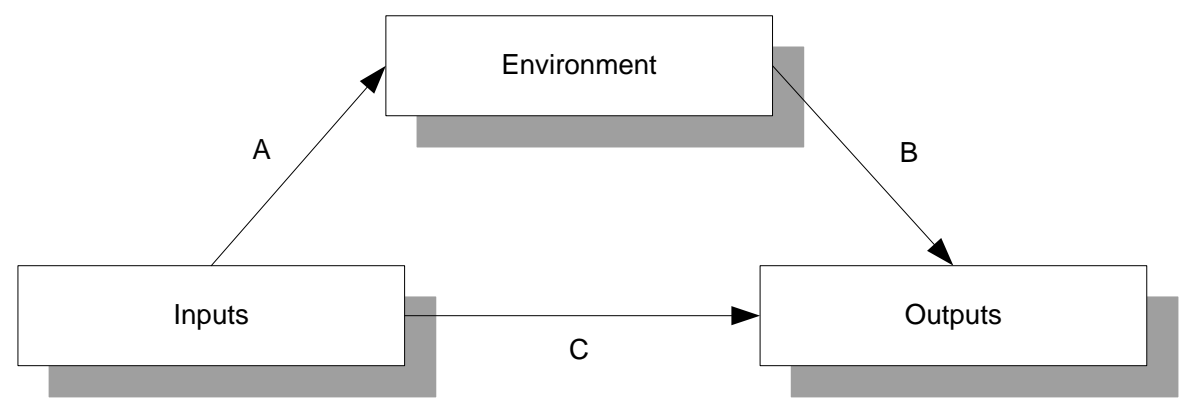

Figure 2. Astin's IEO Model

Note. From Astin, 1991, p. 18. 
In Astin's model, inputs are the "talents" a student brings to the educational program and outputs are the "talents" that are being developed by the program. The environment includes "those things that the educator directly controls in order to develop the student's talents" (Astin, 1991, p. 18). Astin found that "simply having input and outcome data of a group of students is of limited value if you do not know what forces were acting on these students during the same period of time" (p. 20). In Astin's model, assessment is concerned with the relationship between the effects of environmental variables, or experiences, on outcome variables, as depicted by relationship line B (Astin, 1991).

AACSB, beginning in their 1991 standards, identified the importance of this statement through a focus on educational activities and their quality (Henninger, 1994). In a random (stratified) survey of 573 business faculty, Michlitsch and Sidle (2002) found that almost half (48\%) of all business faculty focused their method of determining student learning on both the process that students use and the outcomes students obtain. Although no specific information was available detailing ACBSP's and IACBE's focus on the activities and experiences leading to learning, ACBSP (2004b) expected business schools to design learning environments taking into account student needs and IACBE (2005) expected the delivery of course content to be appropriate, effective, and to stimulate learning (IACBE, 2005).

\section{Principle 5}

Assessment works best when it is ongoing, not episodic. Assessment should be ongoing, not episodic. Assessment, very like the Total Quality Management (TQM) and Continuous Improvement movements in business, requires a dedicated on-going effort and a feedback loop to complete the cycle. This process, as explained by Huba and Freed (2000), is shown in Figure 3. Too often, assessment is conducted as the time for accreditation approaches. This compliance 
approach uses an external motivator. A better approach is when the faculty and professional staff seek to answer questions in an on-going process (Maki, 2002). In a study of accounting programs, Lusher (2006) found that only $58 \%$ of baccalaureate programs reported involvement in on-going assessment activity. Bennion and Harris (2005) found that integrating assessment with other ongoing performance improvement efforts enhances the long-term viability and usefulness of the assessment program.

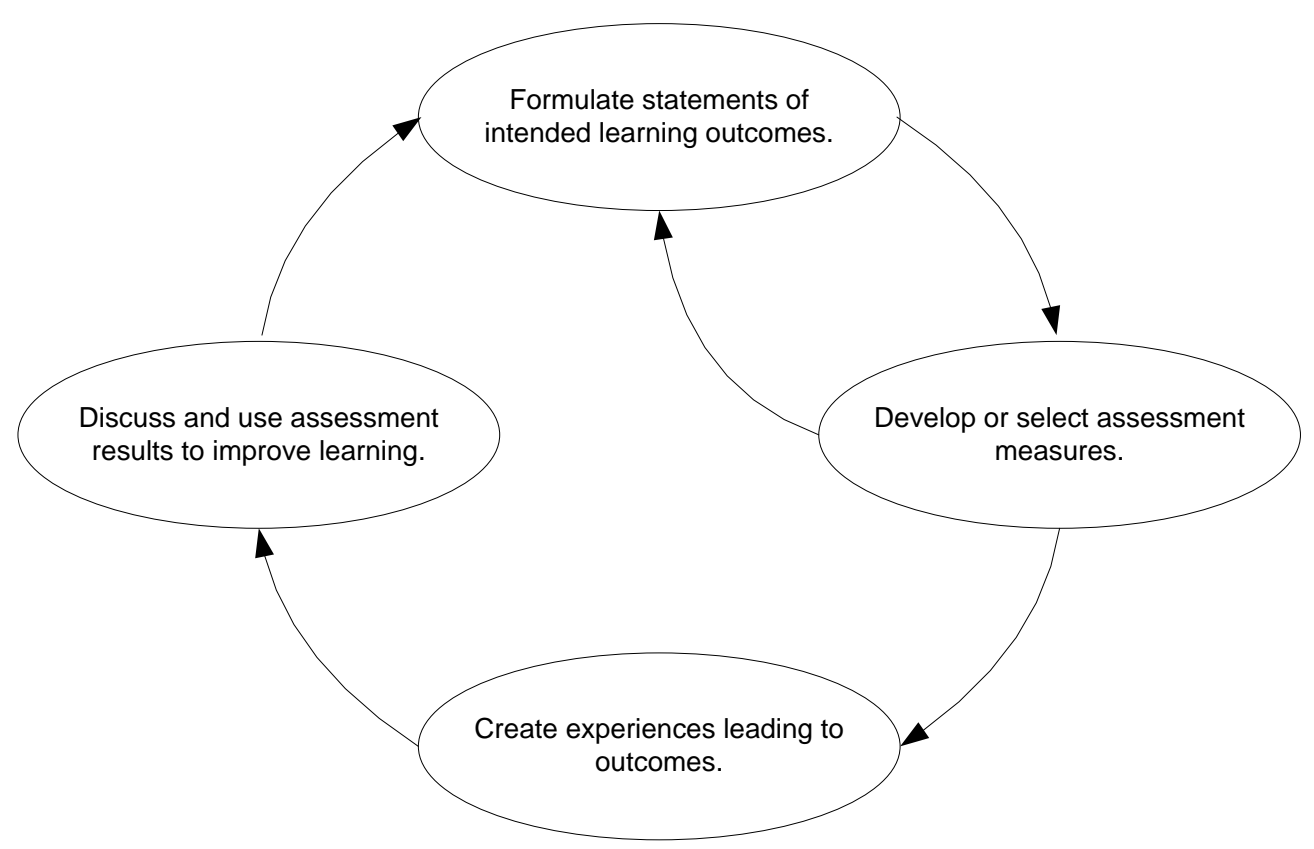

Figure 3. Huba and Freed's Assessment Process

Note. From Huba and Freed, 2000, p. 10.

All three business accrediting bodies require assessment to be a continuous process (AACSB, 2005; ACBSP, 2004b; IACBE, 2005). IACBE (2003) stated that "the Outcomes Assessment Process is the most important component of IACBE accreditation” (p. 7). 


\section{Principle 6}

Assessment fosters wider improvement when representatives from across the educational community are involved. Assessment should be cross-sectional and should involve all levels of classes and all levels of cognitive ability, as well as all subject areas. One process to meet this objective is to use curricular and co-curricular mapping. This process has representatives from across the institution identify the depth and breadth of opportunities in and outside the classroom that intentionally address the development of desired outcomes (Maki, 2002). Huber and Morreale (2005) pointed out that although there are differences in disciplines, the scholarship of teaching and learning grows in the sharing of information across disciplines. Involvement in assessment programs should include key personnel from the institution, and most important are the faculty (Banta, Lund, Black, \& Oblander, 1996). All three accrediting agencies indicate the importance of faculty-developed assessment instruments and learning outcomes (AACSB, 2005; ACBSP, 2004b; IACBE, 2005). In fact, AACSB used the words “deep involvement” (2005, p. 60) to describe the level of involvement faculty should play in the assessment efforts. In addition to institutional representatives, assessment should involve external groups, including parents, employers, and accreditation bodies (Banta et al., 1996). Krug (2005), in an ad hoc survey of AACSB accredited business schools, found that when the guidelines used by faculty to develop course-level assessment programs was based more on the business school and institution, rather than the department and the individual, greater importance was placed on assessing the measure of knowledge of subject area and critical thinking skills. 


\section{Principle 7}

Assessment makes a difference when it begins with issues of use and illustrates questions that people really care about. Assessment should focus on the important issues of student learning and highlight those areas in ways that are easy for others to understand. As Ewell (2003) noted, "building an assessment culture is less about engaging in 'scientific' measurement and more about determining the most important questions to ask" (p. 32). In the instance of this principle, accreditation provides a method for providing answers to the important questions. CHEA has identified three issues of importance for those seeking additional information about higher education institutions. These questions are a.) How does accreditation work? b.) What are the assets and the weak points of the institutions or program in which I am interested? and c.) What skills and capacity can enrollment in your institution or program help me to achieve? (Eaton, 2004).

Assessment results should be disseminated to stakeholders. Jones and Voorhees (USDE, 2002), in a cross-site analysis of eight institutions with successful competency-based initiatives, found publicly sharing assessment results to be a strong strategy for sustaining education initiatives. Specifically, they believed that results should be shared on a regular basis with stakeholders and that the intended audiences were capable of interpreting the results in a meaningful manner. Virginia Tech's Pamplin College of Business ensures assessment data are used by making it public, sharing it with all the faculty in the department, making it part of the department head's annual review with the dean, as well as part of the dean's annual meeting with the faculty. In addition, the report requires action items based on the data and updates on older items (Palomba \& Palomba, 2001). 


\section{Principle 8}

Assessment is most likely to lead to improvement when it is part of a larger set of conditions that promote change. Assessment should be integrated into existing processes at the institution similarly to any other plan or policy. The assessment results should be used in developing curriculum, institutional planning, program review, and other decision-making on campus (Huba \& Freed, 2000). Assessment is oriented toward change and should address items that can be changed and will have a positive impact on the institution or program (Pike, 2002). AACSB (2005) believed that by measuring student learning, the school and faculty members can improve the program and courses. ACBSP (2004b) required statements describing the selection and use of results, as well as a continuous process improvement analysis of the student learning and performance. This analysis reviews the student learning and performance process, the evaluation method, and finally the changes or modifications made based on assessment results.

IACBE (2005) characteristics of excellence in business education indicate that the outcomes assessment process should promote continuous improvement and is linked to the strategic plan. Linking assessment and improvement, as well as identifying how the assessment data are utilized, is potentially the "most critical aspect of successful assessment practice" (Banta, Lund, Black, \& Oblander, 1996, p. 50). Teams of evaluators for accreditation agencies are instructed to review the comprehensiveness of skills and knowledge taught at institutions, multiple sources of student performance, multiple dimensions of student performance (not just a summative grade), and the directness of assessment to ensure that the evidence is more than just a self-report (CHEA, 2002).

At Virginia Polytechnic Institute and State University in the Department of Management, the faculty reviewed assessment data from a case study and found that students needed more 
emphasis in communication. They responded by holding a workshop, lead by a colleague from the English Department, to show faculty how to integrate writing into the curriculum (Banta, et al 1996). The College of Business at Ball State has been involved in assessment efforts for over 15 years and has also made significant curriculum changes. After a through review of assessment and courses, Ball State now requires multiple-level assessment including pre- and post-testing. It also has course-based assessment in its business core and test that foundation knowledge in the capstone course. The changes that have occurred at Ball State include adding complete courses to its required curriculum and redesigning its individual courses, as well as entire programs (Palomba, 1997).

Principle 9

Through assessment, educators meet responsibilities to students and to the public. The Association of American Colleges and Universities (AAC\&U) board of directors created a framework for accountability that has ten recommendations (2004). The AAC\&U report stated that "it is not enough for an institution to assess its students in ways that are grounded in the curriculum; colleges and universities must provide useful knowledge to the public about goals, standards, accountability practices, and the quality of student learning" (p. 9). The ten recommendations complement, and at times duplicate, the principles of good practice discussed in this chapter. According to AAC\&U, 2004), they include:

1. Make liberal education the new standard of excellence for all students;

2. Articulate locally owned goals for student learning outcomes;

3. Set standards in each goal area for basic, proficient, and advanced performance;

4. Develop clear and complementary responsibilities between general education and department programs for liberal education outcomes; 
5. Charge departments with responsibility for the level and quality of students most advanced work;

6. Create milestone assessments across the curriculum;

7. Set clear expectations for culminating work performed at a high level of accomplishment;

8. Provide periodic external review and validation of assessment practices and standards;

9. Make assessment findings part of a campus-wide commitment to faculty inquiry and educational improvement; and

10. Provide public accountability and transparency. (pp. 11-12)

Assessment is shaped by both the internal interests of the institution and the external needs (Palomba \& Banta, 2001). Among these stakeholders are accrediting agencies (regional and professional), government bodies, alumni, employers, students, faculty, staff, and others. Prichard, Potter, and Saccucci (2004) found that "to be effective, an outcomes assessment program much match stakeholders and their goals" (p. 153). Students can get immediate benefit from assessment as they transform themselves into the business professionals schools desire. Assessing student learning over time is known as formative assessment. Formative assessment allows students to understand their strengths and weaknesses and reflect on methods of improvement (Maki, 2002). Regional accreditation agencies all require member institutions to collect and use assessment data for improving their institutions, although the processes are not mandated. There is a shift within many disciplinary accrediting bodies from input-based accreditation to student learning outcomes (Palombo \& Banta, 2001). In addition to, or perhaps as a result of, the public demand for standards, some states are also focusing on student learning 
outcomes (Palombo \& Banta 2001). In fact, Louisiana and Pennsylvania require specialized business accreditation for some of their public institutions (McTaggart, 2005).

The call for public accountability and engagement is not new to higher education. In the mid-1980s and early 1990s, the National Policy Board for Institutional Accreditation had an agenda to make review results more public (Ewell, 1998). In 1986, assessment efforts were more likely to be undertaken based on state government pressures than for curriculum reform (ElKhawas, 1986, cited in Assessment in Practice, 1987, p. 57 ).

Regardless of the demands of accountability and the compelling reasons for assessment, effective outcomes assessment is an important component in demonstrating institutional accountability (Banta, Lund, Black, \& Oblander, 1996). CHEA suggested in response to the challenge of providing information to the public that accrediting organizations and CHEA can provide communication at a basic level explaining accreditation to students and the public. In addition, CHEA provided examples and summary reports to further assist institutions, students, and the public (Eaton, 2004). Because the public is not familiar with specialized accreditation, AACSB is developing marketing materials to explain to stakeholders the importance of accreditation (Sorensen, 2005).

\section{Conclusion}

As the discussion of the nine principles indicates, there has been some integration of the principles into the accreditation standards of each of the three business accreditation agencies. Business schools are striving to meet the objectives for assessment set by their accreditation agencies. This study sought to identify the degree to which accredited business schools follow the best practices in assessment on an ongoing basis and if assessment has had an impact on the success of business schools. In addition, the relationship of assessment and accreditation within 
the business units shows the degree of influence accreditation has on assessment efforts and if either would exist without the coexistence of the other. Although no comparison was made of status or quality of the three accreditation agencies, this study sought to discover if there is any variation in outcome assessment practices utilized by a business school based on its affiliation with an accreditation body. 


\section{Definition of Key Terms and Concepts}

Accreditation. An important and constructive form of quality assurance (Bogue, 1998).

Assessment. The systematic collection, review, and use of information about educational programs undertaken for the purpose of improving student learning and development (Palomba \& Banta, 1999).

Core Business Classes. The courses that all business students are required to take (Palomba \& Palomba, 1999). The approach to curriculum in which knowledge should be compartmentalized into courses; courses are integrated into the core; and cores are combined into curricula. Business schools are typically organized into functional departments of accounting, finance, marketing, management, and so forth (Walker \& Black, 2000).

Direct Assessment Measures. A measure of student learning that requires students to apply their knowledge and skills as they complete the activity or instrument (Palomba \& Banta, 1999).

Faith-based Accreditors. Accredit religiously affiliated and doctrinally based institutions, mainly nonprofit and degree-granting (Eaton, 2006). Formerly grouped into National Accreditors (Eaton, 2003)

Goals (Program-Level). Items that are identified and indicate what a department stands for or intends to accomplish. These are used by programs as "tools to focus energy and commitment" (Wergin, 2003, p. 107). 
Indirect Assessment Measures. An activity or instrument that asks students to reflect on their learning rather than demonstrate their skills or knowledge (Palomba \& Banta, 1999).

National Accreditors. Accredit public and private, nonprofit and for-profit, frequently singlepurpose institutions, including distance learning colleges and universities, private career institutions, and faith-based colleges and universities (Eaton, 2003). As of 2006, this grouping is broken into Faith-Based and Private Career Accreditors.

Private Career Accreditors. Accredit mainly for-profit, career-based, single-purpose institutions, both degree and non-degree (Eaton, 2006).

Specialized or Programmatic Accreditors. Accredit specific programs, professions, and freestanding schools, e.g., law, medicine, engineering, and health professions (Eaton, 2003, 2006).

Regional Accreditors. Accredit public and private, mainly nonprofit and degree-granting, twoand four-year institutions (Eaton, 2006).

Reliability. The degree to which a consistent response is elicited (Suskie, 1996, p. 52).

Standards. "Standards are consensus documents" (Davenport, 2001, p. 69) They are the guidelines an agency uses to determine if institutions receive accreditation. They are the 
benchmarks or point of comparison against which accreditors compare collected evidence to determine eligibility for accreditation (Wergin, 2003).

Student Learning Outcomes The knowledge and ability that students have after instruction that they didn't know or couldn't do before the instruction (Huba \& Freed, 2000).

Triangulation. There are multiple instances that support a claim, and therefore provides a "richer portrayal of student learning" (Hernon, 2004, p. 150).

Validity. The degree to which a measurement accurately measures what it is intended to measure (Suskie, 1996). 


\section{Summary}

This chapter has outlined the literature relevant to the research questions and the study of assessment and accreditation. Chapter 3 describes the research design that was used to explore the research questions, including the research methods, a description of the participants, data collection procedures, and analysis. A conclusion summarizes the major points from previous sections. The Appendices contain the cover letter and the instrument used with participating business schools. 


\section{CHAPTER 3: METHOD}

\section{Overview}

This study used quantitative methods to gather information regarding the use of assessment in accredited undergraduate business schools. A survey instrument was used to explore the degree that business schools participate in effective assessment, the assessment practices which have an impact on the success of the business school, and the similarities and differences in assessment practices by their accrediting body. A survey was chosen as the preferred method of data collection to ensure that specific points may be targeted and also because of "the rapid turnaround in data collection" and "economy of design" (Creswell, 2003, p. 154).

\section{Population}

The results of this study are a census of accredited undergraduate schools of business. A census was chosen because the total number of business schools having accreditation was less than 1,000. A survey instrument (see Appendix A) was developed and used to gather descriptive information about current assessment and accreditation status in academic business units at the undergraduate level. The survey was a comprehensive instrument that examined the entire business unit, and questions were answered with regard to the entire unit's activities. Institutional and unit demographics were collected. Although the information collected showed the functional content areas within the unit, the focus of the study was the overall business academic unit. This research provides a baseline for comparison of the utilization of assessment by accredited business schools and can be used to discuss the state of accreditation and assessment affairs in the academic business area as a whole. The researcher obtained mailings lists from the three accrediting agencies for business units, the Association to Advance Collegiate Schools of 
Business (AACSB), the Association of Collegiate Business Schools and Programs (ACBSP), and the International Assembly for Collegiate Business Education (IACBE). The survey was sent to the attention of the assessment or accreditation contact at each college or school of business, as listed in mailing lists obtained from each of the three specialized accreditation agencies.

\section{Research Design}

Quantitative methods were used to describe the state of assessment efforts in accredited business units and to examine the similarities and differences in activities by accrediting body. To answer the research questions, a survey was developed specifically targeting the goals of this study. An overview of the survey is presented initially and then specific items are discussed in relation to each research question including justifications from the literature. The developed survey has five parts including: Institution Demographics, Academic Unit Demographics, Assessment Development, Assessment Details and Learning Outcomes, and Assessment Success Indicators. The first demographical section collected institutional information including the type of institution, the focus of the institution, the age of the institution, the number of students at the institution, the regional accreditation status of the institution, and the presence of a clear institutional mission (see Appendix A, questions 1 through 7). In addition to asking for specialized accreditation status, the second demographical section, focusing on the academic unit demographics, asked for data specific to the business unit such as information on the degrees awarded including the number of degrees awarded and the types of degrees offered, the number of faculty (full- and part-time), the number of students, and the presence of a unit mission (see Appendix A, questions 8 through 17). Next, the assessment development section asked questions concerning the institution and unit's commitment to assessment and accreditation, the assessment plan's development, and application of assessment results (see Appendix A, questions 18 
through 36). Specifically, the section sought to find out the maturity level of assessment plans in schools of business and the level of activity associated with assessment. The fourth section asked questions concerning the assessment details including the scope and intent of the assessment efforts. The influences on assessment plan revisions, direct and indirect assessment methods, and actual practices were covered in this section (see Appendix A, questions 37 through 84). The final section of the survey asked eight questions about the degree to which assessment efforts have influenced the success of students, graduates, and the curriculum (see Appendix A, questions 85 through 93). Success, here, was divided in to two areas. First, it was measured by the positive contribution toward the attainment of passing grades, the securing of internships, graduation rates, and graduates' abilities to obtain a job in their chosen field and their job performance. Second, success was defined by the positive influences the assessment plan has had in curriculum updates or revisions, the ability to achieve and sustain accreditation, and the perceived improved quality. Finally, this section asked a question pertaining to the level of impact an accreditation agency has on the assessment plan. Each of these sections provided information that allowed the researcher to answer the three research questions presented in Chapter 1:

1. To what degree do accredited business schools follow the best practices in assessment?

2. To what degree does assessment activity impact the success of business schools?

3. Is there a significant difference in outcomes assessment practices utilized by business schools according to their accrediting body (by IACBE, ACBSP, and AACSB)? 
The relationship of research questions to survey items and the total number of survey questions that provided confirmation of the breadth of each research question (see Table 3). The analysis showed that $31.18 \%$ of the survey questions provided insight to the demographics of the participants, $45.16 \%$ gathered data focused on Research Question 1, 8.60\% focused on Research Question 2, and $68.82 \%$ of the questions provided details to answer Research Question 3. Details of the survey instrument and relevant research questions follow in the next sections.

Table 3

Survey Items by Research Question

\begin{tabular}{lcc}
\hline Research Question & Relevant Survey Items & Total Number of Questions \\
\hline Demographics & $1-6,8-16,28,29-32,33-36$, & 29 \\
& $81-84,93$ & \\
1 & $7,17,41,42,43-80$ & 42 \\
2 & $85-92$ & 8 \\
3 & $7,17,18-22,23-27,37-40,41$, & 64 \\
& $42,43-80,85-92$ & \\
\hline
\end{tabular}

\section{Demographic Information}

To gain insight into the population being surveyed, some descriptive questions were created. This information was helpful in describing the population. First, information on the institution was gathered via the instrument by questions 1 through 6 . These questions included:

1. What year was your institution founded?

2. Is your institution public or private?

3. What is your institution's main focus? Available options include: Research, Teaching, Service, and Other. 
4. How many students attend your institution (total at all campuses)?

5. Is your institution regionally accredited?

6. If yes, please indicate which agency and date of most recent review (Month/Year). Available options included the eight regional accrediting agencies in the United States.

Second, information about the business unit was gathered by the following questions:

8. Throughout the survey "academic unit" or "unit" is used to describe the academic business unit. What is your unit? With the available options of College of Business, School of Business, Department of Business, and Other.

9. Is your academic unit accredited by a specialized accreditation agency?

10. If yes, indicate your specialized accreditation(s), the date awarded (Month/Year), and the last review date (Month/Year).

11. How many full-time faculty are there in your academic unit?

12. How many part-time faculty are there in your academic unit on average each semester?

13. How many students are currently enrolled in your academic unit?

14. On average, how many graduates per academic year does your academic unit award degrees in each level below? Levels include Associate, Bachelor, Master, and Doctorate.

15. For each distinct degree listed below, please indicate the levels of education you offer in your unit. Please count only if it is an actual degree. For multiple majors within a general business degree - count as general business. Available options include: Accounting, Business Education, Computer Information/Management 
Information Systems, Economics/Managerial Economics, Finance (includes Banking), General Business/Business Administration, Management, Marketing, and Other.

16. For a general bachelor-level degree in Business/Business Administration, what majors do you offer? (Check all that apply.) Options include: Accounting, Business Administration, Computer Information Systems/MIS, Ebusiness/commerce, Economics/Managerial Economics, Entrepreneurship/Small Business Admin., Finance (includes Banking), Hotel/Restaurant/Tourism, Human Resource Management, Insurance, International Business, Management, Marketing, Production/Operations Management, Real Estate, Supply Chain Management/Logistics, Other.

The next demographic information gathered was about the assessment plan and included: 28. Which of the following best describes your assessment plan and assessment efforts to date? Available options include: No plan and not planning to create one, No plan but beginning to develop a plan, Planned but not implemented, Early implementation state with no assessment results, beginning to review early assessment results, reviewing assessment results and beginning to formulate action plans, Implementing actions based on assessment results, and Assessment plan is reviewed and changes have been made consistently to the plan over time.

Questions 29 through 32 focused on the development and responsibility of the assessment plan. Specific questions were:

29. Who developed your plan?

30. Who is responsible for your plan updates? 
31. Who is responsible for monitoring assessment plan efforts?

32. Who is responsible for reporting results of assessment activities?

The options to respond to these four questions include Faculty Member, Faculty Committee, Administrator, Administration Committee, Joint Committee, and Other.

Question 33 asked for the single largest motivator in the creation of the plan. The available choices were: Regional accreditation agency, Business unit decision, Institution policy or recommendation, Specialized accreditation agency, Faculty advocate, and Other. The question read:

33. What was the largest single motivator in the creation of your assessment plan? (Please select only one.)

Question 34 asked for any and all resources used in the development of the assessment plan. The specific question was:

34. Which of the following did you use to facilitate the development of your plan? (Please select all that apply.) The options available included Institution guidelines, Faculty expertise, Regional accreditation outlines, External consultants, Internal consultants, Specialized accreditation outlines, and Other institution resources with an area for indication of the specific resource.

Questions 35 and 36 asked the years of development and updating of the plan. Specific questions were:

35. In what year did you begin to implement this plan?

36. In what year did you most recently update your plan? 
Questions 81 and 82 sought to find the automation of assessment in an academic unit. Question 81 asked how frequently computer resources were in use in assessment and question 82 asked for the type of package in use with the options of Spreadsheet (Excel, etc), Database (Access, etc), and Other with an area for write in packages. The actual questions were:

81. How frequently does your institution currently use computer resources to monitor your assessment efforts?

82. If so, what package(s)?

Question 83 asked where faculty discussed assessment results and question 84 asked the methods that were used for the distribution of assessment results. The questions were:

83. Where do faculty discuss assessment results? (Check all that apply.) Available selections include Faculty Offices, Regular Unit Meetings, Formal Retreats, and Other Locations.

84. What methods have you used to distribute your assessment results? (select all that apply) Possible answers include Web Site, Newsletter, Bulletin Board, Presentation, Postal Mail, and Other.

The final demographic-related question inquired the degree of influence the accreditation agency has had on the assessment plan. The specific question was:

93. To what degree do you believe your efforts required by or for your accreditation agency have influenced your assessment plan? A Likert scale ranging from Very High to Very Low is provided to answer this question. 


\section{Research Question 1}

To what degree do accredited business schools follow the best practices in assessment?

To examine the degree accredited business schools followed the best practices in assessment, the best practices were reviewed and questions were distilled from the Nine AAHE Principles of Good Practice in Assessment.

Principle 1. The assessment of student learning begins with educational values (AAHE, 1992).

For this principle, two survey questions were developed to investigate the mission of the institution and the business unit. Questions 7 and 17 focused on the presence or absence of a mission through a Likert scale ranging from Very Clear to Not Clear at all. The questions were:

7. To what extent does your institution have a mission that is clear and apparent on your campus?

17. To what extent does your unit have a mission that is clear and apparent on your campus?

Principle 2. Assessment is most effective when it reflects an understanding of learning as multidimensional, integrated, and revealed in performance over time (AAHE, 1992).

The first two questions that addressed this principle were questions 42a and 42b. These two questions asked for the frequency of specific direct and indirect methods. The frequency was measured on a five-item Likert scale ranging from very frequently to never. Direct assessment items that were assessed included:

Written Examinations (approximately 1 hour or more)

Quizzes (brief assessment, less than 1 hour)

Commercially developed exams (such as ETS Major Field Tests) 
Oral Examinations

Written Problems

Thesis or Term Papers

Projects

Case Studies and Simulations

Presentations

Portfolios

Internship or Practicum Evaluations

Indirect assessment items that were listed included:

Reflective Papers and Journals

Entrance Interviews

Exit Interviews

Focus Groups

Employer Surveys

Student Satisfaction Surveys

Alumni Surveys

Course Evaluation

In addition, for each question, participants could select the "Other" category by writing in the specific assessment and rating the frequency of use.

Questions 41, 59, 61, 62, 63, 66, 67, and 68 also provided insight to the general use of this principle using a Likert scale to gauge the degree of the relationship through agreement with a particular statement. The scale included the five options of Strongly Agree, Agree, Neutral, Disagree, and Strongly Disagree. The statements were: 
41. How often do you use rubrics, or defined levels of performance, in assessment?

59. My unit's assessment plan measure multiples learning objectives and skills.

61. Students are assessed at multiple points in their academic career.

62. Assessment is integrated across a "core" business curriculum.

63. The individual functional areas within the Business academic unit (Accounting, Management, etc.) perform assessment.

66. Assessment efforts measure affective skills (feelings, preferences, values).

67. Assessment efforts measure cognitive skills (thinking, evaluating, analyzing).

68. Assessment efforts measure psychomotor skills (physical, perceptual).

Principle 3. Assessment works best when the programs it seeks to improve have clear, explicitly stated purposes (AAHE, 1992).

Questions 48, 50, 51, 52, 53, and 60 focused on the purposes of assessment and the level of connection between the mission statements and the academic unit learning outcomes. These questions used a Likert scale to gauge the degree of the relationship through agreement with a particular statement. The scale included the five options of Strongly Agree, Agree, Neutral, Disagree, and Strongly Disagree. The statements were:

48. The assessment plan in my unit has clearly stated values.

50. The assessment plan provides clear, explicit student learning outcomes.

51. Objective measures and skill assessments are stated clearly in the plan.

52. Outcomes in my academic unit are connected to the academic unit's mission, vision, and goals.

53. Outcomes in my academic unit are connected to the institution's mission, vision, and goals. 
60. The assessment plan indicates the goals of individual assessment activities.

Principle 4. Assessment requires attention to outcomes but also and equally to the experiences that lead to those outcomes (AAHE, 1992).

As explained in Chapter 2, Astin defined the environment to be things under the control of the faculty. His input-environment-output model shows how assessment is concerned with the forces acting on the student at the time of learning and relationship between student environment, or experiences, on learning outcome achievement (Astin, 1991). Questions 69, 70, 71 , and 75 on the survey instrument addressed the environmental controls in the assessment process. These questions used a Likert scale to gauge the participant's agreement with a statement. The scale included the five options of Strongly Agree, Agree, Neutral, Disagree, and Strongly Disagree. The statements were:

69. Assessment efforts consider the student experiences not just the results.

70. Curriculum content is considered in the assessment planning process.

71. Teaching styles are considered in the assessment planning process.

75. Assessment result uses are considered when the activities are planned.

Principle 5. Assessment works best when it is ongoing not episodic (AAHE, 1992).

There were four questions, $72,73,79$, and 80 , that addressed assessment as a continuous process. These questions were statements which participants indicated their level of agreement using a five option Likert scale. The available choices included Strongly Agree, Agree, Neutral, Disagree, and Strongly Disagree. The statements were:

72. Assessment in my unit is an on-going continuous improvement process.

73. The assessment process itself is evaluated periodically. 
79. Assessment results are compared over time and verify progression toward academic unit goals.

80. Improvements are made based on assessment results.

Principle 6. Assessment fosters wider improvement when representatives from across the educational community are involved (AAHE, 1992).

Questions 44, 54, 58, and 74 examined involvement in assessment beyond the instructorlevel. These questions made statements about assessment and participants selected from five choices using a Likert scale. The options were Strongly Agree, Agree, Neutral, Disagree, and Strongly Disagree. The statements included:

44. The assessment efforts are a campus-wide initiative.

54. Classes in my unit have outcomes developed because the unit faculty as a whole feels it is important, it is not an individual faculty effort.

58. Outcomes in my academic unit are developed by faculty collaboration by discipline

74. Individuals from beyond the campus community are involved in assessment (alumni, employers, etc).

Principle 7. Assessment makes a difference when it begins with issues of use and illustrates questions that people really care about (AAHE, 1992).

Question 47 ensured that assessment focused on the important issues of student learning relevant to the unit. This question, when combined with questions 55, 56, and 77 provided the basis for determining if a unit was focusing on the important issues and highlighting them for students and the public. These questions used a Likert scale with the options of Strongly Agree, Agree, Neutral, Disagree, and Strongly Disagree to evaluate the following statements: 
47. Assessment efforts measure items that are important and relevant to the unit's decisions.

55. Outcomes in my academic unit are learner-centered and linked to significant aspects of learning and achievement.

56. Outcomes in my academic unit are focused on improving learners' knowledge.

77. Assessment results are reported and shared with all of the business faculty.

Principle 8. Assessment is most likely to lead to improvement when it is part of a larger set of conditions that promote change (AAHE, 1992).

Questions 45, 46, 64, and 65 also used a Likert scale with Strongly Agree, Agree, Neutral, Disagree, and Strongly Disagree options to respond to statements. The statements focused on the larger picture of faculty motivation for assessment and the assessment culture. The statements were:

45. Assessment is part of my unit's culture, not just performed around accreditation, or another external motivator.

46. My unit provides incentives for faculty to participate in assessment efforts.

64. Assessment is integrated into our strategic plans.

65. Assessment is integrated into our internal academic program reviews.

Principle 9. Through assessment, educators meet responsibilities to students and to the public (AAHE, 1992).

Question 43 inquired about the importance of quality teaching and learning. Question 49 ensured that goals of assessment were shared with others. Questions 57, 76, and 78 discussed communication with students and public. These five questions were asked in the form of 
statements which participants used the now familiar Strongly Agree, Agree, Neutral, Disagree, and Strongly Disagree Likert responses. The statements included:

43. The quality of teaching and learning is important on my campus.

49. Assessment goals are shared with others.

57. Outcomes in my academic unit are clearly communicated to the learners.

76. Assessment results are reported to students.

78. Assessment results are shared with the public.

To provide content validity, and ensure that the questions adequately assessed the intent of the 9 Principles, a panel of experts was assembled. The panel of individuals reviewed the survey questions developed for Research Question 1. Overall, the panel was in agreement with the questions proposed under the principles. Some specific feedback included:

"I believe you did a really good job of matching the questions with the goals they represent. I think you have interpreted the principles accurately."

"I think the survey is well designed. The items seem aligned appropriately with the construct characteristics of the nine principles. Well done.”

One panel member felt that the survey was "a little too narrow" and made some suggestions for expansion and but did not indicate that any questions were out of line with the principles they represented. All the panel members made some suggestions for improvement and the following changes were made to the instrument based on their input:

Questions 7 and 17 were revised to read "To what degree is your institution/unit mission reflected within the stated outcomes or assessment activities of your institution/unit?"

The word "skills" was removed from question 59. 
Question 75 was revised to read "The purpose of assessment is considered when assessment activities are planned."

Question 41 was renamed question 42A and question 42 was renamed question 42B.

A question, New Number 41, was added and read "How often do you use rubrics, or defined levels of performance, in assessment?" With potential responses a scale of very frequently, often, occasionally, rarely, and never

\section{Research Question 2}

To what degree do assessment activities impact the success of business schools?

To answer Research Question 2, the final section of the survey asked questions relating to the success of students, graduates, and the curriculum. These questions sought to determine the level of influence assessment efforts have had in that success. Statements concerning the relationship of assessment efforts were made and participants were asked to use a Likert scale to respond to the statement ranging from Strongly Agree to Strongly Disagree. The statements were:

85. To what degree do you believe your assessment efforts have influenced students' ability to achieve passing grades in courses?

86. To what degree do you believe your assessment efforts have aided students' ability to secure internships?

87. To what degree do you believe your assessment efforts have positively influenced student graduation rates?

88. To what degree do you believe your assessment efforts have positively effected graduates' abilities to obtain a job in their desired field? 
89. To what degree do you believe your assessment efforts have positively impacted graduates' abilities and job performance?

90. To what degree to you believe your efforts in assessment have provided basis for updating your curriculum?

91. To what degree do you believe your assessment efforts have improved your unit's ability to achieve accreditation?

92. To what degree do you believe assessment is important to the quality and success of your business academic unit?

\section{Research Question 3}

Is there a significant difference in outcomes assessment practices utilized by business schools according to their accrediting body (IACBE, ACBSP, and AACSB)?

To answer the final research question, all non-demographic questions $(7,17,18-27,37$ 40, 41, 42, 43-80, and 85-92) were reviewed for significant differences by accreditation body. Participants indicated their business accrediting organization in question 10.

Questions 18-27 query assessment commitment and accreditation commitment. The responses used the five option Likert scale of Strongly Agree, Agree, Neutral, Disagree, and Strongly Disagree to respond to the following statements:

Assessment Commitment:

18. The administration at my institution is committed to assessment.

19. The administration of my academic unit is committed to assessment.

20. The faculty in my academic unit are committed to assessment.

21. Faculty are provided incentives to participate in assessment activities.

22. Faculty resist assessment efforts. 
Accreditation Commitment

23. The administration at my institution is committed to accreditation.

24. The administration of my academic unit is committed to accreditation.

25. The faculty in my academic unit are committed to accreditation.

26. Faculty are provided incentives to participate in accreditation activities.

27. Faculty resist accreditation efforts.

Questions 37 through 40 asked the frequency of assessment plan revisions based on the accreditation agency, the institution, experiences, and results. The specific questions were:

37. How often have you revised your assessment plan based on recommendations from your specialized accreditation agency?

38. How often have you revised your assessment plan based on recommendations from your institution?

39. How often have you revised your assessment plan based on recommendations from your assessment experiences?

40. How often have you revised your assessment plan based on recommendations from your own findings?

Questions 7, 17, and 41 through 80 are explained under Research Question 1. These same questions were examined for differences by accreditation body.

Questions 85 through 92 are explained under Research Question 2. These same questions were examined for significant differences by accreditation body.

Because this research used the AAHE Principles of Good Practice in Assessment as a basis for investigation, an analysis of principle-related questions was constructed to determine 
the allocation of survey questions and ensure that the principles were adequately covered (see Table 4).

Table 4

Allocation of Survey Questions by Principle

\begin{tabular}{cc}
\hline Principle & Number of Questions \\
\hline 1 & 2 \\
2 & 9 \\
3 & 6 \\
4 & 4 \\
5 & 4 \\
6 & 4 \\
7 & 4 \\
8 & 4 \\
9 & 5 \\
\hline
\end{tabular}

A review of the number of questions per principle shows that there were between two and nine questions for each principle providing insight into the principles' application on campuses. Principle 1 had two questions, Principles 4, 5, 6, 7, and 8 had four questions each, Principle 9 had five questions, Principle 3 had six questions, and the largest principle was Principle 2 with nine questions directed toward it (see Table 4). 


\section{Data Collection}

In Spring 2007, information was collected directly from the accredited academic business unit participants (who were typically assessment or accreditation coordinators) through the use of the developed survey instrument. Before the all-inclusive mailing, a pilot study with five assessment contacts in accredited business schools was conducted after approval from the West Virginia University Institutional Review Board for the Protection of Human Subjects (IRB) to gain insight into the survey's use. Data from the pilot was used to refine the survey and increase the validity of the instrument (Suskie, 1996). Participants in the pilot study received a pilot cover letter with instructions on how to complete the pilot survey, the proposed research study cover letter, the proposed survey, and a pre-paid return envelope for the survey (see Appendix B). Approximately one week after the pilot participants received their packet of information, they were contacted to discuss their experiences with the survey (see Appendix C).

The pilot participants responded favorably to the survey in response to the questions regarding the clarity of the cover letter and the survey itself. Respondents indicated that it took an average of 13 minutes to complete the survey with a minimum completion time of 8 minutes and a maximum time of 20 minutes. The respondent who indicated the 20 minute interval also indicated that they had to look at information related to the questions before answering. Based on these responses, the revised cover letter indicated that it should take approximately ten to fifteen minutes to complete the survey.

Appropriate revisions were made to the survey instrument following the collection of pilot data and pilot survey responses. These revisions included a few minor editorial updates and some revisions in question wording. The following are the specific revisions made to the survey:

The dates in the letter were updated to reflect the mailing date. 
The cover letter was updated to include the words "for the protection of human subjects" and thus indicate purpose of the review.

The word "single" was added to question 3.

Responses to questions 29 through 32 were changed from option buttons to check boxes and the words "Select all that apply" were added at the top of the table.

The former "Joint Committee" option for questions 29 through 32 was revised to read "Both Faculty and Administration".

The words "with defined performance levels" were added to the new question numbers 42A and 42B.

Question 69 was revised to read "Student experiences are considered throughout the development of assessment activities.”

The words "and reported" were removed from question 77.

Questions 85 through 93 were updated to make it clear that the assessment efforts in question referred to the unit assessment activities, rather than the individual's efforts.

Minor grammar errors were corrected.

The footer date of the survey was updated to reflect the correct date for requested return.

The revised survey and cover letter were then mailed to actual research participants who were the assessment or accreditation coordinators within the colleges or schools of business. The cover letter explained the survey's purpose, reviewed the importance of the research, emphasized IRB approval from WVU, and thanked them for their time and cooperation with the research project (see Appendix D). Participants were asked to complete the survey and return it in a prepaid return envelope. Two weeks after the survey was mailed, a postcard reminder was sent to participants who had not responded to the initial mailing. A duplicate survey and a reminder 
letter was initially planned but due to restrictions from AACSB on the use of contact information, only the reminder postcard was possible.

In addition to the pilot and expert panel, there was some concern that larger institutions may not have a single person available to respond to the multiple parts of the survey. Prior to conducting the pilot survey, in order to determine the feasibility of a single study instrument, inquiries were made of five large, accredited, business units. The responses from this solicitation indicated that one person would be able to respond to the planned instrument and a single survey was the best method of collecting the needed data. In the actual communication, two questions were asked pertaining to the survey instrument itself and a final question inquired if they would be interested in serving as a pilot institution. Optional responses were provided for each question. The questions were:

1. If I sent a survey to your institution that asked general questions about undergraduate business assessment efforts, would a single person be able to answer those questions?

Yes, one person would be able to answer with that information

No, assessment plans determined at the specialized functional areas and no single person would be able to respond

2. Would you recommend that I send multiple surveys to your institution for distribution to allow different functional areas to respond separately?

Yes, send multiple copies

No, one would be best 
3. Would you be interested in participating in a pilot study of my survey instrument in the next month?

Yes, I would be interested

No, I would not be interested

Data Analysis

The responses collected were analyzed using the Statistical Package for the Social Sciences, SPSS. In some instances, simple frequencies provided a basis to answer questions concerning demographical information, specific use of assessment, and the relationship accreditation plays in assessment. Central tendencies were also used to analyze survey responses to try to identify single scores that represented each group of business units. The results of these calculations provided information to satisfy Research Question 1. Data correlations were computed to determine if there was a relationship between variables to answer Research Question 2. There were 96 such correlation values computed. In addition, to answer Research Question 3, data were analyzed using analysis of variance. The analysis of variance procedure conducted provides insight into differences by accreditation groups. Because there were multiple dependant variables, grouped by common purpose, a multivariate analysis of variance was conducted. Finally, individual dependant variable variances were reviewed.

Demographic Analysis

Institution (1-6) and Academic Unit (8-16) demographic questions were analyzed by frequency count. Frequencies were reported to provide a deeper understanding of the population participating in the survey.

Frequencies were determined by accreditation body for question 28 to show the level of assessment efforts in the unit. Questions 29 through 32 asked questions pertaining to the 
development and responsibility of the assessment plan. The options to respond to these four questions included Faculty Member, Faculty Committee, Administrator, Administration Committee, Joint Committee, and Other. A frequency of each response was conducted by accreditation body to determine the differences and similarities in plan development and responsibility.

Question 33 asked for the single largest motivator in the creation of the plan. The available choices were: Regional accreditation agency, Business unit decision, Institution policy or recommendation, Specialized accreditation agency, Faculty advocate, and Other. A frequency of each response was conducted by accreditation body to determine the primary assessment motivation in the unit.

Question 34 asked for any and all resources used in the development of the assessment plan. The options available included Institution guidelines, Faculty expertise, Regional accreditation outlines, External consultants, Internal consultants, Specialized accreditation outlines, and Other institution resources with an area for indication of the specific resource. Frequencies were also used to analyze this question. Each response was be totaled by accreditation body to determine the assessment plan influences.

Questions 35 and 36 asked the years of development and updating of the plan. The mean age of the assessment plan and mean time since updating the plan was calculated by accreditation body.

Frequencies of responses by accreditation body for questions 81 and 82 sought to find the automation of assessment in an academic unit and the frequency of responses by accreditation body. 
Question 83 was analyzed by frequency count to determine where faculty discussed assessment results. In addition, a frequency count by accreditation body of the six possible responses was used for question 84 to determine the methods used to distribute results of assessment activities.

Finally, question 93 asked the degree to which accreditation efforts have impacted assessment efforts. The means of the response were analyzed by accreditation body to determine the perceived level of impact of the different organizations.

\section{Research Question 1}

To what degree do accredited business schools follow the best practices in assessment?

Principle 1. To analyze this principle, the two survey questions ( 7 and 17) were analyzed to determine if the institution has a mission that is clear and apparent and if the unit has a mission that is clear and apparent on campus. The frequencies of responses were evaluated as well as the mean, based on corresponding values ranging from 5 to 1 (Very Clear to Not Clear at All).

Principle 2. Frequency and means analysis were used to determine the use of direct and indirect assessment methods and also the results of the remaining questions for this Principle. Each question $(41,42,59,61,62,63,66,67$, and 68) used a five-point scale, although the values of the text responses are different, they were quantified by the values of 1 through 5 and used comprehensively. The scales and their values are used throughout the remaining analysis (see Table 5). 
Table 5

Likert Response Possibilities for Survey

\begin{tabular}{lcccc}
\hline Value & & \multicolumn{3}{c}{ Likert Response Possibilities } \\
\hline 5 & Strongly Agree & Very Frequently & Very High & Very Clear \\
4 & Agree & Often & High & Somewhat Clear \\
3 & Neutral & Occasionally & Moderate & Neither Clear nor Unclear \\
2 & Disagree & Rarely & Low & Somewhat Unclear \\
1 & Strongly Disagree & Never & Very Low & Not Clear at All \\
\hline
\end{tabular}

Principle 3. Questions 48, 50, 51, 52, 53, 60 on the survey instrument were evaluated using frequency and means analysis to determine the extent Principle 3 is practiced.

Principle 4. Questions 69, 70, 71, and 75 were evaluated using frequency and means analysis to determine the extent the student experiences are considered in the assessment process.

Principle 5. Frequency and means analysis were conducted on the four questions that address assessment as a continuous process. The questions are: 72, 73, 79, and 80 .

Principle 6. Questions 44, 54, 58, and 74 were analyzed using frequency and means analysis to look for involvement in assessment representatives from across the educational community beyond the instructor-level.

Principle 7. The four questions for this principle were analyzed using frequency and means analysis. Questions 47, 55, 56, and 77 seek to find if assessment in the unit begins with issues of use and illustrates questions that people really care about.

Principle 8. There were four questions, 45 46, 64 and 65, that were analyzed using frequency and means analysis to see the extent that assessment is part of a larger set of conditions that promote change. 
Principle 9. Questions 43, 49, 57, 76 and 78 were analyzed using means analysis to determine the extent Principle 9 was used in business schools and, thus, the role assessment plays in meeting unit responsibilities to students and to the public.

\section{Research Question 2}

To what degree do assessment activities impact the success of business schools?

Eight questions in the last section of the survey (questions 85 through 92), relating to the success of students, graduates, and the curriculum, were analyzed using frequency and means analysis to answer Research Question 2. Success, as defined earlier, focused on the success of students, graduates, and the curriculum and the level of influence assessment efforts have had in that success. Additionally, a correlation of the frequency of assessment practices by principle and perceived success of a business unit was conducted. Specifically, 96 correlations were conducted. Variables for the correlation were Success and Principle where Success was comprised of the 8 success questions and Principle was the questions grouped by the 9 Principles. Mean responses to each of the eight success questions were correlated with mean responses to questions pertaining to each Principle. Because there were three parts to Principle 2, there were 11 total principle variables. Table 6, Map of Corresponding Components in Correlations, shows the 96 correlations and the questions included. Each of the 96 correlations is named in Table 6 using the numbers from 1 to 96, The variables are the column principle number and the row success question. For example, the first correlation is the mean response of question 85 and the mean responses of questions 7 and 17 and the second is the mean response to question 85 and the mean responses of question 41 . The presence of a high correlation indicates an increasing linear relationship between the two variables: the success of a unit and its assessment activities.. 
Table 6

Map of Corresponding Components in Correlations

\begin{tabular}{|c|c|c|c|c|c|c|c|c|c|}
\hline Principle & Question Numbers & 85 & 86 & 87 & 88 & 89 & 90 & 91 & 92 \\
\hline 1 & 7,17 & 1 & 2 & 3 & 4 & 5 & 6 & 7 & 8 \\
\hline 2 Direct & $42 \mathrm{a}$ & 9 & 10 & 11 & 12 & 13 & 14 & 15 & 16 \\
\hline 2 Indirect & $42 b$ & 17 & 18 & 19 & 20 & 21 & 22 & 23 & 24 \\
\hline 2 General & $\begin{array}{l}41,59,61,62,63,66,67, \\
68\end{array}$ & 25 & 26 & 27 & 28 & 29 & 30 & 31 & 32 \\
\hline 2 Overall & $\begin{array}{l}41,42 a, 42 b, 59,61,62,63 \\
66,67,68\end{array}$ & 33 & 34 & 35 & 36 & 37 & 38 & 39 & 40 \\
\hline 3 & $48,50,51,52,53,60$ & 41 & 42 & 43 & 44 & 45 & 46 & 47 & 48 \\
\hline 4 & $69,70,71,75$ & 49 & 50 & 51 & 52 & 53 & 54 & 55 & 56 \\
\hline 5 & $72,73,79,80$ & 57 & 58 & 59 & 60 & 61 & 62 & 63 & 64 \\
\hline 6 & $44,54,58,74$ & 65 & 66 & 67 & 68 & 69 & 70 & 71 & 72 \\
\hline 7 & $47,55,56,77$ & 73 & 74 & 75 & 76 & 77 & 78 & 79 & 80 \\
\hline 8 & $45,46,56,77$ & 81 & 82 & 83 & 84 & 85 & 86 & 87 & 88 \\
\hline 9 & $43,49,57,76,78$ & 89 & 90 & 91 & 92 & 93 & 94 & 95 & 96 \\
\hline
\end{tabular}




\section{Research Question 3}

Is there a significant difference in outcomes assessment practices utilized by business schools according to their accrediting body (by IACBE, ACBSP, and AACSB)?

Univariate analysis of variance (ANOVA) and multivariate analysis of variance (MANOVA) were used to test Research Question 3 in addition to frequency counts and means. Harlow (2005) states that ANOVA and MANOVA are statistical procedures that look for group differences and focus on the "ratio of the variance between means over the variance within scores" (p. 111). MANOVA is used when there are multiple dependent variables to determine the "differing means between groups" (Harlow, 2005, p. 106). To analyze the research question, the categorical independent variable, the accreditation body, was tested to see if there was a statistically different response to the dependent variables, the survey questions, by looking at the means of the questions broken down by independent variable (AACSB, ACBSP, and IACBE).

There were 16 MANOVAs conducted. For each MANOVA, the accreditation body served as the independent variable while the groups of questions will be the dependent variables. If the results of the MANOVAs indicated a significant model, then a closer examination of the individual ANOVAs for each item was conducted to determine where there are significant differences in assessment practices among the three accreditation bodies. The 16 MANOVA question sets were grouped based on the assessment principles, assessment and accreditation commitment, revision influences, and success indicators (see Table 7). 
Table 7

MANOVA Dependent Variable Question Sets

\begin{tabular}{|c|c|}
\hline MANOVA & Questions Included \\
\hline 1. Overall Principles 1-9 & (9 Principles Overall) \\
\hline 2. Principle 1 & 7, 17 (2 items) \\
\hline 3. Principle 2 Direct & 42a (12 items) \\
\hline 4. Principle 2 Indirect & 42b (9 items) \\
\hline 5. Principle 2 General & $41,59,61,62,63,66,67,68$ (8 items) \\
\hline 6. Principle 3 & $48,50,51,52,53,60$ (6 items) \\
\hline 7. Principle 4 & $69,70,71,75$ (4 items) \\
\hline 8. Principle 5 & $72,73,79,80$ (4 items) \\
\hline 9. Principle 6 & $44,54,58,74$ (4 items) \\
\hline 10. Principle 7 & 47, 55, 56, 77 (4 items) \\
\hline 11. Principle 8 & $45,46,64,65$ (4 items) \\
\hline 12. Principle 9 & $43,49,57,76,78$ (5 items) \\
\hline 13. Assessment Commitment & $18-22$ (5 items) \\
\hline 14. Accreditation Commitment & 23-27 (5 items) \\
\hline 15. Revision Influences & 37-40 (4 items) \\
\hline 16. Success Indicators & 85-92 (8 items) \\
\hline
\end{tabular}

Questions 7, 17, and 41 through 80 are explained under Research Question 1. These same questions were examined for differences by the independent variable, the three accreditation agencies. The nine Principles were evaluated using an overall MANOVA and 11 principle 
specific MANOVAs. The questions by principle or focus area served as the dependent variables, although Principle 2 had three MANOVAs due to extended responses provided in questions 41a and 41b. The first specific principle MANOVA used the dependent variables under Principle 1 (questions 7 and 17). Principle 2 evaluation consisted of three different MANOVAs. One MANOVA addressed question 41 and focuses on direct assessment methods with 12 items; another MANOVA addressed question 42 and focused on indirect assessment methods with 8 items; and the final MANOVA (pertaining to Principle 2) addressed general content including questions 59, 61, 62, 63, 64, 65, and 66). A MANOVA was conducted for Principle 3 (questions 48, 50, 51, 52, 53, and 60), and another MANOVA for Principle 4 (questions 69, 70, 71, and 75). Five additional MANOVAs were conducted for each of the following principles: Principle 5 (questions 72, 73, 79, and 80), Principle 6 (questions 44, 54, 58, and 74), Principle 7 (questions 47, 55, 56, and 77), Principle 8 (questions 45, 46, 64, and 65), and Principle 9 (questions 43, 49, 57,76 , and 78).

Questions 18 through 27 are statements showing assessment commitment and accreditation commitment. To analyze the level of commitment to assessment, two MANOVAs were used. The responses for questions 18 through 22 and the responses for questions 23 through 27 were the dependent variable in the MANOVAs. The data were analyzed on a 5 point scale where values were assigned to the Likert scale options of Strongly Agree (5), Agree (4), Neutral (3), Disagree (2), and Strongly Disagree (1).

Questions 37 through 40 ask the frequency of assessment plan revisions based on the accreditation agency, the institution, experiences, and results. To analyze the frequency of revisions, a MANOVA was used. The responses for these four questions were the dependent variable in the MANOVA. 
Questions 85 through 92 are explained under Research Question 2. These same questions were examined for differences by accreditation body. These questions, which look at assessment success indicators, were analyzed using a MANOVA. The responses for questions 85 through 92 were the dependent variable in the MANOVA.

\section{Limitations}

This study was limited by the type of analysis. Although planned comparisons are more powerful, they have a higher likelihood of a Type I error than post-hoc comparisons (Lomax, 2001). For example, the research could have shown that there was a difference in assessment practices by accreditation body when in fact, the response rate of a representative agency did not allow for a normal distribution. The use of MANOVAs protects against experiment-wise error rate and helps reduce Type I errors. Taking a census of the population minimized this risk; however, not all surveys were returned. In addition, the study used a population and for Research Question 3, the groups (by accreditation body) were not be similar in size. "Such unequal sample sizes across groups can reduce the power of a MANOVA" (Harlow, 2005, p. 116). Limitations also included the increasing work load of higher education employees and the lack of time to complete surveys, the potential to answer survey questions with best guesses rather than actual data, and the possibility that a single person on campus may not have had all the facts to answer a complete survey. A final limitation was the potential inflation of data provided in an unconscious tendency to reflect well on the unit described by the participant.

\section{Background of Researcher}

The researcher has worked at two higher education institutions. She served for ten years as assistant professor and coordinator of the Information Systems Department, under the School of Business, at Fairmont State University. Fairmont State is a public university and has an 
enrollment of approximately 7,750 students. She currently holds an assistant professor position in the Business and Economics Department at West Virginia Wesleyan College. West Virginia Wesleyan College is a private liberal arts college with an enrollment of just over 1,200 students. She has a successful grant record and has received funding from NASA, NSF, the Corporation for National Service, and her employing institutions. She has presented at national and international conferences and has also successfully published peer-reviewed higher education topics as well as an invited case for a book. Her previously earned degrees include a Bachelor of Science in Industrial Engineering from Wheeling Jesuit University and a Master of Science in Industrial and Labor Relations from West Virginia University.

\section{Summary}

This chapter discussed the methodology to be used to determine the answers to the research questions. The research design was presented, and the population was described. The analytical techniques for each of the research questions and the nine AAHE principles were reviewed. This section concluded with a summary of the limitations of the study. 


\section{CHAPTER 4: RESULTS}

\section{Overview}

This chapter provides the details of the research results. First, the basic survey data response is reviewed, and then demographic analysis is provided to show the participants of the study. The completed data analysis is then presented by research question. The first research question queried the degree accredited business schools followed the best practices in assessment. The second research question looked for correlations in assessment activities with the success of business schools. The third research question examined significant differences in outcomes assessment practices by IACBE, ACBSP, and AACSB accreditations. Finally, a summary concludes this chapter.

\section{Survey Response}

The researcher sent 935 surveys to the assessment or accreditation coordinator at business schools in the United States. Surveys were sent to all institutions on mailing lists obtained from AACSB, ACBSP, and IACBE. Two surveys of the 935 mailed were returned by the post office with a forwarding service expiration notification, so the total of potential surveys received by participants was 933. An inspection of the list from AACSB yielded potential institutions with graduate only accreditation. There were 25 such institutions and these were removed leaving 908 potential survey participants. No modifications were made to the mailing lists; however, an analysis of the combined lists produced nineteen institutions that were potentially on more than one list. It was determined that thirteen institutions actually held dual accreditation with two of the business accreditation agencies in the study which left 895 potential participating business units. The remaining six were either similarly named institutions, distinct campuses of an institution with different administration, or different degree programs. Only three of the thirteen 
double listed surveys were returned and only one returned completed versions of the surveys that were mailed (the other institutions sent a blank copy back and/or indicated that they received a duplicate mailing). The return rate of surveys by the due date of April 27, 2007 was 121/895 but taking into account the duplicates, the actual individual institutions return rate was 120/895 or 13.4\%. One institution accidentally sent a student reference in the survey envelope and, after contact, arrangements were made to forward the student reference and a new survey was mailed to that institution. A number of institutions made personal contact and indicated that they would be mailing the survey later than the 27th due to extenuating circumstances. The total number of institutions responding to the survey request was 217 which included 88 of the surveys sent from the list provided by AACSB, 79 surveys based on the ACBSP list, and 50 IACBE responding institutions. The total surveys returned, after the initial mailing and the postcard reminder, based on the actual mailings sent and received, was 217 out of a possible 935 or $23.2 \%$.

After a review of the responses, there were a few surveys that indicated the institution's business unit was not accredited, additional information provided from some of those responses indicated that they were seeking accreditation but had not completed the process. Their candidacy status was the reason they were included in the initial group. Those surveys were removed from the data analysis. In addition, a small number of surveys were removed because an institution indicated that they were accredited at the graduate level only and/or only had a graduate degree in the business unit. After removing those surveys, the final total of returned and usable surveys was 203. Using the adjusting mailing and return values, the corrected return rate was $22.7 \%$ (203/895). The corrected response rates by associated accreditation body (see Table 8) indicate that although AACSB had the largest number of usable surveys returned (83), ACBSP had the largest return percent $(26.06 \%)$. ACBSP is also the only accreditation agency in 
the study that accredits Associate's level programs and there were 27 responding units that offered only Associate business degrees. Although these degrees are considered to be undergraduate-level, there are significant differences in mission and courses offered at the associate-level compared to baccalaureate-level degrees. For this reason, they were not included in the analysis and results.

Table 8

All Survey Respondents by Accreditation Group

\begin{tabular}{lccc}
\hline Accreditation Group & Corrected Returned & Corrected Mailed & Return Rate \\
\hline AACSB & 83 & 436 & $19.04 \%$ \\
ACBSP & 74 & 284 & \\
ACBSP & 47 & & \\
$\quad$ Associate Only & 27 & & \\
IACBE & 37 & $188.06 \%$ \\
Multiple Groups & $9^{\mathrm{a}}$ & $13^{\mathrm{b}}$ & $19.68 \%$ \\
Total & 203 & 895 & $\mathrm{n} / \mathrm{a}$ \\
\hline
\end{tabular}

${ }^{a}$ The multiple group category value for Corrected Return refers to the number of institutions who self-reported multiple specialized accreditation (including accreditation other than Businessrelated). ${ }^{b}$ The Corrected Mailed value refers to the number of institutions that were listed in two accreditation groups based on the business mailing lists used for this survey. This number is reduced from the total as only one per institution was counted in the study.

The total of surveys included in this research was 167 and included 83 AACSB units, 47 ACBSP units, and 37 IACBE units (see Table 9). 
Table 9

Business Units Included in Study by Accreditation Group

\begin{tabular}{lcc}
\hline Accreditation Group & $\mathrm{N}$ & $\%$ \\
\hline AACSB & 83 & 49.70 \\
ACBSP & 47 & 28.14 \\
IACBE & 37 & 22.16 \\
Total & 167 & 100.00 \\
\hline
\end{tabular}

Demographic Analysis

Institution

The average age of the institutions responding to the survey was approximately 108 years old $(\mathrm{N}=157)$. The oldest reported institution participating in the survey was founded in 1693 and the newest 300 years later, in 1993 (see Table 10). There was a nearly equal representation of public (49.65\%) and private institutions (50.35\%) responding in the study (see Table 11 ).

Table 10

Frequency of Institution Year Founded by Accreditation

\begin{tabular}{lrrrrrrrr}
\hline & \multicolumn{2}{c}{$A A C S B$} & \multicolumn{2}{c}{ ACBSP } & \multicolumn{2}{c}{ IACBE } & \multicolumn{2}{c}{ All Accreditations } \\
& $N$ & \multicolumn{1}{c}{$\%$} & \multicolumn{1}{c}{$N$} & \multicolumn{1}{c}{$\%$} & \multicolumn{1}{c}{$N$} & $\%$ & $N$ & $\%$ \\
\hline $1693-1799$ & 2 & 2.63 & 0 & 0.00 & 1 & 2.78 & 3 & 1.91 \\
$1800-1849$ & 5 & 6.58 & 8 & 17.78 & 4 & 11.11 & 17 & 10.83 \\
$1850-1899$ & 37 & 48.68 & 15 & 33.33 & 10 & 27.78 & 62 & 39.49 \\
$1900-1949$ & 19 & 25.00 & 11 & 24.44 & 16 & 44.44 & 46 & 29.30 \\
$1950-1999$ & 13 & 17.11 & 11 & 24.44 & 5 & 13.89 & 29 & 18.47 \\
Total & 76 & 100.00 & 45 & $100.00 *$ & 36 & 100.00 & 157 & 100.00 \\
\hline
\end{tabular}

*Rounding Error 
Table 11

Survey Participants by Institution Control

\begin{tabular}{lcccccccc}
\hline & \multicolumn{2}{c}{$A A C S B$} & & ACBSP & \multicolumn{2}{c}{ IACBE } & \multicolumn{2}{c}{ Total } \\
\hline & $N$ & $\%$ & $N$ & $\%$ & $N$ & $\%$ & $N$ & $\%$ \\
Private & 19 & 27.14 & 23 & 58.97 & 29 & 90.63 & 71 & 50.35 \\
Public & 51 & 72.86 & 16 & 41.03 & 3 & 9.38 & 70 & 49.65 \\
Total & 70 & 100.00 & 39 & 100.00 & 32 & $100.00 *$ & 141 & 100.00 \\
\hline Note. Rounding Error & & & & & & &
\end{tabular}

The majority of the respondents $(80.24 \%)$ reported that their institution focus was teaching (see Table 12). The fact that such a large group of the survey selected teaching as their focus indicated that they had student learning as a primary institutional goal. The remaining institutions reported nearly equal values of research (8.98\%) and other (8.38\%). No institutions selected service as their focus. Detailed information indicated that the focus of the institutions who selected other, rather than one of the three main focus areas (teaching, research, and service), was generally a combination of two (teaching and research) or three (teaching, research, and service) of those categories. One institution indicated that their focus was military. 
Table 12

Participant Institution Focus

\begin{tabular}{lcccccccc}
\hline & & AACSB & & \multicolumn{2}{c}{ ACBSP } & \multicolumn{2}{c}{ IACBE } & \multicolumn{2}{c}{ Total } \\
\hline & $N$ & $\%$ & $N$ & $\%$ & $N$ & $\%$ & $N$ & $\%$ \\
\hline Other & 12 & 14.46 & 2 & 4.26 & 0 & 0.00 & 14 & 8.38 \\
Research & 13 & 15.66 & 1 & 2.13 & 1 & 2.70 & 15 & 8.98 \\
Teaching & 54 & 65.06 & 44 & 93.62 & 36 & 97.30 & 134 & 80.24 \\
Total & 83 & $100.00 *$ & 47 & $100.00 *$ & 37 & 100.00 & 167 & 100.00 \\
\hline \multicolumn{2}{l}{ Note. Rounding Error } & & & & & & &
\end{tabular}

The mean number of students at the reported institutions was 8,015.23 $(N=157, S D=$ 8,519.68). The smallest number of students at an institution was 520 and the largest student population was reported as 50,000 (see Table 13). The AACSB institution student enrollments were distributed relatively evenly; however, the ACBSP and IACBE student enrollments were weighted toward lower student populations. In fact, $88.57 \%$ of IACBE institutions and $60.87 \%$ of ACBSP institutions were under 5,000 students. 
Table 13

Number of Students in Participating Institutions

\begin{tabular}{|c|c|c|c|c|c|c|c|c|}
\hline & \multicolumn{2}{|c|}{$A A C S B$} & \multicolumn{2}{|c|}{$A C B S P$} & \multicolumn{2}{|c|}{$I A C B E$} & \multicolumn{2}{|c|}{ Total } \\
\hline & $N$ & $\%$ & $N$ & $\%$ & $N$ & $\%$ & $N$ & $\%$ \\
\hline 0-999 & 0 & 0.00 & 0 & 0.00 & 4 & 11.43 & 4 & 2.55 \\
\hline 1000-1999 & 4 & 5.26 & 11 & 23.91 & 13 & 37.14 & 28 & 17.83 \\
\hline 2000-2999 & 1 & 1.32 & 10 & 21.74 & 11 & 31.43 & 22 & 14.01 \\
\hline 3000-3999 & 6 & 7.89 & 7 & 15.22 & 2 & 5.71 & 15 & 9.55 \\
\hline $4000-4999$ & 5 & 6.58 & 0 & 0.00 & 1 & 2.86 & 6 & 3.82 \\
\hline $5000-5999$ & 2 & 2.63 & 4 & 8.70 & 0 & 0.00 & 6 & 3.82 \\
\hline $6000-6999$ & 9 & 11.84 & 5 & 10.87 & 2 & 5.71 & 16 & 10.19 \\
\hline 7000-7999 & 3 & 3.95 & 3 & 6.52 & 0 & 0.00 & 6 & 3.82 \\
\hline 8000-8999 & 6 & 7.89 & 1 & 2.17 & 0 & 0.00 & 7 & 4.46 \\
\hline $9000-9999$ & 2 & 2.63 & 3 & 6.52 & 0 & 0.00 & 5 & 3.18 \\
\hline 10000-10999 & 4 & 5.26 & 0 & 0.00 & 1 & 2.86 & 5 & 3.18 \\
\hline 11000-11999 & 6 & 7.89 & 0 & 0.00 & 0 & 0.00 & 6 & 3.82 \\
\hline 12000-12999 & 2 & 2.63 & 0 & 0.00 & 0 & 0.00 & 2 & 1.27 \\
\hline 13000-13999 & 5 & 6.58 & 0 & 0.00 & 0 & 0.00 & 5 & 3.18 \\
\hline 14000-14999 & 1 & 1.32 & 0 & 0.00 & 0 & 0.00 & 1 & 0.64 \\
\hline $15000-15999$ & 0 & 0.00 & 0 & 0.00 & 0 & 0.00 & 0 & 0.00 \\
\hline $16000-16999$ & 0 & 0.00 & 0 & 0.00 & 0 & 0.00 & 0 & 0.00 \\
\hline 17000-17999 & 3 & 3.95 & 0 & 0.00 & 0 & 0.00 & 3 & 1.91 \\
\hline 18000-18999 & 1 & 1.32 & 1 & 2.17 & 0 & 0.00 & 2 & 1.27 \\
\hline 19000-19999 & 0 & 0.00 & 1 & 2.17 & 0 & 0.00 & 1 & 0.64 \\
\hline 20000-20999 & 2 & 2.63 & 0 & 0.00 & 0 & 0.00 & 2 & 1.27 \\
\hline 21000-21999 & 0 & 0.00 & 0 & 0.00 & 0 & 0.00 & 0 & 0.00 \\
\hline 22000-22999 & 1 & 1.32 & 0 & 0.00 & 0 & 0.00 & 1 & 0.64 \\
\hline 23000-23999 & 2 & 2.63 & 0 & 0.00 & 0 & 0.00 & 2 & 1.27 \\
\hline $24000-24999$ & 2 & 2.63 & 0 & 0.00 & 0 & 0.00 & 2 & 1.27 \\
\hline $25000-25999$ & 1 & 1.32 & 0 & 0.00 & 0 & 0.00 & 1 & 0.64 \\
\hline 26000-26999 & 1 & 1.32 & 0 & 0.00 & 1 & 2.86 & 2 & 1.27 \\
\hline 27000-27999 & 0 & 0.00 & 0 & 0.00 & 0 & 0.00 & 0 & 0.00 \\
\hline 28000-28999 & 2 & 2.63 & 0 & 0.00 & 0 & 0.00 & 2 & 1.27 \\
\hline 29000-29999 & 0 & 0.00 & 0 & 0.00 & 0 & 0.00 & 0 & 0.00 \\
\hline $30000-30999$ & 3 & 3.95 & 0 & 0.00 & 0 & 0.00 & 3 & 1.91 \\
\hline 40000 & 1 & 1.32 & 0 & 0.00 & 0 & 0.00 & 1 & 0.64 \\
\hline 50000 & 1 & 1.32 & 0 & 0.00 & 0 & 0.00 & 1 & 0.64 \\
\hline Total & 76 & 100.00 & 46 & 100.00 & 35 & 100.00 & 157 & 100.00 \\
\hline
\end{tabular}


Approximately one-third (35.98\%) of the institutions were regionally accredited by Southern Association of Colleges and another one-third (32.5\%) were accredited by North Central Association of Colleges and Schools Higher Learning Commission. Middle States Association of Colleges and Schools regionally accredited $17.2 \%$, and the remaining regional accreditation agencies each comprised less than 5\% (see Table 14 and Figure 4).

Table 14

Regional Accreditation Agency of Respondents

\begin{tabular}{lcccccccc}
\hline & \multicolumn{2}{c}{$A A C S B$} & \multicolumn{2}{c}{ ACBSP } & \multicolumn{2}{c}{ IACBE } & \multicolumn{2}{c}{ Total } \\
& $N$ & $\%$ & $N$ & $\%$ & $N$ & $\%$ & $N$ & $\%$ \\
\hline MSA & 11 & 13.58 & 11 & 23.91 & 6 & 16.22 & 28 & 17.07 \\
NCA-HLC & 24 & 29.63 & 11 & 23.91 & 18 & 48.65 & 53 & 32.32 \\
NEASC-CIHE & 5 & 6.17 & 0 & 0.00 & 1 & 2.70 & 6 & 3.66 \\
NWCCU & 4 & 4.94 & 2 & 4.35 & 4 & 10.81 & 10 & 6.10 \\
SACS & 31 & 38.27 & 21 & 45.65 & 7 & 18.92 & 59 & 35.98 \\
WASC-ACSCU & 6 & 7.41 & 1 & 2.17 & 1 & 2.70 & 8 & 4.88 \\
Total & 81 & 100.00 & 46 & 100.00 & 37 & 100.00 & 164 & 100.00 \\
\hline
\end{tabular}




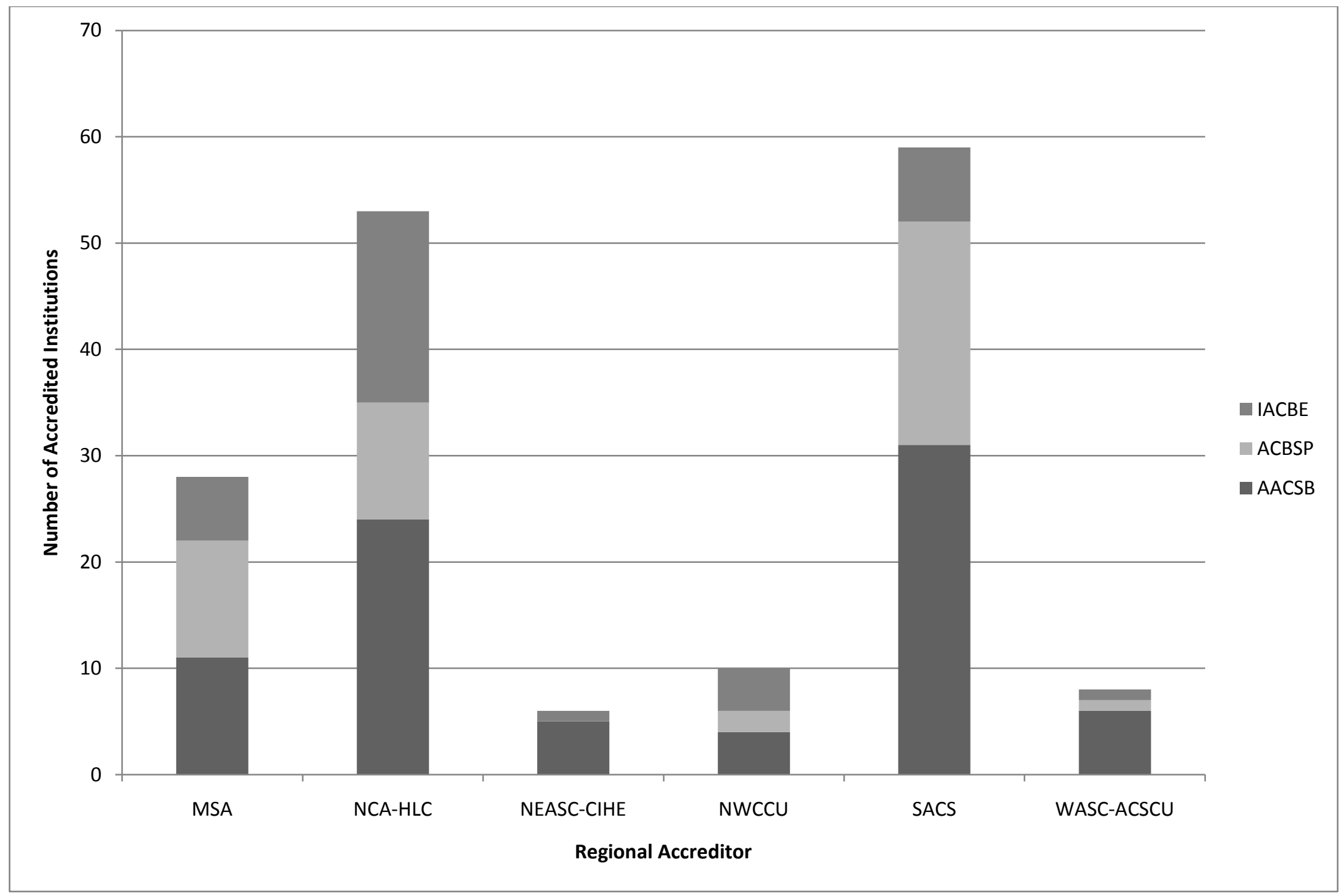

Figure 4. Regional Accreditation of Respondents Indicating Specialized Accreditation 
The final institution-level demographic collected was the review date for regional accreditation. Although less than half (74/167) of the surveys indicated the date, all of those responding indicated a review date after 1997 (see Table 15). Five of the responding institutions indicated a future review date with the furthest date projection of 2019. Exactly half reported review dates of 2003 and before. Nearly one fourth $(24.3 \%)$ of the reported review dates were in the year of the study and the year prior.

Table 15

Regional Institutional Accreditation Review Date

\begin{tabular}{|c|c|c|}
\hline Year Reviewed & $N$ & $\%$ \\
\hline 1997 & 2 & 2.7 \\
\hline 1998 & 8 & 10.8 \\
\hline 1999 & 3 & 4.1 \\
\hline 2000 & 8 & 10.8 \\
\hline 2001 & 7 & 9.5 \\
\hline 2002 & 7 & 9.5 \\
\hline 2003 & 2 & 2.7 \\
\hline 2004 & 7 & 9.5 \\
\hline 2005 & 7 & 9.5 \\
\hline 2006 & 10 & 13.5 \\
\hline 2007 & 8 & 10.8 \\
\hline 2008 & 2 & 2.7 \\
\hline 2009 & 2 & 2.7 \\
\hline 2019 & 1 & 1.4 \\
\hline Total & 74 & 100 \\
\hline
\end{tabular}




\section{Business Units}

The majority of the business units responding were Schools of Business (39.35\%), followed by Colleges of Businesses (35.77\%), and then Departments of Business (16.77\%). Of the business units that reported a different classification $(7.10 \%)$, there were a few that had Division in their title, either Division of Business or Division of Business Studies (see Table 16). There were also singular mentions of specific department concentrations (i.e. Accounting, Management, Business Technologies, and Economics). The common name for many units has been Schools of Business. As institutions begin to expand into graduate offerings, many have changed their status to University and have renamed their units College of Business. It is important to note that accreditation bodies look at the administration structure to ensure that the Business unit has immediate reporting to the Chief Academic Officer of the institution without any intermediate offices and also that the Business Unit does not share resources with other units, thus limiting the power to use resources to achieve goals.

Table 16

Business Unit Name Frequency

\begin{tabular}{lcccccccc}
\hline & \multicolumn{2}{c}{$A A C S B$} & \multicolumn{2}{c}{$A C B S P$} & \multicolumn{2}{c}{ IACBE } & \multicolumn{2}{c}{ Total } \\
& $N$ & $\%$ & $N$ & $\%$ & $N$ & $\%$ & $N$ & $\%$ \\
\hline $\begin{array}{l}\text { College of } \\
\text { Business }\end{array}$ & 42 & 53.85 & 10 & 22.73 & 5 & 15.15 & 57 & 36.77 \\
$\begin{array}{l}\text { Department of } \\
\text { Business }\end{array}$ & 1 & 1.28 & 13 & 29.55 & 12 & 36.36 & 26 & 16.77 \\
$\begin{array}{l}\text { School of Business } \\
\text { Other }\end{array}$ & 33 & 42.31 & 16 & 36.36 & 12 & 36.36 & 61 & 39.35 \\
Total & 2 & 2.56 & 5 & 11.36 & 4 & 12.12 & 11 & 7.10 \\
\hline Note. Rounding Error & 78 & 100.00 & 44 & 100.00 & 33 & 100.00 & 155 & $100.00^{*}$ \\
\hline
\end{tabular}




\section{Specialized Accreditation}

The largest specialized accreditation body, AACSB, accredited 87 of the 167 units. There were two institutions responding that had held AACSB accreditation since 1926. Over half of the responding institutions received their accreditation since 1990 (see Table 17) and all of the units had their last review since that date (see Table 18).

Table 17

Year Awarded AACSB Accreditation

\begin{tabular}{ccc}
\hline Year & $N$ & $\%$ \\
\hline $1926-1929$ & 2 & 2.90 \\
$1930-1939$ & 1 & 1.45 \\
$1940-1949$ & 0 & 0.00 \\
$1950-1959$ & 5 & 7.25 \\
$1960-1969$ & 6 & 8.70 \\
$1970-1979$ & 12 & 17.39 \\
$1980-1989$ & 7 & 10.14 \\
$1990-1999$ & 15 & 21.74 \\
$2000-2007$ & 21 & 30.43 \\
Total & 69 & 100.00 \\
\hline
\end{tabular}

Table 18

AACSB Review Date

\begin{tabular}{ccc}
\hline Year & $N$ & $\%$ \\
\hline $1990-1994$ & 1 & 1.49 \\
$1995-1999$ & 14 & 20.90 \\
$2000-2004$ & 26 & 38.81 \\
$2005-2009$ & 26 & 38.81 \\
Total & 67 & $100.01^{*}$ \\
\hline
\end{tabular}

Note. Rounding Error 
The next specialized accreditation body, ACBSP, accredited 43 of the bachelor-degree granting units and 38 associate-degree granting units, which were not included in the study. The earliest of the 43 bachelor-level ACBSP accreditations was awarded in 1987 (see Table 19).

Interestingly, the average date the accreditation was awarded and the average date of the last review were less than six years apart (see Table 20).

Table 19

Year Awarded ACBSP Accreditation

\begin{tabular}{ccc}
\hline Year & $N$ & $\%$ \\
\hline $1987-1989$ & 2 & 4.65 \\
$1990-1999$ & 30 & 69.77 \\
$2000-2008$ & 11 & 25.58 \\
Total & 43 & 100.00 \\
\hline
\end{tabular}

Table 20

ACBSP Review Date

\begin{tabular}{ccc}
\hline Year & $N$ & $\%$ \\
\hline $1987-1989$ & 2 & 5.56 \\
$1990-1994$ & 2 & 5.56 \\
$1995-1999$ & 2 & 5.56 \\
$2000-2004$ & 13 & 36.11 \\
$2005-2007$ & 17 & 47.22 \\
Total & 36 & 100.00 \\
\hline
\end{tabular}


The final specialized business accreditation body, IACBE, accredited 41 units. As shown in Table 21, IACBE is the agency with the most recent accreditation roots. The earliest IACBE accreditation occurred in 1997, ten years after the earliest ACBSP accreditation and 71 years after AACSB awarded their first specialized accreditation (see Table 21). Similar to ACBSP, the average date the accreditation was awarded and the average date of the last review are close together, less than two years apart (see Table 22).

Table 21

Year Awarded IACBE Accreditation

\begin{tabular}{ccc}
\hline Year & $N$ & $\%$ \\
\hline $1997-1999$ & 4 & 12.12 \\
$2000-2008$ & 29 & 87.88 \\
Total & 33 & 100.00 \\
\hline
\end{tabular}

Table 22

IACBE Review Date

\begin{tabular}{ccc}
\hline Year & $N$ & $\%$ \\
\hline $2000-2004$ & 5 & 17.24 \\
$2005-2007$ & 24 & 82.76 \\
Total & 29 & 100.0 \\
\hline
\end{tabular}

There were four other specialized accreditations reported by the respondents. They included the American Bar Association (ABA), which accredits legal programs; ABET, Inc., which accredits Engineering and Computing Programs; the European Quality Improvement System (EQUIS), which is an international accreditation agency for management and business 
administration; and the National Association of Industrial Technology (NAIT), which accredits technical or technical management programs. Only one instance of each accreditation was reported.

Faculty and Students

The average number of full-time faculty reported in the academic units ranged from 2 to 151 (see Table 23) with a mean of $34.04(N=164, S D=31.06)$. There were a reported 0 to 1,500 part-time faculty in the units (see Table 24$)$ with a mean of $27.60(N=156, S D=122.05)$. The range of students was great with a minimum of 35 to a maximum unit enrollment of 9,015 (see Table 25). The mean enrollment was $1,361.98(N=160, S D=1,482.73)$. 
Table 23

Number of Full-Time Faculty Members in Business Units

\begin{tabular}{|c|c|c|}
\hline Number of Faculty & $\mathrm{N}$ & $\%$ \\
\hline$<10$ & 31 & 18.90 \\
\hline $10-19$ & 40 & 24.39 \\
\hline $20-29$ & 25 & 15.24 \\
\hline $30-39$ & 16 & 9.76 \\
\hline $40-49$ & 12 & 7.32 \\
\hline $50-59$ & 13 & 7.93 \\
\hline $60-69$ & 9 & 5.49 \\
\hline $70-79$ & 3 & 1.83 \\
\hline $80-89$ & 2 & 1.22 \\
\hline $90-99$ & 2 & 1.22 \\
\hline $100-109$ & 4 & 2.44 \\
\hline $110-119$ & 1 & 0.61 \\
\hline $120-129$ & 3 & 1.83 \\
\hline $130-139$ & 2 & 1.22 \\
\hline $140-149$ & 0 & 0.00 \\
\hline$>150$ & 1 & 0.61 \\
\hline Total & 164 & 100.00 \\
\hline
\end{tabular}


Table 24

Number of Part Time Faculty Members in Business Units

\begin{tabular}{|c|c|c|}
\hline Number of Faculty & $\mathrm{N}$ & $\%$ \\
\hline$<10$ & 76 & 48.72 \\
\hline $10-19$ & 38 & 24.36 \\
\hline $20-29$ & 19 & 12.18 \\
\hline $30-39$ & 14 & 8.97 \\
\hline $40-49$ & 2 & 1.28 \\
\hline $50-59$ & 1 & 0.64 \\
\hline $60-69$ & 2 & 1.28 \\
\hline $90-99$ & 1 & 0.64 \\
\hline $100-109$ & 1 & 0.64 \\
\hline $110-119$ & 1 & 0.64 \\
\hline $120-129$ & 0 & 0.00 \\
\hline $130-139$ & 1 & 0.64 \\
\hline Total & 156 & 100.00 \\
\hline
\end{tabular}


Table 25

Number of Students in Business Units

\begin{tabular}{ccc}
\hline $\begin{array}{c}\text { Number } \\
\text { Students }\end{array}$ & $\mathrm{N}$ & $\%$ \\
\hline $0-499$ & 57 & 79.17 \\
$500-999$ & 31 & 43.06 \\
$1000-1499$ & 21 & 29.17 \\
$1500-1999$ & 14 & 19.44 \\
$2000-2499$ & 15 & 20.83 \\
$2500-2999$ & 1 & 1.39 \\
$3000-3499$ & 7 & 9.72 \\
$3500-3999$ & 5 & 6.94 \\
$4000-4499$ & 0 & 0.00 \\
$4500-4999$ & 2 & 2.78 \\
$>5000$ & 72 & 9.72 \\
Total & 700 \\
\hline
\end{tabular}

The average annual graduates in the business unit varied from 0 to 1,250 for Associate's degrees, 0 to 1,600 for Bachelor's degrees, 0 to 1,000 for Master's degrees, and 0 to 30 for Doctorate's (see Table 26). Although the focus of this study was Bachelor-level programs, all data for graduates at each level was collected. The mean size of the responding annual Bachelorlevel graduations per academic year was $255.52(N=145, S D=309.77)$. 
Table 26

Number of Business Graduates by Level

\begin{tabular}{ccccc}
\hline Graduates & Associate & Bachelor & Masters & Doctorate \\
\hline $1-24$ & 15 & 6 & 34 & 11 \\
$25-49$ & 2 & 15 & 15 & 1 \\
$50-99$ & 3 & 27 & 20 & 0 \\
$100-199$ & 0 & 39 & 20 & 0 \\
$200-499$ & 1 & 36 & 8 & 0 \\
$500-999$ & 1 & 13 & 2 & 0 \\
$>1000$ & 1 & 8 & 1 & 0 \\
\hline
\end{tabular}

The most common degrees offered at the Associate, Bachelor, and Master levels were General Business followed closely by Accounting (see Table 27). The most common Doctoratelevel degree was Management. There were 10 institutions that offered Doctorate's in Management, 9 that offered degrees in Accounting and 9 that offered Finance Doctorate's (see Table 27).

In addition to those subjects listed in the table, a few institutions indicated that they offered degrees in Entrepreneurship, International Business, International Business, Entrepreneurship, Sport Management, Tax, Business Administration, Horsemanship/Equine Studies, Project Management, Tourism Administration, Small Business and Entrepreneurship, and Supply Chain. Three institutions indicated that they offered degrees in International Business and none of the other subject areas were indicated by more than one institution. 
Table 27

Number of Responding Units Offering Degrees by Subject and Level

\begin{tabular}{|c|c|c|c|c|c|c|c|c|}
\hline \multirow[b]{2}{*}{ Subject Area } & \multicolumn{2}{|c|}{ Associate } & \multicolumn{2}{|c|}{ Bachelor } & \multicolumn{2}{|c|}{ Master } & \multicolumn{2}{|c|}{ Doctorate } \\
\hline & $N$ & $\%$ & $N$ & $\%$ & $N$ & $\%$ & $N$ & $\%$ \\
\hline Accounting & 13 & 7.78 & 120 & 71.86 & 54 & 32.34 & 9 & 5.39 \\
\hline Business Education & 3 & 1.80 & 26 & 15.57 & 7 & 4.19 & 0 & 0.00 \\
\hline $\begin{array}{l}\text { Computer/Information } \\
\text { Systems }\end{array}$ & 12 & 7.19 & 90 & 53.89 & 26 & 15.57 & 7 & 4.19 \\
\hline Economics & 3 & 1.80 & 59 & 35.33 & 20 & 11.98 & 9 & 5.39 \\
\hline Finance & 6 & 3.59 & 80 & 47.90 & 24 & 14.37 & 9 & 5.39 \\
\hline General Business & 17 & 10.18 & 126 & 75.45 & 86 & 51.50 & 5 & 2.99 \\
\hline Management & 9 & 5.39 & 89 & 53.29 & 30 & 17.96 & 10 & 5.99 \\
\hline Marketing & 7 & 4.19 & 89 & 53.29 & 16 & 9.58 & 7 & 4.19 \\
\hline Other & 12 & 7.19 & 49 & 29.34 & 20 & 11.98 & 2 & 1.20 \\
\hline
\end{tabular}

Note. Total $\mathrm{N}=167$ Responding Units

A common practice of business units is to offer a degree in Business Administration but offer students an opportunity to focus in one area of business. This is slightly different than having separate degrees, as all of the Business Administration students take a common core group of courses and then take a small number of specialization courses (although some institutions do have a common core across degrees). Accounting, Finance, Management, and Marketing were each offered as specializations in over half of the responding units. Over one fourth of the responding units offered specializations in Business administration, MIS, Human Resource Management, and International Business (see Table 28). In addition to these focus areas, Sport Management was mentioned as a potential focus area by five institutions, 
Technology Management at two institutions, and single mentions were made of many other interesting subject areas including Agribusiness, Aviation management, Environmental Management, Project Management, Health Information Management, and others.

Table 28

General Business Degree Specialization Areas

\begin{tabular}{|c|c|c|}
\hline Specialization Area & $N$ & $\%$ \\
\hline Accounting & 131 & 78.44 \\
\hline Business Administration & 89 & 53.29 \\
\hline MIS & 92 & 55.09 \\
\hline E Business/E-Commerce & 6 & 3.59 \\
\hline Economics & 58 & 34.73 \\
\hline Entrepreneurship & 39 & 23.35 \\
\hline Finance & 113 & 67.66 \\
\hline Tourism & 13 & 7.78 \\
\hline Human Resource Management & 47 & 28.14 \\
\hline Insurance & 7 & 4.19 \\
\hline International & 54 & 32.34 \\
\hline Management & 119 & 71.26 \\
\hline Marketing & 130 & 77.84 \\
\hline Production & 5 & 2.99 \\
\hline Real Estate & 16 & 9.58 \\
\hline Logistics & 17 & 10.18 \\
\hline Other & 34 & 20.36 \\
\hline
\end{tabular}

Note. Total $\mathrm{N}=167$ Responding Units 
Frequencies were determined by accreditation body for survey question 28 to show the level of assessment efforts in the unit and the breakdown of assessment activity by accreditation group (see Table 29). As shown in the table, only one institution did not have an assessment plan nor an intention to create one. The ACBSP units indicated the most maturity in their assessment efforts as $40.4 \%$ of them indicated that they review their assessment plan and have been making changes consistently over time. Over two-thirds $(68.1 \%)$ of the units reported that they had been reviewing assessment results and were either beginning to plan actions based on those results or had already been making changes based on the results of assessment. 
Table 29

Assessment Plan Efforts to Date

\begin{tabular}{|c|c|c|c|c|c|c|c|c|}
\hline & \multicolumn{2}{|c|}{ All } & \multicolumn{2}{|c|}{$A A C S B$} & \multicolumn{2}{|c|}{$A C B S P$} & \multicolumn{2}{|c|}{$I A C B E$} \\
\hline & $N$ & $\%$ & $N$ & $\%$ & $N$ & $\%$ & $N$ & $\%$ \\
\hline No Response & 8 & 4.79 & 4 & 4.8 & 2 & 4.3 & 2 & 5.4 \\
\hline No plan; not planning to create one & 1 & 0.60 & 0 & 0.0 & 0 & 0.0 & 1 & 2.7 \\
\hline No plan; beginning to develop one & 3 & 1.80 & 0 & 0.0 & 3 & 6.4 & 0 & 0.0 \\
\hline Planned but not implemented & 2 & 1.20 & 2 & 2.4 & 0 & 0.0 & 0 & 0.0 \\
\hline $\begin{array}{l}\text { Early implementation stage; no assessment } \\
\text { results }\end{array}$ & 12 & 7.19 & 5 & 6.0 & 3 & 6.4 & 4 & 10.8 \\
\hline Beginning to review early assessment results & 26 & 15.57 & 17 & 20.5 & 6 & 12.8 & 3 & 8.1 \\
\hline $\begin{array}{l}\text { Reviewing results and beginning to formulate } \\
\text { action plan }\end{array}$ & 27 & 16.17 & 18 & 21.7 & 6 & 12.8 & 3 & 8.1 \\
\hline $\begin{array}{l}\text { Implementing actions based on assessment } \\
\text { results }\end{array}$ & 39 & 23.35 & 20 & 24.1 & 8 & 17.0 & 11 & 29.7 \\
\hline $\begin{array}{l}\text { Assessment plan is reviewed; changes have } \\
\text { been made consistently to the plan over time }\end{array}$ & 49 & 29.34 & 17 & 20.5 & 19 & 40.4 & 13 & 35.1 \\
\hline Total & 167 & 100.00 & 83 & 100.0 & 47 & 100.0 & 37 & 100.0 \\
\hline
\end{tabular}


Survey questions 29 through 32 examined who developed and had responsibility for the assessment plan. The units reported the highest level of activity in joint faculty and administration committees (see Table 30). These committees generally developed, (43.8\%), updated (36.0\%), and monitored (39.4\%) the unit assessment plans. The only action that was not the largest primary responsibility of these joint committees was reporting assessment results. Administrators (40.4\%) tended to report on the results of the assessment efforts in business units. Administrative committees were not reported as an active force in any assessment efforts in business units, participating less than $4 \%$ in all categories. Not surprisingly, individual faculty were more active in IACBE accredited units (which are generally smaller). Administrators and committees were more active on ACBSP and AACSB campuses compared to IACBE.

Table 30

Accreditation Plan Efforts by Accreditation Agency

\begin{tabular}{ccccccccc}
\hline & & Developed Plan & Updates Plan & Monitors Plan & Reports Results \\
\cline { 2 - 8 } Constituent Total & & & & & & & & \\
Agency & $N$ & $\%$ & $N$ & $\%$ & $N$ & $\%$ & $N$ & $\%$ \\
\hline Faculty Member & 25 & 14.97 & 26 & 15.57 & 19 & 11.38 & 25 & 14.97 \\
AACSB & 8 & 9.64 & 5 & 6.02 & 3 & 3.61 & 5 & 6.02 \\
ACBSP & 7 & 14.89 & 8 & 17.02 & 7 & 14.89 & 7 & 14.89 \\
IACBE & 10 & 27.03 & 13 & 35.14 & 9 & 24.32 & 11 & 29.73 \\
Faculty Committee & 64 & 38.32 & 49 & 29.34 & 41 & 24.55 & 40 & 23.95 \\
AACSB & 36 & 43.37 & 27 & 32.53 & 24 & 28.92 & 25 & 30.12 \\
ACBSP & 16 & 34.04 & 13 & 27.66 & 10 & 21.28 & 8 & 17.02 \\
IACBE & 12 & 32.43 & 9 & 24.30 & 7 & 18.92 & 7 & 18.92 \\
\hline
\end{tabular}


Table 30 Continued

Accreditation Plan Efforts by Accreditation Agency

\section{Developed Plan Updates Plan Monitors Plan Reports Results}

\section{Constituent Total}

\begin{tabular}{ccccccccc} 
Agency & $N$ & $\%$ & $N$ & $\%$ & $N$ & $\%$ & $N$ & $\%$ \\
\hline Administration & 24 & 14.37 & 48 & 28.74 & 58 & 34.73 & 69 & 41.32 \\
AACSB & 15 & 18.07 & 28 & 33.73 & 34 & 40.96 & 36 & 43.37 \\
ACBSP & 5 & 10.64 & 10 & 21.28 & 13 & 27.66 & 19 & 40.43 \\
IACBE & 4 & 10.81 & 10 & 27.03 & 11 & 29.73 & 14 & 37.84 \\
Administrative & & & & & & & & \\
Committee & 4 & 2.40 & 1 & 0.60 & 3 & 1.80 & 4 & 2.40 \\
AACSB & 4 & 4.82 & 1 & 1.20 & 3 & 3.61 & 4 & 4.82 \\
ACBSP & 0 & 0.00 & 0 & 0.00 & 0 & 0.00 & 0 & 0.00 \\
IACBE & 0 & 0.00 & 0 & 0.00 & 0 & 0.00 & 0 & 0.00
\end{tabular}

Both Faculty and

Administration

$\begin{array}{llllllll}76 & 45.51 & 59 & 35.33 & 65 & 38.92 & 47 & 28.14\end{array}$

AACSB

$40 \quad 48.19 \quad 35$

$42.17 \quad 33$

$39.76 \quad 28$

33.73

ACBSP

$20 \quad 42.55$

17

$36.17 \quad 20$

$42.55 \quad 14$

29.79

IACBE

$\begin{array}{lll}16 & 43.24 & 7\end{array}$

$18.92 \quad 12$

32.43

5

13.51

Other

$2 \quad 1.20$

0

0.00

0

0.00

0

0.00

AACSB

$1 \quad 1.20$

0

0.00

0

0.00

$\begin{array}{ll}0 & 0.00\end{array}$

ACBSP

$1 \quad 2.13$

0

0.00

0

0.00

$\begin{array}{ll}0 & 0.00\end{array}$

IACBE

$\begin{array}{ll}0 & 0.00\end{array}$

$\begin{array}{ll}0 & 0.00\end{array}$

$\begin{array}{ll}0 & 0.00\end{array}$

0

0.00

Note. Percentages are based on total number of unit respondents and totals in each accreditation agency (Total Unit Respondents $=167, \mathrm{AACSB}=83, \mathrm{ACBSP}=47$ and $\mathrm{IACBE}=37$ ). 
To determine the primary motivation for assessment in the business unit, respondents were asked to select one option from Regional accreditation agency, Business unit decision, Institution policy or recommendation, Specialized accreditation agency, Faculty advocate, and Other. A frequency of each response was conducted by accreditation body to determine the primary assessment motivation (see Table 31$)$. Over $75 \%$ of the responding institutions $(N=$ 124) indicated that accreditation (specialized or regional) was the largest motivation for the creation of an assessment plan and over half $(N=101)$ responded that specialized accreditation was the single largest motivator for the creation of their assessment plan.

Interestingly, nearly $80 \%$ of responding institutions that were AACSB accredited indicated that the specialized accreditation was the main motivation for the creation of their assessment plan and none of their motivation was from regional accreditation. In addition to having stricter accreditation standards, this could also be due to the fact that AACSB has been in existence since 1906 and the call for assessment came after institutions were accredited; therefore, the accrediting body was the impetus for implementing assessment. Units that were accredited later may have had another reason for assessment before they even considered accreditation. The remaining institutions at the Bachelor-level accredited by the other two accreditation agencies also showed the largest motivation from their specialized accreditation, although a lower percentage of responding units compared to AACSB (almost half). Four respondents wrote in and indicated an equal motivation from their specialized and regional accreditation agencies while others indicated motivation from their Board of Governors, institution policy, internal goal to measure outcomes, new president, quality assurance, State Regents for Higher Education, and even less concrete reasons of "we wanted it" or "to improve". 
Table 31

Motivation for Assessment Plan Creation

\begin{tabular}{lcccccccc}
\hline & \multicolumn{2}{c}{ Total } & \multicolumn{2}{c}{ AACSB } & ACBSP & \multicolumn{2}{c}{ IACBE } \\
\cline { 2 - 8 } & $N$ & $\%$ & $N$ & $\%$ & $N$ & $\%$ & $N$ & $\%$ \\
\cline { 2 - 8 } & 5 & 3.05 & 1 & 1.22 & 2 & 4.35 & 2 & 5.56 \\
$\begin{array}{l}\text { Faculty advocate } \\
\begin{array}{l}\text { Business unit } \\
\text { decision }\end{array}\end{array}$ & 11 & 6.71 & 5 & 6.10 & 3 & 6.52 & 3 & 8.33 \\
$\begin{array}{l}\text { Institution policy or } \\
\text { recommendation }\end{array}$ & 11 & 6.71 & 4 & 4.88 & 5 & 10.87 & 2 & 5.56 \\
$\begin{array}{l}\text { Specialized } \\
\text { accreditation agency }\end{array}$ & 101 & 61.59 & 66 & 80.49 & 20 & 43.48 & 15 & 41.67 \\
$\begin{array}{l}\text { Regional } \\
\text { accreditation agency }\end{array}$ & 23 & 14.02 & 0 & 0.00 & 13 & 28.26 & 10 & 27.78 \\
Other & 13 & 7.93 & 6 & 7.32 & 3 & 6.52 & 4 & 11.11 \\
Total & 164 & 100 & 82 & 100 & 46 & 100 & 36 & 100.00 \\
\hline
\end{tabular}

Participants reported the most helpful aid used to facilitate the assessment plans was the specialized accreditation outline. Each response was totaled by accreditation body to determine the assessment plan influences. The Bachelor-level accredited programs indicated a high reliance on the specialized accreditation agencies (see Table 32). Nearly three out of four $(74.7 \%)$ of AACSB accredited institutions relied on their agency outlines, and over seven out of ten (70.3\%) of the IACBE accredited institutions. Interestingly, the ACBSP accredited group relied on their specialized accreditation outlines the least. Only two out of three $(66.0 \%)$ of the Bachelor-level ACBSP accredited units relied on the specialized accreditation agency outlines. Other aids units reported that they used in assessment plan development included AACSB conferences, AACSB peer school data and best practices, advisory councils, assessment training, external stakeholders, 
Malcolm Baldrige National Quality Award Program, results from College of Business, and the University Assessment Committee.

Table 32

Aids Used to Facilitate Assessment Plan Development

\begin{tabular}{|c|c|c|}
\hline & $N$ & $\%$ \\
\hline $\begin{array}{l}\text { Institutional } \\
\text { Guidelines }\end{array}$ & 51 & 30.54 \\
\hline Faculty expertise & 100 & 59.88 \\
\hline $\begin{array}{l}\text { Regional accreditation } \\
\text { outlines }\end{array}$ & 58 & 34.73 \\
\hline External consultants & 45 & 26.95 \\
\hline Internal consultants & 21 & 12.57 \\
\hline $\begin{array}{l}\text { Specialized } \\
\text { accreditation outlines }\end{array}$ & 119 & 71.26 \\
\hline $\begin{array}{l}\text { Other institution } \\
\text { resources }\end{array}$ & 11 & 6.59 \\
\hline
\end{tabular}

Participants reported that most assessment plans were initiated between the years of 1999 and 2006, although the first plans reportedly began in 1980 and the most recent ones developed in 2007 (see Table 33). Over 70\% of the plans were updated during the year of the study or the year prior (2006-2007) (see Table 34). This number is very high. It is double the percentage of units that reported they were at the highest level of assessment planning, which includes making changes to the plan based on feedback. Details on types of updates and changes were not obtained but could provide additional insight into the level of maturity of the assessment plan. 
Table 33

Year Units Began Assessment Plan

\begin{tabular}{ccc}
\hline Year & $\mathrm{N}$ & $\%$ \\
\hline $1980-1984$ & 3 & 1.95 \\
$1985-1989$ & 0 & 0.00 \\
$1990-1994$ & 6 & 3.90 \\
$1995-1999$ & 25 & 16.23 \\
$2000-2004$ & 60 & 38.96 \\
$>2005$ & 60 & 38.96 \\
Total & 154 & 100.00 \\
\hline
\end{tabular}

Table 34

Reported Years of Assessment Plan Updates

\begin{tabular}{ccc}
\hline & $\mathrm{N}$ & $\%$ \\
\hline 2000 & 1 & 0.70 \\
2001 & 1 & 0.70 \\
2002 & 1 & 0.70 \\
2003 & 2 & 1.41 \\
2004 & 3 & 2.11 \\
2005 & 11 & 7.75 \\
2006 & 57 & 40.14 \\
2007 & 66 & 46.48 \\
Total & 142 & 100.0 \\
\hline
\end{tabular}


Over half of the responding units indicated that they use computer resources frequently or very frequently to monitor assessment efforts and results (see Table 35). The most common type of software package reported was spreadsheet software, which was used by 103 units or $61.7 \%$ of respondents. Databases were used by $35.3 \%(N=59)$ and $19.2 \%(N=32)$ used some other type of package including specialized assessment software, the education institution's enterprise package (SCT Banner, etc.), the learning/content management system (WebCT, Blackboard, etc.), statistical packages like SAS or SPSS, Websites, self-developed software, and other office productivity packages (MS Office Word, etc.).

Table 35

Frequency of Computer Resource Usage in Assessment Monitoring

\begin{tabular}{lcc}
\hline Frequency & $\mathrm{N}$ & $\%$ \\
\hline Never & 15 & 9.26 \\
Rarely & 19 & 11.73 \\
Occasionally & 43 & 26.54 \\
Frequently & 50 & 30.86 \\
Very Frequently & 35 & 21.60 \\
Total & 162 & 100 \\
\hline
\end{tabular}

Based on the responses to survey question 83, faculty appear to discuss assessment results at formal retreats about $13 \%$ of the time $(N=38)$ and nearly double that in offices $(N=$ 66). The most common location for discussing assessment results was in regular unit meetings $(N=144)$, which is over twice that of the office discussions (see Table 36). Other locations for 
assessment-related discussions, as written in by participants, were committee meetings, informally, Assessment Day, Town Meeting, and online.

Table 36

\begin{tabular}{ccc}
\multicolumn{3}{l}{ Location of Assessment Discussions } \\
\hline Location & $N$ & $\%$ \\
Offices & 66 & 39.5 \\
Meetings & 144 & 86.2 \\
Retreats & 38 & 22.8 \\
Other & 13 & 7.8
\end{tabular}

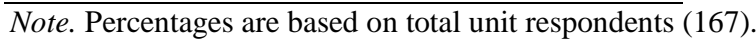

To determine the methods used to distribute results of assessment activities a frequency count by accreditation body of the six possible responses for survey question 84 was conducted. The most common method of distributing results was by presentation $(N=101,60.5 \%)$ followed by websites $(N=43,25.7 \%)$, other methods $(N=38,22.8 \%)$, Newsletters $(N=25,15.0 \%)$, Postal Mail $(N=13,7.8 \%)$, and finally bulletin boards $(N=8,4.8 \%)$ (see Table 37$)$. The other reported items were grouped into similar categories and included other types of reports or hard copy documents $(N=15)$, Email or other electronic media $(N=14)$, other meetings or meeting minutes $(N=8)$, Portfolios $(N=3)$, Classrooms or syllabi $(N=2)$, the library $(N=1)$, and no distribution at all $(N=2)$. 
Table 37

Method of Distribution of Assessment Results

\begin{tabular}{ccc} 
Method & $\mathrm{N}$ & $\%$ \\
\hline Web & 43 & 25.7 \\
Newsletter & 25 & 15.0 \\
Bulletin Board & 8 & 4.8 \\
Presentation & 101 & 60.5 \\
Mail & 13 & 7.8 \\
Other & 38 & 22.8 \\
\hline Note. Percentages are based on total unit respondents (167).
\end{tabular}

The final demographic survey question, 93, asked the degree to which accreditation efforts have impacted assessment efforts. The mean response was $4.35(S D=0.778)$. One hundred seventy-three respondents $(58.9 \%)$ indicated that they perceived that the impact accreditation had on their assessment efforts was either high or very high (see Table 38). Over half of the AACSB and ACBSP accredited units indicated that accreditation agency had a very high impact on their assessment efforts, while less than one third of IACBE selected very high. The majority of IACBE accredited units selected high. 
Table 38

Perceived Impact Accreditation has on Assessment Efforts

\begin{tabular}{ccccccccc}
\hline & \multicolumn{2}{c}{ Total } & \multicolumn{2}{c}{ AACSB } & \multicolumn{2}{c}{ ACBSP } & \multicolumn{2}{c}{ IACBE } \\
\hline & $N$ & $\%$ & $N$ & $\%$ & $N$ & $\%$ & $N$ & $\%$ \\
\hline Very High & 50.31 & 26 & 55.32 & 12 & 33.33 & 43 & 55.84 & 50.31 \\
High & 37.89 & 17 & 36.17 & 21 & 58.33 & 22 & 28.57 & 37.89 \\
Moderate & 9.32 & 2 & 4.26 & 2 & 5.56 & 11 & 14.29 & 9.32 \\
Low & 1.86 & 1 & 2.13 & 1 & 2.78 & 1 & 1.30 & 1.86 \\
Very Low & 0.62 & 1 & 2.13 & 0 & 0.00 & 0 & 0.00 & 0.62 \\
Total & 100.00 & 47 & 100.00 & 36 & 100.00 & 77 & 100.00 & 100.00 \\
\hline
\end{tabular}

Research Question 1

To what degree do accredited business schools follow the best practices in assessment?

The mean responses of the questions by each assessment principle were calculated to indicate the level that accredited business schools followed each principle. Respondents were asked to rate their unit's assessment on a Likert scale where 1 was a low-level response of either "not clear at all", "never", or "strongly disagree" and 5 was the highest possible option of "very clear", "very frequent", or "strongly agree". The means, grouped by principle, indicate the degree to which the unit follows the assessment principle of good practice. Principle 1 had the highest mean response but also the largest standard deviation $(M=4.34 S D=.74)$. Accredited business schools seemed to follow Principles 1, 3, 5, and 7 the most as those had means above 4.0, indicating a high level of practical application of Principle 1 (see Table 39). The remaining Principles all had means above 3.0 indicating that accredited business schools generally follow 
assessment principles of best practice consistently at a moderate to high level (the range of SD was from .55 to .74$)$. The following detail provides information pertaining to the individual Principles.

Table 39

Means of Questions Grouped by Principle

\begin{tabular}{lll}
\hline & $M$ & $S D$ \\
\hline Principle 1 & 4.34 & 0.74 \\
Principle 2 & 3.43 & 0.58 \\
Principle 3 & 4.05 & 0.62 \\
Principle 4 & 3.59 & 0.61 \\
Principle 5 & 4.07 & 0.59 \\
Principle 6 & 3.74 & 0.62 \\
Principle 7 & 4.05 & 0.55 \\
Principle 8 & 3.35 & 0.66 \\
Principle 9 & 3.49 & 0.58 \\
\hline
\end{tabular}

Principle 1. The assessment of student learning begins with educational values. The question responses in this area determine the level the unit's student learning outcomes are based on the strategic direction of the institution and the unit. Two survey questions (7 and 17) were analyzed to determine the degree the institution and unit missions were reflected within the stated outcomes or assessment activities. The frequencies of responses were evaluated as well as the mean, based on corresponding values ranging from 5 to 1 , where 5 was a very clear indication of mission in the outcomes and 1 was no clear relationship. The mean was expected to be somewhat high as all institutions and business units have missions that should ideally be 
connected with their assessments (Eaton, 2005). The mean for institution mission connection was $4.22(N=157, S D=0.92)$. The unit means reported a closer reflection with a mean of 4.48 $(\mathrm{N}=162 \mathrm{SD}=0.75)$. Over half $(57.1 \%)$ of the units indicated that the mission of their unit was very clear in their assessment activities (see Table 40). While the institution mission was reflection was lower, nearly half $(47.7 \%)$ of the institutions indicated a very clear reflection in assessment activities (see Table 40). When analyzing the principle as a whole, the mean was 4.34 $(S D=0.74)$, indicating a strong connection of student learning to the educational values.

Table 40

Principle 1 - Institution and Unit Mission Reflection in Outcomes and Assessments

\begin{tabular}{lcccc}
\hline & \multicolumn{2}{c}{ Institution } & \multicolumn{2}{c}{ Unit } \\
\cline { 2 - 5 } & $N$ & $\%$ & 7 & $\%$ \\
\cline { 2 - 5 } Very Clear & 93 & 57.4 & 9 & 47.1 \\
Somewhat Clear & 3 & 1.9 & 54 & 5.7 \\
Neither Clear nor Unclear & 60 & 37.0 & 1 & 34.4 \\
Somewhat Unclear & 2 & 1.2 & 19 & 12.1 \\
Not Clear at All & 4 & 2.5 & 157 & 100.0 \\
Total & 162 & 100.0 & 5 \\
\hline
\end{tabular}

Principle 2. This principle examined at assessment and its effectiveness. Effectiveness here is defined as reflecting an understanding of learning as multidimensional, integrated, and revealed in performance over time. To answer this question, frequency and means analysis were used to determine the use of direct (question 42a) and indirect (question 42b) assessment methods and also the results of the remaining questions $(41,59,61,62,63,66,67$, and 68$)$ for 
this Principle. Because question 41 was multi-part, four different means analyses were conducted. The first looked at the direct assessments, the second the indirect assessments, the third the general questions related to the Principle, and the fourth was a combination of the previous three, or the Principle as a whole. Direct assessments seemed to be the most common assessment performed with a mean of $3.44(N=165, S D=0.86)$. Indirect assessments had a mean of $3.07(N=166, S D=0.91)$. Respondents indicated that the general assessment practices associated with Principle 2 were activities common in accredited business schools as the mean of general questions was $3.79(N=167, S D=0.50)$. Overall, the mean of Principle 2 was $3.43(N=$ $167, S D=0.58)$.

The most common direct assessment was written exams which was used often to very frequently by $70.06 \%$ of the responding units. Oral exams were the least popular direct assessment reported to be used rarely or never by $51.53 \%$ of the responding units (see Table 41 ). The most common indirect assessment was course evaluations used often or very frequently by $67.67 \%$ of the reporting institutions (see Table 42). Finally, assessment questions that were focused on this principle as a whole asked about learning as multidimensional, integrated, and revealed in performance over time. Responses were generally high across all units for all questions (see Table 43). The only exception was the use of psychomotor skills as only $20.36 \%$ indicated that they assess these skills often or very frequently. 
Table 41

Principle 2-Use of Direct Assessment Methods

\begin{tabular}{|c|c|c|c|c|c|c|c|c|c|c|c|c|c|c|c|c|}
\hline & \multicolumn{2}{|c|}{$\begin{array}{c}\text { Very } \\
\text { Frequently }\end{array}$} & \multicolumn{2}{|c|}{ Often } & \multicolumn{2}{|c|}{ Occasionally } & \multicolumn{2}{|c|}{ Rarely } & \multicolumn{2}{|c|}{ Never } & \multicolumn{2}{|c|}{$\begin{array}{c}\text { Total } \\
\text { Responses }\end{array}$} & \multicolumn{2}{|c|}{$\begin{array}{c}\text { No } \\
\text { Response }\end{array}$} & \multicolumn{2}{|c|}{ Total } \\
\hline & $N$ & $\%$ & $N$ & $\%$ & $N$ & $\%$ & $N$ & $\%$ & $N$ & $\%$ & $N$ & $\%$ & $N$ & $\%$ & $N$ & $\%$ \\
\hline Written Exams & 58 & 34.73 & 59 & 35.33 & 16 & 9.58 & 3 & 1.8 & 15 & 8.98 & 151 & 90.42 & 16 & 9.58 & 167 & 100 \\
\hline Quizzes & 34 & 20.36 & 43 & 25.75 & 22 & 13.17 & 10 & 5.99 & 25 & 14.97 & 134 & 80.24 & 33 & 19.76 & 167 & 100 \\
\hline Commercial Exams & 59 & 35.33 & 32 & 19.16 & 21 & 12.57 & 10 & 5.99 & 26 & 15.57 & 148 & 88.62 & 19 & 11.38 & 167 & 100 \\
\hline Oral Exams & 7 & 4.19 & 17 & 10.18 & 21 & 12.57 & 30 & 17.96 & 56 & 33.53 & 131 & 78.44 & 36 & 21.56 & 167 & 100 \\
\hline Written Problems & 26 & 15.57 & 44 & 26.35 & 47 & 28.14 & 11 & 6.59 & 14 & 8.38 & 142 & 85.03 & 25 & 14.97 & 167 & 100 \\
\hline $\begin{array}{l}\text { Thesis or Term } \\
\text { Papers }\end{array}$ & 29 & 17.37 & 43 & 25.75 & 35 & 20.96 & 10 & 5.99 & 23 & 13.77 & 140 & 83.83 & 27 & 16.17 & 167 & 100 \\
\hline Projects & 45 & 26.95 & 57 & 34.13 & 32 & 19.16 & 4 & 2.4 & 11 & 6.59 & 149 & 89.22 & 18 & 10.78 & 167 & 100 \\
\hline $\begin{array}{l}\text { Case Studies and } \\
\text { Simulations }\end{array}$ & 35 & 20.96 & 67 & 40.12 & 27 & 16.17 & 4 & 2.4 & 14 & 8.38 & 147 & 88.02 & 20 & 11.98 & 167 & 100 \\
\hline Presentations & 41 & 24.55 & 59 & 35.33 & 32 & 19.16 & 5 & 2.99 & 15 & 8.98 & 152 & 91.02 & 15 & 8.98 & 167 & 100 \\
\hline Portfolios & 9 & 5.39 & 15 & 8.98 & 24 & 14.37 & 32 & 19.16 & 53 & 31.74 & 133 & 79.64 & 34 & 20.36 & 167 & 100 \\
\hline $\begin{array}{l}\text { Internships/Practicum } \\
\text { Evaluations }\end{array}$ & 28 & 16.77 & 37 & 22.16 & 24 & 14.37 & 13 & 7.78 & 40 & 23.95 & 142 & 85.03 & 25 & 14.97 & 167 & 100 \\
\hline Other & 7 & 4.19 & 6 & 3.59 & 5 & 2.99 & 1 & 0.6 & 17 & 10.18 & 36 & 21.56 & 131 & 78.44 & 167 & 100 \\
\hline
\end{tabular}


Table 42

Principle 2 - Use of Indirect Assessment Methods

\begin{tabular}{|c|c|c|c|c|c|c|c|c|c|c|c|c|c|c|c|c|}
\hline & \multicolumn{2}{|c|}{$\begin{array}{c}\text { Very } \\
\text { Frequently }\end{array}$} & \multicolumn{2}{|c|}{ Often } & \multicolumn{2}{|c|}{ Occasionally } & \multicolumn{2}{|c|}{ Rarely } & \multicolumn{2}{|c|}{ Never } & \multicolumn{2}{|c|}{$\begin{array}{c}\text { Total } \\
\text { Responses }\end{array}$} & \multicolumn{2}{|c|}{$\begin{array}{c}\text { No } \\
\text { Response }\end{array}$} & \multicolumn{2}{|c|}{ Total } \\
\hline & $N$ & $\%$ & $N$ & $\%$ & $N$ & $\%$ & $N$ & $\%$ & $N$ & $\%$ & $N$ & $\%$ & $N$ & $\%$ & $N$ & $\%$ \\
\hline $\begin{array}{l}\text { Reflections or } \\
\text { Journals }\end{array}$ & 4 & 2.4 & 17 & 10.18 & 21 & 12.57 & 24 & 14.37 & 68 & 40.72 & 134 & 80.24 & 33 & 19.76 & 167 & 100 \\
\hline Entrance Interviews & 3 & 1.8 & 7 & 4.19 & 12 & 7.19 & 17 & 10.18 & 93 & 55.69 & 132 & 79.04 & 35 & 20.96 & 167 & 100 \\
\hline Exit Interviews & 30 & 17.96 & 34 & 20.36 & 28 & 16.77 & 13 & 7.78 & 39 & 23.35 & 144 & 86.23 & 23 & 13.77 & 167 & 100 \\
\hline Focus Groups & 6 & 3.59 & 19 & 11.38 & 38 & 22.75 & 21 & 12.57 & 55 & 32.93 & 139 & 83.23 & 28 & 16.77 & 167 & 100 \\
\hline Employer Surveys & 17 & 10.18 & 41 & 24.55 & 50 & 29.94 & 21 & 12.57 & 24 & 14.37 & 153 & 91.62 & 14 & 8.38 & 167 & 100 \\
\hline $\begin{array}{l}\text { Student Satisfaction } \\
\text { Surveys }\end{array}$ & 60 & 35.93 & 54 & 32.34 & 27 & 16.17 & 6 & 3.59 & 14 & 8.38 & 161 & 96.41 & 6 & 3.59 & 167 & 100 \\
\hline Alumni Surveys & 28 & 16.77 & 47 & 28.14 & 47 & 28.14 & 20 & 11.98 & 16 & 9.58 & 158 & 94.61 & 9 & 5.39 & 167 & 100 \\
\hline Course Evaluations & 70 & 41.92 & 43 & 25.75 & 19 & 11.38 & 3 & 1.8 & 17 & 10.18 & 152 & 91.02 & 15 & 8.98 & 167 & 100 \\
\hline Other & 6 & 3.59 & 2 & 1.2 & 0 & 0 & 2 & 1.2 & 15 & 8.98 & 25 & 14.97 & 142 & 85.03 & 167 & 100 \\
\hline
\end{tabular}


Table 43

Principle 2 - Indication that Learning is Multidimensional, Integrated, and Revealed in Performance Over Time

\begin{tabular}{|c|c|c|c|c|c|c|c|c|c|c|c|c|c|c|c|c|}
\hline \multirow{3}{*}{$\begin{array}{l}\text { Rubrics/Defined } \\
\text { Performance Levels }\end{array}$} & \multicolumn{2}{|c|}{$\begin{array}{c}\text { Very } \\
\text { Frequently }\end{array}$} & \multicolumn{2}{|c|}{ Often } & \multicolumn{2}{|c|}{ Occasionally } & \multicolumn{2}{|c|}{ Rarely } & \multicolumn{2}{|c|}{ Never } & \multicolumn{2}{|c|}{$\begin{array}{c}\text { Total } \\
\text { Responses } \\
\end{array}$} & \multicolumn{2}{|c|}{$\begin{array}{c}\text { No } \\
\text { Response } \\
\end{array}$} & \multicolumn{2}{|c|}{ Total } \\
\hline & $N$ & $\%$ & $N$ & $\%$ & $N$ & $\%$ & $N$ & $\%$ & $N$ & $\%$ & $N$ & $\%$ & $N$ & $\%$ & $N$ & $\%$ \\
\hline & 56 & 33.53 & 55 & 32.93 & 33 & 19.76 & 6 & 3.59 & 5 & 2.99 & 155 & 92.81 & 12 & 7.19 & 167 & 100 \\
\hline & \multicolumn{2}{|c|}{$\begin{array}{l}\text { Strongly } \\
\text { Agree }\end{array}$} & \multicolumn{2}{|c|}{ Agree } & \multicolumn{2}{|c|}{ Neutral } & \multicolumn{2}{|c|}{ Disagree } & \multicolumn{2}{|c|}{$\begin{array}{l}\text { Strongly } \\
\text { Disagree }\end{array}$} & \multicolumn{2}{|c|}{$\begin{array}{c}\text { Total } \\
\text { Responses } \\
\end{array}$} & \multicolumn{2}{|c|}{$\begin{array}{c}\text { No } \\
\text { Response }\end{array}$} & \multicolumn{2}{|c|}{ Total } \\
\hline & $N$ & $\%$ & $N$ & $\%$ & $N$ & $\%$ & $N$ & $\%$ & $N$ & $\%$ & $N$ & $\%$ & $N$ & $\%$ & $N$ & $\%$ \\
\hline $\begin{array}{l}\text { Plan Measures } \\
\text { Multiple Learning } \\
\text { Objectives }\end{array}$ & 68 & 40.72 & 86 & 51.50 & 10 & 5.99 & 1 & 0.60 & 0 & 0.00 & 165 & 98.80 & 2 & 1.20 & 167 & 100 \\
\hline $\begin{array}{l}\text { Students are Assessed } \\
\text { at Multiple Points }\end{array}$ & 61 & 36.53 & 74 & 44.31 & 11 & 6.59 & 18 & 10.78 & 1 & 0.60 & 165 & 98.80 & 2 & 1.20 & 167 & 100 \\
\hline $\begin{array}{l}\text { Assessment is } \\
\text { Integrated Across } \\
\text { Business Core }\end{array}$ & 67 & 40.12 & 73 & 43.71 & 12 & 7.19 & 11 & 6.59 & 1 & 0.60 & 164 & 98.20 & 3 & 1.80 & 167 & 100 \\
\hline $\begin{array}{l}\text { Individual Functional } \\
\text { Areas Assess }\end{array}$ & 44 & 26.35 & 72 & 43.11 & 22 & 13.17 & 21 & 12.57 & 5 & 2.99 & 164 & 98.20 & 3 & 1.80 & 167 & 100 \\
\hline $\begin{array}{l}\text { Assessment Measures } \\
\text { Affective Skills }\end{array}$ & 15 & 8.98 & 56 & 33.53 & 42 & 25.15 & 39 & 23.35 & 11 & 6.59 & 163 & 97.60 & 4 & 2.40 & 167 & 100 \\
\hline $\begin{array}{l}\text { Assessment Measures } \\
\text { Cognitive Skills }\end{array}$ & 52 & 31.14 & 99 & 59.28 & 10 & 5.99 & 2 & 1.20 & 0 & 0.00 & 163 & 97.60 & 4 & 2.40 & 167 & 100 \\
\hline $\begin{array}{l}\text { Assessment Measures } \\
\text { Psychomotor Skills }\end{array}$ & 7 & 4.19 & 27 & 16.17 & 45 & 26.95 & 49 & 29.34 & 35 & 20.96 & 163 & 97.60 & 4 & 2.40 & 167 & 100 \\
\hline
\end{tabular}


Principle 3. Assessment works best when the programs it seeks to improve have clear, explicitly stated purposes. This principle focuses on if the assessment plans in the units had clear, explicitly stated purposes. To analyze this principle, questions $48,50,51,52,53,60$ on the survey instrument were evaluated. The mean response to the Principle 3 questions was 4.05 (SD $=0.62$ ). This high mean indicates that the business units have clear and explicitly stated purposes for their programs. The earlier analysis of Principle 1 indicated a high positive response rate concerning the clarity of the mission in assessment activities. This supports and triangulates, with Principle 1 questions 7 and 17, which indicated that institutions are using assessment to reach the mission and goals of the unit and institution. The positive response rate for Principle 1 was slightly higher at the unit level compared to the institution (see Table 40). Responses for Principle 3, concerning the explicit statement or purpose, were also higher at the unit level. as over $30 \%$ strongly agreed, nearly half agreed, and approximately $20 \%$ were either neutral or disagreed at some level with the statements.

The two areas that had the highest percentage of negative responses concerned stated assessment measures or goals. Over one-third of respondents indicated that did not state the goals of individual assessment activities in their assessment plan and over one-fourth indicated that they did not state objective measures clearly in their assessment plan. 
Table 44

Principle 3 - Extent Programs Have Clear, Explicitly Stated Purposes

\begin{tabular}{|c|c|c|c|c|c|c|c|c|c|c|c|c|c|c|c|c|}
\hline & \multicolumn{2}{|c|}{$\begin{array}{l}\text { Strongly } \\
\text { Agree }\end{array}$} & \multicolumn{2}{|c|}{ Agree } & \multicolumn{2}{|c|}{ Neutral } & \multicolumn{2}{|c|}{ Disagree } & \multicolumn{2}{|c|}{$\begin{array}{l}\text { Strongly } \\
\text { Disagree }\end{array}$} & \multicolumn{2}{|c|}{ Total } & \multicolumn{2}{|c|}{ No Response } & \multicolumn{2}{|c|}{ Total } \\
\hline & $N$ & $\%$ & $N$ & $\%$ & $N$ & $\%$ & $N$ & $\%$ & $N$ & $\%$ & $N$ & $\%$ & $N$ & $\%$ & $N$ & $\%$ \\
\hline $\begin{array}{l}\text { Assessment Plan has } \\
\text { Clear Goals }\end{array}$ & 58 & 34.73 & 78 & 46.71 & 24 & 14.37 & 5 & 2.99 & 1 & 0.60 & 166 & 99.40 & 1 & 0.60 & 167 & 100 \\
\hline $\begin{array}{l}\text { Assessment Plan has } \\
\text { Clear Student Learning } \\
\text { Outcomes }\end{array}$ & 56 & 33.53 & 77 & 46.11 & 24 & 14.37 & 8 & 4.79 & 0 & 0.00 & 165 & 98.80 & 2 & 1.20 & 167 & 100 \\
\hline $\begin{array}{l}\text { Objective Measures are } \\
\text { Stated Clearly in Plan }\end{array}$ & 44 & 26.35 & 78 & 46.71 & 32 & 19.16 & 10 & 5.99 & 2 & 1.20 & 166 & 99.40 & 1 & 0.60 & 167 & 100 \\
\hline $\begin{array}{l}\text { Outcomes are Connected } \\
\text { to Unit Mission, Vision, } \\
\text { and Goals }\end{array}$ & 64 & 38.32 & 84 & 50.30 & 15 & 8.98 & 4 & 2.40 & 0 & 0.00 & 167 & 100.00 & 0 & 0.00 & 167 & 100 \\
\hline $\begin{array}{l}\text { Outcomes are Connected } \\
\text { to Institution Mission, } \\
\text { Vision, and Goals }\end{array}$ & 53 & 31.74 & 90 & 53.89 & 19 & 11.38 & 5 & 2.99 & 0 & 0.00 & 167 & 100.00 & 0 & 0.00 & 167 & 100 \\
\hline $\begin{array}{l}\text { Assessment Plan } \\
\text { Indicates Goals of } \\
\text { Individual Assessments }\end{array}$ & 30 & 17.96 & 79 & 47.31 & 38 & 22.75 & 14 & 8.38 & 0 & 0.00 & 161 & 96.41 & 6 & 3.59 & 167 & 100 \\
\hline
\end{tabular}




\section{Principle 4. Assessment requires attention to outcomes but also and equally to the}

experiences that lead to those outcomes. This means that assessment should not just focus on the results but should also be concerned with the student experiences and activities that are designed to achieve the outcome. Questions $69,70,71$, and 75 were evaluated using frequency and means analysis to determine the extent Principle 4 was practiced. The mean response for Principle 4 was $3.59(S D=0.61)$. This indicates that attention is generally given to the experiences leading to outcomes but additional attention could be given. Although the responses were mostly positive for this principle, less than one-third of respondents indicated that they considered teaching styles when planning assessment activities. Just over half agree that they consider student experiences in assessment development. On the positive side, nearly $90 \%$ agree that they consider curriculum content when planning assessment activities. Two-thirds (65.87\%) either agreed or strongly agreed that they did consider the purpose of assessment and only $10.78 \%$ disagreed or strongly disagreed (see Table 45). 
Table 45

Principle 4-Level of Attention Given to the Student Experiences that Lead to Outcomes

\begin{tabular}{|c|c|c|c|c|c|c|c|c|c|c|c|c|c|c|c|c|}
\hline & \multicolumn{2}{|c|}{$\begin{array}{c}\text { Strongly } \\
\text { Agree }\end{array}$} & \multicolumn{2}{|c|}{ Agree } & \multicolumn{2}{|c|}{ Neutral } & \multicolumn{2}{|c|}{ Disagree } & \multicolumn{2}{|c|}{$\begin{array}{l}\text { Strongly } \\
\text { Disagree }\end{array}$} & \multicolumn{2}{|c|}{ Total } & \multicolumn{2}{|c|}{$\begin{array}{c}\text { No } \\
\text { Response }\end{array}$} & \multicolumn{2}{|c|}{ Total } \\
\hline & $N$ & $\%$ & $N$ & $\%$ & $N$ & $\%$ & $N$ & $\%$ & $N$ & $\%$ & $N$ & $\%$ & $N$ & $\%$ & $N$ & $\%$ \\
\hline $\begin{array}{l}\text { Assessment } \\
\text { Development } \\
\text { Considers Student } \\
\text { Experiences }\end{array}$ & 20 & 11.98 & 70 & 41.92 & 53 & 31.74 & 18 & 10.78 & 2 & 1.20 & 163 & 97.60 & 4 & 2.40 & 167 & 100 \\
\hline $\begin{array}{l}\text { Assessment } \\
\text { Development } \\
\text { Considers Curriculum } \\
\text { Content }\end{array}$ & 50 & 29.94 & 99 & 59.28 & 12 & 7.19 & 3 & 1.80 & 1 & 0.60 & 165 & 98.80 & 2 & 1.20 & 167 & 100 \\
\hline $\begin{array}{l}\text { Assessment } \\
\text { Development } \\
\text { Considers Teaching } \\
\text { Styles }\end{array}$ & 10 & 5.99 & 44 & 26.35 & 61 & 36.53 & 38 & 22.75 & 12 & 7.19 & 165 & 98.80 & 2 & 1.20 & 167 & 100 \\
\hline $\begin{array}{l}\text { Assessment Purpose is } \\
\text { Considered when } \\
\text { Planning Assessment } \\
\text { Activities }\end{array}$ & 17 & 10.18 & 93 & 55.69 & 32 & 19.16 & 12 & 7.19 & 6 & 3.59 & 160 & 95.81 & 7 & 4.19 & 167 & 100 \\
\hline
\end{tabular}


Principle 5. Assessment works best when it is ongoing not episodic. Frequency and means analysis were conducted on the four questions that address assessment as a continuous process $(72,73,79$, and 80$)$. The mean response for Principle 5 was $4.07(S D=0.59)$. Overall these questions were rated highly among the respondents (see Table 46). In fact, for the four questions in this category, three-fourths of the responses were positive. Only a very small number (less than 5\%) of the units disagreed or strongly disagreed with the questions in this category. Over one third of the units (34.13\%) strongly agreed that assessment is an ongoing process and over half agreed (53.29\%). Although still right at three-fourths (74.85\%), the lowest valued question in this group was the statement that assessment results are compared over time and verify progression toward goals. 
Table 46

Principle 5 - Assessment as an Ongoing Process

\begin{tabular}{|c|c|c|c|c|c|c|c|c|c|c|c|c|c|c|c|c|}
\hline & \multicolumn{2}{|c|}{$\begin{array}{l}\text { Strongly } \\
\text { Agree }\end{array}$} & \multicolumn{2}{|c|}{ Agree } & \multicolumn{2}{|c|}{ Neutral } & \multicolumn{2}{|c|}{ Disagree } & \multicolumn{2}{|c|}{$\begin{array}{l}\text { Strongly } \\
\text { Disagree }\end{array}$} & \multicolumn{2}{|c|}{ Total } & \multicolumn{2}{|c|}{ No Response } & \multicolumn{2}{|c|}{ Total } \\
\hline & $N$ & $\%$ & $N$ & $\%$ & $N$ & $\%$ & $N$ & $\%$ & $N$ & $\%$ & $N$ & $\%$ & $N$ & $\%$ & $N$ & $\%$ \\
\hline $\begin{array}{l}\text { Assessment is On- } \\
\text { Going Continuous } \\
\text { Improvement Process }\end{array}$ & 57 & 34.13 & 89 & 53.29 & 14 & 8.38 & 3 & 1.80 & 1 & 0.60 & 164 & 98.20 & 3 & 1.80 & 167 & 100 \\
\hline $\begin{array}{l}\text { Assessment Process is } \\
\text { Evaluated Periodically }\end{array}$ & 36 & 21.56 & 93 & 55.69 & 26 & 15.57 & 7 & 4.19 & 1 & 0.60 & 163 & 97.60 & 4 & 2.40 & 167 & 100 \\
\hline $\begin{array}{l}\text { Assessment Results are } \\
\text { Compared Over Time } \\
\text { and Verify Progression } \\
\text { Toward Goals }\end{array}$ & 37 & 22.16 & 88 & 52.69 & 28 & 16.77 & 8 & 4.79 & 0.0 & 0.00 & 161 & 96.41 & 6 & 3.59 & 167 & 100 \\
\hline $\begin{array}{l}\text { Improvements are } \\
\text { Made Based on } \\
\text { Assessment Results }\end{array}$ & 49 & 29.34 & 92 & 55.09 & 19 & 11.38 & 1 & 0.60 & .00 & 0.00 & 161 & 96.41 & 6 & 3.59 & 167 & 100 \\
\hline
\end{tabular}


Principle 6. Assessment fosters wider improvement when representatives from across the educational community are involved. The questions in this grouping sought to determine the involvement of others in assessment in the surveyed units. Questions 44, 54, 58, and 74 were analyzed using frequency and means analysis. The mean response for Principle 6 was $3.74(S D=$ 0.62). While the largest group of responses to this question was positive, many of the responses were also neutral or disagree. In response to the inclusion of individuals beyond the campus community in assessment, although over half (62.38\%) did respond positively, nearly $20 \%$ were neutral. Over one-third (40.12\%) of those responding to the question asking if assessment was a group faculty effort disagreed or were neutral. Assessment did appear to be viewed as a campus wide-effort as over three-fourths of the responding units either agreed or strongly agreed with that statement. Finally, although over two-thirds of the units indicated that unit outcomes were developed by discipline collaboration, there was not a strong agreement. In fact, there were nearly equal amounts (approximately 20\%) that strongly agreed and were neutral (see Table 47). 
Table 47

Principle 6-Assessment Collaboration Across Campus Community

\begin{tabular}{|c|c|c|c|c|c|c|c|c|c|c|c|c|c|c|c|c|}
\hline & \multicolumn{2}{|c|}{$\begin{array}{c}\text { Strongly } \\
\text { Agree }\end{array}$} & \multicolumn{2}{|c|}{ Agree } & \multicolumn{2}{|c|}{ Neutral } & \multicolumn{2}{|c|}{ Disagree } & \multicolumn{2}{|c|}{$\begin{array}{l}\text { Strongly } \\
\text { Disagree }\end{array}$} & \multicolumn{2}{|c|}{ Total } & \multicolumn{2}{|c|}{ No Response } & \multicolumn{2}{|c|}{ Total } \\
\hline & $N$ & $\%$ & $N$ & $\%$ & $N$ & $\%$ & $N$ & $\%$ & $N$ & $\%$ & $N$ & $\%$ & $N$ & $\%$ & $N$ & $\%$ \\
\hline $\begin{array}{l}\text { Assessment Effort is } \\
\text { Campus Wide }\end{array}$ & 55 & 32.93 & 73 & 43.71 & 18 & 10.78 & 14 & 8.38 & 4 & 2.40 & 164 & 98.20 & 3 & 1.80 & 167 & 100 \\
\hline $\begin{array}{l}\text { Whole Faculty } \\
\text { Participates - Not } \\
\text { Individual Effort }\end{array}$ & 29 & 17.37 & 69 & 41.32 & 38 & 22.75 & 26 & 15.57 & 3 & 1.80 & 165 & 98.80 & 2 & 1.20 & 167 & 100 \\
\hline $\begin{array}{l}\text { Unit Outcomes are } \\
\text { Developed by } \\
\text { Discipline } \\
\text { Collaboration }\end{array}$ & 33 & 19.76 & 83 & 49.70 & 34 & 20.36 & 13 & 7.78 & 0 & 0.00 & 163 & 97.60 & 4 & 2.40 & 167 & 100 \\
\hline $\begin{array}{l}\text { Individuals Beyond } \\
\text { campus Community } \\
\text { are Included in } \\
\text { Assessment Process }\end{array}$ & 18 & 10.78 & 86 & 51.50 & 33 & 19.76 & 20 & 11.98 & 7 & 4.19 & 164 & 98.20 & 3 & 1.80 & 167 & 100 \\
\hline
\end{tabular}


Principle 7. Assessment makes a difference when it begins with issues of use and

illustrates questions that people really care about. This area looked at the ability of assessment to make a difference and the belief that in order for it to do so, it should focus on issues of use and importance. The four questions for this principle were analyzed using frequency and means analysis (questions 47, 55, 56, and 77). The mean response of Principle 7 was $4.05(S D=0.55)$.

The units indicated that they agreed (43.71\% or strongly agreed (37.72\%) assessment results are shared with faculty and none of the units strongly disagreed. Less than $2 \%$ of those responding believed that their outcomes failed to focus on improving learner knowledge (none strongly disagreed but $1.80 \%$ disagreed). Over $80 \%$ agreed or strongly agreed that the measured items are important and relevant to the unit decision making and approximately three-fourths (74.85\%) indicated that their outcomes were learner centered (agreed or strongly agreed) (see Table 48). 
Table 48

Principle 7 - Assessment Impact on Items of Importance

\begin{tabular}{|c|c|c|c|c|c|c|c|c|c|c|c|c|c|c|c|c|}
\hline & \multicolumn{2}{|c|}{$\begin{array}{l}\text { Strongly } \\
\text { Agree }\end{array}$} & \multicolumn{2}{|c|}{ Agree } & \multicolumn{2}{|c|}{ Neutral } & \multicolumn{2}{|c|}{ Disagree } & \multicolumn{2}{|c|}{$\begin{array}{l}\text { Strongly } \\
\text { Disagree }\end{array}$} & \multicolumn{2}{|c|}{ Total } & \multicolumn{2}{|c|}{ No Response } & \multicolumn{2}{|c|}{ Total } \\
\hline & $N$ & $\%$ & $N$ & $\%$ & $N$ & $\%$ & $N$ & $\%$ & $N$ & $\%$ & $N$ & $\%$ & $N$ & $\%$ & $N$ & $\%$ \\
\hline $\begin{array}{l}\text { Measured Items are } \\
\text { Important and } \\
\text { Relevant to Unit } \\
\text { Decision Making }\end{array}$ & 37 & 22.16 & 100 & 59.88 & 22 & 13.17 & 6 & 3.59 & 1 & 0.60 & 166 & 99.40 & 1 & 0.60 & 167 & 100 \\
\hline $\begin{array}{l}\text { Outcomes are Learner- } \\
\text { Centered }\end{array}$ & 30 & 17.96 & 95 & 56.89 & 33 & 19.76 & 7 & 4.19 & .0 & 0.00 & 165 & 98.80 & 2 & 1.20 & 167 & 100 \\
\hline $\begin{array}{l}\text { Outcomes Focus on } \\
\text { Improving Learner } \\
\text { Knowledge }\end{array}$ & 43 & 25.75 & 104 & 62.28 & 15 & 8.98 & 3 & 1.80 & 0 & 0.00 & 165 & 98.80 & 2 & 1.20 & 167 & 100 \\
\hline $\begin{array}{l}\text { Assessment Results } \\
\text { are Shared with } \\
\text { Faculty }\end{array}$ & 63 & 37.72 & 73 & 43.71 & 17 & 10.18 & 9 & 5.39 & 0 & 0.00 & 162 & 97.01 & 5 & 2.99 & 167 & 100 \\
\hline
\end{tabular}


Principle 8. Assessment is most likely to lead to improvement when it is part of a larger set of conditions that promote change. Four questions (45 46, 64, and 65) were analyzed using frequency and means analysis. The mean response for Principle 8 was $3.35(S D=0.66)$. Nearly two-thirds $(62.87 \%)$ of units disagreed or strongly disagreed that faculty were provided incentive to participate in assessment activities. Less than $2 \%$ indicated strongly that faculty incentives were provided. Nearly $80 \%$ of the units agreed or strongly agreed that assessment was part of their strategic plan and, while $6.59 \%$ disagreed, none strongly disagreed. Approximately three fourths of the units indicated that assessment was part of their internal program review process. While over half $(53.89 \%)$ of the units indicated that assessment was part of their culture, over 20\% disagreed (see Table 49). 
Table 49

Principle 8-Assessment as a Change Agent

\begin{tabular}{|c|c|c|c|c|c|c|c|c|c|c|c|c|c|c|c|c|}
\hline & \multicolumn{2}{|c|}{$\begin{array}{l}\text { Strongly } \\
\text { Agree }\end{array}$} & \multicolumn{2}{|c|}{ Agree } & \multicolumn{2}{|c|}{ Neutral } & \multicolumn{2}{|c|}{ Disagree } & \multicolumn{2}{|c|}{$\begin{array}{l}\text { Strongly } \\
\text { Disagree }\end{array}$} & \multicolumn{2}{|c|}{ Total } & \multicolumn{2}{|c|}{ No Response } & \multicolumn{2}{|c|}{ Total } \\
\hline & $N$ & $\%$ & $N$ & $\%$ & $N$ & $\%$ & $N$ & $\%$ & $N$ & $\%$ & $N$ & $\%$ & $N$ & $\%$ & $N$ & $\%$ \\
\hline $\begin{array}{l}\text { Assessment is Part of } \\
\text { Culture }\end{array}$ & 30 & 17.96 & 60 & 35.93 & 41 & 24.55 & 31 & 18.56 & 3 & 1.80 & 165 & 98.80 & 2 & 1.20 & 167 & 100 \\
\hline Faculty Incentives & 3 & 1.80 & 25 & 14.97 & 34 & 20.36 & 74 & 44.31 & 31 & 18.56 & 167 & 100.00 & 0 & 0.00 & 167 & 100 \\
\hline $\begin{array}{l}\text { Assessment is Part of } \\
\text { Strategic Plan }\end{array}$ & 42 & 25.15 & 90 & 53.89 & 22 & 13.17 & 11 & 6.59 & 0 & 0.00 & 165 & 98.80 & 2 & 1.20 & 167 & 100 \\
\hline $\begin{array}{l}\text { Assessment is Part of } \\
\text { Internal Program } \\
\text { Review }\end{array}$ & 43 & 25.75 & 81 & 48.50 & 31 & 18.56 & 7 & 4.19 & 1 & 0.60 & 163 & 97.60 & 4 & 2.40 & 167 & 100 \\
\hline
\end{tabular}




\section{Principle 9. Through assessment, educators meet responsibilities to students and to the}

public. Assessment is a way that educators can indicate to students and to the public that they are doing achieving their mission and educating students. This area of questions included questions 43, 49, 57, 76 and 78. They were analyzed using means analysis to determine the extent Principle 9 was used in business schools. The mean response for Principle 9 was $3.49(S D=0.58)$. Only one institution disagreed that the quality of teaching was important on their campus and approximately $75 \%$ strongly agreed that it was. Over half $(59.28 \%)$ of units indicated that assessment results were not shared with the public, less than $15 \%$ agreed or strongly agreed. Almost half of the units also indicated that assessment results were not shared with the students and nearly $20 \%$ were neutral. Almost half (48.50) of the units did indicate that their outcomes are clearly communicated to learners; however, over one-third $(34.13 \%)$ were neutral on the subject. 
Table 50

Principle 9-Assessment Accountability and Distribution of Assessment Information

\begin{tabular}{|c|c|c|c|c|c|c|c|c|c|c|c|c|c|c|c|c|}
\hline & \multicolumn{2}{|c|}{$\begin{array}{l}\text { Strongly } \\
\text { Agree }\end{array}$} & \multicolumn{2}{|c|}{ Agree } & \multicolumn{2}{|c|}{ Neutral } & \multicolumn{2}{|c|}{ Disagree } & \multicolumn{2}{|c|}{$\begin{array}{l}\text { Strongly } \\
\text { Disagree }\end{array}$} & \multicolumn{2}{|c|}{ Total } & \multicolumn{2}{|c|}{$\begin{array}{l}\text { No } \\
\text { Response }\end{array}$} & \multicolumn{2}{|c|}{ Total } \\
\hline & $N$ & $\%$ & $N$ & $\%$ & $N$ & $\%$ & $N$ & $\%$ & $N$ & $\%$ & $N$ & $\%$ & $N$ & $\%$ & $N$ & $\%$ \\
\hline $\begin{array}{l}\text { Quality of Teaching } \\
\text { Importance }\end{array}$ & 126 & 75.45 & 37 & 22.16 & 3 & 1.80 & 1 & 0.60 & 0 & 0.00 & 167 & 100.00 & 0 & 0.00 & 167 & 100 \\
\hline $\begin{array}{l}\text { Assessment Goals are } \\
\text { Shared }\end{array}$ & 54 & 32.34 & 82 & 49.10 & 22 & 13.17 & 8 & 4.79 & 1 & 0.60 & 167 & 100.00 & 0 & 0.00 & 167 & 100 \\
\hline $\begin{array}{l}\text { Outcomes are Clearly } \\
\text { Communicated to } \\
\text { Learners }\end{array}$ & 23 & 13.77 & 58 & 34.73 & 57 & 34.13 & 24 & 14.37 & 1 & 0.60 & 163 & 97.60 & 4 & 2.40 & 167 & 100 \\
\hline $\begin{array}{l}\text { Assessment Results } \\
\text { are Reported to } \\
\text { Students }\end{array}$ & 5 & 2.99 & 42 & 25.15 & 33 & 19.76 & 63 & 37.72 & 18 & 10.78 & 161 & 96.41 & 6 & 3.59 & 167 & 100 \\
\hline $\begin{array}{l}\text { Assessment Results } \\
\text { are Shared with } \\
\text { Public }\end{array}$ & 4 & 2.40 & 20 & 11.98 & 39 & 23.35 & 65 & 38.92 & 34 & 20.36 & 162 & 97.01 & 5 & 2.99 & 167 & 100 \\
\hline
\end{tabular}




\section{Research Question 2}

To what degree do assessment activities impact the success of business schools?

As explained previously, eight questions in the last section of the survey (questions 85 through 92), related to the success of students, graduates, and the curriculum. These were analyzed using frequency and means analysis to answer Research Question 2. Then, correlations of the frequency of assessment practices by principle and perceived success of a business unit were conducted. There were 96 correlations total (see Table 6 in Chapter 3 for details). The variables for the correlation were Success and Principle. Mean responses to each of the eight success questions were correlated with mean responses to questions pertaining to each Principle. Because there were three parts to Principle 2, each was considered separately and then comprehensively. There were 12 total principle variables. Table 7, Matrix of Correlations, shows the 96 correlations and the questions included.

There were three questions that related to the success of enrolled undergraduate students. These responses had similar means (between .01 and .12 mean differences). Assessment's connection to the students' ability to secure internships had the lowest mean response of 2.81 . Low means indicate that there is little perceived assessment impact on student success (a value of $2=$ disagree and $3=$ neutral). Two questions were related to the graduates of programs. These questions sought to discover the impact assessment had on graduates' ability to obtain jobs and job performance. Although still low, the means for these two questions were higher than the perceived impact on students (obtain job mean $=3.02$, skills and job performance $=3.30$ ). The remaining three questions in this section focused on the unit impact of assessment. One queried the impact of assessment on curriculum updates $(M=4.01)$, one looked at the unit's ability to achieve or sustain accreditation $(M=4.31)$, and, finally, the quality and success of the unit 
$(M=3.98)$. These higher numbers indicate that assessment's impact is seen as having the most direct impact on the success of the unit rather than the student or graduate (see Table 51).

Table 51

Frequency and Means of Success Factor Responses

\begin{tabular}{|c|c|c|c|c|c|c|}
\hline & $N$ & Range & Min & $\operatorname{Max}$ & $M$ & $S D$ \\
\hline Passing Grades & 156 & 4 & 1 & 5 & 2.81 & 1.002 \\
\hline Secure Internships & 154 & 4 & 1 & 5 & 2.70 & 1.042 \\
\hline $\begin{array}{l}\text { Indicators: } \\
\text { Graduation Rates }\end{array}$ & 152 & 4 & 1 & 5 & 2.82 & .964 \\
\hline $\begin{array}{l}\text { Graduates Ability to } \\
\text { Obtain Job }\end{array}$ & 151 & 4 & 1 & 5 & 3.02 & 1.016 \\
\hline $\begin{array}{l}\text { Graduate Skills and } \\
\text { Job Performance }\end{array}$ & 153 & 4 & 1 & 5 & 3.30 & 1.001 \\
\hline Update Curriculum & 157 & 4 & 1 & 5 & 4.01 & .844 \\
\hline $\begin{array}{l}\text { Achieve/Sustain } \\
\text { Accreditation }\end{array}$ & 159 & 4 & 1 & 5 & 4.31 & .797 \\
\hline $\begin{array}{l}\text { Quality and Success } \\
\text { of Unit }\end{array}$ & 162 & 4 & 1 & 5 & 3.98 & .838 \\
\hline
\end{tabular}


The results of the research indicate a statistically significant positive correlation between good assessment practices and the success of the business unit (see Table 52). Of the success factors that were tested, those that had a direct relation to and involvement of students or graduates, all had positive correlations to all the principles that were tested (passing grades securing internships, graduation rates, graduates' abilities and job performance). Although the majority of the tests did have a resulting statistically significant correlation, those that were more closely related to the unit, updating curriculum and the quality and success of the unit, did not have a statistically significant correlation with all of the principles.

The most noted lack of correlation was with the direct and indirect measures. Indirect measures did not correlate with updating the curriculum, however, direct measures did show a significance. The quality and success of the unit did not correlate with either direct or indirect measures. Achieving or sustaining accreditation did not have a statistically significant correlation with direct measures, indirect measures, the overall Principle 2 and Principle 9. The remaining correlations were found to be statistically significant. Although indirect measures and job performance indicated a significant model, it was only significant at the .05 level. It is also worthy to note that Direct Measures and passing grades was the only other correlation that was not significant at the 0.01 level $(r=0.192, p(2$-tailed $)=.017, N=154)$. It is an interesting finding that the direct assessment of student learning does not have a significant linear relationship with passing grades. Accreditation achievement or sustainment was also only significant at the .05-level when correlated with Principle 6. The strongest correlations included those that involved the unit successes, which were the highest mean values in the success section. Updating the curriculum was found to have a level of correlation with Principle 3, 5, and 7 that exceeded .5 in each case. The highest correlation was .644 and was with Principle 5. This 
indicates the strongest linear relationship between assessment and unit success is the continuous process of assessment over time and the ability to modify and update curriculum. The quality and success of the unit also had a high correlation (>.5) with Principles 5 and 7, which indicates an increasing relationship between the success and quality of the business unit increases as the unit focuses on assessing issues that are important to them and that the assessment in the department is an ongoing process. The only other correlation that was significant at the 0.01 or 0.05 level and above 0.5 was Principle 4 and passing grades. It is very interesting that there was no significant relationship between direct and indirect assessments; however, the consideration of experiences did have a positive linear relationship with the student ability to earn passing grades. 
Table 52

Correlations of Success Factors and Assessment Principles

\begin{tabular}{|c|c|c|c|c|c|c|c|c|c|c|c|c|c|}
\hline & & 1 & $\begin{array}{l}\text { 2: Direct } \\
\text { Measures }\end{array}$ & $\begin{array}{l}\text { 2: Indirect } \\
\text { Measures }\end{array}$ & $\begin{array}{c}2: \\
\text { General }\end{array}$ & $\begin{array}{c}2: \\
\text { Overall } \\
\end{array}$ & 3 & 4 & 5 & 6 & 7 & 8 & 9 \\
\hline \multirow[t]{2}{*}{ Passing Grades } & $r$ & $.253^{* *}$ & $.192^{*}$ & $.232^{* *}$ & $.422^{* *}$ & $.333^{* *}$ & $.237^{* *}$ & $.512^{* *}$ & $.262^{* *}$ & $.329^{* *}$ & $.245^{* *}$ & $.304^{* *}$ & $.320^{* *}$ \\
\hline & $N$ & 155 & 154 & 155 & 156 & 156 & 156 & 156 & 156 & 156 & 156 & 156 & 156 \\
\hline \multirow[t]{2}{*}{ Secure Internships } & $r$ & $.298 * *$ & $.261 * *$ & $.245 * *$ & $.272 * *$ & $.330 * *$ & $.247 * *$ & $.353 * *$ & $.313 * *$ & $.254 * *$ & $.295 * *$ & $.285^{* *}$ & $.377 * *$ \\
\hline & $N$ & 153 & 152 & 153 & 154 & 154 & 154 & 154 & 154 & 154 & 154 & 154 & 154 \\
\hline \multirow[t]{2}{*}{ Graduation Rates } & $r$ & $.366^{* *}$ & $.233 * *$ & $.282 * *$ & $.355^{* *}$ & $.358 * *$ & $.347 * *$ & $.439 * *$ & $.332 * *$ & $.293 * *$ & $.407 * *$ & $.227 * *$ & $.395^{* *}$ \\
\hline & $N$ & 151 & 150 & 151 & 152 & 152 & 152 & 152 & 152 & 152 & 152 & 152 & 152 \\
\hline \multirow{2}{*}{$\begin{array}{l}\text { Graduates Ability to } \\
\text { Obtain Job }\end{array}$} & $r$ & $.275^{* *}$ & $.288 * *$ & $.236^{* *}$ & $.329 * *$ & $.354 * *$ & $.364 * *$ & $.385^{* *}$ & $.317 * *$ & $.345^{* *}$ & $.395 * *$ & $.306^{* *}$ & $.414 * *$ \\
\hline & $N$ & 150 & 149 & 150 & 151 & 151 & 151 & 151 & 151 & 151 & 151 & 151 & 151 \\
\hline \multirow{2}{*}{$\begin{array}{l}\text { Graduate Skills and } \\
\text { Job Performance }\end{array}$} & $r$ & $.266^{* *}$ & $.284 * *$ & $.193^{*}$ & $.377 * *$ & $.340 * *$ & $.415^{* *}$ & $.352 * *$ & $.447 * *$ & $.369 * *$ & $.462 * *$ & $.350 * *$ & $.417 * *$ \\
\hline & $N$ & 152 & 151 & 152 & 153 & 153 & 153 & 153 & 153 & 153 & 153 & 153 & 153 \\
\hline \multirow[t]{2}{*}{ Update Curriculum } & $r$ & $.328 * *$ & $.237 * *$ & .124 & $.374 * *$ & $.284 * *$ & $.535 * *$ & $.365 * *$ & $.644 * *$ & $.330 * *$ & $.621 * *$ & $.417 * *$ & $.384 * *$ \\
\hline & $N$ & 155 & 155 & 156 & 157 & 157 & 157 & 157 & 157 & 157 & 157 & 157 & 157 \\
\hline \multirow{2}{*}{$\begin{array}{l}\text { Achieve/Sustain } \\
\text { Accreditation }\end{array}$} & $r$ & $.227 * *$ & .077 & .031 & $.322 * *$ & .140 & $.437 * *$ & $.243 * *$ & $.432 * *$ & $.178 *$ & $.372 * *$ & $.205^{* *}$ & .122 \\
\hline & $N$ & 157 & 157 & 158 & 159 & 159 & 159 & 159 & 159 & 159 & 159 & 159 & 159 \\
\hline \multirow{2}{*}{$\begin{array}{l}\text { Quality and Success } \\
\text { of Unit }\end{array}$} & $r$ & $.315^{* *}$ & .154 & .153 & $.375^{* *}$ & $.257 * *$ & $.471^{* *}$ & $.319 * *$ & $.534 * *$ & $.336 * *$ & $.509 * *$ & $.411^{* *}$ & $.375^{* *}$ \\
\hline & $N$ & 160 & 160 & 161 & 162 & 162 & 162 & 162 & 162 & 162 & 162 & 162 & 162 \\
\hline
\end{tabular}

** $\mathrm{p}<0.01$ (2-tailed). * $\mathrm{p}<0.05$ (2-tailed). 


\section{Research Question 3}

Is there a significant difference in outcomes assessment practices utilized by business schools according to their accrediting body (by IACBE, ACBSP, and AACSB)?

Multivariate analysis of variance (MANOVA), frequency counts, and means were used to test Research Question 3. For the MANOVA analysis, the categorical independent variable, the accreditation body, was tested to see if there was a statistically different response to the dependent variables, the survey questions, by looking at the means of the questions broken down by independent variable (AACSB, ACBSP, and IACBE).

As explained in Table 7 in Chapter 3, first, one overall principle MANOVA was conducted as an initial test. The results of the overall multivariate test indicated a significant model $(F(22,292)=1.657, p=.034$, Wilks' $\Lambda=.790)$. An observed power of 0.967 indicated a low potential for a type II error. In addition, using a significance of .001, due to the different sizes of the groupings, there was no significant difference in the observed covariance matrices of the dependent variables.

After finding significance, 15 MANOVAs were conducted with item responses grouped together by principle focus, commitments, and success. Each principle required one MANOVA with the exception of Principle 2, which was broken into three data sets for the MANOVAs. The first Principle 2 MANOVA was for the overall Principle. The two remaining computations were for direct assessment measures and for indirect assessment measures. In addition to the Principle questions, the assessment and accreditation commitments, revision influences, and the success factors were evaluated using the multivariate analysis. 
Upon closer inspection, of the post-hoc test, significant differences in mean by group were found for Principles 1 and 2; however, no significant difference by group was identified for the 7 remaining Principles.

In the overall MANOVA (for Principles 1-9), Principle 3 did not yield a significant difference at the .05 level, however, it was not homogeneous (Tukey's HSD) which may indicate trending toward significance (see Table 53). It is difficult to predict this trend, however, due to the Type III error not retaining the Type I error integrity (caused by the unequal sample size and the use of a harmonic mean sample size). 
Table 53

Tukey’s HSD Test Homogeneous Subsets by Significantly Different Principle

\begin{tabular}{|c|c|c|c|c|}
\hline & Accreditation & $N$ & Subset 1 & Subset 2 \\
\hline \multicolumn{5}{|c|}{ Principle 1 Assessment Begins with Education Values } \\
\hline \multicolumn{5}{|c|}{$M S E=.545$} \\
\hline & AACSB & 77 & 4.2208 & \\
\hline & ACBSP & 47 & 4.3511 & 4.3511 \\
\hline & IACBE & 35 & & 4.5857 \\
\hline$P$ & & & .665 & .269 \\
\hline \multicolumn{5}{|c|}{ Principle 2 Direct Measures } \\
\hline \multicolumn{5}{|c|}{$M S E=.690$} \\
\hline & $\mathrm{AACSB}$ & 77 & 3.2006 & \\
\hline & ACBSP & 47 & 3.6009 & 3.6009 \\
\hline & IACBE & 35 & & 3.8060 \\
\hline$P$ & & & .052 & .451 \\
\hline \multicolumn{5}{|c|}{ Principle 2 Indirect Measures } \\
\hline \multicolumn{5}{|c|}{$M S E=.815$} \\
\hline & ACBSP & 47 & 2.9560 & \\
\hline & AACSB & 77 & 2.9961 & 2.9961 \\
\hline & IACBE & 35 & & 3.4116 \\
\hline$P$ & & & .974 & .066 \\
\hline
\end{tabular}

Principle 3 Programs have Clearly Stated Purpose

$M S E=.389$

\begin{tabular}{lccc} 
ACBSP & 47 & 3.9191 & \\
AACSB & 77 & 4.0234 & 4.0234 \\
IACBE & 35 & & 4.2457 \\
& & .694 & .193 \\
\hline
\end{tabular}

Note. Based on Type III Sum of Squares. Uses Harmonic Mean Sample Size $=47.744$. $\mathrm{p}<.05$.

The results of the individual principle MANOVAs indicated that there was a significant difference at the .05-level in Principle 1. (Wilks' $\Lambda=.930, F=2.784, d f=(4,302), p=.027, \eta^{2}=$ 
.036). Due to the significant model, the two questions were reviewed for structural differences among the two variables. The means indicate that the mission of the institution is somewhat clear (value of 4) in the stated outcomes and assessment activities of the institution. The respondents indicated that the unit mission was between somewhat clear (4) and very clear (5). An examination of the individual means indicates that the connection of assessment to the unit mission by all three accreditation groups was higher than the institution connection and the standard deviation was not as great for the units (see Table 54).

Table 54

Means of Principle 1 by Accreditation Agency

\begin{tabular}{lcccc}
\hline & Accreditation & $M$ & $S D$ & $N$ \\
\hline $\begin{array}{l}\text { Item 7 Institution Mission } \\
\text { Clarity in Outcomes and }\end{array}$ & AACSB & 3.99 & .959 & 76 \\
Assessments & ACBSP & 4.37 & .952 & 43 \\
& IACBE & 4.53 & .654 & 36 \\
& Total & 4.22 & .921 & 155 \\
$\begin{array}{l}\text { Item 17 Unit Mission Clarity } \\
\text { in Outcomes and }\end{array}$ & AACSB & 4.41 & .786 & 76 \\
Assessments & ACBSP & 4.49 & .768 & 43 \\
& IACBE & 4.67 & .478 & 36 \\
& Total & 4.49 & .724 & 155 \\
\hline
\end{tabular}

The univariate analysis shows the significant difference in the clarity of institution mission in assessments and outcomes (see Table 55). This difference was found for IACBE and $\operatorname{AACSB}\left(M_{\text {diff }}=0.541, S D=.181, p=.010\right)$. The means for AACSB institutions was at the level of somewhat clear $(M=3.99, S D=.959, N=76)$, while the mean for IACBE was significantly higher $(M=4.53, S D=.654, N=36)$. 
Table 55

Principle 1 Mission Clarity in Assessments and Outcomes Univariate Test Results

\begin{tabular}{llcccccc}
\hline Dependent Variable & & $S S$ & $d f$ & $M S$ & $F$ & $p$ & $\eta^{2}$ \\
\hline $\begin{array}{l}\text { Institution Mission } \\
\text { Clarity }\end{array}$ & Contrast & 8.536 & 2 & 4.268 & 5.317 & $.006^{*}$ & .065 \\
& Error & 122.006 & 152 & .083 & & & \\
Unit Mission Clarity & Contrast & 1.636 & 2 & .818 & 1.572 & .211 & .020 \\
& Error & 79.099 & 152 & .520 & & & \\
\hline
\end{tabular}

Note. The F tests the effect of Accreditation. This test is based on the linearly independent pairwise comparisons among the estimated marginal means.

Computed using alpha $=.05$

Specifically, the results indicated a homogenous group for AACSB and ACBSP, and ACBSP and IACBE; however, for AACSB and IACBE Tukey's Honestly Significant Difference Test showed a significant difference at the 0.05 level (see Table 56). 
Table 56

Tukey's HSD Test of Multiple Comparisons Principle 1

\begin{tabular}{|c|c|c|c|c|c|c|c|}
\hline \multirow[t]{2}{*}{ Dependent Variable } & \multirow[t]{2}{*}{ Accreditation } & \multirow[t]{2}{*}{ Accreditation } & \multirow[t]{2}{*}{$M_{\text {diff }}$} & \multirow[t]{2}{*}{$S E$} & \multirow[t]{2}{*}{$p$} & \multicolumn{2}{|c|}{$95 \%$ Confidence Interva } \\
\hline & & & & & & $\begin{array}{l}\text { Lower } \\
\text { Bound }\end{array}$ & $\begin{array}{l}\text { Upper } \\
\text { Bound } \\
\end{array}$ \\
\hline \multirow{7}{*}{$\begin{array}{l}\text { Institution Mission } \\
\text { Clarity in Outcomes and } \\
\text { Assessments }\end{array}$} & AACSB & ACBSP & & & & & \\
\hline & & &.- .39 & .171 & .066 & -.79 & .02 \\
\hline & & IACBE & $-.54 *$ & .181 & $.009 *$ & -.97 & -.11 \\
\hline & ACBSP & AACSB & .39 & .171 & .066 & -.02 & .79 \\
\hline & & IACBE & -.16 & .202 & .722 & -.63 & .32 \\
\hline & IACBE & AACSB & $.54^{*}$ & .181 & $.009 *$ & .11 & .97 \\
\hline & & ACBSP & .16 & .202 & .772 & -.32 & .63 \\
\hline \multirow{6}{*}{$\begin{array}{l}\text { Unit Mission Clarity in } \\
\text { Outcomes and } \\
\text { Assessments }\end{array}$} & AACSB & ACBSP & -.08 & .139 & .829 & -.41 & .25 \\
\hline & & IACBE & -.26 & .146 & .182 & -.60 & .09 \\
\hline & ACBSP & AACSB & .08 & .138 & .829 & -.25 & .41 \\
\hline & & IACBE & -.18 & .163 & .519 & -.56 & .21 \\
\hline & IACBE & AACSB & .26 & .146 & .182 & -.09 & .60 \\
\hline & & ACBSP & .18 & .163 & .519 & -.21 & .56 \\
\hline
\end{tabular}


Principle 2 was analyzed by the three components, Direct Measures, Indirect Measures, and general principle questions. The initial analysis contained the final category option of "other" for the direct and indirect assessment measures. When reviewed, the results were found to violate Box's test at the .001 level and also had a very low number of total cases which made the groupings extremely small and extremely susceptible to deviation by single cases. The MANOVA was revised to exclude the "other" option and the results do not violate the required assumptions of the MANOVA (although the groups are not equal in size Box's Test at the .001 level was not significant). After removing the "other" responses, the use of Direct Measures (Wilks' $\left.\Lambda=.701, F=1.785, d f=(22,202), p=.020, \eta^{2}=.163\right)$ and Indirect Measures (Wilks' $\Lambda$ $\left.=.734, F=2.299, d f=(16,220), p=.004, \eta^{2}=.143\right)$ were found to be significantly different by accreditation agency.

The results of the univariate tests of each direct assessment by accreditation agency indicated that in every assessment except Commercial Exams, the mean IACBE score was higher than the other two agencies (see Table 57). In most instances, the mean AACSB score indicated the least use of the instrument. Only in written problems did AACSB indicate a higher use of the assessment than ACBSP (by .01). Oral exams and portfolios were the two lowest direct assessment instruments, with total means of 2.07 and 2.11 respectively which indicated an occasional use. Written exams were the most frequently used direct assessment, and the total mean use of written exams was 3.93, which means they are used often.

Tukey's HSD test showed AACSB and IACBE to have significant differences in written exam practices, portfolios, and internship/practicum evaluations. AACSB and ACBSP had differences in the use of written exams, commercial exams, and internship/practicum evaluations 
(see Error! Not a valid bookmark self-reference.

). In all significant instances, AACSB accredited business unites reported using the assessment less frequently than either IACBE, ACBSP, or both. The largest mean difference was the use of commercial exams between AACSB and ACBSP $\left(M_{\text {diff }}=1.14, p=.001\right)$.

Table 57

Means of Direct Assessments by Accreditation Agency

\begin{tabular}{|c|c|c|c|c|}
\hline & Accreditation & $M$ & $S D$ & $N$ \\
\hline \multirow[t]{4}{*}{ Written Exams } & AACSB & 3.58 & 1.343 & 55 \\
\hline & ACBSP & 4.20 & 1.158 & 35 \\
\hline & IACBE & 4.33 & .637 & 24 \\
\hline & Total & 3.93 & 1.210 & 114 \\
\hline \multirow[t]{4}{*}{ Quizzes } & AACSB & 3.18 & 1.553 & 55 \\
\hline & ACBSP & 3.46 & 1.462 & 35 \\
\hline & IACBE & 3.75 & 1.073 & 24 \\
\hline & Total & 3.39 & 1.442 & 114 \\
\hline \multirow[t]{4}{*}{ Commercial Exams } & AACSB & 2.89 & 1.511 & 55 \\
\hline & ACBSP & 4.03 & 1.361 & 35 \\
\hline & IACBE & 3.42 & 1.501 & 24 \\
\hline & Total & 3.35 & 1.534 & 114 \\
\hline \multirow[t]{4}{*}{ Oral Exams } & AACSB & 1.95 & 1.096 & 55 \\
\hline & ACBSP & 2.17 & 1.382 & 35 \\
\hline & IACBE & 2.21 & 1.021 & 24 \\
\hline & Total & 2.07 & 1.173 & 114 \\
\hline \multirow[t]{4}{*}{ Written Problems } & AACSB & 3.27 & 1.062 & 55 \\
\hline & ACBSP & 3.26 & 1.379 & 35 \\
\hline & IACBE & 3.63 & 1.013 & 24 \\
\hline & Total & 3.34 & 1.158 & 114 \\
\hline Thesis or Term Papers & AACSB & 3.00 & 1.440 & 55 \\
\hline
\end{tabular}




\begin{tabular}{cccc} 
ACBSP & 3.43 & 1.290 & 35 \\
IACBE & 3.71 & .999 & 24 \\
Total & 3.28 & 1.334 & 114 \\
\hline
\end{tabular}


Table 57

Means of Direct Assessments by Accreditation Agency

\begin{tabular}{|c|c|c|c|c|}
\hline & Accreditation & $M$ & $S D$ & $N$ \\
\hline \multirow[t]{4}{*}{ Projects } & AACSB & 3.55 & 1.199 & 55 \\
\hline & ACBSP & 3.83 & 1.317 & 35 \\
\hline & IACBE & 3.92 & .717 & 24 \\
\hline & Total & 3.71 & 1.158 & 114 \\
\hline \multirow[t]{4}{*}{$\begin{array}{l}\text { Case Studies and } \\
\text { Simulations }\end{array}$} & AACSB & 3.40 & 1.211 & 55 \\
\hline & ACBSP & 3.71 & 1.296 & 35 \\
\hline & IACBE & 3.96 & .955 & 24 \\
\hline & Total & 3.61 & 1.201 & 114 \\
\hline \multirow[t]{4}{*}{ Presentations } & AACSB & 3.44 & 1.259 & 55 \\
\hline & ACBSP & 3.71 & 1.250 & 35 \\
\hline & IACBE & 3.79 & 1.103 & 24 \\
\hline & Total & 3.60 & 1.225 & 114 \\
\hline \multirow[t]{4}{*}{ Portfolios } & AACSB & 1.85 & 1.008 & 55 \\
\hline & ACBSP & 2.14 & 1.240 & 35 \\
\hline & IACBE & 2.63 & 1.245 & 24 \\
\hline & Total & 2.11 & 1.163 & 114 \\
\hline \multirow[t]{4}{*}{$\begin{array}{l}\text { Internship/Practicum } \\
\text { Evaluations }\end{array}$} & AACSB & 2.16 & 1.385 & 55 \\
\hline & ACBSP & 3.26 & 1.482 & 35 \\
\hline & IACBE & 3.58 & 1.018 & 24 \\
\hline & Total & 2.80 & 1.477 & 114 \\
\hline
\end{tabular}


Table 58

Principle 2 Direct Assessment Univariate Test Results

\begin{tabular}{|c|c|c|c|c|c|c|c|}
\hline Dependent Variable & & $S S$ & $d f$ & $M S$ & $F$ & $p$ & $\eta^{2}$ \\
\hline \multirow[t]{2}{*}{ Written Exams } & Contrast & 13.123 & 2 & 6.562 & 4.782 & $.010 *$ & .079 \\
\hline & Error & 152.315 & 111 & 1.372 & & & \\
\hline \multirow[t]{2}{*}{ Quizzes } & Contrast & 5.650 & 2 & 2.825 & 1.367 & .259 & .024 \\
\hline & Error & 229.368 & 111 & 2.066 & & & \\
\hline \multirow[t]{2}{*}{ Commercial Exams } & Contrast & 27.815 & 2 & 13.907 & 6.482 & $.002 *$ & .105 \\
\hline & Error & 238.150 & 111 & 2.145 & & & \\
\hline \multirow[t]{2}{*}{ Oral Exams } & Contrast & 1.672 & 2 & .836 & .604 & .549 & .011 \\
\hline & Error & 153.766 & 111 & 1.385 & & & \\
\hline \multirow[t]{2}{*}{ Written Problems } & Contrast & 2.438 & 2 & 1.219 & .907 & .407 & .016 \\
\hline & Error & 149.220 & 111 & 1.344 & & & \\
\hline \multirow[t]{2}{*}{$\begin{array}{l}\text { Thesis or Term } \\
\text { Papers }\end{array}$} & Contrast & 9.488 & 2 & 4.744 & 2.749 & .068 & .047 \\
\hline & Error & 191.530 & 111 & 1.725 & & & \\
\hline \multirow[t]{2}{*}{ Projects } & Contrast & 3.006 & 2 & 1.503 & 1.124 & .329 & .020 \\
\hline & Error & 148.441 & 111 & 1.337 & & & \\
\hline \multirow[t]{2}{*}{$\begin{array}{l}\text { Case Studies and } \\
\text { Simulations }\end{array}$} & Contrast & 5.716 & 2 & 2.858 & 2.017 & .138 & .035 \\
\hline & Error & 157.301 & 111 & 1.417 & & & \\
\hline \multirow[t]{2}{*}{ Presentations } & Contrast & 2.810 & 2 & 1.405 & .936 & .395 & .017 \\
\hline & Error & 166.628 & 111 & 1.501 & & & \\
\hline \multirow[t]{2}{*}{ Portfolios } & Contrast & 9.990 & 2 & 4.995 & 3.884 & $.023 *$ & .065 \\
\hline & Error & 142.747 & 111 & 1.286 & & & \\
\hline \multirow[t]{2}{*}{$\begin{array}{l}\text { Internship/Practicum } \\
\text { Evaluations }\end{array}$} & Contrast & 44.313 & 2 & 22.157 & 12.172 & $.000 *$ & .180 \\
\hline & Error & 202.046 & 111 & 1.820 & & & \\
\hline
\end{tabular}

Note. The F tests the effect of Accreditation. This test is based on the linearly independent pairwise comparisons among the estimated marginal means.

Computed using alpha $=.05$ 
Error! Not a valid bookmark self-reference.

\begin{tabular}{lcccccccc}
\hline \multirow{2}{*}{ Dependent Variable } & \multirow{2}{*}{ Accreditation } & Accreditation & $M_{\text {diff }}$ & $S E$ & $P$ & \multicolumn{2}{c}{$95 \%$ Confidence Interval } \\
\cline { 6 - 9 } & & & & & & Lower Bound & Upper Bound \\
\hline \multirow{2}{*}{ Written Exams } & \multirow{2}{*}{ AACSB } & ACBSP & $-.62^{*}$ & .253 & $.043^{*}$ & -1.22 & -.02 \\
& & IACBE & $-.75^{*}$ & .287 & $.027^{*}$ & -1.43 & -.07 \\
& \multirow{4}{*}{ ACBSP } & AACSB & $.62^{*}$ & .253 & $.043^{*}$ & .02 & 1.22 \\
& IACBE & IACBE & -.13 & .310 & .903 & -.87 & .60 \\
& AACSB & $.75^{*}$ & .287 & $.027^{*}$ & .07 & 1.43 \\
& AACSB & ACBSP & .13 & .310 & .903 & -.60 & .87 \\
& ACBizzes & ACBSP & -.28 & .311 & .650 & -1.01 & .46 \\
& IACBE & -.57 & .352 & .243 & -1.40 & .27 \\
& IACBE & AACSB & .28 & .311 & .650 & -.46 & 1.01 \\
& & IACBE & -.29 & .381 & .723 & -1.20 & .61 \\
& AACSB & .57 & .352 & .243 & -.27 & 1.40 \\
& & ACBSP & .29 & .381 & .723 & -.61 & 1.20 \\
\hline
\end{tabular}


Table 59 Continued

Tukey’s HSD Test of Multiple Comparisons Principle 2a Direct Assessments

\begin{tabular}{|c|c|c|c|c|c|c|c|}
\hline \multirow[t]{2}{*}{ Dependent Variable } & \multirow[t]{2}{*}{ Accreditation } & \multirow[t]{2}{*}{ Accreditation } & \multirow[t]{2}{*}{$M_{\text {diff }}$} & \multirow[t]{2}{*}{$S E$} & \multirow[t]{2}{*}{$p$} & \multicolumn{2}{|c|}{ 95\% Confidence Interval } \\
\hline & & & & & & Lower Bound & Upper Bound \\
\hline \multirow[t]{6}{*}{ Commercial Exams } & AACSB & ACBSP & $-1.14 *$ & .317 & $.001 *$ & -1.89 & -.39 \\
\hline & & IACBE & -.53 & .358 & .311 & -1.38 & .33 \\
\hline & ACBSP & AACSB & $1.14^{*}$ & .317 & $.001 *$ & .39 & 1.89 \\
\hline & & IACBE & .61 & .388 & .260 & -.31 & 1.53 \\
\hline & IACBE & AACSB & .53 & .358 & .311 & -.33 & 1.38 \\
\hline & & ACBSP & -.61 & .388 & .260 & -1.53 & .31 \\
\hline \multirow[t]{6}{*}{ Oral Exams } & AACSB & ACBSP & -.23 & .254 & .649 & -.83 & .38 \\
\hline & & IACBE & -.26 & .288 & .633 & -.95 & .42 \\
\hline & ACBSP & AACSB & .23 & .254 & .649 & -.38 & .83 \\
\hline & & IACBE & -.04 & .312 & .992 & -.78 & .70 \\
\hline & IACBE & AACSB & .26 & .288 & .633 & -.42 & .95 \\
\hline & & ACBSP & .04 & .312 & .992 & -.70 & .78 \\
\hline \multirow[t]{6}{*}{ Written Problems } & AACSB & ACBSP & .02 & .251 & .998 & -.58 & .61 \\
\hline & & IACBE & -.35 & .284 & .431 & -1.03 & .32 \\
\hline & ACBSP & AACSB & -.02 & .251 & .998 & -.61 & .58 \\
\hline & & IACBE & -.37 & .307 & .457 & -1.10 & .36 \\
\hline & IACBE & AACSB & .35 & .284 & .431 & -.32 & 1.03 \\
\hline & & ACBSP & .37 & .307 & .457 & -.36 & 1.10 \\
\hline
\end{tabular}


Table 59 Continued

Tukey's HSD Test of Multiple Comparisons Principle 2a Direct Assessments

\begin{tabular}{|c|c|c|c|c|c|c|c|}
\hline \multirow[t]{2}{*}{ Dependent Variable } & \multirow[t]{2}{*}{ Accreditation } & \multirow[t]{2}{*}{ Accreditation } & \multirow[t]{2}{*}{$M_{\text {diff }}$} & \multirow[t]{2}{*}{$S E$} & \multirow[t]{2}{*}{$p$} & \multicolumn{2}{|c|}{$95 \%$ Confidence Interval } \\
\hline & & & & & & Lower Bound & Upper Bound \\
\hline \multirow[t]{6}{*}{$\begin{array}{l}\text { Thesis or Term } \\
\text { Papers }\end{array}$} & AACSB & ACBSP & -.43 & .284 & .291 & -1.10 & .25 \\
\hline & & IACBE & -.71 & .321 & .075 & -1.47 & .06 \\
\hline & ACBSP & AACSB & .43 & .284 & .291 & -.25 & 1.10 \\
\hline & & IACBE & -.28 & .348 & .702 & -1.11 & .55 \\
\hline & IACBE & AACSB & .71 & .321 & .075 & -.06 & 1.47 \\
\hline & & ACBSP & .28 & .348 & .702 & -.55 & 1.11 \\
\hline \multirow[t]{6}{*}{ Projects } & $\mathrm{AACSB}$ & ACBSP & -.28 & .250 & .496 & -.88 & .31 \\
\hline & & IACBE & -.37 & .283 & .391 & -1.04 & .30 \\
\hline & ACBSP & AACSB & .28 & .250 & .496 & -.31 & .88 \\
\hline & & IACBE & -.09 & .306 & .955 & -.82 & .64 \\
\hline & IACBE & AACSB & .37 & .283 & .391 & -.30 & 1.04 \\
\hline & & ACBSP & .09 & .306 & .955 & -.64 & .82 \\
\hline
\end{tabular}


Table 59 Continued

Tukey's HSD Test of Multiple Comparisons Principle 2a Direct Assessments

\begin{tabular}{|c|c|c|c|c|c|c|c|}
\hline \multirow[t]{2}{*}{ Dependent Variable } & \multirow[t]{2}{*}{ Accreditation } & \multirow[t]{2}{*}{ Accreditation } & \multirow[t]{2}{*}{$M_{\text {diff }}$} & \multirow[t]{2}{*}{$S E$} & \multirow[t]{2}{*}{$p$} & \multicolumn{2}{|c|}{$95 \%$ Confidence Interval } \\
\hline & & & & & & Lower Bound & Upper Bound \\
\hline \multirow[t]{6}{*}{$\begin{array}{l}\text { Case Studies and } \\
\text { Simulations }\end{array}$} & AACSB & ACBSP & -.31 & .257 & .443 & -.93 & .30 \\
\hline & & $\mathrm{IACBE}$ & -.56 & .291 & .139 & -1.25 & .13 \\
\hline & ACBSP & AACSB & .31 & .257 & .443 & -.30 & .93 \\
\hline & & IACBE & -.24 & .315 & .720 & -.99 & .51 \\
\hline & IACBE & AACSB & .56 & .291 & .139 & -.13 & 1.25 \\
\hline & & ACBSP & .24 & .315 & .720 & -.51 & .99 \\
\hline \multirow[t]{6}{*}{ Presentations } & $\mathrm{AACSB}$ & ACBSP & -.28 & .265 & .548 & -.91 & .35 \\
\hline & & $\mathrm{IACBE}$ & -.36 & .300 & .464 & -1.07 & .36 \\
\hline & ACBSP & AACSB & .28 & .265 & .548 & -.35 & .91 \\
\hline & & IACBE & -.08 & .325 & .969 & -.85 & .69 \\
\hline & IACBE & AACSB & .36 & .300 & .464 & -.36 & 1.07 \\
\hline & & ACBSP & .08 & .325 & .969 & -.69 & .85 \\
\hline
\end{tabular}


Table 59 Continued

Tukey's HSD Test of Multiple Comparisons Principle 2a Direct Assessments

\begin{tabular}{|c|c|c|c|c|c|c|c|}
\hline \multirow[t]{2}{*}{ Dependent Variable } & \multirow[t]{2}{*}{ Accreditation } & \multirow[t]{2}{*}{ Accreditation } & \multirow[t]{2}{*}{$M_{\text {diff }}$} & \multirow[t]{2}{*}{$S E$} & \multirow[t]{2}{*}{$p$} & \multicolumn{2}{|c|}{$95 \%$ Confidence Interval } \\
\hline & & & & & & Lower Bound & Upper Bound \\
\hline \multirow[t]{6}{*}{ Portfolios } & AACSB & ACBSP & -.29 & .245 & .470 & -.87 & .29 \\
\hline & & IACBE & $-.77 *$ & .277 & $.018 *$ & -1.43 & -.11 \\
\hline & ACBSP & AACSB & .29 & .245 & .470 & -.29 & .87 \\
\hline & & IACBE & -.48 & .301 & .248 & -1.20 & .23 \\
\hline & IACBE & AACSB & $.77 *$ & .277 & $.018 *$ & .11 & 1.43 \\
\hline & & ACBSP & .48 & .301 & .248 & -.23 & 1.20 \\
\hline \multirow[t]{6}{*}{$\begin{array}{l}\text { Internship/Practicum } \\
\text { Evaluations }\end{array}$} & AACSB & ACBSP & $-1.09 *$ & .292 & $.001 *$ & -1.79 & -.40 \\
\hline & & $\mathrm{IACBE}$ & $-1.42 *$ & .330 & $.000 *$ & -2.20 & -.64 \\
\hline & ACBSP & AACSB & $1.09 *$ & .292 & $.001 *$ & .40 & 1.79 \\
\hline & & IACBE & -.33 & .358 & .634 & -1.18 & .52 \\
\hline & IACBE & AACSB & $1.42 *$ & .330 & $.000 *$ & .64 & 2.20 \\
\hline & & ACBSP & .33 & .358 & .634 & -.52 & 1.18 \\
\hline
\end{tabular}

Based on observed means.

* The mean difference is significant at the .05 level. 
A review of the univariate analysis (see Table 61), indicated the differences in indirect measures between subject pair-wise significant differences were in the use of reflection/journals, entrance interviews, student satisfaction surveys, and course evaluations. The student satisfaction survey and course evaluations are barely significant at a .05 level. When the indirect assessments were reviewed for multivariate effect, Tukey's HSD test found significant differences in reflections/journals, entrance interviews, and student satisfaction surveys (see Table 61). IACBE accredited units reported using reflections or journals significantly more frequently than AACSB accredited units. IACBS accredited units also reported using entrance interviews and student satisfaction surveys at a statistically significant level more often compared to ACBSP accredited units. Course evaluations were not found to have a significant multivariate effect by agency grouping and Tukey's test resulted in a harmonious grouping. The total mean was 3.96 with a standard deviation of 1.312 and the range of agency means from 3.67 to 4.32 (see Table 60). Entrance Interviews were the least used indirect assessment (total mean $=1.53, \mathrm{SD}=.970$ ) and reflections/journals also had a mean below 2. Course evaluations were the most common indirect assessment followed by student satisfaction surveys. Alumni surveys were the only other indirect assessment with a total mean above 3 .

Table 59

Means of Indirect Assessments by Accreditation Agency

\begin{tabular}{lcccc}
\hline & Accreditation & $M$ & $S D$ & $N$ \\
\hline \multirow{2}{*}{ Reflections or Journals } & AACSB & 1.69 & .992 & 61 \\
& ACBSP & 2.09 & 1.190 & 34 \\
& IACBE & 2.56 & 1.474 & 25 \\
& Total & 1.98 & 1.202 & 120 \\
\hline
\end{tabular}


Table 60 Continued

Means of Indirect Assessments by Accreditation Agency

\begin{tabular}{|c|c|c|c|c|}
\hline & Accreditation & $M$ & $S D$ & $N$ \\
\hline \multirow[t]{4}{*}{ Entrance Interviews } & AACSB & 1.52 & 1.010 & 61 \\
\hline & ACBSP & 1.26 & .666 & 34 \\
\hline & IACBE & 1.92 & 1.115 & 25 \\
\hline & Total & 1.53 & .970 & 120 \\
\hline \multirow[t]{4}{*}{ Exit Interviews } & $\mathrm{AACSB}$ & 3.10 & 1.524 & 61 \\
\hline & ACBSP & 2.50 & 1.600 & 34 \\
\hline & IACBE & 2.76 & 1.300 & 25 \\
\hline & Total & 2.86 & 1.514 & 120 \\
\hline \multirow[t]{4}{*}{ Focus Groups } & $\mathrm{AACSB}$ & 2.33 & 1.287 & 61 \\
\hline & ACBSP & 1.79 & .978 & 34 \\
\hline & IACBE & 2.40 & 1.258 & 25 \\
\hline & Total & 2.19 & 1.218 & 120 \\
\hline \multirow[t]{4}{*}{ Employer Surveys } & AACSB & 3.03 & 1.183 & 61 \\
\hline & ACBSP & 2.74 & 1.286 & 34 \\
\hline & IACBE & 2.88 & 1.130 & 25 \\
\hline & Total & 2.92 & 1.199 & 120 \\
\hline \multirow[t]{4}{*}{$\begin{array}{l}\text { Student Satisfaction } \\
\text { Surveys }\end{array}$} & AACSB & 3.75 & 1.312 & 61 \\
\hline & $\mathrm{ACBSP}$ & 3.44 & 1.541 & 34 \\
\hline & IACBE & 4.28 & .678 & 25 \\
\hline & Total & 3.78 & 1.306 & 120 \\
\hline \multirow[t]{4}{*}{ Alumni Surveys } & AACSB & 3.21 & 1.213 & 61 \\
\hline & ACBSP & 3.09 & 1.311 & 34 \\
\hline & IACBE & 3.52 & 1.122 & 25 \\
\hline & Total & 3.24 & 1.223 & 120 \\
\hline \multirow[t]{4}{*}{ Course Evaluations } & AACSB & 3.67 & 1.446 & 61 \\
\hline & ACBSP & 4.21 & 1.175 & 34 \\
\hline & IACBE & 4.32 & .988 & 25 \\
\hline & Total & 3.96 & 1.312 & 120 \\
\hline
\end{tabular}


Table 60

Principle 2 Indirect Assessment Univariate Test Results

\begin{tabular}{|c|c|c|c|c|c|c|c|}
\hline Dependent Variable & & $S S$ & $d f$ & $M S$ & $F$ & $p$ & $\eta^{2}$ \\
\hline \multirow[t]{2}{*}{ Reflections or Journals } & Contrast & 13.989 & 2 & 6.995 & 5.180 & $.007 *$ & .081 \\
\hline & Error & 157.977 & 117 & 1.350 & & & \\
\hline \multirow[t]{2}{*}{ Entrance Interviews } & Contrast & 6.196 & 2 & 3.098 & 3.430 & $.036 *$ & .055 \\
\hline & Error & 105.671 & 117 & .903 & & & \\
\hline \multirow[t]{2}{*}{ Exit Interviews } & Contrast & 8.122 & 2 & 4.061 & 1.797 & .170 & .030 \\
\hline & Error & 264.470 & 117 & 2.260 & & & \\
\hline \multirow[t]{2}{*}{ Focus Groups } & Contrast & 7.590 & 2 & 3.795 & 2.627 & .077 & .043 \\
\hline & Error & 169.001 & 117 & 1.444 & & & \\
\hline \multirow[t]{2}{*}{ Employer Surveys } & Contrast & 1.975 & 2 & .987 & .683 & .507 & .012 \\
\hline & Error & 169.192 & 117 & 1.446 & & & \\
\hline \multirow[t]{2}{*}{$\begin{array}{l}\text { Student Satisfaction } \\
\text { Surveys }\end{array}$} & Contrast & 10.191 & 2 & 5.096 & 3.093 & $.049 *$ & .050 \\
\hline & Error & 192.734 & 117 & 1.647 & & & \\
\hline \multirow[t]{2}{*}{ Alumni Surveys } & Contrast & 2.787 & 2 & 1.393 & .931 & .397 & .016 \\
\hline & Error & 175.205 & 117 & 1.497 & & & \\
\hline \multirow[t]{2}{*}{ Course Evaluations } & Contrast & 10.350 & 2 & 5.175 & 3.114 & $.048 *$ & .051 \\
\hline & Error & 194.441 & 117 & 1.662 & & & \\
\hline
\end{tabular}

Note. The F tests the effect of Accreditation. This test is based on the linearly independent pairwise comparisons among the estimated marginal means.

Computed using alpha $=.05$ 
Table 61

Tukey's HSD Test of Multiple Comparisons Principle $2 b$

\begin{tabular}{|c|c|c|c|c|c|c|c|}
\hline \multirow[t]{2}{*}{ Dependent Variable } & \multirow[t]{2}{*}{ Accreditation } & \multirow[t]{2}{*}{ Accreditation } & \multirow[t]{2}{*}{$M_{\text {diff }}$} & \multirow[t]{2}{*}{$S E$} & \multirow[t]{2}{*}{$P$} & \multicolumn{2}{|c|}{ 95\% Confidence Interval } \\
\hline & & & & & & Lower Bound & Upper Bound \\
\hline \multirow[t]{6}{*}{ Reflections or Journals } & AACSB & ACBSP & -.40 & .249 & .247 & -.99 & .19 \\
\hline & & IACBE & $-.87 *$ & .276 & $.006 *$ & -1.53 & -.22 \\
\hline & ACBSP & AACSB & .40 & .249 & .247 & -.19 & .99 \\
\hline & & IACBE & -.47 & .306 & .276 & -1.20 & .25 \\
\hline & IACBE & AACSB & $.87 *$ & .276 & $.006^{*}$ & .22 & 1.53 \\
\hline & & ACBSP & .47 & .306 & .276 & -.25 & 1.20 \\
\hline \multirow[t]{6}{*}{ Entrance Interviews } & AACSB & ACBSP & .26 & .203 & .411 & -.22 & .74 \\
\hline & & IACBE & -.40 & .226 & .190 & -.93 & .14 \\
\hline & ACBSP & AACSB & -.26 & .203 & .411 & -.74 & .22 \\
\hline & & IACBE & $-.66 *$ & .250 & $.027 *$ & -1.25 & -.06 \\
\hline & IACBE & AACSB & .40 & .226 & .190 & -.14 & .93 \\
\hline & & ACBSP & $.66^{*}$ & .250 & $.027 *$ & .06 & 1.25 \\
\hline
\end{tabular}


Table 62 Continued

Tukey's HSD Test of Multiple Comparisons Principle $2 b$

\begin{tabular}{|c|c|c|c|c|c|c|c|}
\hline \multirow[t]{2}{*}{ Dependent Variable } & \multirow[t]{2}{*}{ Accreditation } & \multirow[t]{2}{*}{ Accreditation } & \multirow[t]{2}{*}{$M_{\text {diff }}$} & \multirow[t]{2}{*}{$S E$} & \multirow[t]{2}{*}{$p$} & \multicolumn{2}{|c|}{$95 \%$ Confidence Interval } \\
\hline & & & & & & Lower Bound & Upper Bound \\
\hline \multirow[t]{6}{*}{ Exit Interviews } & \multirow[t]{2}{*}{ AACSB } & ACBSP & .60 & .322 & .155 & -.17 & 1.36 \\
\hline & & IACBE & .34 & .357 & .611 & -.51 & 1.19 \\
\hline & \multirow[t]{2}{*}{ ACBSP } & AACSB & -.60 & .322 & .155 & -1.36 & .17 \\
\hline & & IACBE & -.26 & .396 & .789 & -1.20 & .68 \\
\hline & \multirow[t]{2}{*}{ IACBE } & AACSB & -.34 & .357 & .611 & -1.19 & .51 \\
\hline & & ACBSP & .26 & .396 & .789 & -.68 & 1.20 \\
\hline \multirow[t]{6}{*}{ Focus Groups } & \multirow[t]{2}{*}{ AACSB } & ACBSP & .53 & .257 & .099 & -.08 & 1.14 \\
\hline & & IACBE & -.07 & .285 & .965 & -.75 & .61 \\
\hline & \multirow[t]{2}{*}{ ACBSP } & AACSB & -.53 & .257 & .099 & -1.14 & .08 \\
\hline & & IACBE & -.61 & .317 & .139 & -1.36 & .15 \\
\hline & \multirow[t]{2}{*}{ IACBE } & AACSB & .07 & .285 & .965 & -.61 & .75 \\
\hline & & ACBSP & .61 & .317 & .139 & -.15 & 1.36 \\
\hline \multirow[t]{6}{*}{ Employer Surveys } & \multirow[t]{2}{*}{ AACSB } & ACBSP & .30 & .257 & .482 & -.31 & .91 \\
\hline & & IACBE & .15 & .286 & .854 & -.53 & .83 \\
\hline & \multirow[t]{2}{*}{ ACBSP } & AACSB & -.30 & .257 & .482 & -.91 & .31 \\
\hline & & IACBE & -.14 & .317 & .891 & -.90 & .61 \\
\hline & \multirow[t]{2}{*}{ IACBE } & AACSB & -.15 & .286 & .854 & -.83 & .53 \\
\hline & & ACBSP & .14 & .317 & .891 & -.61 & .90 \\
\hline
\end{tabular}


Table 62 Continued

Tukey's HSD Test of Multiple Comparisons Principle $2 b$

\begin{tabular}{|c|c|c|c|c|c|c|c|}
\hline \multirow[t]{2}{*}{ Dependent Variable } & \multirow[t]{2}{*}{ Accreditation } & \multirow[t]{2}{*}{ Accreditation } & \multirow[t]{2}{*}{$M_{\text {diff }}$} & \multirow[t]{2}{*}{$S E$} & \multirow[t]{2}{*}{$p$} & \multicolumn{2}{|c|}{ 95\% Confidence Interval } \\
\hline & & & & & & Lower Bound & Upper Bound \\
\hline \multirow[t]{6}{*}{$\begin{array}{l}\text { Student Satisfaction } \\
\text { Surveys }\end{array}$} & AACSB & ACBSP & .31 & .275 & .492 & -.34 & .97 \\
\hline & & IACBE & -.53 & .305 & .200 & -1.25 & .20 \\
\hline & ACBSP & AACSB & -.31 & .275 & .492 & -.97 & .34 \\
\hline & & IACBE & $-.84 *$ & .338 & $.038 *$ & -1.64 & -.04 \\
\hline & IACBE & AACSB & .53 & .305 & .200 & -.20 & 1.25 \\
\hline & & ACBSP & $.84^{*}$ & .338 & $.038 *$ & .04 & 1.64 \\
\hline \multirow[t]{6}{*}{ Alumni Surveys } & AACSB & ACBSP & .12 & .262 & .882 & -.50 & .75 \\
\hline & & IACBE & -.31 & .291 & .543 & -1.00 & .38 \\
\hline & ACBSP & AACSB & -.12 & .262 & .882 & -.75 & .50 \\
\hline & & IACBE & -.43 & .322 & .376 & -1.20 & .33 \\
\hline & IACBE & AACSB & .31 & .291 & .543 & -.38 & 1.00 \\
\hline & & ACBSP & .43 & .322 & .376 & -.33 & 1.20 \\
\hline
\end{tabular}


Table 62 Continued

Tukey's HSD Test of Multiple Comparisons Principle $2 b$

\begin{tabular}{|c|c|c|c|c|c|c|c|}
\hline \multirow[t]{2}{*}{ Dependent Variable } & \multirow[t]{2}{*}{ Accreditation } & \multirow[t]{2}{*}{ Accreditation } & \multirow[t]{2}{*}{$M_{\text {diff }}$} & \multirow[t]{2}{*}{$S E$} & \multirow[t]{2}{*}{$p$} & \multicolumn{2}{|c|}{$95 \%$ Confidence Interval } \\
\hline & & & & & & Lower Bound & Upper Bound \\
\hline \multirow[t]{6}{*}{ Course Evaluations } & $\mathrm{AACSB}$ & ACBSP & -.53 & .276 & .134 & -1.19 & .12 \\
\hline & & IACBE & -.65 & .306 & .091 & -1.37 & .08 \\
\hline & ACBSP & AACSB & .53 & .276 & .134 & -.12 & 1.19 \\
\hline & & IACBE & -.11 & .340 & .940 & -.92 & .69 \\
\hline & IACBE & AACSB & .65 & .306 & .091 & -.08 & 1.37 \\
\hline & & ACBSP & .11 & .340 & .940 & -.69 & .92 \\
\hline
\end{tabular}

Based on observed means.

* The mean difference is significant at the .05 level. 
When the MANOVA for Principle 3 was performed, it was significant at the .05 level (Wilks $\Lambda=.842, F=2.227$ Exact Statistic, $d f=(12,298), p=.011,=.287)$. However, because Box's Test of Equality of Covariance Matrices was significant at the .001-level, we do not reject the Null Hypothesis, that the means of the various variables are not different over the groups, based on the multivariate test statistics. Although the multivariate ANOVA is not considered robust due to the violation, because these values are based on a 5-point likert scale which limits some of the potential for variance, the values are still interesting to review. The significant Box statistic is probably caused by the lack of similar group variances (especially in the high variability in ACBSP) and unequal group sizes, along with the underlying distribution not being normal. Box's test is “strongly affected by violations of normality" (Leech, Barrett, Morgan, 2005, p. 167) and this significance may not be accurate.

Even though the multivariate analysis was in violation of a required MANOVA assumption, the means analysis and univariate tests are still valid. The means by accreditation agency indicate that overall, units follow this principle (overall means ranged from 3.78 to 4.27) (see Table 62). Interestingly, the connection of outcomes to the unit mission was found to be the highest mean in this group; however, it was still less than the mean for question 17, which asked the degree the unit mission is reflected in the stated outcomes or assessment activities of the unit (mean $=4.48$, which equates to mid-way between very clear and somewhat clear). The indication of individual assessment goals was the lowest mean area for this principle. There were two significant differences by accreditation body, as shown by the univariate analysis (see Table 63), and both relate to the assessment plan. Specifically, they are the Assessment Plan has Clear Goals, and the Assessment has Clear Student Learning Outcomes. The highest mean group for these two questions was IACBE which had a mean of 4.43 for each question. AACSB had means 
that were in the middle of the other two agencies and ACBSP had the lowest mean (for both questions it was below 4).

Table 62

Means of Principle 3 by Accreditation Agency

\begin{tabular}{|c|c|c|c|c|}
\hline & Accreditation & $M$ & $S D$ & $N$ \\
\hline \multirow{4}{*}{$\begin{array}{l}\text { Assessment Plan has Clear } \\
\text { Goals }\end{array}$} & AACSB & 4.14 & .643 & 77 \\
\hline & ACBSP & 3.89 & 1.071 & 45 \\
\hline & IACBE & 4.43 & .608 & 35 \\
\hline & Total & 4.13 & .801 & 157 \\
\hline \multirow{4}{*}{$\begin{array}{l}\text { Assessment Plan has Clear } \\
\text { Student Learning Outcomes }\end{array}$} & AACSB & 4.06 & .732 & 77 \\
\hline & ACBSP & 3.91 & 1.062 & 45 \\
\hline & IACBE & 4.43 & .502 & 35 \\
\hline & Total & 4.10 & .818 & 157 \\
\hline \multirow{4}{*}{$\begin{array}{l}\text { Objective Measures are } \\
\text { Stated Clearly in Plan }\end{array}$} & AACSB & 3.94 & .800 & 77 \\
\hline & ACBSP & 3.78 & 1.042 & 45 \\
\hline & IACBE & 4.17 & .857 & 35 \\
\hline & Total & 3.94 & .893 & 157 \\
\hline \multirow{4}{*}{$\begin{array}{l}\text { Outcomes are Connected to } \\
\text { Unit Mission, Vision, and } \\
\text { Goals }\end{array}$} & AACSB & 4.29 & .686 & 77 \\
\hline & ACBSP & 4.11 & .804 & 45 \\
\hline & IACBE & 4.43 & .558 & 35 \\
\hline & Total & 4.27 & .701 & 157 \\
\hline \multirow{4}{*}{$\begin{array}{l}\text { Outcomes are Connected to } \\
\text { Institution Mission, Vision, } \\
\text { and Goals }\end{array}$} & AACSB & 4.03 & .778 & 77 \\
\hline & ACBSP & 4.20 & .786 & 45 \\
\hline & IACBE & 4.31 & .583 & 35 \\
\hline & Total & 4.14 & .746 & 157 \\
\hline \multirow{4}{*}{$\begin{array}{l}\text { Assessment Plan Indicates } \\
\text { Goals of Individual } \\
\text { Assessments }\end{array}$} & AACSB & 3.79 & .879 & 77 \\
\hline & ACBSP & 3.58 & .892 & 45 \\
\hline & IACBE & 4.03 & .707 & 35 \\
\hline & Total & 3.78 & .857 & 157 \\
\hline
\end{tabular}


Table 63

Principle 3 Univariate Test Results

\begin{tabular}{|c|c|c|c|c|c|c|c|}
\hline Dependent Variable & & $S S$ & $d f$ & $M S$ & $F$ & $p$ & $\eta^{2}$ \\
\hline \multirow{2}{*}{$\begin{array}{l}\text { Assessment Plan has } \\
\text { Clear Goals }\end{array}$} & Contrast & 5.747 & 2 & 2.873 & 4.685 & .011 & .057 \\
\hline & Error & 94.444 & 154 & .613 & & & \\
\hline \multirow{2}{*}{$\begin{array}{l}\text { Assessment Plan has } \\
\text { Clear Student Learning } \\
\text { Outcomes }\end{array}$} & Contrast & 5.478 & 2 & 2.739 & 4.266 & .016 & .052 \\
\hline & Error & 98.891 & 154 & .642 & & & \\
\hline \multirow{3}{*}{$\begin{array}{l}\text { Objective Measures } \\
\text { are Stated Clearly in } \\
\text { Plan }\end{array}$} & Contrast & 3.060 & 2 & 1.530 & 1.940 & .147 & .025 \\
\hline & & 121.42 & & & & & \\
\hline & Error & 5 & 154 & .788 & & & \\
\hline \multirow{3}{*}{$\begin{array}{l}\text { Outcomes are } \\
\text { Connected to Unit } \\
\text { Mission, Vision, and } \\
\text { Goals }\end{array}$} & Contrast & 2.034 & 2 & 1.017 & 2.096 & .126 & .026 \\
\hline & & & & & & & \\
\hline & Error & 74.730 & 154 & .485 & & & \\
\hline \multirow{3}{*}{$\begin{array}{l}\text { Outcomes are } \\
\text { Connected to } \\
\text { Institution Mission, } \\
\text { Vision, and Goals }\end{array}$} & Contrast & 2.226 & 2 & 1.113 & 2.024 & .136 & .026 \\
\hline & & & & & & & \\
\hline & Error & 84.691 & 154 & .550 & & & \\
\hline \multirow{3}{*}{$\begin{array}{l}\text { Assessment Plan } \\
\text { Indicates Goals of } \\
\text { Individual } \\
\text { Assessments }\end{array}$} & Contrast & 4.012 & 2 & 2.006 & 2.793 & .064 & .035 \\
\hline & & 110.62 & & & & & \\
\hline & Error & 5 & 154 & .718 & & & \\
\hline
\end{tabular}

The MANOVA for Principle 4 did not reveal a significant model. In fact, there were little differences in the means by accreditation for all of the questions in this category. The largest mean difference in accreditation agency among these questions was only .27 (ACBSP and IACBE consideration of curriculum). This indicates that business units accredited by all three agencies equally consider the experiences leading to assessment outcomes (see Table 64). 
Table 64

Means of Principle 4 by Accreditation Agency

\begin{tabular}{|c|c|c|c|c|}
\hline & Accreditation & $M$ & $S D$ & $N$ \\
\hline \multirow{4}{*}{$\begin{array}{l}\text { Assessment Development } \\
\text { Considers Student } \\
\text { Experiences }\end{array}$} & AACSB & 3.46 & .907 & 78 \\
\hline & ACBSP & 3.55 & .904 & 47 \\
\hline & IACBE & 3.68 & .878 & 34 \\
\hline & Total & 3.53 & .899 & 159 \\
\hline \multirow{4}{*}{$\begin{array}{l}\text { Assessment Development } \\
\text { Considers Curriculum } \\
\text { Content }\end{array}$} & AACSB & 4.22 & .573 & 78 \\
\hline & ACBSP & 4.02 & .847 & 47 \\
\hline & IACBE & 4.29 & .719 & 34 \\
\hline & Total & 4.18 & .698 & 159 \\
\hline \multirow{4}{*}{$\begin{array}{l}\text { Assessment Development } \\
\text { Considers Teaching Styles }\end{array}$} & AACSB & 2.96 & 1.086 & 78 \\
\hline & ACBSP & 2.94 & .942 & 47 \\
\hline & IACBE & 3.18 & .936 & 34 \\
\hline & Total & 3.00 & 1.013 & 159 \\
\hline \multirow{4}{*}{$\begin{array}{l}\text { Assessment Purpose is } \\
\text { Considered when Planning } \\
\text { Assessment Activities }\end{array}$} & AACSB & 3.65 & .923 & 78 \\
\hline & ACBSP & 3.68 & .935 & 47 \\
\hline & IACBE & 3.62 & .817 & 34 \\
\hline & Total & 3.65 & .900 & 159 \\
\hline
\end{tabular}

The MANOVA for Principle 5 did not reveal a significant model. The means were high in this area, ranging from a total mean of 3.95 to 4.25 . By accreditation agency, again, there were little differences in the means (see Table 65). Even though the MANOVA results did not indicate a significant model, the univariate analysis (see ) indicated a slightly significant difference in responses to the question that asked if Improvements are Made Based on Assessment Results. The Tukey HSD test also found a significant model for this question and indicated that AACSB and IACBE, with a mean difference of .32, were not homogonous subsets (see Table 67). Although all reported that they agreed improvements were made based on assessment results, 
business units accredited by IACBE reported making improvements based on results significantly more frequently than AACSB units.

Table 65

Means of Principle 5 by Accreditation Agency

\begin{tabular}{lcccc}
\hline & Accreditation & $M$ & $S D$ & $N$ \\
\hline Assessment is On-Going & AACSB & 4.25 & .610 & 77 \\
Continuous Improvement & ACBSP & 4.11 & .787 & 47 \\
Process & IACBE & 4.30 & .847 & 33 \\
& Total & 4.22 & .719 & 157 \\
Assessment Process is & AACSB & 4.01 & .752 & 77 \\
Evaluated Periodically & ACBSP & 3.85 & .807 & 47 \\
& IACBE & 4.03 & .810 & 33 \\
& Total & 3.97 & .780 & 157 \\
Assessment Results are & AACSB & 3.91 & .747 & 77 \\
Compared Over Time and & ACBSP & 3.89 & .890 & 47 \\
Verify Progression Toward & IACBE & 4.12 & .650 & 33 \\
Goals & Total & 3.95 & .775 & 157 \\
& AACSB & 4.10 & .640 & 77 \\
Improvements are Made & ACBSP & 4.13 & .711 & 47 \\
Based on Assessment Results & IACBE & 4.42 & .502 & 33 \\
& Total & 4.18 & .646 & 157 \\
\hline
\end{tabular}


Table 66

Principle 5 Univariate Test Results

\begin{tabular}{|c|c|c|c|c|c|c|c|}
\hline Dependent Variable & & $S S$ & $d f$ & $M S$ & $F$ & $p$ & $\eta^{2}$ \\
\hline \multirow{2}{*}{$\begin{array}{l}\text { Assessment is On-Going } \\
\text { Continuous Improvement } \\
\text { Process }\end{array}$} & Contrast & .887 & 2 & .444 & .857 & .427 & .011 \\
\hline & Error & 79.749 & 154 & .518 & & & \\
\hline \multirow{2}{*}{$\begin{array}{l}\text { Assessment Process is } \\
\text { Evaluated Periodically }\end{array}$} & Contrast & .927 & 2 & .463 & .760 & .470 & .010 \\
\hline & Error & 93.914 & 154 & .610 & & & \\
\hline \multirow{2}{*}{$\begin{array}{l}\text { Assessment Results are } \\
\text { Compared Over Time and } \\
\text { Verify Progression Toward } \\
\text { Goals }\end{array}$} & Contrast & 1.245 & 2 & .623 & 1.039 & .356 & .013 \\
\hline & Error & 92.347 & 154 & .600 & & & \\
\hline \multirow{2}{*}{$\begin{array}{l}\text { Improvements are Made } \\
\text { Based on Assessment } \\
\text { Results }\end{array}$} & Contrast & 2.543 & 2 & 1.271 & 3.135 & $.046 *$ & .039 \\
\hline & Error & 62.463 & 154 & .406 & & & \\
\hline
\end{tabular}


Table 67

Tukey's HSD Test of Multiple Comparisons Principle 5

\begin{tabular}{|c|c|c|c|c|c|c|c|}
\hline \multirow[t]{2}{*}{ Dependent Variable } & \multirow[t]{2}{*}{ Accreditation } & \multirow[t]{2}{*}{ Accreditation } & \multirow[t]{2}{*}{$M_{\text {diff }}$} & \multirow[t]{2}{*}{$S E$} & \multirow[t]{2}{*}{$p$} & \multicolumn{2}{|c|}{$95 \%$ Confidence Interval } \\
\hline & & & & & & Lower Bound & Upper Bound \\
\hline \multirow{6}{*}{$\begin{array}{l}\text { Assessment is On- } \\
\text { Going Continuous } \\
\text { Improvement Process }\end{array}$} & AACSB & ACBSP & .14 & .133 & .544 & -.17 & .46 \\
\hline & & IACBE & -.06 & .150 & .925 & -.41 & .30 \\
\hline & ACBSP & AACSB & -.14 & .133 & .544 & -.46 & .17 \\
\hline & & IACBE & -.20 & .163 & .453 & -.58 & .19 \\
\hline & IACBE & AACSB & .06 & .150 & .925 & -.30 & .41 \\
\hline & & ACBSP & .20 & .163 & .453 & -.19 & .58 \\
\hline \multirow[t]{6}{*}{$\begin{array}{l}\text { Assessment Process is } \\
\text { Evaluated Preiodically }\end{array}$} & $\mathrm{AACSB}$ & ACBSP & .16 & .145 & .503 & -.18 & .50 \\
\hline & & IACBE & -.02 & .162 & .994 & -.40 & .37 \\
\hline & ACBSP & AACSB & -.16 & .145 & .503 & -.50 & .18 \\
\hline & & IACBE & -.18 & .177 & .571 & -.60 & .24 \\
\hline & IACBE & AACSB & .02 & .162 & .994 & -.37 & .40 \\
\hline & & ACBSP & .18 & .177 & .571 & -.24 & .60 \\
\hline
\end{tabular}


Table 68 Continued

Tukey's HSD Test of Multiple Comparisons Principle 5

\begin{tabular}{|c|c|c|c|c|c|c|c|}
\hline \multirow[t]{2}{*}{ Dependent Variable } & \multirow[t]{2}{*}{ Accreditation } & \multirow[t]{2}{*}{ Accreditation } & \multirow[t]{2}{*}{$M_{\text {diff }}$} & \multirow[t]{2}{*}{$S E$} & \multirow[t]{2}{*}{$p$} & \multicolumn{2}{|c|}{ 95\% Confidence Interval } \\
\hline & & & & & & Lower Bound & Upper Bound \\
\hline \multirow{7}{*}{$\begin{array}{l}\text { Assessment Results } \\
\text { are Compared Over } \\
\text { Time and Verify } \\
\text { Progression Toward } \\
\text { Goals }\end{array}$} & AACSB & ACBSP & & & & & \\
\hline & & & .02 & .143 & .994 & -.32 & .35 \\
\hline & & IACBE & -.21 & .161 & .388 & -.59 & .17 \\
\hline & ACBSP & AACSB & -.02 & .143 & .994 & -.35 & .32 \\
\hline & & IACBE & -.23 & .176 & .401 & -.64 & .19 \\
\hline & IACBE & AACSB & .21 & .161 & .388 & -.17 & .59 \\
\hline & & ACBSP & .23 & .176 & .401 & -.19 & .64 \\
\hline \multirow{6}{*}{$\begin{array}{l}\text { Improvements are } \\
\text { Made Based on } \\
\text { Assessment Results }\end{array}$} & AACSB & ACBSP & -.02 & .118 & .978 & -.30 & .26 \\
\hline & & IACBE & $-.32 *$ & .133 & $.044 *$ & -.63 & -.01 \\
\hline & ACBSP & AACSB & .02 & .118 & .978 & -.26 & .30 \\
\hline & & IACBE & -.30 & .145 & .104 & -.64 & .05 \\
\hline & IACBE & AACSB & $.32 *$ & .133 & $.044^{*}$ & .01 & .63 \\
\hline & & ACBSP & .30 & .145 & .104 & -.05 & .64 \\
\hline
\end{tabular}

* The mean difference is significant at the .05 level. 
The Principle 6 MANOVA did not reveal a significant model. All of the accreditation agency means were found to be harmonious by Turkey's HSD (see Table 71). The means varied by accreditation group for all of Principle 6's questions as the standard deviations for each of the questions in this group were all above .75 and many were very near or above 1 (see Table 69). A significant difference in the pair-wise comparison was found in the univariate test for the question that asked if the assessment effort was campus wide (see Table 70).

Table 69

Means of Principle 6 by Accreditation Agency

\begin{tabular}{lcccc}
\hline & Accreditation & $M$ & $S D$ & $N$ \\
\hline Assessment Effort is Campus & AACSB & 3.74 & 1.129 & 77 \\
Wide & ACBSP & 4.18 & .843 & 44 \\
& IACBE & 4.11 & .867 & 35 \\
& Total & 3.95 & 1.015 & 156 \\
Whole Faculty Participates - & AACSB & 3.44 & 1.006 & 77 \\
Not Individual Effort & ACBSP & 3.55 & 1.150 & 44 \\
& IACBE & 3.74 & .852 & 35 \\
& Total & 3.54 & 1.018 & 156 \\
Unit Outcomes are & AACSB & 3.87 & .767 & 77 \\
Developed by Discipline & ACBSP & 3.68 & .983 & 44 \\
Collaboration & IACBE & 3.80 & .797 & 35 \\
& Total & 3.80 & .838 & 156 \\
Individuals Beyond campus & AACSB & 3.56 & .896 & 77 \\
Community are Included in & ACBSP & 3.50 & 1.131 & 44 \\
Assessment Process & IACBE & 3.49 & 1.067 & 35 \\
& Total & 3.53 & 1.000 & 156 \\
\hline & & & &
\end{tabular}


Table 70

Principle 6 Univariate Test Results

\begin{tabular}{|c|c|c|c|c|c|c|c|}
\hline Dependent Variable & & $S S$ & $d f$ & $M S$ & $F$ & $p$ & $\eta^{2}$ \\
\hline \multirow{2}{*}{$\begin{array}{l}\text { Assessment Effort is } \\
\text { Campus Wide }\end{array}$} & Contrast & 6.696 & 2 & 3.348 & 3.350 & .038 & .042 \\
\hline & Error & 152.894 & 153 & .999 & & & \\
\hline \multirow{2}{*}{$\begin{array}{l}\text { Whole Faculty } \\
\text { Participates - Not } \\
\text { Individual Effort }\end{array}$} & Contrast & 2.187 & 2 & 1.094 & 1.055 & .351 & .014 \\
\hline & Error & 158.582 & 153 & 1.036 & & & \\
\hline \multirow{2}{*}{$\begin{array}{l}\text { Unit Outcomes are } \\
\text { Developed by Discipline } \\
\text { Collaboration }\end{array}$} & Contrast & .993 & 2 & .496 & .704 & .496 & .009 \\
\hline & Error & 107.847 & 153 & .705 & & & \\
\hline \multirow{2}{*}{$\begin{array}{l}\text { Individuals Beyond } \\
\text { Campus Community are } \\
\text { Included in Assessment } \\
\text { Process }\end{array}$} & Contrast & .168 & 2 & .084 & .083 & .921 & .001 \\
\hline & Error & 154.730 & 153 & 1.011 & & & \\
\hline
\end{tabular}


Table 71

Tukey's HSD Test of Multiple Comparisons Principle 6

\begin{tabular}{|c|c|c|c|c|c|c|c|}
\hline \multirow[t]{2}{*}{ Dependent Variable } & \multirow[t]{2}{*}{ Accreditation } & \multirow[t]{2}{*}{ Accreditation } & \multirow[t]{2}{*}{$M_{\text {diff }}$} & \multirow[t]{2}{*}{$S E$} & \multirow[t]{2}{*}{$p$} & \multicolumn{2}{|c|}{$95 \%$ Confidence Interval } \\
\hline & & & & & & Lower Bound & Upper Bound \\
\hline \multirow{6}{*}{$\begin{array}{l}\text { Assessment Effort is } \\
\text { Campus Wide }\end{array}$} & AACSB & ACBSP & -.44 & .189 & .054 & -.89 & .01 \\
\hline & & IACBE & -.37 & .204 & .162 & -.86 & .11 \\
\hline & ACBSP & AACSB & .44 & .189 & .054 & -.01 & .89 \\
\hline & & IACBE & .07 & .226 & .952 & -.47 & .60 \\
\hline & IACBE & AACSB & .37 & .204 & .162 & -.11 & .86 \\
\hline & & ACBSP & -.07 & .226 & .952 & -.60 & .47 \\
\hline \multirow{6}{*}{$\begin{array}{l}\text { Whole Faculty } \\
\text { Participates - Not } \\
\text { Individual Effort }\end{array}$} & AACSB & ACBSP & -.10 & .192 & .852 & -.56 & .35 \\
\hline & & IACBE & -.30 & .208 & .317 & -.79 & .19 \\
\hline & ACBSP & AACSB & .10 & .192 & .852 & -.35 & .56 \\
\hline & & IACBE & -.20 & .231 & .669 & -.74 & .35 \\
\hline & IACBE & AACSB & .30 & .208 & .317 & -.19 & .79 \\
\hline & & ACBSP & .20 & .231 & .669 & -.35 & .74 \\
\hline
\end{tabular}


Table 72 Continued

Tukey's HSD Test of Multiple Comparisons Principle 6

\begin{tabular}{|c|c|c|c|c|c|c|c|}
\hline \multirow[t]{2}{*}{ Dependent Variable } & \multirow[t]{2}{*}{ Accreditation } & \multirow[t]{2}{*}{ Accreditation } & \multirow[t]{2}{*}{$M_{\text {diff }}$} & \multirow[t]{2}{*}{$S E$} & \multirow[t]{2}{*}{$p$} & \multicolumn{2}{|c|}{$95 \%$ Confidence Interval } \\
\hline & & & & & & Lower Bound & Upper Bound \\
\hline \multirow{7}{*}{$\begin{array}{l}\text { Unit Outcomes are } \\
\text { Developed by } \\
\text { Discipline } \\
\text { Collaboration }\end{array}$} & AACSB & ACBSP & & & & & \\
\hline & & & .19 & .159 & .463 & -.19 & .56 \\
\hline & & IACBE & .07 & .171 & .912 & -.33 & .48 \\
\hline & ACBSP & AACSB & -.19 & .159 & .463 & -.56 & .19 \\
\hline & & IACBE & -.12 & .190 & .809 & -.57 & .33 \\
\hline & IACBE & AACSB & -.07 & .171 & .912 & -.48 & .33 \\
\hline & & ACBSP & .12 & .190 & .809 & -.33 & .57 \\
\hline \multirow{6}{*}{$\begin{array}{l}\text { Individuals Beyond } \\
\text { campus Community } \\
\text { are Included in } \\
\text { Assessment Process }\end{array}$} & AACSB & ACBSP & .06 & .190 & .949 & -.39 & .51 \\
\hline & & IACBE & .07 & .205 & .933 & -.41 & .56 \\
\hline & ACBSP & AACSB & -.06 & .190 & .949 & -.51 & .39 \\
\hline & & IACBE & .01 & .228 & .998 & -.52 & .55 \\
\hline & IACBE & AACSB & -.07 & .205 & .933 & -.56 & .41 \\
\hline & & ACBSP & -.01 & .228 & .998 & -.55 & .52 \\
\hline
\end{tabular}

* The mean difference is significant at the .05 level. 
The MANOVA for Principle 7 did not reveal a significant model. There were little differences in the means by accreditation for all of the questions in this category. Once again, IACBE had the highest mean values for each question (see Table 73). AACSB had the lowest means with the exception of the statement that said Outcomes are Learner Centered, where ACBSP had a lower mean value.

Table 73

Means of Principle 7 by Accreditation Agency

\begin{tabular}{lcccc}
\hline & Accreditation & $M$ & $S D$ & $N$ \\
\hline Measured Items are & AACSB & 3.97 & .664 & 78 \\
Important and Relevant to & ACBSP & 4.02 & .931 & 46 \\
Unit Decision Making & IACBE & 4.11 & .622 & 36 \\
& Total & 4.02 & .739 & 160 \\
Outcomes are Learner- & AACSB & 3.85 & .740 & 78 \\
Centered & ACBSP & 3.78 & .814 & 46 \\
& IACBE & 4.14 & .593 & 36 \\
& Total & 3.89 & .741 & 160 \\
Outcomes Focus on & AACSB & 4.03 & .683 & 78 \\
Improving Learner & ACBSP & 4.20 & .654 & 46 \\
Knowledge & IACBE & 4.25 & .500 & 36 \\
& Total & 4.13 & .642 & 160 \\
& AACSB & 4.09 & .885 & 78 \\
Assessment Results are & ACBSP & 4.26 & .773 & 46 \\
Shared with Faculty & IACBE & 4.33 & .676 & 36 \\
& Total & 4.19 & .813 & 160 \\
\hline & & & &
\end{tabular}

Principle 8 did not show a significant model for the MANOVA; however, there were two areas in the univariate analysis that were significant at the .05-level (see Table 75). The two statements that indicated a significant difference were that assessment was part of the culture and 
that assessment was part of internal review. In each significant difference, IACBE accredited units reported stronger agreement with assessment as part of their culture and as part of their internal program review. These two areas also were significant in Tukey's HSD model (see Table 76). There was some deviation in the means by accreditation group, with the exception of the statement concerning faculty incentives (see Table 74). Units representing all three accreditation agencies agree (.09 largest mean difference), that faculty are not generally provided incentives.

Table 74

Means of Principle 8 by Accreditation Agency

\begin{tabular}{lcccc}
\hline & Accreditation & $M$ & $S D$ & $N$ \\
\hline Assessment is Part of Culture & AACSB & 3.25 & 1.006 & 79 \\
& ACBSP & 3.66 & 1.089 & 47 \\
& IACBE & 3.88 & .927 & 33 \\
Faculty Receive Incentives & Total & 3.50 & 1.043 & 159 \\
& AACSB & 2.39 & 1.031 & 79 \\
& ACBSP & 2.30 & .998 & 47 \\
Whole Faculty Participates - & IACBE & 2.39 & 1.029 & 33 \\
Not Individual Effort & Total & 2.36 & 1.015 & 159 \\
& AACSB & 3.47 & 1.011 & 79 \\
& ACBSP & 3.60 & 1.136 & 47 \\
& IACBE & 3.76 & .830 & 33 \\
Assessment is Part of Internal & Total & 3.57 & 1.016 & 159 \\
& AACSB & 3.84 & .823 & 79 \\
& ACBSP & 3.96 & .833 & 47 \\
& IACBE & 4.27 & .801 & 33 \\
& Total & 3.96 & .834 & 159 \\
\hline
\end{tabular}


Table 75

Principle 8 Univariate Test Results

\begin{tabular}{|c|c|c|c|c|c|c|c|}
\hline Dependent Variable & & $S S$ & $d f$ & $M S$ & $F$ & $p$ & $\eta^{2}$ \\
\hline \multirow{2}{*}{$\begin{array}{l}\text { Assessment is Part of } \\
\text { Culture }\end{array}$} & Contrast & 10.743 & 2 & 5.372 & \multirow[t]{2}{*}{5.205} & \multirow[t]{2}{*}{$.006 *$} & \multirow[t]{2}{*}{.063} \\
\hline & Error & 161.005 & 156 & 1.032 & & & \\
\hline \multirow{2}{*}{$\begin{array}{l}\text { Faculty Receive } \\
\text { Incentives }\end{array}$} & Contrast & .299 & 2 & .149 & \multirow[t]{2}{*}{.143} & \multirow[t]{2}{*}{.867} & \multirow[t]{2}{*}{.002} \\
\hline & Error & 162.544 & 156 & 1.042 & & & \\
\hline \multirow{2}{*}{$\begin{array}{l}\text { Whole Faculty } \\
\text { Participates - Not } \\
\text { Individual Effort }\end{array}$} & Contrast & 2.006 & 2 & 1.003 & \multirow[t]{2}{*}{.972} & \multirow[t]{2}{*}{.381} & \multirow[t]{2}{*}{.012} \\
\hline & Error & 161.051 & 156 & 1.032 & & & \\
\hline \multirow{2}{*}{$\begin{array}{l}\text { Assessment is Part of } \\
\text { Internal Program Review }\end{array}$} & Contrast & 4.452 & 2 & 2.226 & \multirow[t]{2}{*}{3.297} & \multirow[t]{2}{*}{$.040 *$} & \multirow[t]{2}{*}{.041} \\
\hline & Error & 105.321 & 156 & .675 & & & \\
\hline
\end{tabular}

Note. The F tests the effect of Accreditation. This test is based on the linearly independent pairwise comparisons among the estimated marginal means.

Computed using alpha $=.05$ 
Table 76

Tukey's HSD Test of Multiple Comparisons Principle 8

\begin{tabular}{|c|c|c|c|c|c|c|c|}
\hline \multirow[t]{2}{*}{ Dependent Variable } & \multirow[t]{2}{*}{ Accreditation } & \multirow[t]{2}{*}{ Accreditation } & \multirow[t]{2}{*}{$M_{\text {diff }}$} & \multirow[t]{2}{*}{$S E$} & \multirow[t]{2}{*}{$p$} & \multicolumn{2}{|c|}{$95 \%$ Confidence Interval } \\
\hline & & & & & & Lower Bound & Upper Bound \\
\hline \multirow[t]{6}{*}{$\begin{array}{l}\text { Assessment is Part of } \\
\text { Culture }\end{array}$} & AACSB & ACBSP & -.41 & .187 & .079 & -.85 & .04 \\
\hline & & IACBE & $-.63 *$ & .211 & $.010^{*}$ & -1.12 & -.13 \\
\hline & ACBSP & AACSB & .41 & .187 & .079 & -.04 & .85 \\
\hline & & IACBE & -.22 & .231 & .609 & -.77 & .33 \\
\hline & IACBE & AACSB & $.63^{*}$ & .211 & $.010^{*}$ & .13 & 1.12 \\
\hline & & ACBSP & .22 & .231 & .609 & -.33 & .77 \\
\hline \multirow[t]{6}{*}{ Faculty Incentives } & AACSB & ACBSP & .09 & .188 & .870 & -.35 & .54 \\
\hline & & IACBE & .00 & .212 & 1.000 & -.50 & .50 \\
\hline & ACBSP & AACSB & -.09 & .188 & .870 & -.54 & .35 \\
\hline & & IACBE & -.10 & .232 & .910 & -.64 & .45 \\
\hline & IACBE & AACSB & .00 & .212 & 1.000 & -.50 & .50 \\
\hline & & ACBSP & .10 & .232 & .910 & -.45 & .64 \\
\hline
\end{tabular}


Table 77 Continued

Tukey's HSD Test of Multiple Comparisons Principle 8

\begin{tabular}{|c|c|c|c|c|c|c|c|}
\hline \multirow[t]{2}{*}{ Dependent Variable } & \multirow[t]{2}{*}{ Accreditation } & \multirow[t]{2}{*}{ Accreditation } & \multirow[t]{2}{*}{$M_{\text {diff }}$} & \multirow[t]{2}{*}{$S E$} & \multirow[t]{2}{*}{$p$} & \multicolumn{2}{|c|}{$95 \%$ Confidence Interval } \\
\hline & & & & & & Lower Bound & Upper Bound \\
\hline \multirow{6}{*}{$\begin{array}{l}\text { Whole Faculty } \\
\text { Participates - Not } \\
\text { Individual Effort }\end{array}$} & AACSB & ACBSP & -.13 & .187 & .775 & -.57 & .32 \\
\hline & & IACBE & -.29 & .211 & .357 & -.79 & .21 \\
\hline & ACBSP & AACSB & .13 & .187 & .775 & -.32 & .57 \\
\hline & & IACBE & -.16 & .231 & .763 & -.71 & .38 \\
\hline & IACBE & AACSB & .29 & .211 & .357 & -.21 & .79 \\
\hline & & ACBSP & .16 & .231 & .763 & -.38 & .71 \\
\hline \multirow{6}{*}{$\begin{array}{l}\text { Assessment is Part of } \\
\text { Internal Program } \\
\text { Review }\end{array}$} & AACSB & ACBSP & -.12 & .151 & .700 & -.48 & .24 \\
\hline & & IACBE & $-.44 *$ & .170 & $.030 *$ & -.84 & -.03 \\
\hline & ACBSP & AACSB & .12 & .151 & .700 & -.24 & .48 \\
\hline & & IACBE & -.32 & .187 & .212 & -.76 & .13 \\
\hline & IACBE & AACSB & $.44 *$ & .170 & $.030 *$ & .03 & .84 \\
\hline & & ACBSP & .32 & .187 & .212 & -.13 & .76 \\
\hline
\end{tabular}

Based on observed means.

* The mean difference is significant at the .05 level. 
IACBE once again reported the highest level of agreement with Principle 9 practices, followed by ACBSP, and then AACSB (see Table 76). AACSB had the highest mean value for communicating results to the public, although all of the response means were between the levels of neutral and disagree (2.27 to 2.40). Although the overall MANOVA did not identify it, the results of the individual Principle 9 MANOVA indicated a significant difference at the .05-level (Wilks' $\left.\Lambda=.886, F=1.876, d f=(10,300), p=.048, \eta^{2}=.059\right)$. Due to the significant model, the questions were reviewed for structural differences among the variables. The significant difference was found to be in the communication of outcomes to learners across the different accreditation agencies (see Table 77). 
Table 78

Means of Principle 9 by Accreditation Agency

\begin{tabular}{|c|c|c|c|c|}
\hline & Accreditation. & $M$ & $S D$ & $N$ \\
\hline \multirow{4}{*}{$\begin{array}{l}\text { Quality of Teaching } \\
\text { Importance }\end{array}$} & AACSB & 4.65 & .556 & 77 \\
\hline & ACBSP & 4.84 & .370 & 44 \\
\hline & IACBE & 4.75 & .604 & 36 \\
\hline & Total & 4.73 & .526 & 157 \\
\hline \multirow[t]{4}{*}{ Assessment Goals are Shared } & AACSB & 4.08 & .721 & 77 \\
\hline & ACBSP & 4.00 & .988 & 44 \\
\hline & IACBE & 4.22 & .832 & 36 \\
\hline & Total & 4.09 & .827 & 157 \\
\hline \multirow{4}{*}{$\begin{array}{l}\text { Outcomes are Clearly } \\
\text { Communicated to Learners }\end{array}$} & AACSB & 3.26 & .894 & 77 \\
\hline & ACBSP & 3.66 & .963 & 44 \\
\hline & IACBE & 3.72 & .815 & 36 \\
\hline & Total & 3.48 & .917 & 157 \\
\hline \multirow{4}{*}{$\begin{array}{l}\text { Assessment Results are } \\
\text { Reported to Students }\end{array}$} & AACSB & 2.52 & 1.083 & 77 \\
\hline & ACBSP & 2.82 & 1.105 & 44 \\
\hline & IACBE & 2.97 & .971 & 36 \\
\hline & Total & 2.71 & 1.076 & 157 \\
\hline \multirow{4}{*}{$\begin{array}{l}\text { Assessment Results are } \\
\text { Shared with Public }\end{array}$} & AACSB & 2.40 & 1.150 & 77 \\
\hline & ACBSP & 2.27 & .949 & 44 \\
\hline & IACBE & 2.33 & .828 & 36 \\
\hline & Total & 2.35 & 1.024 & 157 \\
\hline
\end{tabular}


Table 79

Principle 9 Univariate Test Results

\begin{tabular}{llrrrrrr}
\hline Dependent Variable & & \multicolumn{1}{c}{$S S$} & $d f$ & $M S$ & $F$ & $P$ & $\eta^{2}$ \\
\hline Quality of Teaching & Contrast & 1.054 & 2 & .527 & 1.925 & .149 & .024 \\
Importance & Error & 42.169 & 154 & .274 & & & \\
Assessment Goals are & Contrast & .997 & 2 & .498 & .726 & .486 & .009 \\
Shared & Error & 105.755 & 154 & .687 & & & \\
Outcomes are Clearly & Contrast & 7.258 & 2 & 3.629 & 4.510 & $.012 *$ & .055 \\
Communicated to & Error & 123.914 & 154 & .805 & & & \\
Learners & Contrast & 5.784 & 2 & 2.892 & 2.549 & .081 & .032 \\
Assessment Results are & Error & 174.738 & 154 & 1.135 & & & \\
Reported to Students & Contrast & .486 & 2 & .243 & .229 & .796 & .003 \\
Assessment Results are & Error & 163.247 & 154 & 1.060 & & & \\
Shared with Public & C. & & & & & \\
\hline
\end{tabular}

Note. The F tests the effect of Accreditation. This test is based on the linearly independent pairwise comparisons among the estimated marginal means.

Computed using alpha $=.05$

Assessment Commitment was tested via a MANOVA and was found to be significant for the group of questions $(18,19,20,21,22)($ Wilks $\Lambda=.999, F=1.930, d f=(10,314), p=.041$, $\left.\eta^{2}=.058\right)$. Specifically, Tukey's HSD test found the business unit faculty commitment to assessment was significantly different between IACBE and AACSB accredited units $\left(M_{\text {diff }}=-\right.$ $.51, \mathrm{p}=.006$ ) (see Table 82 ). The means of the faculty commitment to assessment all indicated that units generally agreed while some were neutral about faculty commitment to assessment (above 3.5), but the mean for IACBE was over the agreement level (above 4), which showed a strong level of commitment across the all accredited units (see Table 80). Interestingly, the unit administration commitment was very similar across all accreditation bodies with a mean difference of only .01 between IACBE and the other two agencies. The univariate test also found 
IACBE reported a significantly higher level of unit faculty commitment than AACSB but no significant differences were identified in the other areas (see Table 78).

Table 80

Means of Assessment Commitment by Accreditation Agency

\begin{tabular}{lcccc}
\hline & Accreditation & $M$ & $S D$ & $N$ \\
\hline Institution Administration & AACSB & 4.27 & .668 & 82 \\
Assessment Commitment & ACBSP & 4.53 & .625 & 45 \\
& IACBE & 4.46 & .605 & 37 \\
& Total & 4.38 & .650 & 164 \\
Unit Administration & AACSB & 4.67 & .589 & 82 \\
Assessment Commitment & ACBSP & 4.67 & .522 & 45 \\
& IACBE & 4.68 & .475 & 37 \\
& Total & 4.67 & .544 & 164 \\
Unit Faculty Assessment & AACSB & 3.57 & .817 & 82 \\
Commitment & ACBSP & 3.80 & .842 & 45 \\
& IACBE & 4.08 & .829 & 37 \\
& Total & 3.75 & .846 & 164 \\
Faculty Provided Incentive & AACSB & 2.35 & .986 & 82 \\
Assessment Commitment & ACBSP & 2.47 & .919 & 45 \\
& IACBE & 2.68 & 1.180 & 37 \\
& Total & 2.46 & 1.017 & 164 \\
Faculty Resistance & AACSB & 2.72 & .906 & 82 \\
Assessment Commitment & ACBSP & 2.82 & 1.072 & 45 \\
& IACBE & 2.41 & .927 & 37 \\
& Total & 2.68 & .965 & 164 \\
\hline
\end{tabular}


Table 81

Assessment Univariate Test Results

\begin{tabular}{|c|c|c|c|c|c|c|c|}
\hline \multicolumn{2}{|l|}{ Dependent Variable } & $S S$ & $d f$ & $M S$ & $F$ & $P$ & $\eta^{2}$ \\
\hline \multirow{2}{*}{$\begin{array}{l}\text { Institution } \\
\text { Administration } \\
\text { Assessment } \\
\text { Commitment }\end{array}$} & Contrast & 2.312 & 2 & 1.156 & 2.799 & .064 & .034 \\
\hline & Error & 66.487 & 161 & .413 & & & \\
\hline \multirow{2}{*}{$\begin{array}{l}\text { Unit Administration } \\
\text { Assessment } \\
\text { Commitment }\end{array}$} & Contrast & .002 & 2 & .001 & .003 & .997 & .000 \\
\hline & Error & 48.218 & 161 & .299 & & & \\
\hline \multirow{2}{*}{$\begin{array}{l}\text { Unit Assessment } \\
\text { Commitment }\end{array}$} & Contrast & 6.732 & 2 & 3.366 & 4.926 & $.008 *$ & .058 \\
\hline & Error & 110.018 & 161 & .683 & & & \\
\hline \multirow{2}{*}{$\begin{array}{l}\text { Faculty Provided } \\
\text { Incentive } \\
\text { Assessment } \\
\text { Commitment }\end{array}$} & Contrast & 2.649 & 2 & 1.325 & 1.284 & .280 & .016 \\
\hline & Error & 166.052 & 161 & 1.031 & & & \\
\hline \multirow{2}{*}{$\begin{array}{l}\text { Faculty Resistance } \\
\text { Assessment } \\
\text { Commitment }\end{array}$} & Contrast & 3.826 & 2 & 1.913 & 2.081 & .128 & .025 \\
\hline & Error & 148.045 & 161 & .920 & & & \\
\hline
\end{tabular}


Table 82

Tukey's HSD Test of Multiple Comparisons Assessment

\begin{tabular}{|c|c|c|c|c|c|c|c|}
\hline \multirow[t]{2}{*}{ Dependent Variable } & \multirow[t]{2}{*}{ Accreditation } & \multirow[t]{2}{*}{ Accreditation } & \multirow[t]{2}{*}{$M_{\text {diff }}$} & \multirow[t]{2}{*}{$S E$} & \multirow[t]{2}{*}{$p$} & \multicolumn{2}{|c|}{$95 \%$ Confidence Interval } \\
\hline & & & & & & Lower Bound & Upper Bound \\
\hline \multirow{7}{*}{$\begin{array}{l}\text { Institution } \\
\text { Administration } \\
\text { Assessment } \\
\text { Commitment }\end{array}$} & AACSB & ACBSP & & & & & \\
\hline & & & -.27 & .119 & .070 & -.55 & .02 \\
\hline & & IACBE & -.19 & .127 & .293 & -.49 & .11 \\
\hline & ACBSP & AACSB & .27 & .119 & .070 & -.02 & .55 \\
\hline & & IACBE & .07 & .143 & .863 & -.26 & .41 \\
\hline & IACBE & AACSB & .19 & .127 & .293 & -.11 & .49 \\
\hline & & ACBSP & -.07 & .143 & .863 & -.41 & .26 \\
\hline \multirow{6}{*}{$\begin{array}{l}\text { Unit Administration } \\
\text { Assessment } \\
\text { Commitment }\end{array}$} & AACSB & ACBSP & .00 & .102 & .999 & -.24 & .24 \\
\hline & & IACBE & .00 & .108 & .999 & -.26 & .25 \\
\hline & ACBSP & AACSB & .00 & .102 & .999 & -.24 & .24 \\
\hline & & IACBE & -.01 & .121 & .997 & -.30 & .28 \\
\hline & IACBE & AACSB & .00 & .108 & .999 & -.25 & .26 \\
\hline & & ACBSP & .01 & .121 & .997 & -.28 & .30 \\
\hline
\end{tabular}


Table 83 Continued

Tukey's HSD Test of Multiple Comparisons Assessment

\begin{tabular}{|c|c|c|c|c|c|c|c|}
\hline \multirow[t]{2}{*}{ Dependent Variable } & \multirow[t]{2}{*}{ Accreditation } & \multirow[t]{2}{*}{ Accreditation } & \multirow[t]{2}{*}{$M_{\text {diff }}$} & \multirow[t]{2}{*}{$S E$} & \multirow[t]{2}{*}{$p$} & \multicolumn{2}{|c|}{$95 \%$ Confidence Interval } \\
\hline & & & & & & Lower Bound & Upper Bound \\
\hline \multirow{7}{*}{$\begin{array}{l}\text { Unit Faculty } \\
\text { Assessment } \\
\text { Commitment }\end{array}$} & AACSB & ACBSP & & & & & \\
\hline & & & -.23 & .153 & .304 & -.59 & .14 \\
\hline & & IACBE & $-.51 *$ & .164 & $.006^{*}$ & -.90 & -.12 \\
\hline & ACBSP & AACSB & .23 & .153 & .304 & -.14 & .59 \\
\hline & & IACBE & -.28 & .183 & .279 & -.72 & .15 \\
\hline & IACBE & AACSB & $.51 *$ & .164 & $.006 *$ & .12 & .90 \\
\hline & & ACBSP & .28 & .183 & .279 & -.15 & .72 \\
\hline \multirow{6}{*}{$\begin{array}{l}\text { Faculty Provided } \\
\text { Incentive for } \\
\text { Assessment }\end{array}$} & AACSB & ACBSP & -.11 & .188 & .820 & -.56 & .33 \\
\hline & & IACBE & -.32 & .201 & .248 & -.80 & .15 \\
\hline & ACBSP & AACSB & .11 & .188 & .820 & -.33 & .56 \\
\hline & & IACBE & -.21 & .225 & .624 & -.74 & .32 \\
\hline & IACBE & AACSB & .32 & .201 & .248 & -.15 & .80 \\
\hline & & ACBSP & .21 & .225 & .624 & -.32 & .74 \\
\hline
\end{tabular}


Table 84

Tukey's HSD Test of Multiple Comparisons Assessment

\begin{tabular}{|c|c|c|c|c|c|c|c|}
\hline \multirow[t]{2}{*}{ Dependent Variable } & \multirow[t]{2}{*}{ Accreditation } & \multirow[t]{2}{*}{ Accreditation } & \multirow[t]{2}{*}{$M_{\text {diff }}$} & \multirow[t]{2}{*}{$S E$} & \multirow[t]{2}{*}{$p$} & \multicolumn{2}{|c|}{ 95\% Confidence Interval } \\
\hline & & & & & & Lower Bound & Upper Bound \\
\hline \multirow[t]{6}{*}{$\begin{array}{l}\text { Faculty Resist } \\
\text { Assessment }\end{array}$} & AACSB & ACBSP & -.10 & .178 & .832 & -.52 & .32 \\
\hline & & IACBE & .31 & .190 & .226 & -.14 & .76 \\
\hline & ACBSP & AACSB & .10 & .178 & .832 & -.32 & .52 \\
\hline & & IACBE & .42 & .213 & .126 & -.09 & .92 \\
\hline & IACBE & AACSB & -.31 & .190 & .226 & -.76 & .14 \\
\hline & & ACBSP & -.42 & .213 & .126 & -.92 & .09 \\
\hline
\end{tabular}

Based on observed means.

* The mean difference is significant at the .05 level. 
Accreditation Commitment did not have a significant overall multivariate effect in accreditation commitment by accreditation agency however, the post hoc Tukey HSD test (see Table 82) and the univariate analysis (see Table 82) indicate a significant difference in unit faculty accreditation commitment between IACBE and ACBSP, where IACBE indicated a significantly higher faculty accreditation commitment compared to ACBSP. The means for unit administration commitment to accreditation were also very consistent across accreditation agencies and were very high $(4.83-4.89)$ which indicated strong agreement that the business unit administrations were committed to accreditation. AACSB had the highest mean response for the faculty being provided incentives but the means were all below 3 which indicated that units universally did not agree faculty were provided incentives (see Table 81). Although overall faculty do not appear to receive incentives, they do not seem to resist accreditation either as the means of all three accreditation agencies mean responses to faculty resistance were also in the range of disagree (2). 
Table 85

Means of Accreditation Commitment by Accreditation Agency

\begin{tabular}{|c|c|c|c|c|}
\hline & Accreditation & $M$ & $S D$ & $N$ \\
\hline \multirow{4}{*}{$\begin{array}{l}\text { Institution Administration } \\
\text { Accreditation Commitment }\end{array}$} & AACSB & 4.62 & .538 & 81 \\
\hline & ACBSP & 4.59 & .580 & 46 \\
\hline & IACBE & 4.76 & .548 & 37 \\
\hline & Total & 4.64 & .553 & 164 \\
\hline \multirow{4}{*}{$\begin{array}{l}\text { Unit Administration } \\
\text { Accreditation Commitment }\end{array}$} & AACSB & 4.89 & .316 & 81 \\
\hline & ACBSP & 4.83 & .383 & 46 \\
\hline & IACBE & 4.89 & .315 & 37 \\
\hline & Total & 4.87 & .335 & 164 \\
\hline \multirow{4}{*}{$\begin{array}{l}\text { Unit Faculty Accreditation } \\
\text { Commitment }\end{array}$} & AACSB & 4.40 & .719 & 81 \\
\hline & ACBSP & 4.09 & .865 & 46 \\
\hline & IACBE & 4.51 & .768 & 37 \\
\hline & Total & 4.34 & .785 & 164 \\
\hline \multirow{4}{*}{$\begin{array}{l}\text { Faculty Provided Incentive } \\
\text { Accreditation Commitment }\end{array}$} & AACSB & 2.80 & 1.249 & 81 \\
\hline & ACBSP & 2.54 & .982 & 46 \\
\hline & IACBE & 2.43 & 1.042 & 37 \\
\hline & Total & 2.65 & 1.139 & 164 \\
\hline \multirow{4}{*}{$\begin{array}{l}\text { Faculty Resistance } \\
\text { Accreditation Commitment }\end{array}$} & AACSB & 1.98 & .922 & 81 \\
\hline & ACBSP & 2.33 & .871 & 46 \\
\hline & IACBE & 2.00 & .882 & 37 \\
\hline & Total & 2.08 & .907 & 164 \\
\hline
\end{tabular}


Table 86

Accreditation Commitment Univariate Test Results

\begin{tabular}{|c|c|c|c|c|c|c|c|}
\hline \multicolumn{2}{|l|}{ Dependent Variable } & \multirow{2}{*}{$\begin{array}{r}S S \\
.676\end{array}$} & \multirow{2}{*}{$\frac{d f}{2}$} & \multirow{2}{*}{$\frac{M S}{.338}$} & \multirow{2}{*}{$\frac{F}{1.108}$} & \multirow{2}{*}{$\frac{p}{.333}$} & \multirow{2}{*}{$\frac{\eta^{2}}{.014}$} \\
\hline Institution Administration & Contrast & & & & & & \\
\hline Commitment & Error & 49.099 & 161 & .305 & & & \\
\hline \multirow{2}{*}{$\begin{array}{l}\text { Unit Administration } \\
\text { Accreditation } \\
\text { Commitment }\end{array}$} & Contrast & .135 & 2 & .067 & .597 & .552 & .007 \\
\hline & Error & 18.176 & 161 & .113 & & & \\
\hline \multirow{2}{*}{$\begin{array}{l}\text { Unit Faculty } \\
\text { Accreditation } \\
\text { Commitment }\end{array}$} & Contrast & 4.301 & 2 & 2.151 & 3.597 & .030 & .043 \\
\hline & Error & 96.253 & 161 & .598 & & & \\
\hline \multirow{2}{*}{$\begin{array}{l}\text { Faculty Provided } \\
\text { Incentive Accreditation } \\
\text { Commitment }\end{array}$} & Contrast & 4.154 & 2 & 2.077 & 1.613 & .203 & .020 \\
\hline & Error & 207.334 & 161 & 1.288 & & & \\
\hline \multirow{2}{*}{$\begin{array}{l}\text { Faculty Resistance } \\
\text { Accreditation } \\
\text { Commitment }\end{array}$} & Contrast & 3.910 & 2 & 1.955 & 2.420 & .092 & .029 \\
\hline & Error & 130.059 & 161 & .808 & & & \\
\hline
\end{tabular}

Note. The F tests the effect of Accreditation. This test is based on the linearly independent pairwise comparisons among the estimated marginal means.

Computed using alpha $=.05$ 
Table 87

Tukey's HSD Test of Multiple Comparisons Accreditation

\begin{tabular}{|c|c|c|c|c|c|c|c|}
\hline \multirow[t]{2}{*}{ Dependent Variable } & \multirow[t]{2}{*}{ Accreditation } & \multirow[t]{2}{*}{ Accreditation } & \multirow[t]{2}{*}{$M_{\text {diff }}$} & \multirow[t]{2}{*}{$S E$} & \multirow[t]{2}{*}{$p$} & \multicolumn{2}{|c|}{$95 \%$ Confidence Interval } \\
\hline & & & & & & Lower Bound & Upper Bound \\
\hline \multirow{7}{*}{$\begin{array}{l}\text { Institution } \\
\text { Administration } \\
\text { Accreditation } \\
\text { Commitment }\end{array}$} & AACSB & ACBSP & & & & & \\
\hline & & & .03 & .102 & .952 & -.21 & .27 \\
\hline & & IACBE & -.14 & .110 & .413 & -.40 & .12 \\
\hline & ACBSP & AACSB & -.03 & .102 & .952 & -.27 & .21 \\
\hline & & IACBE & -.17 & .122 & .347 & -.46 & .12 \\
\hline & IACBE & AACSB & .14 & .110 & .413 & -.12 & .40 \\
\hline & & ACBSP & .17 & .122 & .347 & -.12 & .46 \\
\hline \multirow{6}{*}{$\begin{array}{l}\text { Unit Administration } \\
\text { Accreditation } \\
\text { Commitment }\end{array}$} & AACSB & ACBSP & .06 & .062 & .570 & -.08 & .21 \\
\hline & & IACBE & .00 & .067 & .999 & -.16 & .15 \\
\hline & ACBSP & AACSB & -.06 & .062 & .570 & -.21 & .08 \\
\hline & & IACBE & -.07 & .074 & .649 & -.24 & .11 \\
\hline & IACBE & AACSB & .00 & .067 & .999 & -.15 & .16 \\
\hline & & ACBSP & .07 & .074 & .649 & -.11 & .24 \\
\hline
\end{tabular}


Table 88

Tukey's HSD Test of Multiple Comparisons Accreditation

\begin{tabular}{|c|c|c|c|c|c|c|c|}
\hline \multirow[t]{2}{*}{ Dependent Variable } & \multirow[t]{2}{*}{ Accreditation } & \multirow[t]{2}{*}{ Accreditation } & \multirow[t]{2}{*}{$M_{\text {diff }}$} & \multirow[t]{2}{*}{$S E$} & \multirow[t]{2}{*}{$p$} & \multicolumn{2}{|c|}{$95 \%$ Confidence Interval } \\
\hline & & & & & & Lower Bound & Upper Bound \\
\hline \multirow{7}{*}{$\begin{array}{l}\text { Unit Faculty } \\
\text { Accreditation } \\
\text { Commitment }\end{array}$} & AACSB & ACBSP & & & & & \\
\hline & & & .31 & .143 & .082 & -.03 & .65 \\
\hline & & IACBE & -.12 & .153 & .721 & -.48 & .24 \\
\hline & ACBSP & AACSB & -.31 & .143 & .082 & -.65 & .03 \\
\hline & & IACBE & $-.43^{*}$ & .171 & $.036 *$ & -.83 & -.02 \\
\hline & IACBE & AACSB & .12 & .153 & .721 & -.24 & .48 \\
\hline & & ACBSP & $.43 *$ & .171 & $.036 *$ & .02 & .83 \\
\hline \multirow{7}{*}{$\begin{array}{l}\text { Faculty Provided } \\
\text { Incentive for } \\
\text { Accreditation }\end{array}$} & AACSB & ACBSP & & & & & \\
\hline & & & .26 & .210 & .434 & -.24 & .75 \\
\hline & & IACBE & .37 & .225 & .231 & -.16 & .90 \\
\hline & ACBSP & AACSB & -.26 & .210 & .434 & -.75 & .24 \\
\hline & & IACBE & .11 & .251 & .898 & -.48 & .70 \\
\hline & IACBE & AACSB & -.37 & .225 & .231 & -.90 & .16 \\
\hline & & ACBSP & -.11 & .251 & .898 & -.70 & .48 \\
\hline
\end{tabular}


Table 89

Tukey's HSD Test of Multiple Comparisons Accreditation

\begin{tabular}{|c|c|c|c|c|c|c|c|}
\hline \multirow[t]{2}{*}{ Dependent Variable } & \multirow[t]{2}{*}{ Accreditation } & \multirow[t]{2}{*}{ Accreditation } & \multirow[t]{2}{*}{$M_{\text {diff }}$} & \multirow[t]{2}{*}{$S E$} & \multirow[t]{2}{*}{$p$} & \multicolumn{2}{|c|}{ 95\% Confidence Interval } \\
\hline & & & & & & Lower Bound & Upper Bound \\
\hline \multirow{6}{*}{$\begin{array}{l}\text { Faculty Resist } \\
\text { Accreditation }\end{array}$} & AACSB & ACBSP & -.35 & .166 & .090 & -.74 & .04 \\
\hline & & IACBE & -.02 & .178 & .989 & -.45 & .40 \\
\hline & ACBSP & AACSB & .35 & .166 & .090 & -.04 & .74 \\
\hline & & IACBE & .33 & .198 & .231 & -.14 & .80 \\
\hline & IACBE & AACSB & .02 & .178 & .989 & -.40 & .45 \\
\hline & & ACBSP & -.33 & .198 & .231 & -.80 & .14 \\
\hline
\end{tabular}

Based on observed means.

* The mean difference is significant at the .05 level 
A statistically significant model was found for responses to questions concerning what influenced assessment plan revisions ( Wilks' $\Lambda=.981, F=2.207, d f=(8,296), p=.027, \eta^{2}=$ .056). Upon closer examination, the significant difference was found for IACBE and AACSB. IACBE accredited units indicated that they used institution recommendations as the basis for revisions significantly more than AACSB, both in the Tukey HSD test (see Table 92) and the univariate test (see Table 91). No statistically significant differences were found between accreditation agencies based on revisions based on the accreditation agency, experiences, and results.

Table 90

Means of Revision Influences by Accreditation Agency

\begin{tabular}{lcccc}
\hline & Accreditation & $M$ & $S D$ & $N$ \\
\hline Specialized Accreditation & AACSB & 2.84 & 1.136 & 77 \\
Recommendations & ACBSP & 3.02 & 1.123 & 43 \\
& IACBE & 3.29 & .760 & 34 \\
& Total & 2.99 & 1.069 & 154 \\
Institution Recommendations & AACSB & 2.29 & .958 & 77 \\
& ACBSP & 2.65 & 1.131 & 43 \\
& IACBE & 3.12 & 1.038 & 34 \\
& Total & 2.57 & 1.072 & 154 \\
Business School Faculty & AACSB & 3.16 & .974 & 77 \\
& ACBSP & 3.05 & 1.090 & 43 \\
& IACBE & 3.38 & .985 & 34 \\
& Total & 3.18 & 1.011 & 154 \\
& AACSB & 3.23 & 1.025 & 77 \\
& ACBSP & 3.23 & .922 & 43 \\
& IACBE & 3.59 & .783 & 34 \\
& & 3.31 & .953 & 154 \\
\hline & & & &
\end{tabular}


Table 91

Revision Influence Univariate Test Results

\begin{tabular}{llrrrrrr} 
Dependent Variable & & $S S$ & $d f$ & $M S$ & $F$ & $p$ & $\eta^{2}$ \\
\hline $\begin{array}{l}\text { Specialized Accreditation } \\
\text { Recommendations }\end{array}$ & Contrast & 4.828 & 2 & 2.414 & 2.142 & .121 & .028 \\
& Error & 170.165 & 151 & 1.127 & & & \\
Institution & Contrast & 16.703 & 2 & 8.352 & 7.931 & .001 & .095 \\
Recommendations & Error & 159.011 & 151 & 1.053 & & & \\
& & & & & & \\
Business School Faculty & Contrast & 2.200 & 2 & 1.100 & 1.078 & .343 & .014 \\
& Error & 154.066 & 151 & 1.020 & & & \\
Assessment Findings & Contrast & 3.337 & 2 & 1.669 & 1.857 & .160 & .024 \\
& Error & 135.702 & 151 & .899 & & & \\
\hline
\end{tabular}

Note. The F tests the effect of Accreditation. This test is based on the linearly independent pairwise comparisons among the estimated marginal means.

Computed using alpha $=.05$ 
Table 92

Tukey's HSD Test of Multiple Comparisons Revision

\begin{tabular}{|c|c|c|c|c|c|c|c|}
\hline \multirow[t]{2}{*}{ Dependent Variable } & \multirow[t]{2}{*}{ Accreditation } & \multirow[t]{2}{*}{ Accreditation } & \multirow[t]{2}{*}{$M_{\text {diff }}$} & \multirow[t]{2}{*}{$S E$} & \multirow[t]{2}{*}{$p$} & \multicolumn{2}{|c|}{ 95\% Confidence Interval } \\
\hline & & & & & & Lower Bound & Upper Bound \\
\hline \multirow{6}{*}{$\begin{array}{l}\text { Specialized } \\
\text { Accreditation } \\
\text { Recommendations }\end{array}$} & AACSB & ACBSP & -.18 & .202 & .650 & -.66 & .30 \\
\hline & & IACBE & -.45 & .219 & .102 & -.97 & .07 \\
\hline & ACBSP & AACSB & .18 & .202 & .650 & -.30 & .66 \\
\hline & & IACBE & -.27 & .244 & .508 & -.85 & .31 \\
\hline & IACBE & AACSB & .45 & .219 & .102 & -.07 & .97 \\
\hline & & ACBSP & .27 & .244 & .508 & -.31 & .85 \\
\hline \multirow[t]{6}{*}{$\begin{array}{l}\text { Institution } \\
\text { Recommendations }\end{array}$} & AACSB & ACBSP & -.37 & .195 & .151 & -.83 & .10 \\
\hline & & IACBE & $-.83 *$ & .211 & $.000 *$ & -1.33 & -.33 \\
\hline & ACBSP & AACSB & .37 & .195 & .151 & -.10 & .83 \\
\hline & & IACBE & -.47 & .236 & .120 & -1.02 & .09 \\
\hline & IACBE & AACSB & $.83^{*}$ & .211 & $.000^{*}$ & .33 & 1.33 \\
\hline & & ACBSP & .47 & .236 & .120 & -.09 & 1.02 \\
\hline
\end{tabular}


Table 93

Tukey's HSD Test of Multiple Comparisons Revision

\begin{tabular}{|c|c|c|c|c|c|c|c|}
\hline \multirow[t]{2}{*}{ Dependent Variable } & \multirow[t]{2}{*}{ Accreditation } & \multirow[t]{2}{*}{ Accreditation } & \multirow[t]{2}{*}{$M_{\text {diff }}$} & \multirow[t]{2}{*}{$S E$} & \multirow[t]{2}{*}{$p$} & \multicolumn{2}{|c|}{ 95\% Confidence Interval } \\
\hline & & & & & & Lower Bound & Upper Bound \\
\hline \multirow{6}{*}{$\begin{array}{l}\text { Business School } \\
\text { Faculty } \\
\text { Recommendations }\end{array}$} & AACSB & ACBSP & .11 & .192 & .837 & -.35 & .56 \\
\hline & & IACBE & -.23 & .208 & .522 & -.72 & .27 \\
\hline & ACBSP & AACSB & -.11 & .192 & .837 & -.56 & .35 \\
\hline & & IACBE & -.34 & .232 & .319 & -.88 & .21 \\
\hline & IACBE & AACSB & .23 & .208 & .522 & -.27 & .72 \\
\hline & & ACBSP & .34 & .232 & .319 & -.21 & .88 \\
\hline \multirow[t]{6}{*}{$\begin{array}{l}\text { Assessment } \\
\text { Findings }\end{array}$} & AACSB & ACBSP & .00 & .180 & 1.000 & -.43 & .43 \\
\hline & & IACBE & -.35 & .195 & .168 & -.82 & .11 \\
\hline & ACBSP & AACSB & .00 & .180 & 1.000 & -.43 & .43 \\
\hline & & IACBE & -.36 & .218 & .234 & -.87 & .16 \\
\hline & IACBE & AACSB & .35 & .195 & .168 & -.11 & .82 \\
\hline & & ACBSP & .36 & .218 & .234 & -.16 & .87 \\
\hline
\end{tabular}

Based on observed means.

* The mean difference is significant at the .05 level. 
Although no significant model was found for success factors overall in the MANOVA calculation, the univariate analysis (see Table 88) and Tukey HSD test (see Table 97) found significant differences. The univariate analysis had significant differences in the extent which assessment efforts influence students' ability to secure internships, graduation rates, the graduates' ability to obtain a job, the graduates' skills and job performance, and as a basis for updating curriculum. Tukey's HSD also had significant differences in graduation rates, the graduates' ability to obtain a job, the graduates' skills and job performance, and as a basis for updating curriculum but did not have a significant effect for the students' ability to obtain internships. All the significant differences were found between IACBE and AACSB. The IACBE factors were all higher than the AACSB values. The highest mean for all the questions in this category was the degree which assessment efforts improve the units' ability to achieve and/or sustain accreditation (see Table 94). Unit means by accreditation agency affiliation were all at a level above agreement and heading toward strongly agreeing that assessment improved the unit's ability to achieve or sustain accreditation.

Table 94

Means of Success Factors by Accreditation Agency

\begin{tabular}{lcccc}
\hline & Accreditation & $M$ & $S D$ & $N$ \\
\hline Passing Grades & AACSB & 2.67 & .918 & 69 \\
& ACBSP & 2.89 & 1.120 & 46 \\
Secure Internships & IACBE & 3.16 & .934 & 31 \\
& Total & 2.84 & 1.001 & 146 \\
& AACSB & 2.48 & .949 & 69 \\
& ACBSP & 2.93 & 1.124 & 46 \\
& IACBE & 2.94 & 1.031 & 31 \\
& Total & 2.72 & 1.042 & 146 \\
\hline
\end{tabular}

Table 95 Continued 
Means of Success Factors by Accreditation Agency

\begin{tabular}{|c|c|c|c|c|}
\hline & Accreditation & $M$ & $S D$ & $N$ \\
\hline \multirow[t]{4}{*}{ Graduation Rates } & AACSB & 2.67 & .902 & 69 \\
\hline & ACBSP & 2.85 & 1.053 & 46 \\
\hline & IACBE & 3.19 & .833 & 31 \\
\hline & Total & 2.84 & .954 & 146 \\
\hline \multirow[t]{4}{*}{$\begin{array}{l}\text { Graduates Ability to Obtain } \\
\text { Job }\end{array}$} & AACSB & 2.78 & .905 & 69 \\
\hline & ACBSP & 3.15 & 1.135 & 46 \\
\hline & IACBE & 3.35 & .950 & 31 \\
\hline & Total & 3.02 & 1.013 & 146 \\
\hline \multirow[t]{4}{*}{$\begin{array}{l}\text { Graduate Skills and Job } \\
\text { Performance }\end{array}$} & $\mathrm{AACSB}$ & 3.16 & .933 & 69 \\
\hline & ACBSP & 3.20 & 1.128 & 46 \\
\hline & IACBE & 3.74 & .773 & 31 \\
\hline & Total & 3.29 & .991 & 146 \\
\hline \multirow[t]{4}{*}{ Update Curriculum } & AACSB & 3.86 & .845 & 69 \\
\hline & ACBSP & 3.96 & .942 & 46 \\
\hline & IACBE & 4.32 & .653 & 31 \\
\hline & Total & 3.99 & .855 & 146 \\
\hline \multirow[t]{4}{*}{$\begin{array}{l}\text { Achieve/Sustain } \\
\text { Accreditation }\end{array}$} & AACSB & 4.25 & .898 & 69 \\
\hline & ACBSP & 4.24 & .848 & 46 \\
\hline & IACBE & 4.52 & .508 & 31 \\
\hline & Total & 4.30 & .817 & 146 \\
\hline \multirow[t]{4}{*}{ Quality and Success of Unit } & $\mathrm{AACSB}$ & 3.84 & .816 & 69 \\
\hline & ACBSP & 4.04 & .918 & 46 \\
\hline & IACBE & 4.16 & .735 & 31 \\
\hline & Total & 3.97 & .838 & 146 \\
\hline
\end{tabular}


Table 96

Success Factors Univariate Test Results

\begin{tabular}{|c|c|c|c|c|c|c|c|}
\hline Dependent Variable & & $S S$ & $d f$ & $M S$ & $F$ & $P$ & $\eta^{2}$ \\
\hline \multirow[t]{2}{*}{ Passing Grades } & Contrast & 5.393 & 2 & 2.697 & 2.755 & .067 & .037 \\
\hline & Error & 139.983 & 143 & .979 & & & \\
\hline \multirow[t]{2}{*}{ Secure Internships } & Contrast & 7.594 & 2 & 3.797 & 3.622 & $.029 *$ & .048 \\
\hline & Error & 149.893 & 143 & 1.048 & & & \\
\hline \multirow[t]{2}{*}{ Graduation Rates } & Contrast & 5.948 & 2 & 2.974 & 3.372 & $.037 *$ & .045 \\
\hline & Error & 126.107 & 143 & .882 & & & \\
\hline \multirow[t]{2}{*}{$\begin{array}{l}\text { Graduates Ability to } \\
\text { Obtain Job }\end{array}$} & Contrast & 8.168 & 2 & 4.084 & 4.149 & $.018 *$ & .055 \\
\hline & Error & 140.771 & 143 & .984 & & & \\
\hline \multirow{2}{*}{$\begin{array}{l}\text { Graduate Skills and } \\
\text { Job Performance }\end{array}$} & Contrast & 7.915 & 2 & 3.957 & 4.210 & $.017 *$ & .056 \\
\hline & Error & 134.421 & 143 & .940 & & & \\
\hline \multirow[t]{2}{*}{ Update Curriculum } & Contrast & 4.735 & 2 & 2.367 & 3.344 & $.038 *$ & .045 \\
\hline & Error & 101.238 & 143 & .708 & & & \\
\hline \multirow[t]{2}{*}{$\begin{array}{l}\text { Achieve/Sustain } \\
\text { Accreditation }\end{array}$} & Contrast & 1.817 & 2 & .908 & 1.368 & .258 & .019 \\
\hline & Error & 94.923 & 143 & .664 & & & \\
\hline \multirow[t]{2}{*}{$\begin{array}{l}\text { Quality and Success of } \\
\text { Unit }\end{array}$} & Contrast & 2.537 & 2 & 1.269 & 1.826 & .165 & .025 \\
\hline & Error & 99.353 & 143 & .695 & & & \\
\hline
\end{tabular}


Table 97

Tukey's HSD Test of Multiple Comparisons Success

\begin{tabular}{|c|c|c|c|c|c|c|c|}
\hline \multirow[t]{2}{*}{$\begin{array}{l}\text { Dependent } \\
\text { Variable }\end{array}$} & \multirow[t]{2}{*}{ Accreditation } & \multirow[t]{2}{*}{ Accreditation } & \multirow[t]{2}{*}{$M_{\text {diff }}$} & \multirow[t]{2}{*}{$S E$} & \multirow[t]{2}{*}{$p$} & \multicolumn{2}{|c|}{ 95\% Confidence Interval } \\
\hline & & & & & & Lower Bound & Upper Bound \\
\hline \multirow[t]{6}{*}{ Passing Grades } & AACSB & ACBSP & -.22 & .188 & .459 & -.67 & .22 \\
\hline & & IACBE & -.49 & .214 & .057 & -1.00 & .01 \\
\hline & ACBSP & AACSB & .22 & .188 & .459 & -.22 & .67 \\
\hline & & IACBE & -.27 & .230 & .470 & -.81 & .27 \\
\hline & IACBE & AACSB & .49 & .214 & .057 & -.01 & 1.00 \\
\hline & & ACBSP & .27 & .230 & .470 & -.27 & .81 \\
\hline \multirow[t]{6}{*}{ Secure Internships } & AACSB & ACBSP & -.46 & .195 & .053 & -.92 & .01 \\
\hline & & IACBE & -.46 & .221 & .101 & -.98 & .07 \\
\hline & ACBSP & AACSB & .46 & .195 & .053 & -.01 & .92 \\
\hline & & IACBE & .00 & .238 & 1.000 & -.56 & .56 \\
\hline & IACBE & AACSB & .46 & .221 & .101 & -.07 & .98 \\
\hline & & ACBSP & .00 & .238 & 1.000 & -.56 & .56 \\
\hline
\end{tabular}


Table 98 Continued

Tukey's HSD Test of Multiple Comparisons Success

\begin{tabular}{|c|c|c|c|c|c|c|c|}
\hline \multirow[t]{2}{*}{$\begin{array}{l}\text { Dependent } \\
\text { Variable }\end{array}$} & \multirow[t]{2}{*}{ Accreditation } & \multirow[t]{2}{*}{ Accreditation } & \multirow[t]{2}{*}{$M_{\text {diff }}$} & \multirow[t]{2}{*}{$S E$} & \multirow[t]{2}{*}{$p$} & \multicolumn{2}{|c|}{ 95\% Confidence Interval } \\
\hline & & & & & & Lower Bound & Upper Bound \\
\hline \multirow[t]{6}{*}{ Graduation Rates } & AACSB & ACBSP & -.18 & .179 & .570 & -.60 & .24 \\
\hline & & IACBE & $-.53 *$ & .203 & $.028^{*}$ & -1.01 & -.05 \\
\hline & ACBSP & AACSB & .18 & .179 & .570 & -.24 & .60 \\
\hline & & IACBE & -.35 & .218 & .256 & -.86 & .17 \\
\hline & IACBE & AACSB & $.53^{*}$ & .203 & $.028^{*}$ & .05 & 1.01 \\
\hline & & ACBSP & .35 & .218 & .256 & -.17 & .86 \\
\hline \multirow[t]{6}{*}{$\begin{array}{l}\text { Graduates Ability } \\
\text { to Obtain Job }\end{array}$} & AACSB & ACBSP & -.37 & .189 & .127 & -.82 & .08 \\
\hline & & IACBE & $-.57 *$ & .215 & $.023^{*}$ & -1.08 & -.06 \\
\hline & ACBSP & AACSB & .37 & .189 & .127 & -.08 & .82 \\
\hline & & IACBE & -.20 & .231 & .654 & -.75 & .34 \\
\hline & IACBE & AACSB & $.57 *$ & .215 & $.023 *$ & .06 & 1.08 \\
\hline & & ACBSP & .20 & .231 & .654 & -.34 & .75 \\
\hline
\end{tabular}


Table 99 Continued

Tukey's HSD Test of Multiple Comparisons Success

\begin{tabular}{|c|c|c|c|c|c|c|c|}
\hline \multirow[t]{2}{*}{$\begin{array}{l}\text { Dependent } \\
\text { Variable }\end{array}$} & \multirow[t]{2}{*}{ Accreditation } & \multirow[t]{2}{*}{ Accredication } & \multirow[t]{2}{*}{$M_{\text {diff }}$} & \multirow[t]{2}{*}{$S E$} & \multirow[t]{2}{*}{$p$} & \multicolumn{2}{|c|}{ 95\% Confidence Interval } \\
\hline & & & & & & Lower Bound & Upper Bound \\
\hline \multirow{6}{*}{$\begin{array}{l}\text { Graduate Skills } \\
\text { and Job } \\
\text { Performance }\end{array}$} & AACSB & ACBSP & -.04 & .185 & .979 & -.47 & .40 \\
\hline & & IACBE & $-.58 *$ & .210 & $.017 *$ & -1.08 & -.09 \\
\hline & ACBSP & AACSB & .04 & .185 & .979 & -.40 & .47 \\
\hline & & IACBE & $-.55 *$ & .225 & $.043 *$ & -1.08 & -.01 \\
\hline & IACBE & AACSB & $.58^{*}$ & .210 & $.017 *$ & .09 & 1.08 \\
\hline & & ACBSP & $.55^{*}$ & .225 & $.043 *$ & .01 & 1.08 \\
\hline \multirow[t]{6}{*}{$\begin{array}{l}\text { Update } \\
\text { Curriculum }\end{array}$} & AACSB & ACBSP & -.10 & .160 & .802 & -.48 & .28 \\
\hline & & IACBE & $-.47 *$ & .182 & $.030 *$ & -.90 & -.04 \\
\hline & ACBSP & AACSB & .10 & .160 & .802 & -.28 & .48 \\
\hline & & IACBE & -.37 & .196 & .151 & -.83 & .10 \\
\hline & IACBE & AACSB & $.47 *$ & .182 & $.030 *$ & .04 & .90 \\
\hline & & ACBSP & .37 & .196 & .151 & -.10 & .83 \\
\hline
\end{tabular}


Table 100 Continued

Tukey's HSD Test of Multiple Comparisons Success

\begin{tabular}{|c|c|c|c|c|c|c|c|}
\hline \multirow[t]{2}{*}{$\begin{array}{l}\text { Dependent } \\
\text { Variable }\end{array}$} & \multirow[t]{2}{*}{ Accreditation } & \multirow[t]{2}{*}{ Accredication } & \multirow[t]{2}{*}{$M_{\text {diff }}$} & \multirow[t]{2}{*}{$S E$} & \multirow[t]{2}{*}{$p$} & \multicolumn{2}{|c|}{ 95\% Confidence Interval } \\
\hline & & & & & & Lower Bound & Upper Bound \\
\hline \multirow[t]{6}{*}{$\begin{array}{l}\text { Achieve/Sustain } \\
\text { Accreditation }\end{array}$} & AACSB & ACBSP & .01 & .155 & .999 & -.36 & .37 \\
\hline & & IACBE & -.27 & .176 & .279 & -.69 & .15 \\
\hline & ACBSP & AACSB & -.01 & .155 & .999 & -.37 & .36 \\
\hline & & IACBE & -.28 & .189 & .312 & -.73 & .17 \\
\hline & IACBE & AACSB & .27 & .176 & .279 & -.15 & .69 \\
\hline & & ACBSP & .28 & .189 & .312 & -.17 & .73 \\
\hline \multirow[t]{6}{*}{$\begin{array}{l}\text { Quality and } \\
\text { Success of Unit }\end{array}$} & AACSB & ACBSP & -.20 & .159 & .409 & -.58 & .17 \\
\hline & & IACBE & -.32 & .180 & .180 & -.75 & .11 \\
\hline & ACBSP & AACSB & .20 & .159 & .409 & -.17 & .58 \\
\hline & & IACBE & -.12 & .194 & .816 & -.58 & .34 \\
\hline & IACBE & AACSB & .32 & .180 & .180 & -.11 & .75 \\
\hline & & ACBSP & .12 & .194 & .816 & -.34 & .58 \\
\hline
\end{tabular}

Based on observed means.

* The mean difference is significant at the .05 level. 


\section{Summary}

This chapter explained the details of the research results. First, the responses to the survey mailings were explained, and then the demographic analysis provided details concerning the study participants and their institution and unit information. Results were then presented by research question including an analysis of the data gathered. The first research question found that overall accredited business units are following the best practices in assessment at a moderate to high level. Specifically, business units seem to begin assessment with educational values, have clearly stated purposes, assess in an ongoing manner, and focus assessment on issues of use and importance. The second research question looked for correlations in assessment activities with the success of business schools. A positive correlation was found in items that were related to the success of students and graduates. The strongest correlations were found in updating the curriculum and Principles 3, 5, and 7 (all of which were found to be principles of best practice that were followed in research question 1). The quality and success of the unit also had strong correlations with Principles 5 and 7. The third research question examined significant differences in outcomes assessment practices by IACBE, ACBSP, and AACSB accreditations. Significant differences were found between units with different specialized business accreditation. In most instances, the statistically significant difference involved IACBE and AACSB; however, there were also instances of IACBE and ACBSP and ACBSP and AACSB having statistically significant differences. This question also examined the contribution of assessment to the success of the business unit and found it to be a positive influence. 


\section{CHAPTER 5: SUMMARY, CONCLUSIONS, RECOMMENDATIONS FOR PRACTICE AND RECOMMENDATIONS FOR RESEARCH}

\section{Discussion}

The previous chapters provided an understanding of assessment, accreditation, and the state of each in accredited undergraduate business schools in the United States. Very little research has looked at the accreditation of business schools in a comprehensive manner and data found from this study was rich and provided basis for an understanding of business school assessment efforts and detailed information on accreditation agencies. The purpose of this study was to determine the degree accredited business schools follow the best practices in assessment and identify the relationship of assessment to the success of a business school. This study also explored the potential differences in assessment standards and practices among the three business unit specialized accrediting bodies.

The total number of usable survey responses returned was 203. As would be expected, since it has been in existence the longest, the largest representative group returning the survey was AACSB, which accounted for just over $40 \%$ of the surveys returned $(N=81)$. AACSB accredited units also tended to be from larger schools. The study percentages of public and private institutions are slightly different than the national number of institutions awarding business degrees. In the 2005/2006 academic year, there were 2,214 bachelor-level degree granting institution, 602 public and 1,612 private. Of those 2,214 institutions, 1,697 granted business degrees. There were 547 public institutions and 1,150 private institutions (U.S. Department of Education, 2008). The number of survey respondents from public institutions was greater than from private institutions. This deviation from national statistics was even stronger in the large number of public AACSB responding institutions (53) compared to private institutions 
(20). Potential reasons for this difference may include the age of the institutions (many AACSB institutions are older, established institutions), the push toward state standards and accountability of state-supported institutions, and other related justifications. Teaching-focused units were the largest group making up over $80 \%$ of the respondents. It is interesting to note that all of the institutions that were identified as primarily research-focused were AACSB accredited (13 AACSB only and 1 unit with multiple specialized accreditations, which included AACSB). AACSB accredited institutions also had a larger mean student population and much larger faculty than the AACSB and IACBE institutions.

Survey respondents generally indicated a high level of assessment activity and only one institution indicated that they did not have an assessment plan and no any intention of creating one. Only 24 institutions indicated that their assessment plans were not mature enough to review results. AACSB, although having the smallest percentage of units without results to review, was also the institution with the smallest percentage of units that were at full maturity with respect to their assessment plan (reviewing the assessment plan and making changes to the plan). Again, this may be due to the larger size of the units and the additional management activities that are involved in larger scale projects. As expected, the specialized accreditation details and handbooks were instrumental in the development of the assessment plans.

Principle 1 of the AAHE Principles of Good Practice of Assessment indicates that assessment of student learning begins with educational values. The mission statement of the institution and the unit provide the basis and starting point for assessment (Banta, Lund, Black, $\&$ Oblander, 1996). The results of the analysis showed that both the institution and unit missions were reflected in the stated outcomes and assessments of their respective areas. Given that the 
assessments in question for this study were related to the units, the strong connection to the unit mission $(M=4.46, S D=.720)$ is a very positive indicator that units are practicing this principle.

Principle 2 is concerned with the assessments reflecting learning as multidimensional, integrated, and revealed in performance over time. One area of this multidimensionality is the use of direct and indirect assessments. All three accreditation agencies recommend the use of these types of assessments and give examples. To better analyze this principle, these two areas were broken into separate research areas and this provided insight into the use of this type of assessment by accredited business schools. Direct assessments were found to be utilized more often than indirect assessments. Rationale to explain this difference could include the relative ease of administering and interpreting direct academic assessment compared to indirect assessments. Written assessments were found to be the most common direct assessment, which is not surprising considering that all three accreditation agencies explicitly mention projects and exams as potential methods in their standards (AACSB, 2005, ACBSP, 2004b, IACBS, 2005). Overall, the units indicated that they used multiple methods of assessment, assessed students at multiple points, and in a fashion that was integrated across business curriculum at a level of frequently or very frequently. Less than two thirds of the units indicated that they use rubrics frequently or very frequently. This is not surprising as assessment is not typically used as a tool to show learners how their work compares to a standard (Huba \& Freed, 2000). It is hopeful that the business units will increase the use of these instruments as it was of great importance to the expert panel and it also provides the level of feedback to students so that they are able to understand their work and how to improve it.

The next principle, Principle 3 , was concerned with the assessment having clear explicitly stated purpose. It is important for the assessment plan to indicate why the assessment is being 
conducted so that everyone understands the importance of the actions. Assessments that are completed solely to meet a mandate (accreditation or otherwise) will not survive long enough to produce lasting effects unless it becomes connected to another valued process (Banta, 2002). This principle had a mean value of 4.04. One improvement in this area could include revising the business unit assessment plan so that it explicitly stated objective measures. Another possibility for improvement would be clearly stating the goals of individual assessments. Over one fourth of the respondents indicated that they were either neutral or did not agree that these two areas were met in their units.

Principle 4 ensures that attention is paid to outcomes but is also concerned with the student experiences and ensuring that they are also considered. Over half of the survey respondents indicated that they considered student experiences. This is a similar finding to a previous study of business faculty (Michlitsch \& Sidle, 2002). Improvements in this area would be to encourage the consideration of teaching styles when developing assessments as over a quarter of the respondents indicated that they failed to do so.

Principle 5 is that assessment is ongoing, not episodic. As shown previously, assessment is a process. Over $85 \%$ of the accredited undergraduate business units reported that assessment was an ongoing continuous improvement process. This finding is much higher than the $58 \%$ finding in a recent study of Accounting programs (Lusher, 2006). Overall, responses in this area indicate that assessment is ongoing and is a continuous improvement process.

Involvement of representatives across the educational community is the focus of Principle 6. Approximately $15 \%$ of the units indicated that the whole faculty did not participate in assessment (it was an individual effort) and that individuals from outside of the campus community are not included in the assessment process. Approximately another 20 to $25 \%$ were 
neutral. Obvious improvements in this area would be to involve all faculty in assessment. This could be accomplished at department meetings, faculty retreats or workshops, forums, or other group meetings. If meeting time is a problem, as many faculty have full schedules, perhaps having an online review and input process available to record individual comments and suggestions, then providing summative group feedback would be a good place to start. It is also important to ensure that the business unit is part of any cross-discipline teams that are reviewing curriculum. This multi-content team could provide significant insight to business and general studies curriculums. Another opportunity for improving the feedback and participation of the education community would be to increase the use of outside stakeholders by holding focus groups, conducting surveys, meeting with advisory boards, or other methods.

Principle 7 states that assessment makes a difference when it begins with issues of use and illustrates questions that people really care about. As expressed earlier, accreditation is a means of providing an answer to the important quality question (based on stated external standards). Overall, the units agreed that assessments are focused on improving student knowledge, measured items are relevant and important to unit decisions, and that results are shared with faculty. One area that could be improved was the focus on learners in outcomes as, although most units agreed, nearly one fifth were neutral when asked if their outcomes were learner - centered. As teaching shifts from teacher-centered to learner-centered, the outcomes should also shift from the content covered to the learner's obtained knowledge. While faculty and departments may still use assessment to monitor the learning process, it should also be used to enhance the learning and focus on the student's learning as a process.

Principle 8 indicates that assessment is most likely to lead to improvement when it is part of a larger set of conditions that promote change. This principle had the lowest mean of all 9 
principles (although still above 3 as a whole). The reason for this lower number seemed to result primarily in the fact that over half of the units indicated that faculty are not provided incentives to participate in assessment. In fact, only $15.8 \%$ indicated that they agree faculty are provided incentives (the remaining $22.2 \%$ were neutral). In contrast, assessment does seem to be part of the strategic plan and is part of internal program review. Over half of the units indicated that assessment was part of their culture. Obviously, offering faculty incentives to participate in assessment would improve the level that business units meet this principle.

The final principle, Principle 9, is concerned with the meeting responsibilities to the students and public. Part of this culture is the communication of results to learners and the public. This area was not found to be a strength of the units. Over half indicated that their unit results were not communicated with the public, and nearly that many reported that they were not shared with students. Although over half agreed that learners were informed of the outcomes, over one third were neutral or disagreed with that as well. Pike (2002) states that "it appears that communicating assessment results, in and of itself, impels action on assessment” (p. 144). As the call for accountability increases, and the economic state of the US declines, business units need to focus on showcasing their assessment results. It is easy to convince business units to share their positive results; however, it is also important that they show any deficiencies and the action steps that have been taken or are planned. If a business unit is working proactively to improve their department, the responsiveness and student-centered nature of those actions will overcome any negative images invoked by poor results.

Assessment practices in accredited business units appears to be in relatively good health. The 9 principles were met with a level of 3 and 4 on a 5-point scale. The lowest mean was 3.39 
and the highest was 4.37 which indicates a moderate to high level of the best assessment practices.

The second research question related to the impact assessment activities had on the success of the business schools. In general, the assessment activities had positive correlations with the success factors identified in the study. The unit responses indicated a stronger perceived impact on those items that had a direct impact on the unit, rather than the students or graduates. In fact, the highest mean response was to the question that asked about assessment's impact on the unit's ability to achieve or sustain accreditation. The correlation of the success factors to the 9 Principles indicated that following good assessment practices was likely to lead to successful students, graduates, and units. All of the correlations were positive and, with the exception of the specific direct and indirect question sets, they were statistically significant at the .01 level. The direct and indirect measures were not found to be significant with the unit success factors (although updating curriculum was significant at the .05 level).

The final research question investigated the differences in outcomes assessment practices by accreditation body. This question was analyzed using multivariate analysis which was at times not as robust as it could have been due to the different group sizes; however, many meaningful results were found (both multivariate and univariate). At the multivariate level, there were significant differences by accreditation body in Principle 1, Principle 2, and Principle 9. This indicates that overall, there is a difference in the way accredited business units use the unit and institution goals and educational values as a starting point for creating outcomes and assessments; there is a difference in the assessment and the ongoing nature of the learning process; and, there is a difference in the level which educators use assessment to meet responsibilities to students and to the public. 
In addition, the univariate analysis found significant differences in Principle 3, Principle 5, Principle 6, and Principle 8. These differences indicate that there are some factors of the principles that differ in the units by specialized accreditation. Specifically, there are differences in the level that programs have clear, explicitly stated purposes; the level that assessment is an ongoing process; the level that representatives from across the educational community are involved; and, the level that assessment is part of a larger set of conditions that promote change. In general, the majority of the differences were between IACBE and AACSB; however, there were also significant differences in IACBE and ACBSP and ACBSP and AACSB. No differences by accreditation agency were noted for Principle 4, Assessment requires attention to outcomes but also and equally to the experiences that lead to those outcomes, and Principle 7 Assessment makes a difference when it begins with issues of use and illustrates questions that people really care about.

Commitment to Assessment was found to be significant in the multivariate test and both Assessment and Accreditation were found to have significant univariate models by accreditation agency. IACBE accredited units indicated that their business unit faculty had a stronger commitment to assessment compared to AACSB accredited units. Influences on the revision of the assessment plan was found to have a statistically significant difference by accreditation agency in the multivariate analysis. IACBE accredited units indicated that they made changes to their assessment plan more frequently than AACSB accredited units. Although no significant model was found in the multivariate test for success factors, the univariate test and the Tukey HSD test found significant differences by accreditation body. In each case, IACBE reported that assessment contributed to success at a higher level compared to AACSB accredited business units. 


\section{Recommendations}

Based on the results of the study, some recommendations can be made for improving business units in the US and the research concerning accredited business units. The first group of recommendations include practical recommendations for business units to improve the level at which they practice the principles of best practice in assessment. Following those recommendations, some additional research suggestions are made to facilitate a more comprehensive, in-depth understanding of assessment in business units.

\section{For Practice}

There were areas identified by the research that should be addressed by business units. Specifically, faculty should be provided incentives to participate in assessment and accreditation activities. Although the administrative units are committed to assessment and accreditation, and have made it part of the strategic plan, they do not provide the necessary incentives to increase the faculty participation and create a culture of assessment. The use of assessment has the potential to significantly improve the programs and unit, given the positive correlation between assessment and the success of the business unit.

The use of computer resources in business units could be improved to assess, manage, and maintain assessment data. The most common application, spreadsheets, is very limited in ability to maintain assessment data, only providing opportunity to store quantitative data. As reporting requirements and time demands to produce reports increase, the use of automation would improve the efficiency of the unit. For example, business units could use an assessment management database to enter assessment data and provide reporting to stakeholders. Many of the vendors of such packages present their packages at accreditation conferences and conventions. Finding a software solution that matches the needs of the business unit will 
facilitate assessment data collection and ease the burden of reporting. There are also software packages that allow the analysis of data. These include many publisher-produced databases and simulations that can be, or have already been, mapped to assessment outcomes and accreditation standards.

Communication should be improved with internal and external constituents. Using feedback from stakeholders can improve the program significantly. Current students can provide feedback on the assessments that they have completed to help modify them for future use and completed student evaluation forms (of classes) can be revised to identify the level that assessment activities contribute to the department or degree objectives. As graduates, students can provide feedback on how they have used the knowledge, skills, and abilities that they gained in the business unit and how to improve those (content, experiences, etc.).

Rubrics should be used more often to allow students to grow and learn from the assessment process. Rubrics provide parameters for students so that they understand levels of achievement used to classify their performance. Having rubrics before they complete the assignment or activity provides students with target behaviors to practice or to work towards. Additionally, it clarifies expected behaviors about the assignment itself. As a grading tool, the rubric provides specific feedback to the students and indicates those areas in which they performed well and those that need improvement. As a business unit, the adoption of consistent rubrics encourages and reinforces department-level outcomes.

Units need to increase the communication to the students and public, in addition to the faculty, about assessment including the assessment goals, and especially, the results of assessment. The call for accountability is getting stronger as the economic situation in the United States worsens. Students are consumers of the education that business units provide and they 
want to ensure that they are getting a good quality education for the money they pay to the school. Communicating assessment results to the public and the students is one way that business units can show that they are working hard to provide high quality education. Communicating assessment goals and results with faculty is critical. Business units need to ensure that faculty clearly understand the learning outcomes and expectations of learning that relate to their classes. Additionally, should there be concerns identified in the assessment process, faculty need to be made aware of those areas to ensure that they make the necessary improvements in their classes and teaching. In this same manner, the assessment plans should also be updated to better reflect the assessments and goals and ensure clarity and understanding.

When planning assessment activities, teaching styles and learning styles should be considered. Shifting the focus from the teaching to the learning taking place in the classroom allows faculty to consider the learning styles, behavior, and individual characteristics of the learners and classes that they conduct and to plan the activities and assessments that will engage the students to the highest level possible.

Accreditation agencies should continue to examine assessment instruments and results for awarding or continuing accreditation. Because the business accreditors require regional accreditation as a prerequisite for specialized accreditation, additional relationships could be nurtured between regional accreditors and specialized agencies to standardize requirements for assessment. This would eliminate duplicate work on the unit level due to the differing reporting requirements and standards of the agencies.

\section{For Research}

Further research needs to be completed on assessments in accredited business schools. Research studies can determine changes and the increase/decrease in the baseline assessment 
activities presented in these findings. Given the economic climate at this time, additional research could also assess the cost and perceived benefits of assessment as some institutions may consider discontinuing their relationship with accreditors given the increasing costs of accreditation maintenance. An additional comparative analysis could also show the differences in accredited and unaccredited business units.

A related study could also investigate the accreditation agencies, their standards relating to assessment, how the assessment standards have changed over time, and the application or enforcement of those standards. This would be interesting to note the level of prescription that accreditation agencies have required over time as, while some accrediting agencies are becoming more prescriptive, business accreditors are shifting the focus from direct inputs to a more flexible format that involves the strategic use of assessment and improvement.

An in-depth analysis of instruments and assessment results would help clarify the level to which differences exist between specialized business accreditation agencies, for example the use of standardized tests like the Major Field Test in Business by ETS. A more focused qualitative analysis of the assessment instruments would allow more in-depth feedback on the instruments and uses. Specifically, an investigation into their contribution to the success of the business unit would be interesting given the unexpected lack of linear relationship between direct assessments and the students' ability to achieve passing grades.

Finally, additional demographical data could be analyzed to determine if there is a significant difference by demographic. For example, given that there is a perceived difference in the public accountability requirements for public and private institutions, it would be interesting to analyze the data to see if the differences were significant. There could also be a relationship 
between the size of the institution and the assessment activity, the regional accreditor and assessment, and other demographic differences.

\section{Summary}

This study gathered a wealth of information about accredited business schools. First, this research looked at assessment and accreditation in business schools, and then a review of the literature provided a framework for assessing the condition of assessment in accredited business schools. Next, the results of the research were analyzed and discussed. Finally, recommendations for research and practice were made.

A survey of accredited business schools found that, in general, business schools are following the best practices of assessment and using assessment to make a success of their units. The results of this study have the potential to provide benefits to schools that are seeking to improve their programs, those that are considering assessment or accreditation options, or those that wish to know the levels of assessment activity in business schools across the nation.

Although there are some significant differences in accreditation agencies, all of the agencies provide a means for their accredited units to meet higher quality standards and achieve success. This study is beneficial because of the lack of concise literature about assessment and accreditation in business schools, and especially the lack of any research that encompasses the three accrediting bodies for schools of business. 


\section{References}

Alstete, J. W. (2004). Accreditation matters: Achieving academic recognition and renewal. ASHE-ERIC Higher Education Report 30(4). Hoboken: Jossey-Bass.

American Association for Higher Education. (1992). Principles of good practice for assessing student learning. Washington, DC: Author.

Association of American Colleges and Universities. (2004). Our Students' Best Work: A Framework for Accountability Worthy of Our Mission. Washington, D. C.: Author. Association of Collegiate Business Schools and Programs. (2004a). About ACBSP. Retrieved September 18, 2004, from http://www.acbsp.org/vision.html

Association of Collegiate Business Schools and Programs. (2004b). ACBSP standards and criteria for demonstrating excellence in baccalaureate/graduate degree schools and programs. Overland Park, KS: Author.

Association of Collegiate Business Schools and Programs. (2006). Frequently asked questions. Retrieved October 10, 2006, from http://www.acbsp.org/index.php?mo=st\&op=ld\&sid=s1 020 acc \&stpg=25

Association to Advance Collegiate Schools of Business. (2002, August). Management education at risk report of the management education task force to the AACSB International Board of Directors. Tampa, FL: Author.

Association to Advance Collegiate Schools of Business. (2003). On the road to assessment. BizEd, 2(5), 30-32.

Association to Advance Collegiate Schools of Business. (2003). Sustaining scholarship in business schools: Report of the doctoral faculty commission to AACSB International's board of directors. St. Louis, MO: Author. 
Association to Advance Collegiate Schools of Business. (2004). About us. Retrieved September 18, 2004, from http://www.aacsb.edu/aboutus.asp

Association to Advance Collegiate Schools of Business. (2005). Eligibility procedures and accreditation standards for business accreditation. Tampa, FL: Author.

Association to Advance Collegiate Schools of Business. (2006). The AACSB guide to business education. Tampa, FL: Author.

Astin, A.W. (1991). Assessment for excellence: The philosophy and practice of assessment and evaluation in higher education. New York: Macmillan Publishing Company.

Baker, R. L. (2004) Keystones of regional accreditation: Intentions, outcomes, and sustainability. In Hernon, P. \& Dugan, R. E. (Eds), Outcomes assessment in higher education: Views and perspectives (pp. 1-16). Westport, CT: Libraries Unlimited.

Banta, T. W. (2005). How much have we learned? BizEd, 4(6), 34-38.

Banta, T. W., \& Associates. (Eds.), (2002). Building a scholarship of assessment. San Francisco, CA: Jossey-Bass.

Banta, T. W., Lund, J. P., Black, K. E., \& Oblander, F. W. (1996). Assessment in practice: Putting principles to work on college campuses. San Francisco, CA: Jossey-Bass.

Bennion, D. H. \& Harris, M. (2005) Creating an assessment culture at Eastern Michigan University: A decade of progress. Assessment update: Progress, trends, and practices in higher education, 17(2), 7-9.

Bloom B. S. (1956). Taxonomy of educational objectives, handbook I: The cognitive domain. New York: David McKay Co., Inc.

Bogue, E. G. (1998). Quality assurance in higher education: The evolution of systems and design ideals. In Gaither (Ed.), Quality assurance in higher education: An internal perspective. 
New Directions in Institutional Research:Vol. 99. (pp. 7-18). San Francisco, CA: JosseyBass.

Burgess, E. S., \& Shirley, S. W. (2004, September). Moving from good to great in institutions of higher learning: Will the learning outcomes assessment process help us get there? Paper presented at the Association of Collegiate Business Schools and Programs conference, Phoenix, AZ.

Council for Higher Education Accreditation. (1996). What is accreditation? [Electronic Version]. The CHEA Chronicle, 1(2).

Council for Higher Education Accreditation. (2002). Student outcomes learning workshop. [Electronic version]. The CHEA Chronicle, 5(2).

Council for Higher Education Accreditation. (2006a). Accrediting organizations in the U.S.: How they operate to assure quality. (Fact sheet \#5). Washington, D. C.: Author. Council for Higher Education Accreditation. (2006b). Database of institutions and programs accredited by recognized United States accrediting organizations. Retrieved September 26, 2006, from http://www.chea.org/search/default.asp

Council for Higher Education Accreditation. (2006c). Schedule for recognition reviews of accrediting organizations and call for third-party comment. Retrieved September 25, 2006, from: http://chea.org/recognition/RecogRev_Comment.asp

Creswell, J. W. (2003). Research design: Qualitative, quantitative, and mixed methods approaches $\left(2^{\text {nd }}\right.$ ed.). Thousand Oaks, CA: Sage Publications, Inc. 
Davenport, C. A. (2001). How frequently should accreditation standards change?, In Lubinescu et al (Eds.), How Accreditation Influences Assessment. New Directions for Higher Education: Vol. 113. (pp. 67-82). San Francisco, CA: Jossey-Bass.

Educational Testing Service (2006). Major field tests. Retrieved October 26, 2006, from http://www.ets.org/portal/site/ets/menuitem.1488512ecfd5b8849a77b13bc3921509/?vgne $\underline{\text { xtoid=f119af5e44df4010VgnVCM10000022f95190RCRD\&vgnextchannel=86f346f1674 }}$ f4010VgnVCM10000022f95190RCRD

Eldredge, D. L., \& Galloway, R. F. (1983). Study of undergraduate business policy course at AACSB-accredited universities. Strategic Management Journal, 4(1), 85-90.

Eaton, J. S. (2004, March). Balancing competing goods: Accreditation and information to the public about quality [Electronic version]. CHEA letter from the president. Washington, D. C.: Council for Higher Education Accreditation.

Eaton, J. S. (2005). The best in the world [Electronic Version]. Inside Accreditation with the President of CHEA. 1(2). Washington, D. C.: Council for Higher Education Accreditation.

Eaton, J. S. (2006). An Overview of U. S. Accreditation (revised). Washington, D. C.: Council for Higher Education Accreditation.

Ewell, P. T. (1993). The role of states and accreditors in shaping assessment practice. In T.W. Banta et al. (Eds.), Making a difference: Outcomes of a decade of assessment in higher education (pp. 339-356). San Francisco, CA: Jossey-Bass.

Ewell, P. T. (1998, June). Examining a brave new world: How accreditation might be different. Keynote address for the 2nd Council for Higher Education Accreditation "Usefulness" Conference, Washington, DC. 
Ewell, P. T. (2002). An emerging scholarship: A brief history of assessment. In T. W. Banta et al. (Eds.), Building a scholarship of assessment. (pp. 3-25). San Francisco, CA: JosseyBass.

Ewell, P. T. (2003). The Learning Curve. BizEd, 2(5), 28-33.

Fields, D. M. (2006). A Perfect Storm. BizEd, 5(2), 34-37.

Garvin, D. (1984). What does product quality really mean? Sloan Management Review, 26(1), 25-43.

Hagerty, B. M. K., \& Stark, J. S. (1989). Comparing educational accreditation standards in selected professional fields. Journal of Higher Education, 60(1), 1-20.

Harlow, L. L. (2005). The essence of multivariate thinking: Basic themes and methods. Mahwah, NJ: Lawrence Erlbaum Associates, Publishers.

Henninger, E. A. (1994). Outcomes assessment: The role of business school and program accrediting agencies. Journal of Education for Business, 69(5), 296-299.

Hernon, P. (2004). Selecting from the assessment tool chest. In Hernon, P. \& Dugan, R. E. (Eds), Outcomes assessment in higher education: Views and perspectives (pp. 149-170). Westport, CT: Libraries Unlimited.

Hernon, P., \& Dugan, R. E. (Eds.). (2004). Outcomes assessment in higher education: Views and perspectives. Westport, CT: Libraries Unlimited.

Huba, M. E., \& Freed, J. E. (2000). Learner-centered assessment on college campuses: Shifting the focus from teaching to learning. Boston, MA: Allyn \& Bacon.

Hubbard, R. G. (2006) Do not undervalue the impact of business education. In FT.com (The Financial Times). Retrieved June 28, 2006, from http://www.ft.com/cms/s/0af37f5006cc-11db-81d7-0000779e2340.html. 
Huber, M. T., \& Morreale, S. P. (2005). Situating the scholarship of teaching and learning: A cross-disciplinary conversation. [Electronic Version]. Introduction to disciplinary styles in the scholarship of teaching and learning: Exploring common ground. Washington, DC: American Association for Higher Education and The Carnegie Foundation for the Advancement of Teaching and Learning.

International Assembly for Collegiate Business Education. (2003). Accreditation manual: standard approach. Overland Park, KS: Author.

International Assembly for Collegiate Business Education. (2004). About IACBE. Retrieved September 18, 2004, from http://www.iacbe.org/

International Assembly for Collegiate Business Education. (2005). Accreditation process manual. Overland Park, KS: Author.

International Assembly for Collegiate Business Education. (2006). Membership. Retrieved October 10, 2006, from http://www.iacbe.org/

International Assembly for Collegiate Business Education. (2009, March). March 2009 Newsletter. Overland Park, KS: Author

Jones, E. A. (2002). Transforming the curriculum: Preparing students for a changing world (Monograph). ASHE-ERIC Higher Education Report, 29(3).

Jones, E. A. \& RiCharde, S. (2005). NEPC sourcebook on assessment: Definitions and assessment methods for communication, leadership, information literacy, quantitative reasoning and quantitative skills (Report No. NEPC 2005-0832). Washington, DC: National Postsecondary Education Cooperative. 
Krug, R. W. (2005, October). Analysis of the acceptance, characteristics and perceived efficacy of outcomes assessment programs at AACSB-accredited business schools. Paper presented at the Assessment Institute, Indianapolis, IN.

Lambert, D. \& Lines, D. (2000). Understanding assessment: Purposes, perceptions, practice. New York: Routledge-Falmer.

Leech, N. L., Barrett, K. C., \& Morgan, G. A. (2005). SPSS for intermediate statistics: Use and interpretation. Mahwah, NJ: Lawrence Erlbaum Associates, Publishers.

Locke, L. F., Silverman, S. J., \& Spirduso, W. W. (1998). Reading and understanding research. Thousand Oaks, CA: Sage Publications, Inc.

Lomax, R. G. (2001). Statistical concepts: A second course for education and the behavioral sciences. $\left(2^{\text {nd }}\right.$ ed.). Mahwah, NJ: Lawrence Earlbaum Associates, Inc. Publishers.

Lubinescu, E. S., Ratcliff, J. L., \& Gaffney, M. A. (2001). Two continuums collide: Accreditation and assessment. New Directions for Higher Education: Vol. 113. San Francisco: Jossey-Bass.

Lusher, A. L. (2006) Identifying Assessment Practices. Unpublished doctoral dissertation, West Virginia University, Morgantown.

MacTaggart, T. (2005). Quality assurance, accountability, and accreditation in collegiate business programs. Overland Park, KS: Association of Collegiate Business Schools and Programs.

Maki, P. L. (2002, January). Developing an Assessment Plan to Learn About Student Learning. Journal of Academic Librarianship, 28(1), 8-13.

Maki, P. L. (2004). Assessing for learning: Building a sustainable commitment across the institution. Sterling, VA: Stylus Publishing, LLC. 
McCoy, J. P., Chamberlain, D., \& Seay, R. (1994). The status and perceptions of university outcomes assessment in economics. Journal of Economic Education, 25(4), 358-366.

Michlitsch, J. A., \& Sidle, M. W. (2002). Assessing student learning outcomes: A comparative study of techniques used in business school disciplines. Journal of Education for Business, 77(3), 125-130.

Middle States Commission on Higher Education. (2005), Assessing student learning and institutional effectiveness: Understanding Middle States expectations. Philadelphia, PA: Author.

Mirchandani, D., Lynch, R., \& Hamilton, D. (2001). Using the major field test in business: Implications for assessment. Journal of Education for Business, 77(1), 51-56.

Palomba, C. A. (1997). Assessment at Ball State University. In Gray \& Banta (Eds.): CampusLevel Impact of Assessment Programs. New Directions for Higher Education: Vol. 100. (pp. 31-45). San Francisco, CA: Jossey-Bass.

Palomba, C. A. (2002). Scholarly assessment of student learning in them and general education. In T. W. Banta \& Associates, Building a scholarship of assessment (pp. 201-222). San Francisco: Jossey-Bass.

Palomba, C. A., \& Banta, T. W. (1999). Assessment essentials: Planning, implementing, and improving assessment in higher education. San Francisco: Jossey-Bass.

Palomba, N. A., \& Palomba, C. A. (2001). Assessment of student competence in business. In Palomba \& Banta (Eds.), Assessing student competence in accredited disciplines: Pioneering approaches in higher education (pp. 121-139). Sterling, VA: Stylus Publishing, LLC. 
Pike, G. R. (2002). Measurement issues in outcomes assessment. In T. W. Banta \& Associates, Building a Scholarship of Assessment (pp. 131-147). San Francisco: Jossey-Bass.

Pritchard, R. E., Potter, G. C, \& Saccucci, M. S. (2004). The selection of a business major: Elements influencing student choice and implications for outcomes assessment. Journal of Education for Business, 79(3), 152-156.

Rice, R. E. (2006). Enhancing the quality of teaching and learning: The U.S. experience. New Directions for Higher Education: Vol. 113. San Francisco: Jossey-Bass.

Sorensen, R. (2005). Thoughtful leadership. BizEd, 4(6), 46-49.

Sower, W. E. \& Fair, F. K. (2005). There is more to quality that continuous improvement: Listening to Plato. Quality Management Journal, 12(1), 8-20.

Suskie, L. A. (1996). Questionnaire Survey Research: What Works (2 ${ }^{\text {nd }}$ ed.). Tallahassee, FL: Association of Institutional Research.

Terenzini, P. T. (1997). Student outcomes information for policy-making: Final report of the national postsecondary education cooperative working group on student outcomes from a policy perspective. Washington, D. C.: National Postsecondary Education Cooperative and the National Center for Education Statistics.

U. S. Department of Education. National Center for Education Statistics (2002). Defining and Assessing Learning: Exploring Competency-Based Initiatives (Report No. NCES 2002159) Prepared by Jones, E. A. \& Voorhees, R., with Karen Paulson, for the Council of the National Postsecondary Education Cooperative Working Group on Competency-Based Initiatives. Washington, DC: Author.

U.S. Department of Education. National Center for Education Statistics. (2006a). The condition of education 2006. Washington, D. C.: Author. 
U. S. Department of Education. National Center for Education Statistics. (2006b). A test of leadership: Charting the future of U. S. higher education. Washington, D. C.: Author.

U. S. Department of Education. National Center for Education Statistics. (2008). Digest of education statistics: 2007. Washington, D. C.: Author.

Walker K. B., \& Black, E. L. (2000). Reengineering the undergraduate business core curriculum: Aligning business schools with business for improved performance. Business Process Management Journal, 6(3), 213.

Wergin, J. F. (2003). Departments that work. Bolton, MA: Anker.

Wright, B. D. (2002). Accreditation and the scholarship of assessment. In T. W. Banta et al. (Eds.), Building a Scholarship of Assessment (pp. 240-258). San Francisco: Jossey-Bass. 
APPENDIX A: SURVEY INSTRUMENT 
1. What year was your institution founded?

2. Is your institution 0 Public $O$ Private

3. What is your institution's single main focus?
O Research
O Teaching
Service
Other, indicate:

4. How many students attend your institution (total at all campuses)?

5. Is your institution regionally accredited? $O$ Yes $O$ No

6. If yes, please indicate which agency and date of most recent review (Month/Year).

C. Middle States Association of Colleges and Schools (MSA)

New England Association of Schools and Colleges Commission on Institutions of Higher Education (NEASC-CIHE)

C New England Association of Schools and Colleges Commission on Technical and Career Institutions (NEASC-CTCl)

C. North Central Association of Colleges and Schools Higher Learning Commission (NCA-HLC)

C Northwest Commission on Colleges and Universities (NWCCU)

r. Southern Association of Colleges and Schools (SACS)

C Western Association of Schools and Colleges Accrediting Commission for Community and Junior Colleges (WASC-ACCJC)

C. Western Association of Schools and Colleges Accrediting Commission for Senior Colleges and Universities (WASC-ACSCU)

7. To what degree is your institution mission reflected within the stated outcomes or assessment activities of your institution?
c. Very Clear
Somewhat Clear
Neither Clear nor Unclear
O Somewhat Unclear
O Not Clear at All

Academic Unit Demographics

8. Throughout the survey "academic unit" or "unit" is used to describe the academic business unit. What is your unit?
O College of Business
School of Business
O Department of Business
O Other
O No

9. Is your academic unit accredited by a specialized accreditation agency? . Yes

10. If yes, indicate your specialized accreditation(s), the date awarded (Month/Year), and the last review date (Month/Year).
D. AACSB
$\Gamma$ ACBSP
$\Gamma \mathrm{IACBE}$
T. Other
Date Awarded:
Date Awarded:
Date Awarded:
Date Awarded:
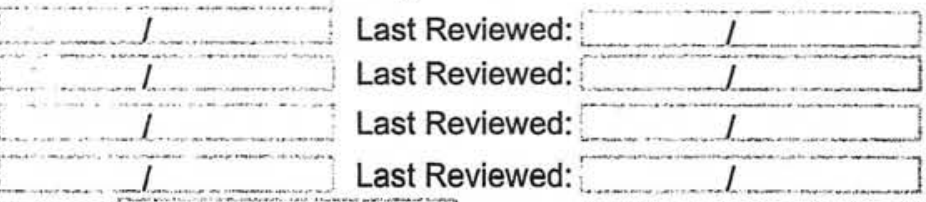

11. How many full-time faculty are there in your academic unit?

12. How many part-time faculty are there in your academic unit on average each semester?

13. How many students are currently enrolled in your academic unit?

14. On average, how many graduates per academic year does your academic unit award degrees in each level below?
Associate:
Bachelor:
Master:
Doctorate:

15. For each distinct degree listed below, please indicate the levels of education you offer in your unit. Please count only if it is an actual degree. For multiple majors within a general business degree - count as general business.

\begin{tabular}{|l|c|c|c|c|c|}
\hline Level and Degree Offered & Associate & Bachelor & Master & Doctorate \\
\hline Accounting & 0 & 0 & 0 & 0 \\
\hline Business Education & 0 & 0 & 0 & 0 \\
\hline Computer information/ Management Information Systems & 0 & 0 & 0 & 0 \\
\hline Economics/Managerial Economics & 0 & 0 & 0 & 0 & \\
\hline Finance (includes banking) & 0 & 0 & 0 & 0 \\
\hline General Business/Business Administration & 0 & 0 & 0 & 0 \\
\hline Management & 0 & 0 & 0 & 0 \\
\hline Marketing & 0 & 0 & 0 & 0 \\
\hline Other & 0 & 0 & 0 & 0 \\
\hline
\end{tabular}

16. For a general bachelor-level degree in Business/Business Administration, what majors do you offer? (Check all that apply.)
I. Accounting
[E-business/commerce
$\Gamma$ Finance (includes banking)
[I Insurance
Г. Marketing
[. Supply Chain Management/Logistics
[ Business Administration
ᄃ Computer Information Systems/MIS
Economics/Managerial Economics
Entrepreneurship/Small Business Admin
[] Hotel/Restaurant/Tourism
[. Human Resource Management
¿ International Business
$[$ Management
I. Production/Operations Management
Real Estate

17. To what degree is your unit mission reflected within the stated outcomes or assessment activities of your unit?
O Very Clear
6 Somewhat Clear
Neither Clear nor Unclear
Somewhat Unclear
Not Clear at All

This survey is confidential. Your name and institution will not be revealed. Please return this survey in the provided postage-paid envelope by April 27,2007 . Thank you for combletina this survev. 


\begin{tabular}{|c|c|c|c|c|c|}
\hline Assessment Commitment & $\begin{array}{c}\text { Strongly } \\
\text { Agree }\end{array}$ & Agree & Neutral & Disagree & $\begin{array}{l}\text { Strongly } \\
\text { Disagree }\end{array}$ \\
\hline 18. The administration at my institution is committed to assessment. & 0 & 0 & 0 & 0 & C \\
\hline 19. The administration of my academic unit is committed to assessment. & C & 6 & 0 & 0 & 0 \\
\hline 20. The faculty in my academic unit are committed to assessment. & c. & 0 & 0 & C. & 0 \\
\hline 21. Faculty are provided incentives to participate in assessment activities. & 0 & 6 & 6 & 0 & 0 \\
\hline 22. Faculty resist assessment efforts. & $\mathrm{C}$ & $\mathrm{O}$ & 0 & 0 & 6 \\
\hline Accreditation Commitment & $\begin{array}{c}\text { Strongly } \\
\text { Agree }\end{array}$ & Agree & Neutral & Disagree & $\begin{array}{l}\text { Strongly } \\
\text { Disagree }\end{array}$ \\
\hline 23. The administration at my institution is committed to accreditation. & 6 & O & 0 & 0 & $\mathrm{C}$ \\
\hline 24. The administration of my academic unit is committed to accreditation. & 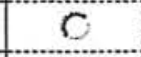 & 0 & C & 0 & C \\
\hline 25. The faculty in my academic unit are committed to accreditation. & 6 & 0 & 6 & C & C \\
\hline 26. Faculty are provided incentives to participate in accreditation activities. & 0 & O & $c$ & 0 & C \\
\hline 27. Faculty resist accreditation efforts. & 0 & 0 & C & 0 & O \\
\hline
\end{tabular}

28. Which of the following best describes your assessment plan and assessment efforts to date?
C No plan and not planning to create one
C. No plan but beginning to develop a plan
Planned but not implemented
Carly implementation stage with no assessment results
C. Beginning to review early assessment results
C. Reviewing results and beginning to formulate action plan
$r$ Implementing actions based on assessment results
Assessment plan is reviewed and changes have been made consistently to the plan over time

Answer the following questions concerning your assessment plan. If you do not have an assessment plan, go to question \#41.

\begin{tabular}{|l|c|c|c|c|c|c|}
\hline \multicolumn{1}{|c|}{ Select all that apply. } & $\begin{array}{l}\text { Faculty } \\
\text { Member }\end{array}$ & $\begin{array}{c}\text { Faculty } \\
\text { Committee }\end{array}$ & $\begin{array}{c}\text { Administrator } \\
\text { Administration } \\
\text { Committee }\end{array}$ & $\begin{array}{c}\text { Both Faculty \& } \\
\text { Administration }\end{array}$ & Other \\
\hline 29. Who developed your plan? & & & & \\
\hline 30. Who is responsible for your plan updates? & & & & \\
\hline $\begin{array}{l}\text { 31. Who is responsible for monitoring } \\
\text { assessment plan efforts? }\end{array}$ & & & & $\square$ & \\
\hline $\begin{array}{l}\text { 32. Who is responsible for reporting results } \\
\text { of assessment activities? }\end{array}$ & $\square$ & $\square$ & $\square$ & $\square$ & $\square$ \\
\hline
\end{tabular}

33. What was the largest single motivator in the creation of your assessment plan? (Please select only one.)
Regional aecreditation agency
Business unit decision
$O$ Institution policy or recommendation
C Specialized accreditation agency
O Faculty advocate
O Other, Indicate

34. Which of the following did you use to facilitate the development of your plan? (Please select all that apply.)
[ Institution guidelines
$\square$ Faculty expertise
$\square$ Regional accreditation outlines
$\Gamma$ External consuitants
$\square$ Internal consultants
T Specialized accreditation outlines

C. Other institution resources, please indicate

35. In what year did you begin to implement this plan?

36. In what year did you most recently update your plan?

\section{Assessment Details and Learning Outcomes}

\begin{tabular}{|c|c|c|c|c|c|c|}
\hline \multicolumn{2}{|c|}{ Revision Influences } & \multirow{2}{*}{$\frac{\text { very frequently }}{0}$} & \multirow{2}{*}{ often } & \multirow{2}{*}{ occasionally } & \multirow{2}{*}{$\frac{\text { rarely }}{0}$} & \multirow{2}{*}{$\frac{\text { never }}{0}$} \\
\hline 37. & $\begin{array}{l}\text { How often have you revised your assessment plan based on } \\
\text { recommendations from your specialized accreditation agency? }\end{array}$ & & & & & \\
\hline 38. & $\begin{array}{l}\text { How often have you revised your assessment plan based on } \\
\text { recommendations from your institution? }\end{array}$ & 0 & C & 0 & 0 & 0 \\
\hline 39. & $\begin{array}{l}\text { How often have you revised your assessment plan based on } \\
\text { recommendations from your own business school } \\
\text { colleagues? }\end{array}$ & 0 & $\mathrm{O}$ & $\mathrm{C}$ & $\mathrm{O}$ & 0 \\
\hline & $\begin{array}{l}\text { How often have you revised your assessment plan based on } \\
\text { recommendations from your own findings? }\end{array}$ & 0 & 0 & $\mathrm{O}$ & 0 & 0 \\
\hline
\end{tabular}

This survey is confidential. Your name and institution will not be revealed. Please return this survey in the provided postaae-Daid envelone hv Anril 27. 20n7. Thank vnı for rnmnlotinn thic cumsav 
41. How often do you use rubrics, or defined levels of performance, in assessment?
C. very frequently

often

often

occasionally

C.

rarely

rarely

never

C.

42A. During the past year, which direct assessment methods has your unit used with defined performance levels?

\begin{tabular}{|c|c|c|c|c|c|}
\hline & very frequently & often & occasionally & rarely & never \\
\hline Written Examinations (approximately 1 hour or more) & 0 & 0 & $c$ & $0^{-1}$ & O \\
\hline Quizzes (brief assessment, less than 1 hour) & 0 & 0 & 0 & 0 & 0 \\
\hline Commercially-developed exams (e.g. Major Field Tests) & O & 6 & 0 & 0 & 0 \\
\hline Oral Examinations & 6 & 0 & 0 & 0 & 0 \\
\hline Written Problems & 6 & 0 & 0 & 0 & 6 \\
\hline Thesis or Term Papers & 6 & C & 0 & 0 & 0 \\
\hline Projects & 0 & $\mathrm{O}$ & C & 0 & 6 \\
\hline Case Studies and Simulations & 0 & 0 & 0 & 0 & \% \\
\hline Presentations & C & 6 & 0 & 0 & 6 \\
\hline Portfolios & 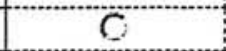 & 0 & $\mathrm{C}$ & 0 & 0 \\
\hline Internship or Practicum Evaluations & $\mathrm{O}$ & 0 & 0 & 0 & 0 \\
\hline Other: $\quad-\quad-\quad-1$ & 0 & 0 & 0 & 0 & 0 \\
\hline
\end{tabular}

42B. During the past year, which indirect assessment methods has your unit used with defined performance levels?

\begin{tabular}{|c|c|c|c|c|c|}
\hline & very frequently & often & occasionally & rarely & never \\
\hline Reflective Papers and Journals & 0 & 0 & 0 & 0 & 0 \\
\hline Entrance Interviews & 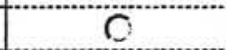 & 0 & 0 & 0 & 0 \\
\hline Exit Interviews & 0 & 0 & 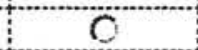 & 0 & 0 \\
\hline Focus Groups & 0 & 0 & 0 & 0 & 0 \\
\hline Employer Surveys & 0 & 0 & 0 & 0 & 0 \\
\hline Student Satisfaction Surveys & 0 & 0 & C & 0 & $\mathrm{C}$ \\
\hline Alumni Surveys & 0 & 0 & 0 & 0 & $\mathrm{C}$ \\
\hline Course Evaluations & 6 & 0 & 0 & 6 & 0 \\
\hline Other: $\quad-\quad-\quad$ & $\mathrm{C}$ & 0 & 0 & $\mathrm{O}$ & 0 \\
\hline
\end{tabular}

\section{Student Learning Outcomes and Assessment Practices}

43. The quality of teaching and learning is important on my campus.

44. The assessment efforts are a campus-wide initiative.

45. Assessment is part of my unit's culture, not just performed around accreditation, or another external motivator.

46. My unit provides incentives for faculty to participate in assessment efforts.

47. Assessment efforts measure items that are important and relevant to unit decisions.

48. The assessment plan in my unit has clearly stated goals.

49. Assessinent goals are shared with others.

50. The assessment plan provides clear, explicit student learning outcomes.

51. Objective measures and skill assessments are stated clearly in the plan.

52. Outcomes in my academic unit are connected to the academic unit's mission, vision, and goals.

53. Outcomes in my academic unit are connected to the institution's mission, vision, and goals.

54. Classes in my unit have outcomes developed because the unit faculty as a whole feels it is important, it is not an individual faculty effort.

55. Outcomes in my academic unit are learner-centered linked to significant aspects of learning and achievement.

56. Outcomes in my academic unit are focused on improving learners' knowledge.

57. Outcomes in my academic unit are clearly communicated to the learners.

58. Outcomes in my academic unit are developed by discipline collaboration.

59. My unit's assessment plan measures multiple learning objectives.

60. The assessment plan indicates the goals of individual assessment activities.

\begin{tabular}{|c|c|c|c|c|}
\hline $\begin{array}{c}\text { Strongly } \\
\text { Agree }\end{array}$ & Agree & Neutral & Disagree & \begin{tabular}{|l} 
Strongly \\
Disagree
\end{tabular} \\
\hline 0 & 0 & 0 & 0 & 5 \\
\hline 0 & 0 & 0 & 0 & 0 \\
\hline 0 & 0 & 0 & 0 & C \\
\hline 0 & 0 & 0 & 0 & 0 \\
\hline 0 & 0 & 0 & 0 & C \\
\hline 0 & 0 & 0 & 0 & C \\
\hline 0 & 0 & 0 & 0 & 0 \\
\hline 0 & 0 & 0 & 0 & C \\
\hline 0 & 0 & 0 & 0 & 0 \\
\hline 0 & 0 & 0 & 0 & 0 \\
\hline 0 & C & 0 & 0 & 0 \\
\hline 0 & $\mathrm{C}$ & $c$ & 0 & 0 \\
\hline 0 & 0 & 0 & 0 & C \\
\hline 0 & 0 & c & 0 & 0 \\
\hline 0 & 0 & 0 & 0 & $C$ \\
\hline 0 & 0 & 0 & 0 & $c$ \\
\hline 0 & 0 & 0 & 0 & 0 \\
\hline 0 & 0 & 0 & 0 & 0 \\
\hline
\end{tabular}

This survey is confidential. Your name and institution will not be revealed. Please return this survey in the

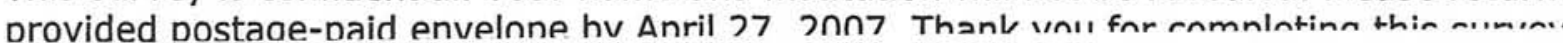




\begin{tabular}{|l|l|l|l|}
\hline Student Learning Outcomes and Assessment Practices (Continued) \\
\hline 61. Students are assessed at multiple points in their academic career. \\
\hline 62. Assessment is integrated across a "core" business curriculum. \\
\hline 63. The individual functional areas within the Business academic unit \\
(Accounting, Management, etc.) perform assessment.
\end{tabular}

81. How often does your institution currently use computer resources to monitor your assessment efforts?
C. Very Frequently
O Frequently
O Occasionally
C Rarely
C Never

82. If you use computer software, what type of package(s) do you use? (Check all that apply.)
$\Gamma$ Spreadsheet (Excel, etc)
T. Database (Access, etc)
$\Gamma$ Other software:

83. Where do faculty discuss assessment results? (Check all that apply.)
[ Faculty Offices
$\Gamma$ Regular Unit Meetings
[ Formal Retreats
¿ Other location:

84. What methods have you used to distribute your assessment results? (select all that apply)
$\Gamma$ Web Site $*$ Newsletter
ᄃ Bulletin Board
ᄃ. Presentation
5 Postal Mail
Other:

Assessment Success Indicators

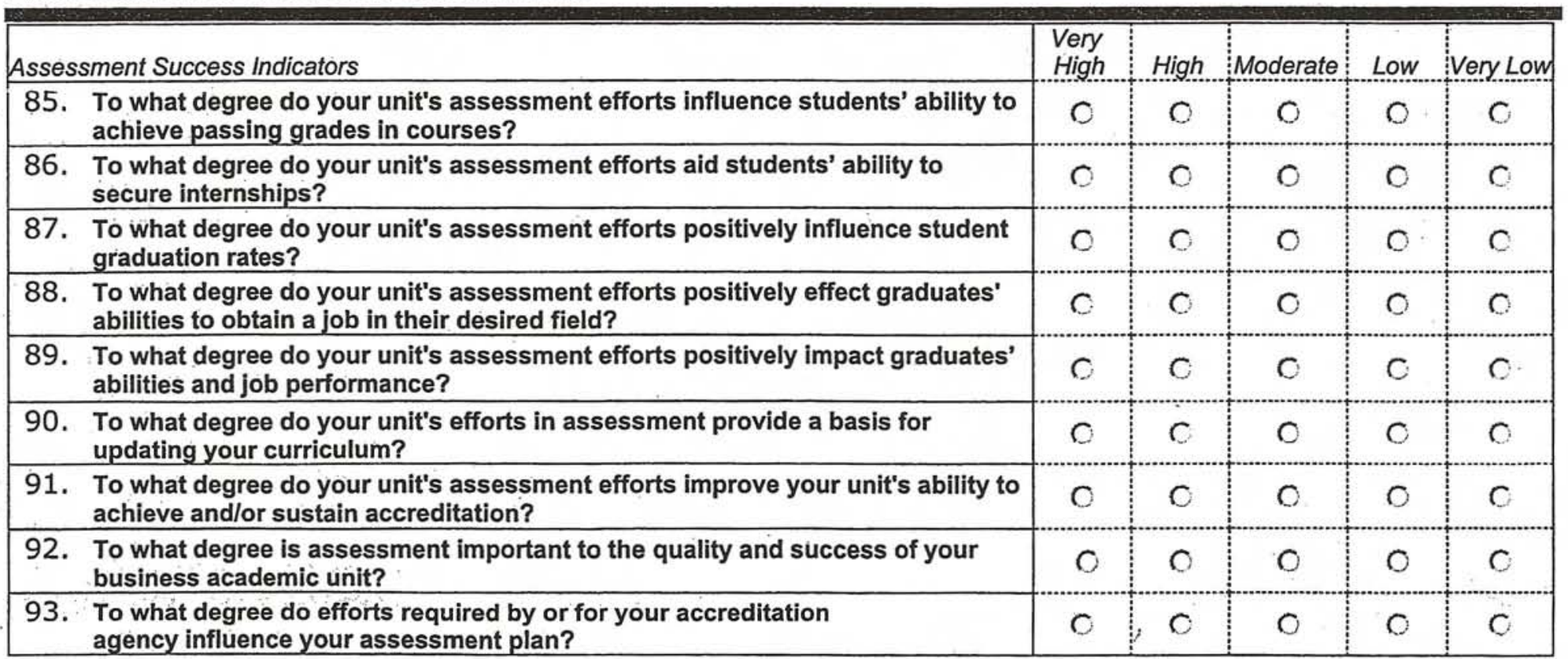


APPENDIX B: SAMPLE PILOT STUDY LETTER 


\section{West VirginiaUniversity}

College of Human Resources and Education

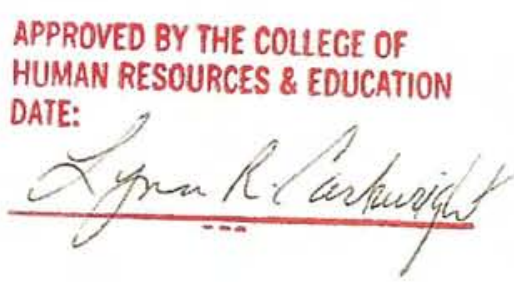

APPROVED BY THE COLLEGE OF HUTEN RESOURCES \& EDUCATION DATE:

Thank you for your willingness to participate in the pilot study examining assessment practices in accredited undergraduate business programs. This survey is part of a doctoral dissertation in Educational Leadership Studies at West Virginia University. The intent of this research is to survey all accredited undergraduate academic business units and determine the use of assessment and assessment practices.

You are one of five individuals participating in this pilot. Please read the cover letter as if you were participating in the actual study. Then, complete the Survey of the Examination of the Use of Assessment by Accredited Business Schools. Please keep track of how long it takes you to complete the entire survey and any problems you had while completing it. Feel free to make notes regarding any inconsistencies or problems that you find with the cover letter or any part of the survey instrument. You do not have to respond to every item on the survey, although your efforts to do so are appreciated. Your participation in this study is voluntary. West Virginia University's Institutional Review Board has approved this study and the survey instrument.

I would like to schedule a time with you to conduct a short interview before you return the survey so that you can share any suggestions that you might have for improvement. Your insight and suggestions will help me improve the survey instrument and the quality of data received. I will contact you via telephone or email within the next two weeks to schedule our brief conversation.

Please be assured that any information you provide will be used confidentially and anonymously, as no individual answers will be shared at any time. Again, thank you for taking the time to participate in this pilot study. If you have any questions, please feel free to contact me via phone at (304) 367-4191 or email at tdodson@fairmontstate.edu.

Sincerely,

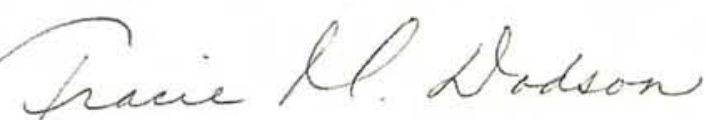

Tracie M. Dodson

WVU Doctoral Candidate 


\section{APPENDIX C: PILOT SURVEY INTERVIEW QUESTIONS}


Thank you for taking the time to complete the Survey of the Examination of the Use of Assessment by Accredited Business Schools. I would like to ask you a few questions about the survey to help strengthen it for the actual study. I have five questions about the cover letter and ten questions concerning the survey instrument.

\section{Cover Letter}

1. Was the cover letter easy to read and understand?

2. Was the purpose of the research clear in the cover letter?

3. Were you motivated to participate in the study after you read the cover letter?

4. Were the instructions for returning the survey clear?

5. Was there anything you feel should be added in the cover letter?

\section{Survey}

1. Were the instructions clear on the survey?

2. Was the wording clear and easy to understand?

3. Were there adequate answers for the questions?

4. Was the detail provided sufficient enough to answer the questions?

5. Were there any sections that you felt were difficult to answer?

6. Were there any questions that you feel were not relevant to the survey?

7. Were there any questions that you feel were missing from the instrument?

8. How long did it take you to complete the survey?

Did you feel that it was too long? Too short?

9. Did the organization of the survey make sense and flow smoothly?

10. Do you have any other suggestions for improvement?

Thank you for taking the time to complete the pilot study and speaking with me today. 
APPENDIX D: SAMPLE SURVEY COVER LETTER 


\section{WestVirginiaUniversity}

APPROVED BY THE COLLECE OF HUMAN RESOURCES \& EDUCATION DATE:

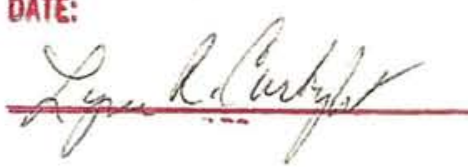

Enclosed you will find a brief survey on your assessment efforts and your accreditation status. This survey is part of a study examining assessment practices in accredited undergraduate business programs. Your survey answers will provide the basis of research findings for a doctoral dissertation in Educational Leadership Studies at West Virginia University. The intent of this research is to survey all accredited undergraduate academic business units and determine the use of assessment and assessment practices. Your participation is voluntary and West Virginia University's Institutional Review Board has approved this study and the survey instrument.

As you are aware, the assessment movement and the push to assess is very strong. Little research is being conducted to see the extent of the assessment efforts on campuses and the cumulative results of assessment. Accreditors, administrators, government agencies, and others say it is important to extend resources to assessment but few success stories are available to justify an ongoing assessment effort to already overburdened faculty. This study seeks to find what assessment initiatives are taking place, why they are taking place, and if the efforts are successful. In a time when management and business education are facing the challenges of globalization, economic uncertainties, ever-evolving technologies, and a changing student profile, it is important to have a clear understanding of student learning and the assessment activities that provide insight into that learning.

The survey contains four parts and should take you approximately $\underline{x}$ minutes to complete. You do not have to respond to every question in the survey, but your efforts to do so are appreciated. Once you have completed the survey, please return it in the addressed postagepaid envelope by to be determined. Please be assured that any information you provide will be used confidentially and anonymously as no individual responses will be shared at any time. Thank you for taking the time to participate in this study. If you have any questions, please feel free to contact me via phone at (304)367-4191 or email at tdodson@fairmontstate.edu.

Sincerely,

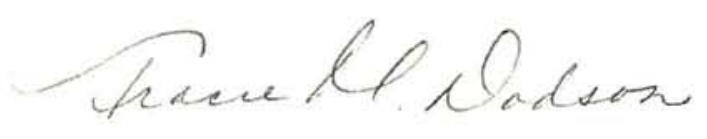

Tracie M. Dodson

WVU Doctoral Candidate

\author{
Educational Leadership Studies \\ 608 Allen Hall \\ PO Box 6122 \\ Morgantown, WV 26506-6122
}

Equal Opportunity/Affirmative Action Institution 